INDKOMSTPOLITIK KRISE STAT OG GENNEMSNITSPROFITRATE 


\section{KURASJE}

TIDSSKRIFT. Betingelser og priser for abonnement på tidsskriftet er anført på nummerets bagside.

Tidsskriftet udkommer med uregelmæssige mellemrum.

Abonnenterne bedes melde adresseforandring direkte til forlaget.

Abonnementsrækken nr. 13 til 16 omfatter mindst 500 sider.

BOGIMPORT. KURASJE er eneimportør for Skandinavien af bøger fra følgende tyske forlag: Association, Kübler, Maldoror, Merve, Olle \& Wolter, Politladen, Rosa Luxemburg Verlag, Rossa Verlag, Roter Stern, Trikont Verlag, Verlag Frauenoffensive, Verlag O og VSA samt det svenske forlag Röda Bokförlaget. Desuden er KURASJE eneimportør i Danmark af bøger fra Verlag Neue Kritik og Röda Bokförlaget. Der gives forhandlerrabat på bøgerne fra de nævnte forlag.

BOGHANDEL. I vores boghandel forhandles alle titler fra de nævnte forlag samt fra andre tyske og danske venstrefløjsforlag. Åbningstid: Mandag til fredag kl. 12.00 til 16.00.

FORLAG. KURASJE udgiver jævnligt bøger indenfor de to serier BIDRAG TIL KRITIK AF DEN mmer i august 1976.

I Sverige distribueres KURASJEs bøger gennem RÖDA BOKFÖRLAGET, Boks 7037, 40231 Göteborg.

Tidsskriftet KURASJE nr. 14

Sats og tryk: Special-Trykkeriet Viborg A/S

ISBN 87-87437-19-8

Rettigheder: KURASJE og de enkelte bidragsydere 


\section{TIDSSKRIFTETKURASJE Nr. 14

Redaktionen: Thomas Boje, Nils Bredsdorff, Jens Brinch, Carl-Ivar Carlin, Leif Hansen, Finn Hansson, Birgitte Harder, Tyge Kjær, Preben Kårsholm, Susanne Possing, Peter Søndergård og Olaf Winsløw.

Tidsskriftet behandler en lang række emner med det formål at bidrage til etableringen af en konkret formidlet kritik af det kapitalistiske system og det borgerlige samfund, og til diskussionen af overgangsformer til det kommunistiske samfund. Vi opfordrer interesserede til at indsende manuskripter især vedrørende følgende emner: analyse af den kapitalistiske akkumulations- og reproduktionsproces og dens kriser; analyser af arbejderbevægelsens historie, fagforeningsanalyser, klasseanalyser, kritik af reformismen; analyse af staten i det kapitalistiske samfund; analyse af verdensmarkedets udvikling og af tendensen til dannelsen af en verdenskapital; analyse af overgangsformer og overgangssamfundet.

Redaktionens adresse: Kurasje, Krystalgade 16, DK-1172 København K.

\section{INDHOLD}

Leder

Makoto Itoh: Udviklingen af den marxske kriseteori

Jürgen Hoffmann og Willi Semmler:

Kapitalreproduktion og indkomstpolitik

Et upubliceret Marx-manuskript om videnskab og kapital

65

Ole Fogh Kirkeby: Staten og dannelsen af gennemsnitsprofitraten

Susanne Possing: Kapitalbevægelse -

og klassebevægelse? 


\section{LEDER}

Indkomstpolitik synes i dag at være blevet den socialdemokratiske reformismes mana-ord: den besværgelse, der kan fjerne reformismens virkelige krise, nemlig den samtidige eksistens af arbejdsløshed og inflation. I denne besværgelsessammenhæng skal og må man foregøgle den danske fagog arbejderbevægelse, at en positiv sammenhæng også gælder negativt: når alle kan se, at lønniveauet generelt er vokset med beskæftigelsesgraden op gennem 1960'erne, må den nok også være sådan, at beskæftigelsesgraden kan bringes til at vokse på bekostning af lønniveauet. Her får reformismen st $\varnothing t t e$ af enkelte socialistiske $\varnothing$ konomer, som i hvert fald tidligere også betragtede lønniveau som bestemmende for beskæftigelsesniveau. Vi har tidligere både her og i flere artikler vist, at denne antagelse er forkert, bl.a. fordi den bygger på en implicit antagelse om lønnen som kriseårsag, resp. lønniveauet som arbejdsløshedens årsag.

Antagelsen om at et lavere lønniveau vil føre til et højere beskæftigelsesniveau er dog også blevet gjort ugyldig af udviklingen i det sidste 1-1 1 1/2 år. Med overenskomstindgrebet i 1975 fremkaldtes en stagnation i lønudviklingen, hvis resultat i beskæftigelsesmæssig forstand indtil dato i bedste fald har været at stabilisere arbejdsløsheden på et permanent højt niveau: ca. $9 \%$ på årsbasis.

Selv om man således kan afvise indkomstpolitikkens direkte beskæftigelsesmæssige virkninger, kan den måske få beskæftigelsesmæssige virkninger på lidt længere sigt. Det forudsætter dog, at indkomstpolitikkens fordelingsmæssige rationale også gennemføres, nemlig omfordelingen fra løn til profit. Det er indlysende, at enhver form for opbremsning i lønudviklingen vil virke i retning af at omfordele fra løn til profit. Når og hvis denne omfordeling er stor nok til at genskabe bedre rentabilitetsforhold for den investerede kapital af en sådan størrelsesorden, at et nyt akkumulationsboom starter, vil beskæftigelsen kunne vokse igen.

Gennemføres der en omfordeling mellem løn og profit via indkomstpolitiske foranstaltninger, må man selvfølgelig også spørge, hvilke kapitaler, der får størst gavn af denne omfordeling. Her er det nok således, at indkomstpolitikkens omfordeling har størst betydning for de tilbagestående kapitaler; kapitaler, hvis produktivitetsudvikling er dårligere end gennemsnittet og som følgelig ikke kan foretage omfordelingen selv gennem de produktivitetsbundne lønsystemer. Derfor forekommer det rimeligt at antage, at indkomstpolitisk lønbegrænsning i sin tendens vil fastfryse den eksisterende kapitalstruktur.

Når vi her taler om indkomstpolitik, mener vi en direkte statslig løn- eller lønrammefastlæggelse, dvs. kun de ydre statslige tvangsindgreb. Vi betragter ikke de mange politikformer, der iøvrigt har fordelingsmæssige følger som 
indkomstpolitik. Afgrænset på denne måde, kan man sige, at indkomstpolitik i Danmark kun har været nødvendig som en undtagelsesform - så meget undtagelse, at den kun forekommer i 1963 og 1975, eller to gange i efterkrigstiden.

Ønsket om i dag at få indført en moderne indkomstpolitik deles af mange forskellige politiske kræfter, selv om deres motiver antagelig er vidt forskellige. At indkomstpolitikken skal betragtes som en direkte lønkontrol kan vist kun være en hemmelighed for de mest naive og trofaste socialdemokratiske $\varnothing$ konomer. Dermed er dog ikke sagt, at denne lønkontrol skal udøves alene i form af en ydre statslig lønfastlæggelse. For den progressive populistiske del af socialdemokratiet gælder det omvendte nærmest. Her vil man snarere søge at modernisere arbejsmarkedspolitikken, hvorved man når frem til en langt mere ugennemsigtig styring med langt større mulighed for at videreudvikle den særlige indkomstpolitikform, som har været den dominerende i Skandinavien i efterkrigstiden.

I deres analyse fastlægger Semmler og Hoffmann indkomstpolitik som en ydre statslig lønfastlæggelse og afgrænser dens former efter indgrebets art og akkumulationsprocessens udviklingstrin. Dette giver en grundig og inspirerende analyse af visse teoretiske aspekter af indkomstpolitikken og af fællestræk for den vesteuropæiske akkumulationsbevægelse som sådan. I deres opdeling henhører den skandinaviske indkomstpolitik under den form, som er baseret på en veludviklet magtposition for fagbevægelsen, da den fastfryser udbytningsforholdet gennem binding af lønudviklingen til produktivitets- og prisudvikling. Det betyder, at betingelsen for en forøgelse af udbytningsforholdet - eller for en forøgelse af den profit, som kapitalerne kan tilegne sig - er at produktivitetsudviklingen foregår hurtigere end lønudviklingen. I den skandinaviske udformning foregår denne proces generelt uden ydre statsindgreb, dvs. at indkomstpolitikkens resultater i en vis udstrækning opnås uden de former, som er karakteristiske for udviklingen i Vesteuropa generelt. Til gengæld foregår der en lønstyring, gennemført af en fagbevægelse og et statsapparat, der formulerer sig helt og holdent inden for en socialdemokratisk integrationsforståelse?

Det særlige ved den skandinaviske indkomstpolitikform er som nævnt at de direkte statslige tvangsindgreb overfor løndannelsen er overflødige på nær enkelte undtagelser. Til gengæld findes der en veludviklet indirekte lønstyring gennem den arbejdsmarkedsregulering, som socialpartnerne kapital og arbejde gennemfører i et udstrakt samarbejde med staten. Her kan især Sverige tjene som eksempel. Følgende punkter er værd at notere sig:

- lønforhandlingerne er i meget høj grad centraliserede, sammenlignet med forholdene i Vesteuropa generelt

- der er »fredspligt« i overenskomstperioden, hvilket betyder, at de relativt få strejker er aftalemæssigt kriminaliserede.

- fagforeningerne fører indadtil en såkaldt solidarisk lønpolitik, hvilket i nogen grad forhindrer løntryk fra andre faggrupper. Dermed frem- 
mes tendentielt en lønudligning, mest markant mellem mands- og kvindelønninger

- fagforeningerne fører udadtil en lønpolitik, hvor lønnen bindes til produktivitetsudviklingen. Resultatet er for Danmarks vedkommende at reallønnen ganske vist vokser, men at væksten sker i spring samtidig med at den er langt mindre end i f.eks. Vesttyskland

- for Sverige gælder tydeligvis, at det vigtigste erklærede mål for den statslige konjunkturregulering er den fulde beskæftigelse. Midlerne er legio, men vigtige i denne sammenhæng er arbejdsmarkedspolitikkens mobilitetsmekanismer, der fremmer såvel faglig som geografisk mobilitet. Det betyder også, at man på politisk plan kan acceptere højere inflationsrater end en del andre socialdemokratier

Disse strukturelementer, som her kun kan opregnes og ikke begrundes nærmere, har for den danske industris vedkommende skabt en reallønsudvikling, der lige siden 1966 lå under samme industris produktivitetsudvikling. For Sveriges vedkommende er udviklingen endnu mere grel: stigningstakten i den industrielle produktivitet har ligget systematisk over stigningen i reallønnen uden undtagelser i perioden 1950 til 1970. ${ }^{1}$

Hvorfor skal indkomstpolitikken moderniseres og søge en mere permanent styring? Det skal den fordi den trods alle reformistiske illusioner, stadig viser sig at være nødvendig, nemlig i de perioder, hvor den traditionelle arbejdsmarkedspolitik ikke kan garantere, at reallønsudviklingen kan holdes under produktivitetsudviklingen. Indgrebene i 1963 og 1975 synes begge at pege i denne retning. Tvangsindgreb bliver nødvendige ud fra to udviklingstendenser:

1. når reallønnen vokser hurtigere end produktiviteten og

2. når reallønnens vækst især fremkommer gennem de ukontrollable faktorer, dvs. gennem lønglidning

Med disse betragtninger har vi ønsket at pege på enkelte af de specifikke forudsætninger, som en videreudvikling af Semmler/Hoffmanns generelle analyse af indkomstpolitikkens virkninger på kapitalakkumulationen vil kræve indarbejdet. Gennem indarbejdelse af disse forudsætninger, som alle omhandler den nationale politiske tradition - dvs. den udviklede socialdemokratiske reformisme - vil analysen af forholdet mellem politik og økonomi også kunne videreudvikles.

1. For Sveriges vedkommende, se E. H. Phelps-Brown: Levels and Movements of Industrial Productivity and Real Wages.

Internationally Compared, 1860-1970, i: The Economic Journal, March 1973, s. 58-71.

For Danmarks vedkommende ligger følgende opgørelser til grund for de angivne sammenhænge: 


\begin{tabular}{|c|c|c|c|c|}
\hline & \multicolumn{2}{|c|}{ Indeks for udviklingen i } & \multicolumn{2}{|c|}{ Procentvis stigning pr. år $\mathrm{i}$} \\
\hline & Realløn & Produktivitet & Realløn & Produktivitet \\
\hline 1959 ...................... & 80 & 76 & & \\
\hline 1960 ………........ & 82 & 79 & 2,5 & 3,4 \\
\hline 1961 ……............. & 85 & 84 & 3,6 & 6,4 \\
\hline $1962 \ldots \ldots \ldots \ldots \ldots . .$. & 92 & 88 & 8,1 & 5,7 \\
\hline 1963 ....................... & 96 & 92 & 4,3 & 3,9 \\
\hline 1964 ..................... & 100 & 100 & 4,3 & 9,1 \\
\hline 1965 ..................... & 106 & 106 & 5,9 & 6,3 \\
\hline 1966 ..................... & 114 & 113 & 7,6 & 6,1 \\
\hline 1967 ....................... & 122 & 125 & 7,1 & 10,8 \\
\hline $1968 \ldots \ldots \ldots \ldots \ldots . . .$. & 132 & 138 & 8,2 & 10,4 \\
\hline 1969 ........................ & 136 & 151 & 3,0 & 9,3 \\
\hline 1970 .................... & 145 & 155 & 6,8 & 2,7 \\
\hline 1971 ……............ & 154 & 167 & 6,1 & 8,1 \\
\hline 1972 ……............. & 164 & 181 & 6,6 & 8,4 \\
\hline 1973. & 179 & 197 & 9,1 & 8,8 \\
\hline
\end{tabular}

Anm. Reallønnen er opgjort som nominel timeløn i industri og håndværk, deflateret med forbrugerprisindekset $(1964=100)$. Produktiviteten er opgjort som stigningen i industriens bruttofaktorindkomst pr. præsteret arbejdstime.

Kilde: Statistisk Tiårsoversigt, div. år og Jens Brinch: Kapitalakkumulation i Danmark efter 1940 II, Kbh. 1975 s. 119.

\section{Får De trykt}

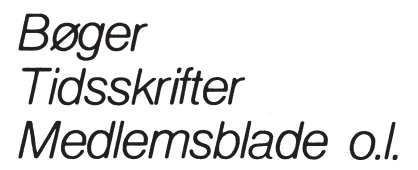

var det måske en ide at spørge os. Vi har den helt rigtige teknik til at dække enhver opgave, så den bliver fremstillet på den billigste og mest hensigtsmæssige måde.

SPECIAL-TRYKKERIET VIBORG a-s

Gørtlervej 7 . Telf (06) 624033 . 8800 Viborg

OFFSET - FOTOSATS - REPRO 


\section{Subskriptionstilbud:}

\section{Die Linke Opposition in der Sowjetunion Tekster fra perioden 1923-28 Udgivet og indledt af Ulf Wolter}

Bidrag bl.a. af: Bucharin, Bubnow, Joffe, Kamenew, Krupskaja, Ossinskij, Pjatakow, Preobraschenskij, Radek, Rakowski, Rykow, Sapnorow, Sereriakow, Sinowjew, Sokolnikow, Smirnow, Stalin, Tomski, Trotzki.

4 bind på 500 til 600 sider hver.

Udsalgspris: ca. $75,00 \mathrm{kr}$. pr. bind.

Ved subskribtion på alle 4 bind er prisen kr. 60,00 pr. bind.

Man tegner subskribtion ved at indbetale kr. 60,00 på giro 7166044 . Herefter fremsendes bøgerne som de udkommer med en opkrævning ved hvert af de tre første bind, mens det fjerde tilsendes uden opkrævning. Bind II, der omhandler perioden 1924-25 er udkommet, de øvrige bind udkommer i anden halvdel af 1976.

\section{Billige tilbud:}

\section{Werner T. Angress:}

Stillborn Revolution

Die Kampfzeit der KPD 1921-1923

547 sider; kr. 49,90.

\section{Uwe Brügmann:}

Die russischen Gewerkschaften in

Revolution und

Bürgerkrieg 1917-1919

285 sider; kr. $27,70$.
Horst Duhnke:

Die KPD von 1933 bis 1945.

604 sider; kr. 55,45.

Karl Korsch:

Politische Texte

400 sider; kr. 41,55.

Victor Serge:

Erinnerung eines Revolutionäres 1901-1941

542 sider; kr. 38,80.

Bestilling ved indbetaling af de anførte priser på giro eller ved check.

KURASJES BOGIMPORT er eneimportør af bøger fra følgende vesttyske forlag: Association, Kübler Verlag, Maldoror, Merve Verlag, Neue Kritik, Olle \& Wolter, Politladen, Rosa Luxemburg Verlag, Rossa Verlag, Roter Stern, Trikont Verlag, Verlag Frauenoffensive, Verlag $\mathrm{O}$ og Verlag für das Studium der Arbeiterbewegung (VSA).

Bestil kataloger!

\section{KURASJES BOGIMPORT}

Krystalgade 16, 1172 København K, giro: 7166044 


\section{UDVIKLINGEN AF DEN MARXSKE KRISETEORI*}

Makoto Itoh

\section{To typer af kriseteori}

Marx’s kriseteori i »Kapitalen« udgør et knudepunkt i hans systematiske kritik af den klassiske økonomi, hvor det kapitalistiske økonomiske system betragtes som den endelige naturlige organisering af det menneskelige samfund. I modsætning til den klassiske skole behandler Marx's teori lovmæssighederne for den kapitalistiske produktionsmåde med dens historiske former og mekanismer på en videnskabelig måde. Uden en sådan systematisk teori kan vi ikke klarg $\varnothing-$ re den logiske nødvendighed af de cykliske kriser, som afslører kapitalismens modsigelsesfulde natur $\mathrm{i}$ alle dens komplekse relationer.

Når man beskæftiger sig med disse komplekse fænomener er abstraktionsniveauet og dets empiriske basis særlig vigtigt. Kriseteorien i »Kapitalen« blev udviklet for at bevise uundgåeligheden af cykliske kriser på et grundlæggende principielt niveau. Og den blev skabt med empiriske basis i de mest typiske cykliske kriser i midten af det 19. århundrede, det mest ideelle historiske grundlag for at foretage en abstrakt bestemmelse af krisens væsen.

Hvis vi som grundlag for abstraktionerne ikke for at bevise den simple mulighed, men den logiske nødvendighed af cykliske kriser, inddrager krisernes sam-

* Oversættelse af: Makoto Itoh: The Formation of Marx's Theory of Crisis, i: Bulletin of the Conference of Socialist Economist, February 1975 (Vol. IV 1). 
lede historie, indbefattet de uudviklede kriser i den merkantilistiske periode, vil vi kun opdage enten alt for forskellige konkrete faktorer (ofte ikke kun økonomiske faktorer, men f.eks. krige), som påvirker krisernes forløb og faser eller alt for abstrakte fælles faktorer. Her er Professor Uno's systematiske skelnen mellem forskningsniveauer i den marxske $\varnothing$ konomi mellem principper, faseteori og analyse væsentlig. Unders $\varnothing$ gelse af de historiske forandringer i de $\varnothing$ konomiske krisers rolle og faser igennem kapitalismens verdenshistorie, som omfatter tre stadier, nemlig merkantilisme, liberalisme og imperialisme, burde snarere foretages på et andet og højere forskningsniveau som faseteorien end den politiske $\varnothing$ konomis grundprincipper, som vi ser dem i »Kapitalen «'s teoretiske system. Jo mere sikkert krisens princip bliver, desto mere bestemt kan faseteorien om kriserne gøres, og desto mere sikkert kan den nuværende kapitalismes kritiske situation endvidere analyseres. Selv i vor tid må vi anerkende betydningen af Marx' kriseteori, der er abstraheret fra de typiske cykliske kriser i midten af det 19. århundrede som de kapitalistiske krisers princip.

Marx's kriseteori er imidlertid ikke komplet. Den indeholder mere præcist to typer af teori, som ikke uden besvær kan gøres overensstemmende med hinanden. Lad os kort og godt kalde dem »overakkumulationsteorien« og »overproduktionsteorien «.

For eksempel forsøger Marx i del 3 af kapitel 15 i tredje bind af »Kapitalen« at vise, at »et stærkt og pludseligt fald i den almene profitrate « på grund af »absolut overproduktion af kapital « »i forhold til den arbejdende befolkning « (K. III. S. 262, p. 331) ${ }^{1}$ frembringer cykliske kriser. I denne sammenhæng betragtes tilstedeværelsen af et vareoverskud på markedet og vanskelighederne med at realisere merværdien som et resultat af den faldende profitrate som skyldes overakkumulation af kapital. ${ }^{2}$ Marx's fors $\varnothing \mathrm{g}$ på i »Kapitalen « at udvikle teorien om den industrielle cyklus med dette udgangspunkt kan også ses i hans teori om kapitalakkumulationen i første bind (K.I, s. 641-49, 661, p. 864-76, 890 - 91) og i hans kreditteori i tredje bind (K. III, s. 529-30, p. 673-74). »Betingelserne for

1. I denne artikel citeres følgende værker: »Das Kapital«, Marx Engels Werke (MEW), 23-25, »Grundrisse der Kritik der politischen Ökonomie«, Europäische Verlagsanstalt, Frankfurt, »Theorien über den Mehrwert «, MEW 26.1. og 26.2. Ved oversættelsen er anvendt den danske Rhodos-udgave af »Kapitalen« samt Modtryk - Kurasjes oversættelse af »Grundrids«. Hvor teksterne ikke er udkommet på dansk er oversættelsen foretaget efter den tyske MEW. Sideangivelsen: $s$ henfører til den tyske udgave, hvorimod $p$ henviser til de omtalte danske oversættelser. (Overs. anm.)

2. P. M. Sweezy kalder denne type teori for »Kriser, som er ledsaget af profitratens faldende tendens« $\mathrm{i}$ hans »Theory of Capitalist Development (1942). Som jeg senere vil komme ind på bør denne teori udvikles temmelig uafhængig af »loven om profitratens faldende tendens «. Sweezys betegnelse synes her at være vildledende. Hans behandling af denne teori forbliver imidlertid (sammen med Professor Kouzo Unos og hans efterfølgeres studier i Japan) en af de sjældne fremstillinger i den Marxske kriseteoris histories. Jeg vil også foreslå at det navn Sweezy giver den anden teoritype »realiseringskrise $\ll$ - forandres for at tydeliggøre modsætningen til denne teori. 
den umiddelbare udbytning og dens realisation er ikke identiske... Den første er kun begrænset af samfundets produktionskapacitet, den anden af proportionaliteten mellem de forskellige produktionsgrene og af samfundets konsumtionskraft «. I takt med den voksende produktion af merværdi« forstærkes... modsigelsen mellem de betingelser, hvorunder denne merværdi produceres, og de betingelser, hvorunder den realiseres.« (K. III, s. 254-55, p. 322-323).

Også i kapitel $30 \mathrm{i}$ bind III understreger Marx at »misforholdet mellem produktionens forskellige grene $\ll$ og »massernes armod og konsumtionsbegrænsning « overfor udviklingen af produktivkræfterne er den egentlige årsag til kriserne (K. III, s. 501, p. 636-37). På disse steder mener han at kriserne opstår på grund af en overproduktion af varer i forhold til efterspørgslen, hvilket skyldes enten disproportionaliteten mellem produktionsgrenene eller massernes begrænsede konsumtion. Overakkumulationen af kapital og profitratens fald betragtes som resultater af denne proces.

Det er unødvendigt at påpege, at såvel kapital som varer generelt bliver overskydende i kriseperioder. Men det er vigtigt at udskille hvilken af dem, der er den grundlæggende årsag til de økonomiske kriser. Overakkumulationsteorien og overproduktionsteorien står logisk set i modsætning til hinanden på dette punkt. Det er ikke muligt at opretholde begge teorier, hvis man søger at vise den logiske nødvendighed af $\varnothing$ konomiske kriser i den politiske $\varnothing$ konomis principper.

Hvorfor eksisterer disse to modstridende teorier ved siden af hinanden $\mathrm{i}$ $»$ Kapitalen «? I hvilken retning og hvordan skal Marx's kriseteori udbygges? Jeg vil forsøge at besvare disse spørgsmål ved at se tilbage på udviklingen af Marx's kriseteori fra »Grundrids« til »Kapitalen«.

\section{Kriseteorien i »Grundrids«}

$\mathrm{I} »$ Kapitlet om kapitalen« $\mathrm{i} »$ Grundrids «, som er det første manuskript til »Kapitalen« fra 1857-58, viser Marx sine teoretiske studier af kriserne, især i begyndelsen af del II »Kapitalens cirkulationsproces« og i forbindelse med profitteorien i del III, »Kapitalen som frugtbringende«.

I begyndelsen af del II af »Grundrids« behandler Marx varesalgsprocessen, dvs. V'-P', som en vigtig begrænsning af kapitalens bevægelser i modsætning til fremstillingen i andet bind af »Kapitalen«. Et eksempel:

»Det glemmes, at - som Malthus siger - »hele eksistensen af en profit på en eller anden vare forudsætter en efterspфrgsel, der er ydre i forhold til den arbejder, som har produceret den « og derfor kan arbejderens egen efterspфrgsel aldrig vare en adaekvat efterspфrgsel. Da én produktion sætter den anden i bevægelse og derfor skaffer sig konsumenter i den fremmede kapitals arbejdere, så fremtraeder for enhver kapital arbejderklassens efterspørgsel, der selv er sat gennem produktionen, som »adækvat ef- 
terspørgsel«. Denne gennem produktionen selv satte efterspørgsel driver på den ene side produktionen ud over den proportion, hvori den skulle producere i relation til arbejderne; (den) må drive den ud over denne (proportion); på den anden side: hvis efterspørgselen, der er ydre i forhold til arbejderen selv, forsvinder eller skrumper sammen, så indtræder sammenbruddet.«(Gr. s. 323, p. 303) ${ }^{3}$

Marx forudsætter her at kapitalistisk vareproduktion i sin helhed nødvendigvis må overstige de rette proportioner i forhold til konsumenternes efterspørgsel og understreger at $\gg$ det endelige produkt finder sin grænse ved det umiddelbare og endelige konsum. (Gr. s. 323, p. 304). Det bør bemærkes at Marx endnu ikke klart diskuterer den logiske nødvendighed af kriser i cyklisk form. Han fastholder i »Grundrids « snarere, at de økonomiske kriser næsten er det samme som eller direkte leder til den kapitalistiske produktionsmådes endelige sammenbrug, hvilket han baserer på overproduktions/underkonsumtionsteorien.

Øjensynlig forsøger Marx her at efterfølge og udvikle Sismondis og Malthus' kriseteori, som stod i modsætning til Ricardos klassiske teori. Marx stiller Sismondi overfor Ricardo på følgende måde:

»De økonomer, der som Ricardo opfatter produktionen som umiddelbart identisk med kapitalens selvværdiøgning... - de har derfor fattet kapitalens positive væsen rigtigere og dybere end de ( $\varnothing \mathrm{ko}-$ nomer), der som Sismondi betoner skrankerne for konsumtionen og for den forhåndenværende kreds af mod-værdier, omend den sidste dybere har begrebet bornertheden og den negative ensidighed ved den på kapitalen baserede produktion. Den første (gruppe af økonomer) mere dens universelle tendens, den anden (gruppe dens) særegne indskrænkethed.«(Gr. s. 314, p. 295).

Det er korrekt at Malthus og Sismondi forsøgte at vise uundgåeligheden af almindelig overproduktion, og derfor den kapitalistiske produktionsmådes særlige indskrænkethed, hvorimod $\varnothing$ konomer som Ricardo ensidigt betonede tilpasningen mellem udbud og efterspørgsel på basis af værdiloven, idet de benægtede muligheden af en generel overproduktion af varer. Ifølge den klassiske økonomis arbejdsværdilov bliver værdien af den årlige vareproduktion totalt set altid identisk med revenuerne, dvs. lønnen, profitten og renten, som er nødvendige til at købe den, fordi begge er bestemt at det totale kvantum samfundsmæssigt arbejde pr. år. En udvidelse af den kapitalistiske produktions omfang udvider både udbuddet og efterspørgslen efter varer værdimæssigt helt tilsvarende. Sismondi og Malthus gik imod denne teori ved i virkeligheden at kaste arbejdsværditeorien over bord, idet de hævdede, at de forskellige former for revenuer udsprang uafhængigt af kapital, arbejde eller jord, og ud fra dette synspunkt stillede de spørgsmålstegn ved antagelsen om, at summen af disse revenuer skulle være tilstrækkelig til at købe det totale udbud af det årlige arbejdsprodukt. Her bliver det sociale forhold mellem produktion og konsumtion, eller udbud og efterspørgsel adskilt fra deres indre sammenhæng med det samfundsmæssige arbejde, og kun deres ydre ligevægt på cirkulationens overflade betvivles.

3. Denne forkortelse henviser herefter til sider i Karl Marx, »Grundrisse der Kritik der Politischen Ökonomie«, 1953, og den danske oversættelse fra Grundrids, 1975. 
Ud fra dette synspunkt sagde Malthus, »Hvis produktionen er meget større end konsumtionen, så må akkumulations- og produktionsmotivet forsvinde på grund af et $\varnothing$ nske om effektiv efterspørgsel hos dem som er i besiddelse af de væsentlige købemidler « ${ }^{4}$ og han fastholdt at denne vanskelighed kunne overvindes ved hjælp af bl.a. jordejernes uproduktive efterspørgsel. ${ }^{5}$ Sismondi forfægtede en underkonsumtionsteori på et lidt tidligere tidspunkt og på en noget mere skarp måde end Malthus. Hos ham forårsager kapitalakkumulationen på den ene side en formindskelse af konsumefterspørgslen på grund af, at både arbejdere (og bønder) erstattes af maskiner i forbindelse med produktionens centralisering. På den anden side forårsager den også en voksende mængde varer uden hensyn til efterspørgselsniveauet. ${ }^{6}$ Som følge deraf må »overfloden af produktion, som overstiger konsumtionen $\ll^{7}$ indtræffe. ${ }^{8}$

For at klargøre den kapitalistiske produktionsmådes bornerthed og uundgåeligheden af en almindelig overproduktion, hvilket blev ignoreret af de klassiske $\varnothing$ konomer, fremhæver Marx, idet han følger Malthus' og Sismondis linie op, de realiseringsvanskeligheder, som skyldes den indskrænkede konsumefterspørgsel. Hans hensigt var at tilegne sig og udvikle både den klassiske skoles arbejdsværditeori og kriseteorien hos den antiklassiske (eller modklassiske) skole for at kritisere den foreskrevne harmoni hos den førstnævnte.

På dette sted synes hans underkonsumtionsteori om krisen i »Grundrids « at mangle det indre forhold til arbejdsværdiloven, kapitalens grundlæggende lov for at opretholde den samfundsmæssige reproduktion under varerelationerne. I modsætning til Sismondi og Malthus opgiver Marx imidlertid ikke arbejdsværditeorien, men forsøger at udvikle den systematisk som kapitalens bevægelseslov i dens historiske former, idet han kritiserer begrænsningerne i den klassiske værditeori. Derfor når han også frem til at kritisere overproduktions/ underkonsumtionsteorien på den ene side for så vidt som den er i modstrid med kapitalens bevægelseslove, baseret på værdiloven.

For eksempel siger Marx i sin kritik af Proudon, at det er overfladisk at udlede nødvendigheden af overproduktion af det faktum at »arbejderen ikke kan tilbagekøbe sit produkt« (Gr. s. 326, p. 306). Og han fortsætter med at overveje de indre relationer mellem forskellige sektorer, som producerer hhv. råmaterialer, maskiner, arbejdernes livsfornødenheder og luksusprodukter. I dette uudviklede fors $\varnothing \mathrm{g}$ på at konstruere et reproduktionsskema viser han, hvorledes vareproduktet fra hver sektor kan købes og konsumeres som enten konstant kapital (hvilket klassikerne har en tendens til at forbigå), variabel kapital eller merværdi. Når det indre forhold mellem produktionen og

4. T. R. Malthus, »Principles of Political Economy«, 2. ed. 1836, p. 7.

5. ibid, pp $398-413$.

6. Simonde de Sismondi, »Nouveaux Principes d'economie politique« 1819, Tome 1, pp. 319 - 20, 33.

7. Ibid, p. 338.

8. Se også E. von Bergmann, »Geschichte der Nationalökonomischen Krisentheorien «. 1895, for detaljer om Malthus og Sismondis kriseteorier. 
konsumtionen af vareproduktet i kapitalens bevægelser således betragtes på grundlag af værdiloven, bliver det klart, at produktionsudvidelsen under kapitalismen ikke kun frembringer en større forbrugsefterspørgsel hos arbejderne, men også en vækst i behovet for produktionsmidler. Dette stiller spørgsmålstegn ved hans tidligere forestilling om, at en almindelig overproduktion forekommer fordi »det endelige produkt finder sin grænse ved det umiddelbare og endelige konsum.« Således ender Marx sin diskussion her, idet han antyder at det centrale ikke er den blotte balance mellem produktion og konsumtion, men snarere dennes begrænsning af kapitalens værdiøgningsproces. Dette sker på følgende måde:

»...almen overproduktion fandt ikke sted, fordi der relativt var produceret for lidt af de varer, som arbejderne skal konsumere, eller for lidt af de varer, som/kapitalisterne skal konsumere, men fordi der var produceret for meget af begge - ikke for meget for konsumet, men derimod for at fastholde det rigtige forhold mellem konsum og vardiфgning; for meget for vardiøgningen."(Gr. s. 346-47, p. 325).

Men hvad betyder så »for meget produktion for værdiøgningen«? Dette problem præsenteres endnu ikke i »Grundrids «. Imidlertid finder vi en anden slags fors $\emptyset$ gsvis tilgang til krisens logiske nødvendighed i del III af »Kapitlet om kapitalen«. Nemlig et fors $\varnothing \mathrm{g}$ på at konstruere en kriseteori i forhold til loven om profitratens faldende tendens.

I profitteorien $\mathrm{i}$ »Grundrids « mangler teorien om produktionspriserne stadig. Den udtrykker simpelthen profitbegrebet og profitratebegrebet som forholdet mellem den totale samfundsmæssige merværdi og kapitalens samlede værdi, og går så direkte videre til teorien om profitratens faldende tendens:

»Når den samme merværdi, dvs. det samme forhold mellem merarbejde og nødvendigt arbejde er forudsat, afhænger profitraten altså af forholdet mellem den del af kapitalen, som udveksles med levende arbejde og den del, som eksisterer i form af råmaterialer og produktionsmidler. Jo mindre den del bliver, som udveksles med levende arbejde, desto mindre bliver profitraten «. Og produktivitetsudviklingen i forbindelse med kapitalakkumulationen »udtrykker sig som en mindre del af kapitalen, der udveksles med levende arbejde, i forhold den del af kapitalen, som eksisterer som konstant værdi«. (Gr. s. 633).

På grundlag af dette begreb om profitratens faldende tendens, fortsætter Marx sin diskussion på følgende måde: - »Idet den frembringer profitratens faldende tendens, ... bliver udviklingen af produktivkræfterne ud over et bestemt punkt til en skranke for kapitalen; kapitalforholdet bliver altså en skranke for udviklingen af arbejdets produktivkraft ... I skærende modsigelser, kriser, kramper udtrykker den tiltagende uforenelighed mellem samfundets produktive udvikling og dets hidtidige produktionsforhold.«(Gr. s. 635, se også s. 636).

Her adskiller Marx's diskussion sig fra Ricardos teori om profitratens faldende tendens. Ricardo troede, at »med samfundets udvikling har arbejdets naturlige pris altid en tendens til at stige $\ll^{9}$, idet han forudsatte, at kornpriserne

9. D. Ricardo, On the Principles of Political Economy and Taxation, Camb. Univ. Press, 1951, p. 93. 
havde en tendens til at stige på grund af jordens mindskende frugtbarhed, og at det så ville være »profitratens naturlige tendens at falde «. ${ }^{10}$ Imod dette forsøger Marx at vise, at det ikke er en naturlig faktor som frugtbarheden, der ligger udenfor kapitalen, men de voksende produktivkræfter indenfor selve kapitalen, som er årsag til profitratens faldende tendens. Sammen med hans opdagelse af principperne for reproduktionen af den konstante kapital, som den klassiske skole havde forbiset, var dette en teoretisk præstation.

Tilbage står dog det fundamentale spørgsmål, om denne profitratens faldende tendens, som skyldes kapitalens stigende sammensætning, virkelig frembringer kriser, når den går ud over »et særligt punkt«. Det er først og fremmest vanskeligt at forklare krisernes cykliske natur umiddelbart ud fra dette, da det ikke er en cyklisk, men derimod en langsigtet bevægelsestendens. Endvidere indebærer denne tendentielt faldende profitrate ikke nødvendigvis en afgørende hindring for kapitalakkumulationen. For denne tendentielt faldendende profitrate, som skyldes kapitalens stigende sammensætning, kan forekomme selvom merværdiens absolutte mængde vokser. Alt afhængig af produktionen af relativ merværdi kan den absolutte mængde merværdi blive ved med at vokse, og kapitalakkumulationen kan også fortsætte, omend i mindre hastig takt. ${ }^{11}$ På dette punkt adskiller Marx's teori om profitratens faldende tendens sig klart fra Ricardos teori, som indeholder en formel nødvendighed af en absolut formindskelse af profitmassen, omend den er baseret på en forkert forudsætning om umuligheden af en

10. Op. cit., p. 120.

11. Efter min mening var Marx fra begyndelsen klar over, at loven om profitratens tendens til fald, på basis af kapitalens stigende sammensætning, hører sammen med produktionen af relativ merværdi. Imidlertid fortsætter Marx sin diskussion, idet han omhyggeligt undersøger det skiftende forhold »mellem den del af kapitalen, som udveksles med levende arbejde, og den del, som eksisterer i form af konstant kapital«. (Se også »Kapitalen«, III, kap. 13). Samtidig må vi bemærke, at han ikke regner produktionen af »relativ merværdi« som en »modvirkende faktor« (kun produktionen af den absolutte merværdi behandles som »stigende udbytningsintensitet«) i kap. 14, i modsætning til »Loven som sådan« $\mathrm{i}$ kap. $13 \mathrm{i}$ »Kapitalens « tredje bind. Dette skyldes, at han allerede tog hensyn til denne faktor i udviklingen af »Loven som sådan «i kap. 13.

Som Marx siger, vil et bestemt antal levende arbejdere efterhånden bruge mere og mere dødt arbejde, oplagret i form af produktionsmidler, dvs. konstant kapital (c), i takt med kapitalens stigende organiske sammensætning. Et bestemt antal levende arbejdere skaber med en given længde og intensitet på arbejdsdagen årligt det samme værdiprodukt, indbefattet såvel merværdien (m) som den genskabte variable kapital (v). Derfor kan vi teoretisk erkende, at forholdet $(\mathrm{m}+\mathrm{v})$ falder absolut i takt med den stigende sammensætning af kapitalen, uafhængig af forandringerne eller stigningen i merværdiraten, dvs. m' $=\mathrm{m}$. Faldet i forholdet $(\mathrm{m}+\mathrm{v})$ vil gå mod uendeligt når kapitalens organiske sammensætning går mod uendeligt i den langsigtede akkumulationsproces. Den almene profitrate $\mathrm{p}^{\prime}=(\mathrm{m})$, som den formuleres af Marx, er helt klart altid mindre end forholdet $(\mathrm{m}+\mathrm{v})$. Derfor må p' have en tendens til at falde selv med en stigende merværdirate, da forholdet $(\mathrm{m}+\mathrm{v})$ falder uendeligt i det lange $1 \varnothing \mathrm{b}$. Jeg er enig med R. L. Meeks diskussion af dette forhold, og hans fortolkning af Marx's udlægning af denne lov i hans »Economics and Ideology and other Essays «, 1967, pp 131-35. Min position er således at Marx’s lov om profitratens faldende tendens kan bevises, men at denne lov ikke kan bruges direkte til at bevise den logiske nødvendighed af $\varnothing$ konomiske kriser af cyklisk natur, som det er blevet diskuteret ovenfor. 
produktivitetsstigning i landbruget. Hvis processen med profitratens tendentielle fald indbefatter lejlighedsvise, pludselige og kraftige formindskelser af profitraten, som forårsager de cykliske kriser, bør vi præcisere, hvorfor disse nødvendigvis må opstå. Vi kan bemærke at Marx's overakkumulationskriseteori endnu langt fra er fuldstændig $\mathrm{i} »$ Grundrids $«$.

\section{Kriseteorien i »Theorien über den Mehrwert«.}

Theorien über den Mehrwert er hovedsagelig en udgivelse af numrene 6, 15,18 og delvis nr. 21 og 22 af de 23 noteshefter som blev skrevet mellem 1861 - 63 som det andet manuskript til »Kapitalen«. På flere måder viser det udviklingen i Marx's teoretiske forskning fra »Grundrids« til »Kapitalen«. Hvad angår kriseteorien, så er diskussionen af denne koncentreret i kapitel XVII i del II, »Ricardos akkumulationsteori. Kritik af denne (Udvikling af kriserne ud af kapitalens grundform). «

Marx's diskussion lægger som i »Grundrids« stadig hovedvægten på overproduktionsteorien. Eksempelvis skriver han »Kapitalens blotte (umiddelbare) produktionsproces kan i sig selv intet nyt tilføje« om krisens årsag. Thi problemet om realiseringen, som forårsager kriser »kan først fremtræde i cirkulationsprocessen, som i sig selv samtidig (er) reproduktionsproces." (Theorien, 2, s. 513) ${ }^{12}$ Den viser udvikling af »krisens mulighed, som blev åbenbar i varens simple metamorfoser, « og som fik sit »indhold « eller »grundlag « gennem kapitalens bevægelser. (Theorien, 2, s. 508-11).

Marx fastholder delvis her en underkonsumtionsindfaldsvinkel til forklaringen på krisens nødvendighed, idet han skriver: »Overproduktionen opstår netop på grund af, at folkets masser aldrig kan konsumere mere end den gennemsnitlige mængde livsfornødenheder, at deres konsumtion altså ikke vokser i takt med arbejdets produktivitet.« (Theorien, 2, s. 469). Han lægger imidlertid mere vægt på en slags disproportionalitetskriseteori, svarende til hans undersøgelser af de intersektorale forhold blandt kapitalerne.

I sin kritik af Ricardo, som benægter muligheden af almindelig overproduktion af varer selv om han anerkender muligheden af delvis overproduktion, siger Marx: »For at en krise (altså også overproduktionen) skal blive almen, er det tilstrækkeligt at den rammer de vigtigste handelsartikler.« (Theorien, 2, s. 506). Og idet han fremhæver, at hvis der fandtes en overproduktion af bomuldsklæde, ville det ikke kun berøre arbejderne i denne

12. K. Marx, »Theorien über den Mehrwert«, del 2, i Marx Engels Werke, bind 26.2, 1967. 
sektor, men også spindere, bomuldsdyrkere, ingeniører, jern- og kulproducenter, fortsætter Marx:

»Hvis det nu ikke kun er indenfor bomuld, men også indenfor lærred, silke og uld, at der har fundet en overproduktion sted, så forstår man, hvorledes en overproduktion af disse få, men væsentlige artikler fremkalder en mere eller mindre almen (relativ) overproduktion på hele markedet«. (Theorien, 2, s. 523-24). »Da kapitalismen imidlertid kun kan give sig selv frie tøjler i visse sfærer under bestemte omstændigheder, så ville en kapitalistisk produktion overhovedet ikke være mulig, hvis den skulle udvikle sig samtidigt og ligeligt i alle sfærer. Fordi overproduktionen er absolut i disse sfærer, er den også relativ i de sfærer, hvor der ikke har fundet nogen overproduktion sted.« (Theorien, 2, s. 532).

Således hævder Marx her, at den disproportionale og delvise overproduktion, som ifølge Ricardo altid må udlignes gennem kapitalens bevægelser, nødvendigvis fører til almen overproduktion og krise gennem påvirkning mellem sektorerne, hvis den indtræffer for de vigtigste varers vedkommende. Marx's overproduktions-kriseteori bliver mere nuanceret ved tilføjelsen af dette disproportionalitetssynspunkt til det hidtidige underkonsumtionssynspunkt.

Selvom Marx stadig lægger vægt på realiseringsvanskelighederne i cirkulationsprocessen udenfor den umiddelbare produktionsproces, betragter han nu også cirkulationsprocessen som en del af kapitalens reproduktionsproces, indbefattet forholdet mellem forskellige produktionsbrancher. Dette tyder på, at han her forsøger at finde den kapitalistiske produktions vanskeligheder, som de udspringer af kapitalens egen reproduktionsproces. Samtidig betragter han ikke længere kriserne ensidigt som værende en modsætning til eller en ophævelse af værdiloven eller af kapitalens bevægelseslove. Han antyder ikke alene, at kriserne opstår ud fra et sammenbrud i kapitalernes udligningsproces, baseret på værdiloven, men også at »krisen selv kan være en form for udligning «. (Theorien, 2, s. 522). Her er kriseteorien ved at blive adskilt fra den såkaldte sammenbrudsteori og udviklet som reproduktionens eller akkumulationsteoriens konkrete form.

Samtidig med at kapitalakkumulationsprocessen uophørligt forårsager anarkiske disproportionaliteter i fordelingen af mængden af arbejde mellem de forskellige produktionsbrancher, kan den imidlertid sædvanligvis udligne denne disproportionalitet gennem konkurrencen med kreditsystemer blandt kapitalerne i takt med markedsprisernes bevægelser. Dette viser værdilovens konkrete regulering af den almindelige kapitalakkumulationsproces. ${ }^{13}$ Selvom kapitalismens

13. Justeringen af investeringerne blandt forskellige sektorer så de passer til markedsprisernes fluktuationer viser ikke kun den konkrete regulering af værdiloven, men sætter den også igennem. Værdiloven betyder grundlæggende reguleringen af vareværdierne ved hjælp af det samfundsmæssigt nødvendige arbejde, som medgår til produktionen af dem. Imidlertid kan denne regulering af værdierne ved hjælp af arbejdstiden ikke opretholdes uden en tilpasning af fordelingen f den arbejdskraft, som er nødvendig til at opretholde den samfundsmæssige reproduktion på tværs af forskellige produktionsgrene. Konkurrencemæssige bevægelser i investeringerne, som følger markedsprisernes og profitratens svingninger, danner, samtidig med at de forårsager en uophørlig uligevægt i fordelingen af arbejdskraft, de konkrete mekanismer, der tilpasser fordelingen af 
anarkiske natur tages for givet, er det derfor stadig vanskeligt at forklare hvorfor alvorlige disproportionaliteter, som indbefatter en overproduktion af de $»$ vigtigste artikler« og som er tilstrækkelige til at forårsage en almen krise, nødvendigvis må indtræffe og endvidere i cyklisk form. Det forekommer usandsynligt at sådanne alvorlige disproportionaliteter skulle indtræffe uden fremkomsten af en eller anden usædvanlig særlig vanskelighed indenfor kapitalakkumulationsprocessen i sin helhed. Hvordan kan så en sådan usædvanlig vanskelighed indtræffe, som ikke kan overvindes på anden måde end gennem en dyb krise?

Overakkumulationsteorien kunne give et svar. Men $\mathrm{i} \gg$ Theorien über den Mehrwert « er denne type teori næsten ikke udviklet. Marx rejser imidlertid følgende problem, som hænger sammen med dette forhold.

Ricardo benægtede muligheden af en almen overproduktion af varer, ikke udelukkende fordi han akcepterede Says teori om udbud og efterspørgsel, men på grund af hans opfattelse af, at en overakkumulation af kapital kun kunne indtræffe $\mathrm{i}$ en alt for fjern fremtid eller $\mathrm{i}$ en alt for tilfældig og specifik situation til at den kunne behandles principielt. Omend dette synspunkt på en måde var logisk konsistent, svarede det helt klart ikke til kapitalismens reale udvikling efter Ricardos tid. Ikke desto mindre fortsatte hans efterfølgere på en inkonsistent måde både at benægte muligheden af en almen overproduktion af varer, og at forklare de cykliske kriser ud fra et overskud af kapital.

»Hvad ville Ric(ardo) så have sagt til hans efterfølgeres stupiditet, som fornægter overproduktionen i en form (som en almen overflod af varer på markedet) og som ikke kun indrømmer den, men gør den til et væsentligt punkt i deres doktriner i en anden form som overproduktion af kapital, plethora af kapital, overflod af kapital?« (Theorien, 2, s. 497). Det må gøres klart at kriserne indeholder begge former for overproduktion. »Der bliver altså kun det spørgsmål tilbage, hvordan de to former for overproduktion forholder begge former for overproduktion. »Der bliver altså kun det spørgsmål tilbage, hvordan de to former for overproduktion forholder sig til hinanden? ... Spørgsmålet er altså: hvad er plethora af kapital, og hvorved adskiller denne sig fra overproduktion?« (Theorien, 2, s. 498).

Marx undersøger stadig ikke dette vigtige spørgsmål, som han stiller i »Theorien über den Mehrwert«. Han går over til at diskutere overproduktionsteorien som vi har set det. Spørgsmålet om hvad overproduktionen eller plethoraen af kapital er, står således stadig ubesvaret tilbage.

Marx's teoretiske undersøgelser før og i »Theorien über den Mehrwert« synes på to måder at mangle grundlaget for et svar på spørgsmålet. På den ene side er en teoretisk behandling af kreditsystemets funktion klart nødvendig for at klargøre forskellen og forholdet mellem overproduktionen af kapital og plethoraen af kapital, hvor den sidste er »et udtryk, som hele tiden kun

arbejdskraft på basis af værdiloven. Denne konkrete regulering af varepriserne ved hjælp af den kapitalistiske værdilov forudsætter endvidere at det samfundsmæssige produktionsforhold mellem kapital og lønarbejde reguleres på grundlag af værdiloven for varen arbejdskraft. Derfor må vi teoretisk anerkende og videreudvikle værdiloven som den grundlæggende lov for hele den kapitalistiske produktionsmådes bevægelser. 
bliver brugt om den rentebærende, dvs. pengekapitalen«. (K. III s. 493, p. 627). Marx bemærkede fra begyndelsen kreditsystemets vigtige rolle i kapitalismens udvikling, og fremhævede allerede $\mathrm{i} \gg$ Grundrids «, at kapitalens tendens til at formindske cirkulationstiden »er kredittens og (andre af) kapitalens kreditindretningers grundbestemmelse«. (Gr. s. 552, p. 509). Også et andet sted i »Grundrids « fremhæver han: »i en almen overproduktionskrise er modsigelsen ikke en modsigelse mellem de forskellige arter af den produktive kapital, men derimod mellem den industrielle og den udlånelige kapital - mellem kapitalen, således som den direkte er involveret i produktionsprocessen, og således som den fremtræder uden for samme (relativt) selvstændigt som penge.« (Gr. s. 316, p. 297). Ligesom hans udvikling af disproportionalitetsteorien, kommer han så $\mathrm{i}$ »Theorien über den Mehrwert « frem til at hellige sig det faktum at en kædereaktion af betalingsudygtighed blandt kapitalisterne, som er indbyrdes forbundet af den kommercielle kredit, formidler krisens udbrud. (Theorien, 2, s. 512). Marx's renteteori, som den er udviklet indtil »Theorien über den Mehrwert « indeholder imidlertid endnu ikke en systematisk undersøgelse af kreditmekanismerne, men udvikler kun den rentebærende kapitals abstrakte form, idet der udover de industrielle kapitalister er forudsat pengekapitalister. Ifølge de oprindelige planer ${ }^{14}$ var det for Marx en tvingende nødvendighed at udvide analysen afgørende ud over »kapitalen i almenhed « for at klargøre kapitalens bevægelser i den industrielle cyklus, formidlet over kreditsystemet.

På den anden side var en korrekt teori om den kapitalistiske befolkningslov under akkumulationsprocessen også en tvingende nødvendighed for at kunne præcisere forestillingen om overproduktion af kapital i forhold til den arbejdende befolkning som vi har set det i »Kapitalen «. Marx forberedte en sådan teori i kapitel XVIII $\mathrm{i} »$ Theorien über den Mehrwert«, idet han understregede at »med kapitalens akkumulation indtræffer der en forandring i dens organiske sammensætning og den konstante del af denne vokser i hurtigere takt end den variable.« (Theorien, 2, s. 564) og at »Maskineriet skaber stedse en relativ overbefolkning, en reservearmé af arbejdere«. (Theorien, 2, s. 556). I modsætning til i »Kapitalen« overser Marx imidlertid næsten de cykliske forandringer i dannelsen og opsugningen af den relative overskudsbefolkning her, idet han udelukkende lægger vægt på det første forhold. Hans studier af den

14. Den oprindelige plan for Marx's arbejde, som blev udarbejdet i slutningen af 1850'erne da han skrev »Grundrids «, bestod af seks hoveddele, dvs. kapitalen, jordejendommen, lønarbejdet, staten, udenrigshandelen og verdensmarkedet. Kapitalens første del var endvidere delt i fire kapitler: (a) kapital i almenhed, (b) konkurrencen, (c) kreditten, (d) aktiekapitalen. Det teoretiske system i »Grundrids« var i denne plan stadig klart afgrænset indenfor rammerne af »Kapital i almenhed «. Imidlertid diskuteres forholdet mellem denne oprindelige plan og »Kapitalens « teoretiske systematik. Jeg vil i et vist omfang behandle dette såkaldte planproblem i et andet essay, som er under forberedelse, hvor jeg også vil forklare vores forståelse af den metodologiske nødvendighed af at dele de Marxske analyseniveauer i princip, faseteori og analyse i relation til planproblemet. 
kapitalistiske befolkningslov var således for uudviklet til på dette punkt at understøtte en overvejelse af teorien om overakkumulationskrisen.

\section{Færdiggørelsen af kriseteorien i »Kapitalen«}

Overakkumulationsteorien i »Kapitalen«, som klargør hvad »overproduktion af kapital« er i relation til den arbejdende befolkning, er af største betydning. Den giver ikke kun et korrekt svar på spørgsmålet om »hvad overfloden eller plethoraen af kapital er fra »Theorien über den Mehrwert«, men udgør i virkeligheden en ny kriseteori, som er helt specifik for $\gg$ Kapitalen $\ll .{ }^{15}$ Selvom det i tredje del af bind III stadig fremstilles som om det er en diskussion »under den ekstreme forudsætning, som her blev opstillet« (K. III, s. 265, p. 336), er det på ingen måde en tilfældig idé, men derimod et logisk resultat af den teoretiske udvikling af Marx's forskning fra »Theorien« til »Kapitalen«. Thi den hænger sammen med og forudsætter på den ene side undersøgelsen af kreditsystemet i femte del af bind III, hvor distinktionen og forholdet mellem overproduktion af kapital og plethora af kapital bliver fremhævet, og på den anden side udviklingen af den kapitalistiske befolkningslov i syvende del af bind I, hvor den cykliske opsugning i dannelse af den relative overskudsbefolkning inddrages i overvejelserne.

Denne type kriseteori, som fokuserer på den »absolutte overproduktion af kapital«, er, som den bliver dannet $\mathrm{i} »$ Kapitalen« for første gang, imidlertid ikke komplet hvad angår overakkumulationens fulde betydning og logiske nødvendighed. Svarende til dens ufuldstændighed fastholdes også overproduktionsteorien i »Kapitalen«. Denne type kriseteori er en udvidelse af Marx’s fors $\emptyset \mathrm{g}$ i »Grundrids « og »Theorien« på, som vi har set, at udvikle kriseteorien af Sismondis og Malthus's anti-klassiske skole, idet han udefra kritiserer den klassiske skoles begrænsninger. Den kan betragtes som en anti-klassisk rest i kriseteorien i »Kapitalen«. Den synes at forveksle mellemliggende faktorer eller resultater af krisen med årsagerne. Den har fundamentale vanskeligheder med at bevise den

15. I »Den marxistiske teori om kriser, kapital og staten« (Bulletin of the CSE, vinteren 1972, udkommet 1974 på Modtryk) bruger David Yaffe ikke denne teori korrekt. Han sætter ikke den »absolutte overakkumulation af kapital« i forhold til den arbejdende befolknings beskæftigelsesniveau hvilket her er centralt for Marx's synsvinkel. Selvom jeg er enig med hans kritik af overproduktionskriseteorien, er jeg bange for at hans positive forklaring vil tilsløre Marx's teoretiske fremskridt med overakkumulationsteorien fra »Grundrids « til »Kapitalen«. Yaffes og M. Cogoys fors $\varnothing \mathrm{g}$ (i »Profitratens fald og akkumulationsteorien« i Bulletin of the CSE, vinteren 1973, udkommet i Politiske Arbejdstekster nr. 3-4 april 1974) på at udlede de cykliske krisers begreb direkte fra loven om profitratens faldende tendens synes stadig kun at vise kapitalakkumulationens abstrakte behov for og ikke den logiske nødvendighed af cykliske kriser. 
generelle overproduktions cykliske natur og logiske nødvendighed, særlig i forhold til værdilovens funktion, på basis af hvilken kapitalen kan udligne den vedvarende uligevægt mellem udbud og efterspørgsel af forskellige varer, så længe den konkurrencemæssige kapitalakkumulation fortsætter som helhed.

Den egentlige svaghed ved overproduktionsteorien hidrører fra dens grundlæggende indfaldsvinkel, hvor den søger kapitalens vanskeligheder ikke indenfor produktionsprocessen, men derimod i cirkulationsprocessen, som er uden for (eller står i et formidlet forhold til) produktionsprocessen. I modsætning hertil viser overakkumulationsteorien hvordan »Den egentlige skranke for den kapitalistiske produktion er kapitalen selv, «(K. III, s. 260 p. 329) idet den bevæger sig gennem såvel produktions- som cirkulationsprocesser. Marx's fors $\emptyset \mathrm{g}$ på at klargøre den logiske nødvendighed af cykliske kriser skal således videreføres ved en udvikling af den sidste og ikke den første type kriseteori.

Overakkumulationsteorien i »Kapitalen« er imidlertid ufuldendt på adskillige punkter.

Som vi har omtalt behandler »Kapitalen« i modsætning til »Theorien« forandringer i opsugningen af og forskydninger i den relative overskudsbefolkning i teorien om den kapitalistiske befolkningslov. Marx beskæftiger sig nu ikke længere udelukkende med dannelsen af den relative overbefolkning. For eksempel behandler han »den voksende efterspørgsel efter arbejdskraft ved akkumulation, når kapitalens sammensætning er uforandret«, i første del af kapitel 23 »den generelle lov for den kapitalistiske akkumulation«. Han klargør imidlertid ikke helt den teoretiske nødvendighed og betydning af denne del. Og han fortsætter med at understrege den progressiv(e) produktion af en relativ overbefolkning eller industriel reservearmé «, som ledsager den »relativ(e) aftagen af den variable kapitaldel, samtidig med at akkumulationen og den koncentration, der ledsager den, går videre «, som 'den generelle lov for den kapitalistiske akkumulation' efter del 2 af det samme kapitel, temmelig uafhængigt af diskussionen i første del. Følgelig beskrives den kapitalistiske befolkningslov stadig med for stor vægt på den fremadskridende dannelse af en overskudsbefolkning.

Det er muligt, at Marx var stærkt påvirket af eksistensen af forskellige former for massive reservearméer i det engelske samfund på hans tid, når han nævner dem for at illustrere sin teori om den relative overbefolkning. Denne analyse af reservearméns konkrete former er således meget vigtig i forbindelse med den konkrete analyse af den engelske kapitalisme på dette tidspunkt, men det bør også bemærkes at disse konkrete former for reservearmé ikke kun indbefatter den relative overbefolkning, som produceres af selve den kapitalistiske produktion, men også den overskudsbefolkning, som stammer fra opløsningen af de små vareproducenter og småbønderne. Hvis vi, som professor Uno foreslår, opererer med systematiske forskningsniveauer som principielle bestemmelser, faseteori og analyse, skal vi ikke inddrage den sidste del af overskudsbefolkningen, når vi belyser de grundlæggende principper. For at blotlægge de grundlæggende 
principper i den kapitalistiske økonomi, må vi koncentrere os helt om den kapitalistiske produktions bevægelseslove, uden direkte at henvise til deres konkrete relationer til ikke-kapitalistiske producenter.

Desuden forekommer det teoretisk ukorrekt ikke at overveje den faste kapitals specifikke skranker i forbindelse med behandlingen af produktionsmetodens udviklingsproces under den kapitalistiske akkumulation og dens indvirkning på arbejderklassen. I denne sammenhæng skulle teorien om kapitalakkumulationen ikke have været placeret i slutningen af bind $\mathrm{I}$, men efter »Kapitalens omslag « $\mathrm{i}$ bind II, og have dannet en teoretisk del af kapitalens reproduktion sammen med teorien om reproduktionsskemaerne. Under normale omstændigheder har kapitalisterne allerede fast kapital i deres produktionsproces, som de anvender som en del af den profitskabende kapital. Og de forvandler merværdi til kapital, succesivt og privat og derfor $i$ et lille og spredt omfang på basis af det allerede eksisterende produktionsudstyr. ${ }^{17}$ Kapitalakkumulationen foregår normalt under disse betingelser som en udvidelse af kapital i stedet for en intensivering af kapital på basis af allerede eksisterende produktionsmetoder. Forsøg på at opnå ekstramerværdi ved at indoptage mere fremskredne produktionsmetoder er snævert afgrænsede og foregår kun delvis i en sådan proces. I en prosperitetsperiode er det således usandsynligt at kapitalen vil stræbe efter at producere relativ merværdi og at skabe en relativ overbefolkning ved at kassere og erstatte den eksisterende faste kapital med en anden. ${ }^{18}$

16. Professor Kouzo Uno har fors $ø$ gt at rense Marx’s kriseteori i denne retning i hans »Principle of Political Economy« (2 bind 1950, 52) og i »Crisis Theory« (1953). Dette fors $\emptyset$ g er blevet understøttet af hans efterfølgeres arbejde, her i blandt min »Credit and Crisis« (1973), hvoraf en del er refereret her. (Disse titler foreligger dog så vidt vides kun på japansk. O.A.).

17. Selvom aktiekapitalformen gjorde det muligt at samle profitter og ledige fonds til nye storstilede investeringer, havde de vigtigste dele af den industrielle kapital ikke antaget denne form før efter slutningen af det 19. århundrede, hvor de cykliske krisers typiske faser allerede havde forandret sig og efterlod en dødvægt af vedvarende overskudskapital i industrierne. De monopolistiske aktieselskaber blev dannet for at delvist at undgå dette vedvarende problem med overskudskapital. Aktiekapitalens funktion og dens kapitalistiske begrænsninger kan imidlertid ikke indgå i overvejelserne her, hvor de cykliske krisers væsen behandles på den empiriske basis af kapitalismen på Marx's tid.

18. Særlig i prosperitetsprocessen, hvor kapitalerne kan fortsætte med at vokse værdimæssigt, idet de anvender det eksisterende produktionsudstyr, kan grundlæggende forbedringer af produktionsmetoderne kun vanskeligt realiseres på grund af visse skranker, der i detaljer er som følgende: (I) hvis dette udstyr endnu ikke er ufuldstændig værdiforringet, bliver omkostningerne ved at opgive den tilbageblevne kapitalværdi en byrde, når det skal fornyes, (II) selv efter værdiforringelsen »er maskineriet yderst værdifuldt for kapitalen når dets værdi $=\mathrm{O} \ll$ (Grundrids, s. 652) og således ikke fuldt udrangeret så længe som det fungerer fysisk, (III) profitterne har en tendens til at blive lagt til kapitalen så hurtigt så muligt frem for at blive oplagret længe nok til at opbygge nye udstyrssystemer eller nye fabrikker. Under nedgangsfasen, hvor det eksisterende udstyr ikke fuldt ud kan fungere som kapital og opnå merværdi, bliver udstyret i modsætning til før udskiftet, og kapitalerne tvinges til at søge at udskifte produktionsmetoderne fuldstændigt ved at kassere og genopbygge de faste kapitaler, for at overvinde kapitalakkumulationens vanskeligheder. 
Marx siger også, når han fremstiller »den absolutte overproduktion af kapital«, at en udvidelse af den relative merarbejdstid $» . .$. ville... være ugørligt i en situation som denne, hvor efterspørgslen efter arbejdskraft er så stærk, og der altså er tendens til lønstigning « (K. III, s. 262, p. 331). Hvis vi igen rent principielt betragter kapitalens akkumulationsproces i forhold til den eksisterende faste kapital, vil den voksende efterspørgsel efter arbejdskraft, som følger med akkumulation under uændret kapitalsammensætning ikke fremtræde som en tilfældig, men som en nødvendig proces, som er fremherskende i prosperitetsperioder. »Et dybt og pludseligt fald i den almindelige profitrate « forårsaget af lønstigninger ville ikke længere være en ren logisk slutning »under de her forudsatte ekstreme forudsætninger «, men blive et nødvendigt logiskt resultat af kapitalakkumulationen i prosperitetsperioden..$^{19}$ Den kapitalistiske produktions fundamentale svaghed - at den er tvunget til at behandle arbejdskraften som en vare uden at være i stand til at producere den som en vare - bliver her afgørende for kapitalakkumulationen.

Men hvorfor kan overakkumuleret kapital ikke delvis forblive »ubrugt « uden at forårsage dybe kriser? Eller hvorfor kan kapitalen ikke nedsætte akkumulationshastigheden, når profitraten falder, og på den måde forvandle prosperitet til stagnation uden en drastisk krise? Disse problemer mangler en løsning selv efter at vi har vist den logiske nødvendighed af, at der indtræffer overakkumulation af kapital. For at løse disse problemer er det væsentligt at forstå, hvordan konkurrencen på varemarkedet og kreditsystemet fungerer blandt kapitalerne. Her er Marx' bidrag til dette problem, del V af bind III i »Kapitalen«, absolut væsentlig, selvom det, undtagen i den japanske Uno-skole, sjældent er blevet behandlet som en uundværlig del af den Marxske kriseteori.

Vi vil ikke benægte, at den teoretiske systematisering af kreditmekanismerne, som Marx for første gang forsøgte at foretage i bind III af »Kapitalen«, langt fra er fuldstændig. Kreditteorien, indbefattet teorien om den industrielle cyklus, er helt klart den mest ufærdige del i alle »Kapitalens« bind. Særlig er kreditsystemet endnu ikke helt abstrakt bestemt som en indre mekanisme i kapitalistisk produktion. Marx erkender, at kreditsystemet er dannet for at udnytte ubeskæftiget kapital eller for at forkorte den uproduktive cirkulationsperiode i kapitalens omslag, som vi har set i »Grundrids«, og som vi også kan se i bind II af »Kapitalen«. Når han betragter bankkredittens fungeren,

19. I den virkelige proces med cykliske kriser i midten af det 19. århundrede plejede prisstigninger på landbrugsprodukter, som f.eks. bomuld, uld etc. sammen med stigende lønninger i slutningen af prosperiteten at skabe vanskeligheder for den engelske industrikapitals akkumulation. Den engelske industrikapital plejede i virkeligheden at overakkumulere, ikke kun i forhold til den arbejdende befolkning, men også til det uelastiske udbud af landbrugsmæssige råmaterialer, som ikke blev produceret indenfor dens egen produktionsproces. På de principielle bestemmelsers område, hvor alle produktionsfaktorerne undtagen arbejdskraften forudsættes at være produceret af kapital, må en sådan konkret skranke for den engelske industrikapital bortabstraheres og betragtes som en overakkumulation af kapital udelukkende i forhold til den arbejdende befolkning. 
lægger han imidlertid i virkeligheden vægt på »pengekapitalister« og andre indskydere udover industri- eller handelskapitalisterne. Selvom der under den reale kapitalisme virkelig findes forskellige former for indskydere som f.eks. rene pengekapitalister, burde kreditsystemets princip have abstraheret fra disse udvendige faktorer, for at kunne klargøre kreditsystemets væsentlige funktion, som er at lette igangsættelsen af ubeskæftigede elementer af kapitaler, som nødvendigvis opstår i kapitalernes omslag. Thi pengemarkedets regelmæssige bevægelser gennem de industrielle cykler er faktisk væsentligst bestemt af bevægelserne i den gensidige udnyttelse af disse ubeskæftigede kapitaldele.

Vi må her bemærke, at Marx' tilbøjelighed til at lægge vægt på »pengekapitalisterne « i kreditteorien ikke kun stammer det utilstrækkelige teoretiske abstraktionsniveau, men også fra den formelle teori om den rentebærende kapital, som udgår fra renteteorien indenfor rammerne af »kapital i almenhed « $\mathrm{i} \gg$ Grundrids $\ll{ }^{20}$ Kreditsystemets principper burde betragtes som en helt indre mekanisme i den kapitalistiske produktionsmåde og ikke være baseret på udenforstående pengeudlånere eller »pengekapitalister «, som i modsætning til industrielle kapitalister eller handelskapitalister ikke har en væsentlig funktion i den kapitalistiske produktions bevægelser. Derfor bør den kommercielle kredit som »de i reproduktionen beskæftigede kapitalister giver hinanden « i form af veksler behandles som »kreditsystemets basis«. (K. III, s. 496, p. 630). På denne basis ydes bankkreditten således i form af diskontering af veksler fra industri- og handelskapitalister, alt afhængig af den fond, som udgøres af disse kapitalisters indskud og tilbagebetalingen af de forfaldne veksler. ${ }^{21}$ Bankernes evne til elastisk at udvide kreditten ved at udstede pengesedler

20. Renteteorien, med udgangspunkt $\mathrm{i}$ »pengekapitalisterne«, synes at stamme fra den klassiske skoles renteteori, f.eks. A. Smith eller D. Ricardo, som hovedsagelig betragtede renten som et $\varnothing$ konomisk grundlag for den »pengebesiddende klasse «, og som næsten manglede en teori om kreditsystemet.

21. Her må vi tage den væsentlige struktur i det engelske pengemarked i midten af det 19. århundrede som grundlag for den teoretiske abstraktion, ligesom vi burde tage de typiske cykliske kriser i denne periode som grundlag for abstraktionen af kriseteoriens principper. Kapitalmarkedet, indbefattet aktiekapitalens funktion, kan stadig ikke medreflekteres her (se også note 17). Kreditsystemets funktion er således begrænset til den kortsigtede mobilisering af cirkulerende kapitaler, og har ikke noget direkte at gøre med de langsigtede investeringer af fast kapital.

Selvom jeg mener at et sådant kreditbegreb er væsentligt for at afklare Marx’s kriseteori, mener jeg slet ikke, at en sådan konkret situation i kreditsystemet er årsagen til de kapitalistiske kriser. Overakkumulationsteorien viser klart, at krisens nødvendighed stammer fra kapitalens fundamentale vanskelighed med at behandle den menneskelige arbejdskraft som en vare. Skrankerne for udviklingen af produktiviteten, som skyldes den eksisterende faste kapital udgør også en vigtig mellemliggende faktor. Vi må imidlertid lægge mærke til, at overakkumulationen af kapital i stadig mindre grad indtræffer på en regelmæssig periodisk måde, men bliver en vedvarende vanskelighed for kapitalismen i den imperialistiske fase, hvor det financielle system også er forandret, så det svarer til de grundlæggende forandringer i kapitalakkumulationen. Derfor er det vigtigt at danne et begreb for kreditsystemet, baseret på et empirisk grundlag fra Marx's tid, ikke kun fordi dette tjener til at rense Marx's egen kredit- og kriseteori, men også fordi kreditsystemets funktion i forhold til de regelmæssige og cykliske kriser ikke kan klargøres principielt på noget andet empirisk grundlag. 
eller bankveksler reguleres i sidste instans af fondene fra de kapitalister, som er beskæftigede i reproduktionen.

Som Marx påpeger: »Når man betragter den omslagscyklus, hvori den moderne industri bevæger sig ... så vil man finde, at lav rente oftest svarer til tider med højkonjunktur eller ekstraprofit, stigende rente til tiden mellem højkonjunktur og omslaget derfra, men maksimum af rente, lige til ågerrente, svarer til krisen«. (K. III, s. 372, p. 469).

I prosperitetsperioden sikrer »tilbagestrømningernes lethed og regelmæssighed i forbindelse med en udvidet kommerciel kredit ... udbuddet af lånekapital, trods den stigende efterspørgsel og forhindrer renteniveauet i at stige.« Dette er den eneste periode i den industrielle cyklus hvor »relativ rigeligt med kapital, der kan lånes, falder sammen med virkelig udvidelse af industrikapitalen«. (K. III, s. 505, p. 642). Denne situation forandres i slutningen af en prosperitetsperiode, når overakkumulationen af kapital ifølge overakkumulationsteorien indtræffer.

I sammenhæng med overakkumulationsteorien fremhæver Marx nu de bemærkelsesværdige, indre sammenhængende forandringer i løn, profit og rente på følgende måde:

»Det kan øge efterspørgslen efter arbejdskraft, at udbytningen af arbejdet foregår under særlig gunstige omstændigheder, men den stigende efterspørgsel efter arbejdskraft, og således efter variabel kapital, forøger i og for sig ikke profitten, men indskrænker den pro tanto. Men efterspørgslen efter variabel kapital kan dog hermed tiltage, altså også efterspørgslen efter pengekapital, og dette kan forhøje rentefoden. Markedsprisen for arbejdskraft stiger så over sit gennemsnit, der bliver beskæftiget flere end det gennemsnitlige antal arbejdere, og samtidig stiger rentefoden, fordi efterspørgselen efter pengekapital under disse omstændigheder stiger... Hvis arbejdslønnen af en eller anden grund steg under ellers ugunstige konjunkturer, så ville stigningen i arbejdsløn sænke profitraten, men hæve rentefoden i samme grad som den $\varnothing$ gede efterspørgslen efter pengekapital«. (K. III, s. 529, p. 673-74).

Den stigende efterspørgsel efter pengekapital overfor en profitrate, der falder som følge af en stigning i lønnen, bliver et uundgåeligt resultat af kapitalakkumulationsprocessen, når overakkumulationsteorien er udvidet korrekt, som vi har set. Hvis de industrielle kapitalister og handelskapitalisterne imidlertid fortsætter med at sælge deres varer som før, og betale deres forfaldne veksler, danner de således disponible fonds, som igen anvendes af bankerne, og der forbliver hermed et spillerum for bankerne til at udvide deres kredit for at imødekomme den stigende efterspørgsel efter pengekapital. Desuden er det også muligt at kapitalisterne reducerer deres investeringer på grund af den formindskede nettoprofit uden at der opstår et alvorligt sammenbrud i kreditkæden. For at kunne bevise den teoretiske nødvendighed af de dybe kriser, synes yderligere konkretisering således at være nødvendig. ${ }^{22}$

Marx understreger adskillige steder, hvordan spekulationer i forbindelse

22. Selvom jeg fuldstændig stoler på Professor Kouzo Unos kriseteori, er jeg på dette punkt ikke enig i hans tilbøjelighed til at udelade handelskapitalens og spekulationens rolle i forbindelse med krisens væsen. 
med anvendelsen af kreditten får renten til at stige. »En høj rentesats... kan betales - og dette er f.eks. tilfældet i spekulationstider - ikke med profitten, men med selve den lånte fremmede kapital, og dette kan fortsætte et stykke tid.« (K. III, s. 529, p. 673). »Men tilførslen af en artikel kan også falde til under gennemsnittet som f.eks. i forbindelse med misvækst i korn, bomuld etc., og efterspørgslen efter lånekapital vokse, fordi der blive spekuleret $\mathrm{i}$, at prisen vil stige endnu højere, og det nærmeste middel til at få den til at stige består i midlertidigt at unddrage markedet en del af tilførslen. Men for at betale de købte varer uden at sælge dem, bliver der skaffet penge gennem det kommercielle 'vekselvæsen' - I dette tilfælde vokser efterspørgslen efter lånekapital, og rentefoden kan stige som følge af dette forsøg på kunstigt at forhindre varetilførslen til markedet. Den højere rentefod er så udtryk for en kunstig formindskelse af tilførslen af varekapital.« (K. III, s. 530, p. 675).

Marx gør det ikke klart, hvorfor sådanne spekulationer bliver så aktive og vidt udbredte særlig i slutningen af prosperitetsperioder. Han fors øger heller ikke at klargøre forholdet mellem overproduktion af kapital og fremkomsten af massiv spekulation. Det er imidlertid ikke særlig vanskeligt at finde ud af det logisk nødvendige forhold. Når lønnen stiger på grund af overakkumulationen af kapital, presser det ikke kun den almene profitrate, men påvirker nødvendigvis også markedspriserne på varerne på to måder. For det første må priserne på de varer, som er produceret af sektorer, der har en lav organisk sammensætning af kapitalen (dvs. arbejdsintensive sektorer) stige kontinuerligt så længe som lønudgifterne vokser under udligningen af profitraten, som Marx påpeger i kapitel XI af bind III i »Kapitalen«. For det andet kan stigningen i efterpørgslen efter konsumtionsmidler i takt med de stigende lønninger forårsage prisstigninger på konsumvarer eller varer, som anvendes til produktionen af dem, hvis forsyningen af disse varer ikke kan tilpasses umiddelbart, hvilket ofte er tilfældet med landbrugsprodukter.

I modsætning til midten af properitetsperioden, hvor markedspriserne udelukkende svinger indenfor snævre grænser omkring de stabile produktionspriser på baggrund af et stabilt lønniveau, og hvor kapitalens udvidede akkumulation fortsætter på basis af en relativ overskudsbefolkning, stiger markedspriserne på nogle varer således nødvendigvis i slutningen af prosperiteten på grund af overakkumulationen af kapital. Derfor fortsætter med logisk nødvendighed en usædvanlig oplagring af disse varer hos industrielle kapitaler og særligt hos nogle handelskapitaler, som fuldt ud udnytter kreditsystemets elasticitet.

Kreditsystemets elasticitet indsnævres imidlertid, når det benyttes til sådanne massive spekulationer. Flere og flere handelsveksler udstedes og bringes til bankerne for at blive diskonteret. Vekslernes løbetid forlænges og tilbagebetalinger bliver forsinkede eller finder kun sted ved hjælp af ny låntagning. Sammen med den stigende efterspørgsel efter pengekapital til at imødekomme yderligere lønudbetalinger, strammer en sådan spekulativ efterspørgsel efter 
pengekapital altid pengemarkedet gennem en relativ formindskelse af reserverfondene i banker, hvilket resulterer i en stigende rente. Drænet af guldreserver i pengemarkedets centralbank demonstrerer på det kritiske punkt i prosperitetens sidste faser slående denne tendens i kreditsystemet.

Overproduktionen af kapital forårsager således nødvendigvis tredobbelte indbyrdes afhængige vanskeligheder for kapitalen: Stigningen i lønningerne, profitratens fald og stigning i renten. Vanskelighederne med overproduktionen af kapital i forhold til den arbejdende befolkning får et afgørende udtryk i manglen på pengekapital til udlån. Handels- og industrikapitalisternes nettoprofit bliver drastisk beskåret af stigningen i såvel arbejdsløn som rente. Kreditstramningen er i særlig høj grad skæbnesvanger for de spekulative oplagringer, når der yderligere kommer en generel nedgang i de egentlige nettoprofitinvesteringer. Det bliver hurtigt ikke kun vanskeligt, men ligefrem tabsbringende at opretholde spekulationslagrene og betale de stigende renteomkostninger under disse forhold.

Det bliver nødvendigt at sælge med tab for at betale forfaldne veksler. Spekulationernes sammenbrud markerer det $\varnothing$ jeblik, hvor prosperiteten vender og bliver til en dyb krise. Konflikten mellem de modsatte bevægelser i den almindelige profitrate og i renten forårsager således kreditsystemets sammenbrud, og vanskelighederne skærpes af den ulige udvikling og sammenbrud i de massive spekulationer, hvilket også er et nødvendigt resultat af overakkumulationen.

En cyklisk krises begyndelse indvarsles sædvanligvis med at spekulationerne hos handelskapitaler, som er beskæftigede med den store engroshandel bryder sammen. Dette sker, fordi den spekulative oplagring, der benytter sig af kreditten, i slutningen af prosperiteten er udviklet mest intensivt og i størst omfang her, og som derfor rammes af kreditstramningen og den stigende rente som af et alvorligt chock. Og sammenbruddet i disse handelskapitalers spekulationer giver altid både varemarkedet og pengemarkedet et alvorligt chock.

Marx fremhæver også denne begyndelse til krisen, idet han siger at »det ikke er i detailhandelen, som har med det umiddelbare forbrug at gøre, at kriserne først viser sig og bryder ud, men i engroshandelens og bankernes sfærer, som stiller samfundets pengekapital til rådighed for den«. (K. III, s. 316, p. 398). På samme tidspunkt vil såvel handelskapitalernes som industrikapitalernes mere eller mindre spekulativt ophedede handel blive uholdbar og begynde at bryde sammen på baggrund af overakkumulationen. Sammenbruddet i den spekulative lagerophobning vil forårsage et dybt fald i markedspriserne på de varer, hvor priserne er blevet opretholdt eller endda sat i vejret gennem spekulationer. Grundlaget for kreditforholdene, som er blevet opretholdt og udvidet under forudsætning af markedspriser på et bestemt niveau, bliver nu ødelagt. Der indtræf- 
fer en kædereaktion af insolvens. Alle kapitaler og banker begrænser ny kreditgivning på det strengeste for at sikre deres egne betalingsreserver på trods af en stor stigning i efterspørgslen efter pengekapital til betaling af gammel gæld.

Renten når således sin maximale højde igen, så snart den nye krise sætter ind, »Kreditten hører pludselig op, betalingerne stopper, reproduktionsprocessen lammes og der... opstår en omtrent absolut mangel på lånekapital og overflod af ubeskæftiget industrikapital«. (K. III, s. 505, p. 642). Varemarkedets sammenbrud og et generelt besvær med at sælge indtræffer i forbindelse med kredittens indskrænkning og sammenbrud. Dette sammenbrud forstyrrer og indskrænker produktionen i hele brancher, for »reproduktionsprocessens hele sammenhæng beror på kredit « i den kapitalistiske produktionsmåde. (K. III, s. 506, p. 644). På samme måde som Marx beskriver resultatet af den »absolutte overproduktion af kapital «, vil »standsningen og forstyrrelsen afbryde kæden af betalingsforpligtelser til bestemte terminer på hundrede steder. Forvirringen øges yderligere ved, at kreditsystemet, som udvikler sig samtidig med kapitalen, dermed bryder sammen. Alt dette fører således til heftige, akutte kriser, pludselige voldsomme værdiforringelser og virkelig stagnation og forstyrrelse af reproduktionsprocessen og dermed til en virkelig nedgang i reproduktionen.« (K. III, s. 265, p. 334-335).

Ansættelse af arbejdere må også reduceres stærkt med en sådan nedgang i reproduktionen, som skyldes kreditsystemets sammenbrud. Et stort antal arbejdere tvinges til at gå arbejdsløse. En kraftig lønnedgang indtræffer som en reaktion på lønstigningerne i slutningen af prosperiteten. Arbejdernes konsumefterspørgsel formindskes ekstremt. Dette fuldender kæden af vanskeligheder med at sælge kapitalernes varer. Den samtidige forekomst af overflod af ubeskæftiget industriel kapital og en arbejdsløs »overskuds «arbejderbefolkning bliver uundgåelig på grund af mellemkomsten af en absolut mangel på lånekapital. Kapitalværdierne i form af kreditdokumenter, varer og produktionens fysiske elementer destrueres. Dette viser i princippet klart, at den kapitalistiske produktionsmådes bevægelser, som sigter mod en forøgelse af kapitalen, indeholder en modsigelse mellem dens produktionsforhold og dens voksende produktivkræfter.

Det må imidlertid også bemærkes, at den kapitalistiske produktionsmåde ikke forsvinder blot på grund af en økonomisk krise. Principielt går krisefasen nødvendigvis over i en depression. Den anarkiske og ulige destruktion af kapitalerne giver nogle kapitaler mulighed for at bevare en del af deres værdi. Den kapitalistiske reproduktion genoptages af sådanne kapitaler. Men det er ikke let for kapitalen at komme ud af depressionen, for den anarkiske og ulige destruktion af kapitaler under krisen har forårsaget et forvredet forhold mellem produktionsbrancherne. En umiddelbar tilpasning af dette forhold er vanskelig på grund af den eksisterende faste kapitals immobilitet. Kreditsystemet er i princippet dannet for at lette de cirkulerende kapitalers indbyrdes bevægelser og er uanvendelig til at mobilisere værdien af den faste kapital, som eksisterer 
i produktionsprocesserne. På trods af at lånekapitalen nu bliver rigelig og derved afspejler »indskrænkning og lammelse af den industrielle kapital « (K. III, s. 502, p. 638), kan den alligevel ikke spille en positiv rolle ved fjernelsen af depressionens fundamentale vanskeligheder. Overfloden af ubeskæftiget industriel kapital, ubrugt lånekapital og ubeskæftiget arbejderbefolkning, eller lave profitrater, renter og lønninger, eksisterer sammen, ude af stand til at lade sig sammenføje i denne periode.

Igennem denne depressionsperiode vil »prisfaldet og konkurrencekampen ... på den anden side (imidlertid) anspore hver enkelt kapitalist til at bringe den individuelle værdi af hans totalprodukt ned under dets generelle værdi ved anvendelse af nye maskiner, nye og bedre arbejdsmetoder, nye kombinationer « (K. III, s. 265, p. 335). Endvidere er de eksisterende faste kapitaler i modsætning til i prosperitetsperioden, generelt ikke længere profitable, og de tvinges således til at falde i værdi for at blive fornyede så hurtigt som muligt. Når de fleste kapitaler i de vigtigste brancher værdiformindsker en stor del af værdien af deres faste kapital og samler deres egen pengekapital i tilstrækkelig høj grad til at investere i nyt udstyr, optager de de nye produktionsmetoder gennem en fornyelse af den faste kapital. Disse fornyelser af den faste kapital sker via konkurrencen og derfor på samme tid i slutningen af depressionen.

Kapitaler, som det lykkes at optage nye produktionsmetoder, bliver i stand til aktivt at genoptage akkumulationen selv under de reducerede markedspriser. Samtidig er proportionaliteten blandt brancherne grundlæggende genoprettet igennem fornyelsesprocessen af den faste kapital, fordi kapitalerne under denne proces frit kan bevæge sig og investere hele deres værdi i de mest håbefulde brancher. Et forvredet forhold mellem produktionens brancher blive således restitueret svarende til de nye produktionsforhold.

Ikke kun disse forhold mellem kapitalerne, men også det produktive forhold mellem kapital og lønarbejde bliver fornyet. På den ene side formindskes arbejdskraftens værdi på grund af de forbedrede produktionsmetoder, og merværdiraten stiger for at udvide kapitalens akkumulationsbasis. På den anden side stiger kapitalens organiske sammensætning for at skabe den relative overskudsbefolkning, som udgør den grundlæggende betingelse for kapitalen kan nå et værdimæssigt højere akkumulationsniveau end i den forudgående prosperitetsperiode. At en stigende sammensætning af kapitalen, som skaber en relativ overskudsbefolkning er nødvendig og sættes igennem via depressionen, hvor arbejderbefolkningen allerede siden krisen har været overflødig i forhold til kapitalen, viser klart den kapitalistiske udvikling af produktionsmetodernes historiske og fremmedgjorte karakter.

Så snart forholdet mellem kapitalerne og forholdet mellem kapital og lønarbejde er blevet fuldt ud reorganiseret, så det svarer til de nye værdirelationer på basis af det nye produktivkraftsniveau, genoptager kapitalerne en blomstrende udvidelse af produktionen med en genoprettet profitrate. Varehandelen 
kan nu udvides glidende, og kreditsystemet, som underletter denne handel, begynder nu igen at udvides elastisk, som det er karakteristisk for prosperitetsperioden.

Således starter den industrielle cyklus, som består af tre faser: prosperitet, krise og depression, forfra. Hver fase udgør årsagen til den efterfølgende fase, »og den samme onde cirkel (vil) atter blive gennemløbet, med udvidede produktionsbetingelser, med et udvidet marked og med større produktivitet.« (K. III, s. 265, p. 336) »Det forholder sig sådan med denne industrielle cyklus, at når den første impuls er givet, må det samme kredsløb periodisk reproducere sig selv«. (K. III, s. 506, p. 643). Den faste kapitals »livs-cyklus«i de væsentligste industrigrene, »udgør en materiel basis for de periodiske kriser « (K. III, s. 185); den er især af afgørende betydning for den industrielle cyklus varighed, fordi den samtidige fornyelse af den faste kapital i de vigtigste brancher udgør udgangspunktet for enhver ny prosperitetsfase, som vi har set.

Den kapitalistiske produktionsmådes indre modsigelser, som stammer fra den alvorlige vanskelighed med at behandle den menneskelige arbejdskraft som en vare, og som bryder ud i periodiske kriser gennem konkurrencen og kreditten blandt kapitaler, får en faktisk løsning i den industrielle cyklus' forløb. Ikke desto mindre kan de overhovedet ikke løses grundlæggende i dette forløb, og må således fremtræde gentagne gange i disse cykler. De cykliske kriser afslører ikke kun modsigelserne i kapitalens bevægelser, men udgør også en nødvendig del af de konkrete mekanismer i den kapitalistiske udvikling. Tilførslen af varen arbejdskraft, som er den grundlæggende forudsætning for kapitalens akkumulation, sikres principielt gennem den kapitalistiske befolkningslovs konkrete udvikling i form af den industrielle cyklus.

De industrielle cykler indbefattet periodiske kriser, udgør samtidig den konkrete mekanisme, der tilpasser værdiforholdet mellem kapital og lønarbejde og blandt forskellige vareprodukter, til udviklingen af produktivkræfterne. Reguleringen af vareværdierne, så de svarer til den mængde arbejde, som samfundsmæssigt er nødvendig til at reproducere dem, sammen med en nyfordeling af det samfundsmæssige arbejde, som er nødvendigt til at opretholde reproduktionen af varerne, sættes faktisk igennem i løbet af den industrielle cyklus. Den industrielle cyklus udgør således den indre mekanisme, som sætter værdiloven igennem som kapitalens bevægelseslov.

Derfor må den systematiske udvikling af værditeorien i »Kapitalen« indbefatte en kriseteori, og denne kriseteori bør på sin side konkret sammenfatte værdilovens konkrete mekanismer som kapitalens bevægelseslove. Derfor opsummerer kriseteorien i »Kapitalen« i virkeligheden også den fundamentale kritik af den klassiske skole, hvor nødvendigheden af en almen overproduktion eller krise blev betragtet som inkonsistent i forhold til denne skoles værdilov. 
Trods ufuldstændighed er de væsentligste faktorer, som er nødvendige for at fuldende overakkumulationskriseteorien allerede til stede i $\gg$ Kapitalen $\ll \mathrm{i}$ form af teorien om akkumulation, profit og kreditsystemet. Udover de konkrete historiske studier af kriserne, som hører hjemme på et andet og højere analyseniveau, som enten faseteori eller analyse af den nuværende kapitalisme, kan og bør Marx’s kriseteori gøres færdig på principplanet. At undlade at røre ved de ufærdige dele af hans teori, i stedet for at forsøge at gøre dem færdige, er ikke at vise respekt for »Kapitalens « videnskabelige resultater. Det er især vigtigt at fuldende Marx's overakkumulationsteori sammen med hans kreditteori, ikke kun for at kunne overvinde de afgørende begrænsninger i både den klassiske og den antiklassiske teori, men også for at skabe et sikkert teoretisk grundlag for analysen af kapitalismens modsigelsesfulde bevægelser med dens skiftende faser af $\varnothing$ konomiske og sociale kriser op gennem verdenshistorien og i vor tidsalder.

Oversat af Lotte Holm

\section{DEN JYSKE HISTORIKER, nr. 6}

\section{Om studiet af førkapitalistiske samfundsforhold}

Ud fra en præcisering og diskussion af betydningen af at studere førkapitalistiske og ikke-kapitalistiske samfundsforhold gennemgås en række aspekter af dette studium. Først diskuteres videnskabsteoretisk og videnskabshistorisk muligheden for at udforske førkapitalistiske samfundsforhold. Derefter opridses 3 hovedstrategier for dette studium, en teoretisk konstruktion ud fra arbejdsprocessen, ud fra ejendomsforholdene i snæver forstand og ud fra produktionsrelationerne i bredeste forstand. Til sidst analyseres to konkrete historiske situationer med henblik på at afklare mulighedsbetingelserne for en videnskabelig historisk analyse af prækapitalistiske samfundsforhold.

224 sider. Kr. 30,00.

Abonnement Nr. 5-8 incl.: Kr. 60,00.

\section{Forlaget MODTRYK}

Anholtsgade 48000 Aarhus C. TIf. (06) 1279 12, postgiro 5216478 


\section{KURASJES}

\section{BOGUDGIVELSER:}

Inger Bonnesen og Anne Thøger: Den kapitalistiske stat og dens funktioner. En bog om marxistisk statsteori. 176 sider; kr. 22.00.

Finn Hansson: Kapitalakkumulation, arbejderklasse og socialpolitik 95 sider; kr. 14,00.

Dieter Läpple: Staten og de almene produktionsbetingelser. 144 sider; kr. 17,00.

Introduktion til Kapitalens første bind. 224 sider; kr. 18,00.

Paul Mattick: Krise og arbejdsløshed. 120 sider; kr. 16,00.

Paul Mattick: Kriser og kriseteorier. 136 sider; kr. 17,00.

Dieter Otten: Kapitaludvikling og kvalifikationsudvikling. 200 sider; kr. 22,00.

Eugen Pasukanis: Almen retslære og marxisme. 124 sider; kr. 17,50.

Helmut Reichelt: Kapitalbegrebets logiske struktur hos

Karl Marx. 284 sider; kr. 28,00.

Morten Thing: Ideologier og litteratur.

142 sider; kr. 17,00.

Bøgerne kan købes i bogcaféerne eller ved indsættelse af de anførte priser på giro: 7166044 


\section{KAPITALREPRODUKTION OG \\ INDKOMSTPOLITIK}

STATENS OG FAGFORENINGERNES

INDFLYDELSE PÅ

\section{ARBEJDSLØNNEN}

\section{Jürgen Hoffmann og Willi Semmler}

I det følgende vil vi i teseform udvikle forholdet mellem $\varnothing$ konomi og politik i den udviklede kapitalisme, idet vi benytter indkomstpolitikken som eksempel. Herigennem inddrager vi den efter vor mening centrale konflikt i de kapitalistiske samfund, nemlig konflikten mellem lønarbejde og kapital. Denne konflikts konkrete udtryk, og de muligheder og grænser der er sat for det politiske systems »regulering « heraf gennem indgreb, kan imidlertid ikke analyseres, uden at man først gør sig den historiske sammenhæng klar. Derfor har vi forsøgt at forstå statsindgrebene, indkomstpolitikken (som del af disse statsindgreb) og lønarbejderorganisationernes stilling på baggrund af den vesteuropæiske kapitals historisk udviklede akkumulationsproces og de heri satte konflikter. Endvidere betragter vi dette arbejde som et forarbejde til yderligere undersøgelser af statens rolle i kapitalens akkumulationsproces samt at forholdet mellem stat og fagforeninger i den udviklede kapitalisme. 
Hvis man river sådanne unders $\varnothing$ gelser af forholdet mellem politik og $\varnothing \mathrm{ko-}$ nomi ud af den historiske sammenhæng, vil det medføre, at historisk tilfældige fænomener generaliseres ud over det tilladelige, og det vil kunne fă fatal praktisk betydning, hvis resultaterne af sådanne undersøgelser tages som udgangspunkt for politisk handlen. I modsætning hertil er det den kritiske videnskabs opgave, gennem dechiffrering af de empiriske forhold, at vise den historiske udviklings indre sammenhæng.

På grund af den begrænsede plads, der er til rådighed, kan dette i det følgende kun ske delvist og forkortet. Vores fremgangsmåde er følgende: I første del opdeles den vesteuropæiske kapitals akkumulations bevægelse i to faser, og der gives et alment rids af den voksende betydning, som statsindgrebene får for kapitalens reproduktionsproces fra et bestemt tidspunkt. Disse indgrebs muligheder og grænser bliver dernæst skitseret i anden del. I tredje del undersøges den økonomiske og politiske begrundelsessammenhæng for et udsnit af disse statsindgreb, nemlig indkomstpolitikken. I fjerde del unders $\varnothing$ ges indkomstpolitikkens virkninger på akkumulationsprocessen - først teoretisk og dernæst ud fra dens historiske gennemsættelsesf ormer i de vesteuropæiske lande. I femte afsnit forbindes den teoretiske og historiske sammenhæng, som er udviklet i de foregående afsnit, med en diskussion af forholdet mellem kapital, stat og fagforeninger.

\section{Om statsindgrebenes historisk udviklede be- grundelsessammenhæng i Vesteuropa}

En grov analyse af de vesteuropæiske landes udvikling siden anden verdenskrig gør det muligt at skelne mellem to faser i den vesteuropæiske kapitals akkumulationsbevægelse:

Den første fase, som er kendetegnet ved fremskyndet kapitaldannelse og kapitalakkumulation varer til omkring begyndelsen eller midten af 60'erne. I flere lande slutter den med den første alvorligere cykliske krise efter anden verdenskrig (Frankrig 1964; Italien 1964; Vesttyskland, Belgien og Holland 1966/67). Først vil vi kort beskrive denne fase.

Anden verdenskrig bet $\varnothing \mathrm{d}$ ligesom første verdenskrig en enorm tilintetgørelse, værdimindskning og ødelæggelse af kapital i såvel stoflig som værdimæssig form; på den anden side undgår man imidlertid en verdensomspændende stagnation, og der udvikler sig ikke heftige klassekampe, som det f.eks. skete efter første verdenskrig. Ud over tilintetgørelsen af kapital, udvidelse af de ydre afsætningsmarkeder, dvs. genoprettelse og udvidelse af verdensmarkedet, samt af totalarbejdskraftens kvalifikationer (jvf. Janossy 1966) er følgende to 
forhold af betydning for den fremskyndede akkumulation i de vesteuropæiske lande (også fremskyndet $\mathrm{i}$ forhold til USA):

a) en - i forhold til USA - enorm udvidelse af produktionspotenserne og

b) en langt større udbytning af det konsumerede arbejde, hvilket muliggør en betydelig stigning i den akkumulationsdygtige merværdi og akkumulationsraten.

Desuden spillede statsapparatet allerede fra begyndelsen af kapitalens fornyede akkumulationsbevægelse en langt større rolle for produktionspotensernes udfoldelse, for kapitalakkumulationen og for fastsættelsen af arbejdslønnen, end det havde været tilfældet i tiden efter første verdenskrig (jvf. f.eks. Hansen 1947 og 1957; Shonfield 1969; for Vesttyskland især Wallich; Altvater m.fl. 1973).

Ad a: De gennemsnitlige vækstrater var i perioden 1950 til 1962 for de nordvesteuropæiske lande 4,8\% og for Italien 6\%; for USA var de derimod kun på 3,3\%. Ifølge visse nyere undersøgelser (især Denison 1967) skyldes denne forskel kun i begrænset omfang den hastige teknologiske udvikling, uddannelsesudgifterne og totalarbejdskraftens kvalifikationer (hvilket Janossy antager), og den kan heller ikke i særlig grad tilskrives verdensmarkedets udbredelse. Forskellen skyldes snarere den kapitalistiske organisering af produktionspotenserne som storproduktion, afkapitalisering af småkapitalisterne samt opsugning af lønarbejdere, der enten er ubeskæftigede eller uproduktivt beskæftigede i produktionsgrene præget af mindre virksomheder eller indenfor landbruget, i produktionsgrene, som - tilskyndet af de nye efterspørgselsforhold - var præget af masseproduktion og produktion i stor skala (jvf. Denison 1967, s. 4f). Disse fænomener gælder især for Frankrig, Vesttyskland og Italien. På grund af sin tidlige blomstring (industrialisering og kapitalisering af produktionsbetingelserne - også indenfor landbruget - allerede i forrige århundrede) og sin nu svækkede stilling på verdensmarkedet kunne den britiske kapitalisme derimod kun i stærkt begrænset omfang udfolde sine produktionspotenser på lignende måde. Således var vækstraten for England i perioden 1950-62 i gennemsnit kun på 2,3\% (Denison 1967, s. 6).

I de vesteuropæiske lande foregår koncentrationen og den overvejende del af akkumulationen i produktionsgrene præget af masseproduktion, og der sker en centralisering af kapitaler. Dette er et resultat af de ovenfor beskrevne processer. Disse processer gør sig gældende i Frankrig og Vesttyskland samt i Italien, hvor der sker en ulige udvikling (regionalt) og hvor kapital og arbejde akkumuleres i den nordlige del af landet. Endvidere er statsindgrebenes tilsyneladende succes i Frankrig og Italien (samt i Vesttyskland i de første år efter valutareformen) blot et resultat af de ovenfor beskrevne sammenhænge.

$A d b$ : Kapitalistisk organisering af produktionspotenserne i samfundsmæssig skala, udvidelse af produktionspotenserne samt masseproduktion kan imidlertid ikke alene forklare den hurtige kapitalakkumulation. Man må yderligere inddrage arbejdets udbytningsgrad (eller - i mystificeret form - lønkvoten, jvf. afsnit $4.1 \mathrm{og}$ tillæg II) og dermed omfanget af den akkumulerbare merværdi, idet man under- 
søger ændringerne i disse to størrelser. Merværdiens størrelse afhænger i væsentlig grad af hvad lønarbejderne kan tilegne sig. Derfor er det akkumulationsdygtige merprodukt overvejende bestemt af reallønnens og lønkvotens bevægelser. (Lønkvoten vil kun kunne sættes lig med merværdiraten, hvis de uproduktive arbejdere, som ikke producerer merværdi, udelades af beregningen.) Lav lønkvote resp. høj merværdirate for den samfundsmæssige totalarbejdskraft betyder, når den relative andel af kapital, der omsættes til arbejdskraft, og arbejdets produktivkraft forbliver konstante, at gennemsnitsprofitraten for den samfundsmæssige totalkapital vil være $h ø j$. For visse vesteuropæiske lande (først og fremmest Italien og Vesttyskland og med forbehold også Frankrig) gælder det, at reallønnen og lønkvoten efter anden verdenskrig frem til begyndelsen af 60'erne kunne holdes på et lavt niveau som følge af en stor overskydende arbejderbefolkning, dvs. en stor industriel reservearmé. Dette blev yderligere i nogle lande understøttet af fagforeningernes tilbageholdenhed i lønkampen. Således fastslår Kindleberger (1967, s. 8): »Sålænge der eksisterer overskydende arbejdskraft, går vækstprocessen videre som følge af store profitter, reinvesteringer og stigende arbejdsproduktivitet samt konstante lønninger ... Når udbuddet af arbejdskraft falder, indebærer voksende kapitaldannelse $\mathrm{i}$ industrien, at lønningerne stiger; endvidere kan der ske et fald i profitterne. Lønandelen af indtægterne vokser. Profitterne og investeringernes vækst standser. Dermed ophører stigningen i efterspørgslen efter arbejde, hvilket ændrer vækstprocessens karakter.«

Reallønnens og lønkvotens stigning i 60'erne finder næsten sted samtidig i Frankrig, Vesttyskland og Italien (se tillæg I) (for England gælder dette kun i begrænset omfang). Denne udvikling sker på grund af et stærkt fald i den overskydende arbejderbefolkning samt i den industrielle reservearmé, hvilket skal ses på baggrund af en blomstrende kapitalakkumulation.

Man må imidlertid også bemærke, at arbejdsproduktiviteten på den ene side stiger stærkt i alle de nævnte lande indtil begyndelsen af 60'erne, mens reallønnen på den anden side kun stiger i beskedent omfang. Dermed sker der en forstærket udbytning og en vækst i det akkumulerbare merprodukt resp. profitten (jvf. Kindleberger 1967, s. 25). Denne enorme udbytning af lønarbejderne i akkumulationsbevægelsens første fase kan (ifølge Kindleberger) fuldt ud sidestilles med den industrielle revolution i England i første halvdel af det 19. århundrede: »Det, der foregik i Europa efter anden verdenskrig, var i virkeligheden den samme proces« (Kindleberger 1967, s. 25).

Allerede i den fornyede kapitalakkumulations første fase spillede statsapparatet en vigtig rolle ved bestemmelsen af det akkumulerbare merprodukts omfang: f.eks. gennem begrænsning af arbejdslønnen og politisk pres på fagforeningerne (dette gælder især for Italien og Vesttyskland; jvf. for Italien Salvati 1972 og CGIL/CISL 1973; for Vesttyskland kan man som eksempel nævne diskussionerne om medbestemmelse, som fandt sted fra begyndelsen af 50'erne). Endvidere skete der en statslig forcering af kapitalakkumulationen ved hjælp 
af statsbudgettet og skattesystemet, gennem særlig gunstige afskrivningsregler, rentebegunstigede genopbygningskreditter, investeringsfinanciering og investeringsprogrammer (for Vesttyskland se Wallich 1955, Reuss 1963, Roskamp 1965). Det britiske landbrugs tidlige kapitalisering hæmmede frisættelsen af arbejdskraft fra ikke-kapitalistiske sektorer i Storbritannien og dermed fremvæksten af en industriel reservearmé. Endvidere var det her ikke muligt i samme udstrækning som i Frankrig (tilbagevandring fra kolonierne) og Tyskland (flygtningestrømmen) at hente et arbejdskrafttilskud fra andre kilder. Også hvad dette andet vigtige moment i kapitalakkumulationen i Vesteuropa angår, afviger de britiske forhold altså fra forholdene i Frankrig, Italien og Vesttyskland. Det var således ikke muligt for den britiske kapitalisme at presse arbejdslønnen på samme måde, som vi har kunnet iagttage i de andre lande. (Af denne grund prøver man i Storbritannien langt tidligere end i de andre her nævnte lande at begrænse lønnen gennem en statslig indkomstpolitik; jvf. United Nations 1967, Ch. IV.) Samtidig blev Storbritanniens stilling på verdensmarkedet forværret, idet de britiske varers verdensmarkedspriser steg på grund af produktionspotensernes formindskede udfoldelse og udvidelse (tilvæksten i arbejdsproduktivitet var mindre i Storbritannien end i de andre lande). Dermed satte også realiseringsmulighederne grænser for kapitalakkumulationen.

I Vesteuropa startede kapitalakkumulationens anden fase i begyndelsen eller midten af 60'erne - med forskelle fra land til land. Vi kan til at begynde med konstatere, at såvel reallønnen som lønkvoten steg i alle vesteuropæiske lande (jvf. Dall'Asta 1971, s. 20ff; Kindleberger 1967; tillæg I). Dette var en følge af den forudgående blomstrende kapitalakkumulation og den dermed udvidede efterspørgsel efter arbejdskraft, som indebar opsugning af den overskydende arbejderbefolkning og voksende forhandlingsstyrke for fagforeningerne fra slutningen af 50'erne. Med stigende lønkvote formindskedes den akkumulationsdygtige merværdi (eller profitmassen og profitraten faldt). Allerede af den grund måtte akkumulationen blive mindre (jvf. Mandel 1972, 5. kapitel).

Den stigende lønkvote (eller lønarbejdernes stigende andel af udviklingen af arbejdets produktivkraft) formindskede kapitaldannelsen. Alligevel var den ikke årsag til den kapitalistiske krise, som på dette tidspunkt kunne anes $^{1}$. Tværtimod må man fastholde, at der skete en stigning $\mathrm{i}$ kapitalens organiske sammensætning og herigennem et fald i værdiøgningsgraden som følge af den fremskyndede kapitalakkumulation og stigningen i arbejdets produktivkraft, dvs. som følge af de processer vi tidligere har beskrevet (hvilket let kan påvises ved hjælp af tilgængelige indikatorer for de enkelte

1. Således som det ofte hævdes af $\varnothing$ konomer og fungerende kapitalister. Samme synspunkt findes hos E. Mandel: Der Spätkapitalismus, kapitel 5, selv om han andre steder fremstiller sammenhængen korrekt. 
lande ${ }^{2}$ ). Man kan imidlertid ikke direkte udlede krisen af denne tendens; her skal vi kun give et rids af de konflikter i de nationale kapitalers reproduktionsprocesser, som var udgangspunkt for den statslige indflydelse på kapitalens og arbejdets reproduktionsbetingelser. Kernen i de konflikter, som viste sig i Vesteuropa ved slutningen af kapitalakkumulationens første fase, synes at være det forhold, at det på den ene side på grund af den stigende organiske sammensætning er nødvendigt med en voksende anvendelse af kapital for at producere en passende profit. Dette kan (neo-klassisk) udtrykkes således: »Kapitalfaktoren er blevet forøget i forhold til faktoren arbejde« (Sachverständigenrat 1973, s. 57). På den anden side fremmes disse tendenser, idet den samme proces, - som antydet ovenfor - medfører en stigning i reallønnen, hvilket sætter yderligere grænser for profitproduktionen. (Se om Vesttyskland Altvater/Hoffmann/Schöller/Semmler 1974 og landerapporterne om Vesteuropa i Altvater/Brandes/Reiche 1975).

Det var disse - her blot antydede - modsigelsesfyldte tendenser, som i de forskellige lande betød at cykliske kontraktionsprocesser og kriser gjorde sig stærkere gældende i denne periode. Gennem braklægning af kapital og den industrielle reservearmés fornyede fremvækst (selv om den kun i ringe grad var synlig) opstod der nu mulighed for at foretage nyinvesteringer i forbedret maskineri, at anvende forbedrede arbejdsmetoder (arbejdsintensivering) og indføre fast kapital i ny teknologisk form ${ }^{3}$.

I løbet af det videre akkumulationsforl øb blev det i 60'erne stadig mere klart, at kriserne ganske vist for en tid kunne formidle de nævnte tendensers modsigelsesfyldte karakter; men på den anden side reproducerede de blot modsigelserne i udvidet skala i form af perioder præget af stagnationstendenser (som følge af almen overproduktion og overakkumulation). Disse stagnationsfaser i

2. I denne forbindelse kan man ganske vist kun med visse forbehold slutte ud fra den stigende kapitalintensitet og den stigende kapitalproduktivitet. Til anskueliggørelse gengiver vi her følgende oversigt over kapitalrentabiliteten i det vesttyske erhvervsliv (efter Görzig m.fl. 1973, s. 45):

$\begin{array}{lcc}\text { Kapitalrentabilitet i \% af nettoinvesteringer og afskrivninger } \\ \text { Tidsrum } & \text { i genanskaffelsespriser } & \text { i købspriser } \\ 1954-1960 & 21,5 & 25 \\ 1960-1964 & 17,0 & 21 \\ 1964-1970 & 13,5 & 17\end{array}$

En undersøgelse fra Hoppenstedt-Verlages (Darmstadt) kommer til samme resultat gennem en analyse af kapitalrentabilitet, omsætningsrentabilitet og cash-flow for de 40 største vesttyske aktieselskaber (jvf. Handelsblatt 27/28-10-1972 og følgende numre). Den faldende rentabilitet er fra 1968 for enkeltkapitalerne ledsaget af stigende gæld. (Angående faldende rentabilitet se også Gutachten des Sachverständigenrats 1973, s. 57).

3. Når f.eks. regeringens krisekommission taler om et produktivitetsvidunder (efter 1967 stiger rentabiliteten generelt indtil 1969 uden dog at nå de oprindelige stigningsrater), er det et udtryk for dette forhold. Jvf. Sachverständigenrat 1969, pkt. 52-54. 
kapitalakkumulationen (hvilket f.eks. klart viste sig i England) var ledsaget af underbeskæftigelse og arbejdsløshed samtidig med vedvarende prisstigninger (og der udvikledes frie kapitalmasser, som valutaforholdene kastede omkring).

Den proces, som vi her har beskrevet (dvs. stagflationstendensernes fremtræden eller latente eksistens) bevirkede, at staten i denne fase forstærkede sin indflydelse på kapitalens reproduktion. Den første fase i den vesteuropæiske $\varnothing$ konomiske udvikling var væsentligst bestemt af produktionspotensernes og akkumulationens udfoldelse og kun i ringere grad af overvindelsen af denne udviklings immanente grænser (som f.eks. gennem en statslig udvidelse af efterspørgslen - jvf. Hansen 1947 og 1957). I den anden fase synes den kapitalistiske organisering af de således udviklede produktionspotenser og dermed den kapitalistiske begrænsning af produktionens videre udvikling (begrænsning af merværdi (profit) produktionen set i forhold til den udlagte kapital og begrænset realisering af den producerede merværdi) i stadig større grad at blive det vigtigste problem (jvf. OECD 1970a; OECD 1970b, punkt 6-12)

\section{Om statsindgrebenes form og grænser i den udviklede kapitalisme}

Den begyndende stagnation i kapitalakkumulationen resulterede i forstærkede statsindgreb. Med udgangspunkt i hvad vi hidtil har udviklet vil vi nu opstille baggrunden for statsindgrebene. Statens indflydelse på reproduktionsprocessen udviklede sig historisk og den var i reglen orienteret i retning af den keynesianske resp. post-keynesianske teori. Dens almene funktion var at lette produktion og realisering af merværdi med henblik på sikring af nye kapitalinvesteringer og en fornyet kapitalakkumulation. Vi kan - med udgangspunkt i den marxistiske kritik af den politiske $\varnothing$ konomi - sammenfatte de af staten anvendte midler under tre centrale punkter (for en nøjere behandling se Semmler/Hoffmann 1972).

De kan have til formål

a) gennem en øgning af den effektive efterspørgsel at sætte enkeltkapitalerne i stand til at realisere en del af den genstandsgjorte værdi og merværdi.

4. Disse tendenser viste sig først i de lande, hvis stilling på verdensmarkedet var svækket (som England, mens Vesttyskland endnu i vidt omfang kunne externalisere disse konflikter). løvrigt forsøger vi ikke her at opstille sammenbrudsprognoser, men derimod at analysere de udviklede konflikter i reproduktionsprocessen og disse konflikters formidlinger. Ændrede betingelser for profitproduktionen er således udgangspunkt for modificerede statsindgreb, ændret penge- og kreditpolitik, som igen kan virke tilbage på de oprindelige betingelser. Statsindgrebene forbliver imidlertid begrænset af de almene reproduktionsbetingelser. En exemplarisk fremstilling heraf findes hos Lindner 1973. 
Dette kan ske gennem offentlige investeringer, udlicitering af offentlige arbejder og beskæftigelsesprogrammer, ved at $\varnothing$ ge efterspørgslen efter konsumvarer gennem forbrugssubventioner (hvilket sjældent er sket historisk) eller gennem en omfordeling af indkomsterne over skattesystemet.

b) at forhøje værdiøgningsgraden (profitraten). Dette kan ske ved billiggørelse af den konstante kapitals elementer (hjælp til fremskaffelse af billigere råstoffer, gunstigere afskrivningsregler, påbud om prisstop), ved at $\varnothing$ ge de fungerende kapitalers samlede profitmasse gennem almene lønsænkninger (som vi senere skal vise, opfylder en inflation, som bl.a. skyldes udvidelse af statsgælden, samme funktion mht. sænkning af reallønnen) ved at forøge den arbejdstid, der kan genstandsgøres (med samme eller et større antal produktive lønarbejdere), eller det kan endelig ske ved at sænke skattebyrden på den samlede profitmasse.

c) at formindske den samfundsmæssige totalkapital (dvs. den størrelse, som den samfundsmæssigt disponible profitmasse skal sættes i forhold til). I krise- og stagnationsfaser muliggør dette en fornyet akkumulation efter en fremskyndet eller fremtvunget værdimindskning af kapitalen.

Statsindgrebene skyldes, at vanskelighederne og konflikterne i kapitalens samfundsmæssige reproduktionsproces tilspidses, hvilket finder udtryk i braklægning af kapital og arbejdskraft på grund af kapitalens manglende profitabilitet. De fremkommer imidlertid ikke som et umiddelbart svar på disse problemer. Derimod bliver de sat igennem formidlet via politiske bevægelser, hvis indhold bestemmes af bærernes materielle interesser. På den anden side begrænses statens indgreb af kapitalreproduktionens lovmæssigheder. I det følgende skal vi give en antydning af disse grænser, som i øjeblikket fremtræder i den økonomiske politiks dilemma, som består i på samme tid at sikre blomstrende kapitalakkumulation, fuld beskæftigelse og prisstabilitet (angående det følgende se Mattick 1973; Altvater 1973, s. 46-54 og Semmler/Hoffmann 1972, s. 60-69):

1) De statslige midler til sikring af en stadig kapitalakkumulation må på længere sigt atter slå om i en begrænsning af akkumulationen. De monetære midler, hvormed staten kan $\varnothing$ ge den samlede effektive efterspørgsel, fremskaffes enten ved udskrivning af skatter, ved lån på kapitalmarkedet eller ved »at lade seddelpresse køre«. Statsindgreb, der har til formål at øge den samlede effektive efterspørgsel, vil kun medføre en fornyet kapitalakkumulation, hvis »arbejdsgivernes indkomster «, dvs. de realiserede profitter, atter stiger (jvf. Keynes 1936, især den teori om kapitalens grænsenytte, som han udvikler i kapitel 11. Se også Keynes 1940). Dette er imidlertid kun muligt gennem en stigning i de samlede udgifter - især i de offentlige udgifter. Denne metode - Øgning af de offentlige udgifter (f.eks. gennem underskud på statsbudgettet (»deficit spending «)) - har imidlertid også en bagside: Underskudsfinancieringen må ske gennem statslig låntagning; overfor den stigende profit, som er delvis fiktiv, står en akkumulation af statsgæld. Til denne statsgæld svarer en belastning af en offentlige husholdning i form af renter (angående »monetære restriktioner« 
på den statslige planlægning se Ronge/Schmieg 1973). Derfor vil en stadig større del af nationalproduktet koncentrere sig hos de, der ejer statsgældsbeviser; på den anden side må staten klare den stigende rentebyrde gennem fornyet låntagning eller ved hjælp af skatteforhøjelser. Under forudsætning af, at skatteforhøjelserne ikke udelukkende lægges på arbejdslønnen, betyder det, at den akkumulerbare merværdi begrænses, hvilket samtidig begrænser kapitalakkumulationen. Endvidere indebærer den voksende statsgæld, at der dannes fiktiv kapital; statsgældsbeviser cirkulerer uden at modsvare real værdi, og de udgør en kilde til permanent inflation ${ }^{5}$.

2) Ligesom når staten udvider den effektive efterspørgsel, sker der ved udvidelsen af den offentlige sektor en begrænsning af akkumulationen på længere sigt (som når f.eks. de offentlige investeringer, som foregår komplementært til den private kapitaldannelse, udvides). I den offentlige sektor sker der ingen værdiøgning af kapital, med mindre staten fungerer som reel kapitalist. Der sker altså ingen værdiøgning formidlet gennem produktivt lønarbejde; den offentlige sektor udgør tværtimod et fradrag fra samfundets akkumulations- og konsumtionsfond. Dette fradrag sker gennem skattesystemet eller gennem offentlige institutioners kredittagning. I forhold til den totalsamfundsmæssige reproduktionsproces udgør den offentlige sektor udelukkende konsumtion; den forøger hverken kapitalens stoflige eller værdimæssige form (hvilket ikke betyder, at kapitalens reproduktion ikke fremmes ved sikringen af f.eks. materielle produktionsbetingelser; for en nøjere behandling af dette problem se Läpple 1973) ${ }^{6}$. Den offentlige sektors

5. Det er forenklet, når man ensidigt forklarer inflationen med udvidelsen af den statslige virksomhed (og dermed udvidelsen af statsgælden). Vi skal her nævne nogle aspekter, der ville være relevante for en videre unders $\varnothing$ gelse, idet vi ser bort fra, at den almene sammenhæng skulle fremstilles teoretisk på grundlag af en udledning af den rentebærende (låne-) kapital og historisk som en analyse af de ændrede betingelser for kapitalens reproduktionsproces siden 30'erne. Hvis man generelt (med Marx) kan gå ud fra, at pengemængden tilpasser sig varecirkulationen (i modsætning til kvantitetsteorien), og at varecirkulationen kun udgør kapitalreproduktionens overflade, må prisstigningerne og den deraf følgende udvidelse af mængden af cirkulationsmidler forklares på grundlag af kapitalreproduktionen. Det er altså kapitalreproduktionen, der skaber udbud- og efterspørgselsforholdene og frisætter kapital i pengeform, hvad enten det sker transitorisk eller langsigtet. Det er pengebevægelsens sammenhæng med kapitalbevægelsen, som kan forklare at produktions- og cirkulationskreditter samt statslige gældsbeviser (der delvis cirkulerer uden at modsvare nogen real værdi) indebærer udvidede krav på den producerede nyværdi og dermed udgør kilder til inflationen. Hvis man derimod betegner løntilvæksten som inflationskilde, ser man bort fra den kapitalistiske reproduktionsproces' natur, hvilket let kan vises ved det forhold, at der også uden lønstigninger forekommer inflatoriske processer. Jvf. Semmler/Hoffmann 1972, s. 69-82.

6. Denne sammenhæng ligger til grund for W. Vogts undersøgelse af det kapitalistiske systems langsigtede $\emptyset$ konomiske udvikling. Efter at Vogt ved hjælp af den »neo-klassiske« vækstteori har udelukket modsigelsen mellem kapitalakkumulation og værdiøgning af sine videre overvejelser og dermed ophævet den kapitalistiske udviklings modsigelsesfulde karakter ved hjælp af »det tekniske fremskridt«, står kun modsigelsen mellem den private og den statslige sektor tilbage som konfliktgrundlag. Jvf. Vogt 1973, s. 161-188. 
uproduktive opsugning af arbejdskraft og produktionsmidler kan således ikke foregå ubegrænset; sagt på en anden måde: den private kapitaldannelse kan ikke indsnævres ubegrænset. Udvidelse af den offentlige sektor betyder, at den akkumulerbare merværdi begrænses i sin stoflige form, dvs. at der sker en indskrænkning i akkumulationen af produktionsmidler og arbejdskraft som kapital. En sådan udvidelse må derfor også fremkalde en reaktion fra kapitalens side og producere konflikter omkring statens rolle ${ }^{7}$.

3) Kapitalreproduktionens immanente modsigelser udvikler sig med kapitalens fortsatte, statsligt stimulerede akkumulationsbevægelse, og kapitalens grænser må nødvendigvis på ny fremtræde som et fald i værdiøgningsgraden og overakkumulation af kapital sammen med underbeskæftigelse. Staten kan kun formidle modsigelserne hvis den foretager stadig mere omfattende indgreb. De enkelte nationale kapitaler kan ganske vist for en tid udskyde det punkt, hvor statsindgrebenes (immanente) grænser gør sig gældende. Disse grænser, som er sat af kapitalreproduktionens lovmæssigheder, kan således udskydes så længe, en ydre ekspansion (på verdensmarkedet) muliggør, at den overskydende kapitalværdi (varekapital) og den deri indeholdte merværdi realiseres. Hvis der imidlertid alment optræder overakkumulationstendenser på verdensmarkedet, er det ikke længere muligt at eksternalisere modsigelserne i den nationale kapital; statsindgrebenes grænser må så fremtræde tydeligere. Det samme gælder generelt for grænserne for kapitalens akkumulationsbevægelse. (Idet vi ikke her betragter en enkelt national kapital, men et overnationalt $\varnothing$ konomisk område - Vesteuropa -, vil vi i det følgende ikke yderligere behandle verdensmarkedets modificerende indflydelse; for så vidt de gensidigt opnåede fordele og ulemper ophæver hinanden indenfor dette område - her ser vi bort fra USA og Japan - betragter vi denne metode som metodisk retfærdiggjort.) ${ }^{8}$.

Statens muligheder for ved hjælp af statslig ( $\varnothing$ konomisk) politik at $\varnothing v e$ indflydelse på kapitalens værdiøgningsbetingelser er således begrænsede. På den anden side er staten - under trussel om alvorlige politiske konflikter - tvunget til overfor mulige stagnationstendenser (nemlig sådanne tendenser, som i begyndelsen af 30'erne

7. Dette kan illustreres ved diskussioner om financieringen af de »indre reformer«. I det hele taget har som Kalecki (1943) betoner - kapitalistklassen en generel mistillid til statsindgreb, som altid i en vis forstand må berøre den private kapitals værdiøgning. Således blev det især indvendt mod forsøgene på at føre fuld-beskæftigelses-politik, at arbejdsløshedens disciplinerende virkning ville forsvinde, og at arbejderklassens selvbevidsthed ville blive forstærket. Det har således - ifølge Kalecki - netop været den tyske fascismes funktion at udrydde sådanne betænkeligheder ved en statslig fuldbeskæftigelses-politik ved at knuse arbejdernes organisationer - en tese, som i mellemtiden er blevet fuldt ud bekræftet af Sohn-Rethels detaljerede undersøgelser (jvf. Sohn-Rethel 1973 og Kadritzke 1973, s. 122ff). Vi vil senere få at se, hvorledes disciplinering af arbejderorganisationerne også ledsager den aktuelle fuld-beskæftigelses-politik.

8. Dette gælder også diskussionen af de forskellige former for indkomstpolitik i afsnit 4.1. Vi vil altså ikke senere inddrage en ændring af terms og trade i unders øgelsen. Angående de mulige virkninger af ændrede bytteforhold (fra et materialistisk synspunkt) se Schöller 1973. 
fremtrådte som strukturelle konflikter i den højt udviklede kapitalisme) permanent at sikre et højt akkumulationsniveau og dermed fuld beskæftigelse, hvilket kan ske gennem statslig efterspørgsel eller manipulering af pengemængden. Således som statsindgrebene har udviklet sig siden verdenskrisen som svar på det udviklede overakkumulationsdilemma, er de i deres specifikke indhold et resultat af kapitalens udvikling i den forstand, at kapitalen allerede er stødt på sine egne skranker, og at disse kun lader sig udskyde ved hjælp af ydre momenter. På den anden side viser det sig tydeligt $\mathrm{i}$ en stagnationsperiode hvor kapital og arbejdskraft ligger brak, at det kapitalistiske system i bestemte faser er ude af stand til at sikre beskæftigelsen og dermed den eksisterende arbejdskrafts reproduktion. Med den manglende profitabilitet og tilvæksten i den industrielle reservearmé er der således skabt et grundlag for politiske konflikter, som tvinger staten til »at gribe ind « $i$ kapitalens reproduktionsproces?.

Statens indflydelsesmuligheder er immanent begrænsede (som vi tidligere har antydet); imidlertid er der ikke sat lignende immanente grænser for det umiddelbare tryk på arbejdslønnen. Under de angivne politiske og økonomiske forhold forsøger staten i konsekvens heraf at opretholde kapitalens værdiøgningsgrad ved at trykke reallønnen (mere herom hos Krelle 1972 og Haberler 1972). Løsningen på konflikten bliver på ny - som i den klassiske teori før Keynes - en ydre begrænsning af arbejdslønnen ${ }^{10}$.

\section{Indkomstpolitikkens økonomiske og politiske årsager ${ }^{11}$}

Det er allerede (i den historiske skitse) blevet antydet, at der findes bestemte faser i den industrielle cyklus, i hvilke lønstigningens omfang er af særlig betyd-

9. Når vi benytter udtrykket »at gribe ind «, er det for at tydeliggøre, at der er tale om forstærket statslig indflydelse. Naturligvis udgør staten altid et moment i den totalsamfundsmæssige reproduktionsproces. Derfor er det heller ikke holdbart at fremstille forholdet mellem stat og borgerligt samfund som et ydre forhold (en sådan opfattelse er udgangspunkt for »agenturteorier « og for teorier, som går ud fra den statslige sfæres autonomi).

10. Vi forholder os her til Marshall, Hicks og Pigou, som - med udgangspunkt i den klassiske »lønfondteori« og på grundlag af grænseproduktivitetsteorien - gør opnåelsen af fuld beskæftigelse afhængig af reallønnens højde. Jvf. Pigou 1933.

11. Ved indkomstpolitik vil vi i det følgende forstå lønpolitik eller lønbegrænsning. Dette er berettiget, fordi lønpolitik sammen med priskontrol - bortset fra forsøgene på udbyttekontrol i 1948/49 og 1966/67 (jvf. IfS-Zwischenbericht 1969, s. 28) - har været det væsentligste indkomstpolitiske middel. I afsnit 4.1 vil vi påvise, hvorfor priskontrol ikke nødvendigvis er det samme som profitkontrol. På den anden side vil vi ved fremstillingen af indkomstpolitikkens historiske gennemsættelsesformer være nødt til at udvide dette begreb til også at omfatte indgreb på arbejdsmarkedet. 
ning for værdiøgningsprocessens flydende forløb (selv om enkeltkapitalisterne naturligvis til stadighed må forsøge at holde lønnen - betragtet som omkostningsfaktor - på så lavt et niveau som muligt). Ved hjælp af nogle teoretiske overvejelser vil vi her endnu engang tydeliggøre denne sammenhæng.

Med akkumulationsprocessens udvikling i løbet af den industrielle cyklus (nærmere bestemt i den begyndende højkonjunktur) sker der, samtidig med at den udlagte kapitalværdi vokser og arbejdets produktivkraft $\varnothing$ ges, en relativ formindskelse af den kapitaldel, som omsættes i arbejdskraft. Dette medfører et cyklisk fald i profitraten, selv om merværdimassen og dermed profitmassen endnu vil kunne $\varnothing$ ges gennem opsugning af yderligere arbejdskraft og stigendende merværdirate (som følge af intensivering og stigning i arbejdets produktivkraft). Hvis den disponible arbejdsmasse er udtømt, hvis merværdiraten ikke kan $\emptyset$ ges yderligere og hvis arbejderne endog er i stand til at gennemtrumfe højere arbejdsløn på grund af stigende efterspørgsel efter arbejdskraft, begrænses væksten i den samlede merværdimasse og akkumulationen må aftage. Lønstigningernes omfang kan altså have betydning for højkonjunkturens varighed og kontraktionsprocessens voldsomhed. Men krisens indtræden skaber selv grundlaget for et nyt opsving. Det sker ved at dele af den samfundsmæssige totalkapital lægges brak og/eller værdimindskes, og ved at udvidelsen af den industrielle reservearmé på ny sænker arbejdslønnen og øger merværdiraten. Arbejdslønnen er her blot en af flere forudsætninger for et fornyet opsving; det er ikke arbejdslønnens bevægelse, men derimod kapitalens bevægelse, der gør den industrielle cyklus til en krisecyklus; arbejdslønnen er afhængig variabel i forhold til kapitalakkumulationen!

Vi har nu i store træk skitseret arbejdslønnens betydning for den (»klassiske«) industrielle cyklus, især dens betydning for kontraktionsprocessens voldsomhed. Arbejdslønnen kan imidlertid få en permanent betydning, som rækker ud over den (nu modificerede) industrielle cyklus. Det sker i historiske faser, hvor de cykliske kriser på grund af almen overakkumulation ikke længere er i stand til at opfylde deres »funktion «, som er at skabe grundlaget for et nyt opsving,og hvor den statslige »fuld-beskæftigelsespolitik« derfor må sikre en vellykket akkumulation. En kontraktionsproces skal forhindres; akkumulationen skal fastholdes som »quasi-boom « (Keynes) ved hjælp af udvidet brug af penge- og finanspolitik. En permanent ydre begrænsning af lønnen er klart nødvendig, når man anvender disse midler, hvis almene grænser vi allerede har udviklet. I den klassiske krisecyklus tilpassedes arbejdskraftens pris til akkumulationens behov gennem den industrielle reservearmés latente eksistens. Denne automatiske mekanisme bliver sat ud af kraft gennem den statslige fuldbeskæftigelses-politik, thi opretholdelsen af den fulde beskæftigelse styrker lønarbejderorganisationernes, dvs. fagforeningernes, forhandlingsposition, således at de tilsyneladende kan presse lønniveauet i vejret (og dermed presse merværdiraten ned, hvis den højere løn ikke kompenseres af højere pri- 
ser. (Fagforeningernes postulerede »monopolstilling « må derfor hyppigt i den populærvidenskabelige litteratur holde for som forklaring på inflationen; jvf. Haberler 1972 og Machlup 1971). Hvis den statslige økonomiske politik og fagforeningernes hhv. arbejdsgiverforeningernes magt var bestemmende for akkumulationsprocessen på den her antydede måde, kunne man faktisk med Kalecki tale om, at en »business-cycle« var blevet afløst af en »political-business-cycle«, idet det politiske niveau (her snævert forstået som modsætningen mellem statsapparat og organisationer) tilsyneladende var blevet bestemmende for dens samfundsmæssige udvikling.

En sådan illusion har sin materielle begrundelse $\mathrm{i}$ det forhold, at modsigelserne i bestemte akkumulationsfaser endnu ikke har tilspidset sig (dette har vi påvist i første afsnit), hvilket indebærer at statsindgrebenes virkning på akkumulationsbevægelsen tilsyneladende er særdeles effektiv. Den statslige indflydelse kan imidlertid ikke bestemme akkumulationsprocessen, men kun virke modificerende på den. De immanente (overakkumulations-)tendenser ophæves ikke; de udskydes blot. Stagnationstendensernes fornyede optræden fra slutningen af 60'erne / begyndelsen af 70'erne i form af »stagflation« viser statsindgrebenes historiske begrænsning.

Overvindelsen af sådanne stagnationstendenser forudsætter - ud over et fald i den udlagte kapitalmængde - en passende øgning af merværdien og dermed en passende (relativ) lønsænkning ${ }^{12}$. I stagnationsperioder bliver arbejdslønnen således atter et centralt konfliktpunkt, idet de andre statslige midler (statslig efterspørgsel, kreditudvidelse etc.) er skabt med henblik på at fremme akkumulationen og overvinde underbeskæftigelsen. Sådanne statsindgreb sætter imidlertid gang i inflationen; stagflation er således et ydre udtryk for statens immanente grænser i forhold til akkumulationsprocessen.

Inflationen har ganske vist den objektive virkning, at den sænker reallønnen, hvilket - totalsamfundsmæssigt - фger merværdiraten (jvf. bl.a. Keynes 1936, s. 6ff). For så vidt er det altså berettiget at tale om inflationen som »substitut for den industrielle reservearmé« (jvf. Müller-jentsch 1973, s. 230). På den anden side udvikler lønarbejderne med det stadig større fald i pengenes værdi en reallønsbevidsthed, og de begynder i lønkampen at kræve dækning for hvad de mister gennem forringelsen af pengenes værdi. Ved at tolerere eller fremme de inflatoriske processer ${ }^{13}$ bringer staten sig ikke blot i modsæt-

12. Denne sammenhæng kan forklare det konstaterede mindre spillerum for kapitalens indrømmelser i lønforhandlinger i de senere år i Vesteuropa. Naturligvis har kapitalen mulighed for at forhøje merværdiraten på andre måder end ved at trykke arbejdslønnen. Den kan således intensivere arbejdet, $\varnothing$ ge produktivkraften etc., men dette vil blot fremme de immanente konflikter.

13. At tale om en »strategi« for reallønsænkning gennem inflation, som det gøres i fagforeningsteoretiske overvejelser, der forholder sig til monopolkapitalisme-teoremet, er fejlagtigt allerede af den grund, at reallønsænkningen udelukkende virker totalsamfundsmæssigt mens de enkelte kapitaler rammes forskelligt heraf afhængig af branche (selv om inflation begunstiger de store kapitalers akkumulation). 
ning til lønarbejderne, som kun gennem lønkampen kan opnå kompensation for løntabet; en sådan politik kommer også i konflikt med (stor-)sparernes og rentierklassens interesser, for hvem en sådan kompensationsmulighed ikke eksisterer. Når den rate, hvormed pengene falder i værdi, overskrider et bestemt niveau, vil det forstyrre selve kapitalakkumulationen. (Endelig rammer inflationen den kapital, der skal lægges ud; især de mindre »kapitalstærke« kapitaler og de kapitaler, der har en lang omslagstid, bliver forfordelt eller trues af undergang i konkurrencen.)

Sænkning af reallønnen gennem permanent inflation (som Keynes anbefalede) er således et tvivlsomt middel såvel økonomisk som politisk (og det kan heller ikke i praksis »håndteres « af staten - jvf. fodnote 5). Hvis staten fors $\emptyset$ ger at føre fuld-beskæftigelsespolitik, gør akkumulationsprocessens immanente konflikter det stadig mere nødvendigt med et udefra kommende løntryk i løbet af den videre akkumulationsbevægelse. Man formoder således, at statslige forsøg på lønbegrænsning er en vej ud af de højtudviklede kapitalistiske staters dilemma: »Den stabilisering, som man opnår gennem den moderne $\varnothing$ konomiske politik, må betragtes som et fors $\varnothing \mathrm{g}$ på, gennem en manipulering af investeringskvoten ved hjælp af statslige investeringer, permanent at sikre den fulde beskæftigelse sammen med en tilfredsstillende profitrate. Her hjælper en fleksibel pengepolitik, som på den ene side muliggør, at reallønnen holdes på samme niveau, selv om pengelønnen stiger, og som på den anden side, uden i væsentligt omfang at true den fulde beskæftigelse, iværksætter en restriktiv kreditpolitik, når inflationen truer med at tage overhånd. Idet der her opstår en modsigelse mellem behovet for at holde inflationen indenfor visse grænser og nødvendigheden af ikke at standse investeringsprocessen, har staten i de senere år i øget omfang grebet til indkomstpolitiske foranstaltninger.« (Schefold 1973, s. 166) ${ }^{14}$.

Vi kan således sammenfatte resultatet af vore overvejelser således: Den permanente anvendelse af keynesiansk orienterede instrumenter i den statslige $\varnothing \mathrm{ko}$ nomiske politik under de angivne historiske betingelser for kapitalakkumulationen i 60'erne og begyndelsen af 70'erne fremtvinger lidt efter lidt anvendelsen af det klassiske (før-keynesianske) middel - ydre begrænsning af lønnen ${ }^{15}$.

14. Vi mener ganske vist, at staten slet ikke har en sådan valgmulighed, som Schefold opstiller, og at det netop er her det substantielle problem ligger.

15. Vi har hidtil forsøgt at udlede indkomstpolitikken af de udviklede konflikter i reproduktionsprocessen. Hvis man heroverfor fremhæver tvangen til intern virksomhedsplanlægning på grund af den enorme tilvækst i den faste kapital som årsag til de statslige indgreb i konflikten mellem lønarbejde og kapital, har man ganske vist peget på en betydningsfuld sammenhæng, som især angår de store kapitalers umiddelbare interesser. Denne sammenhæng forklarer imidlertid ikke statsindgrebene som alment fænomen ud fra den totalsamfundsmæssige reproduktionsproces. 


\section{Kapitalakkumulation og former for indkomst- politik}

Det er ganske vist nødvendigt at legitimere en sådan ydre begrænsning af arbejdslønnen overfor de, der bliver berørt heraf, idet det jo drejer sig om en begrænsning af arbejdskraftens reproduktionsgrundlag. Således begrundes lønbegrænsningen almindeligvis i propagandasammenhæng med, at lønmodtagerne stiller »umådeholdne « krav om en større del af nationalproduktet, og sådanne krav må ikke overdrives. Ifølge denne argumentation skal lønmodtagernes »retfærdige « andel af nettoproduktet bestemmes af stigningen i (arbejds-) produktiviteten, hvis kravene til virksomhedernes ydeevne ikke skal blive for store og dermed true arbejdspladserne. Arbejdsproduktiviteten betragtes altså her som indikator på nettoproduktets tilvækst, som er den størrelse, der skal fordeles. Hvis lønpolitikken orienteres mod produktivitetsudviklingen (hvis der forekommer permanent snigende inflation inddrager man i reglen også pengeværdiforrengelsestakten i beregningen af den tilladelige lønstigning) synes fordelingen af det voksende nettoprodukt at være konstant, uden at selve væksten bliver truet. På den anden side benytter også (venstre-keynesiansk orienterede) fagforeningsfolk udviklingen i arbejdsproduktiviteten som orienteringsstørrelse for løntilvæksten. Det sker med den begrundelse, at tilvæksten i den effektive eftersp $\varnothing$ rgsel dermed vil holde $\varnothing$ konomien i en dynamisk ligevægt.

I det følgende vil vi forsøge at udvikle sammenhængen mellem løn og kapitaltilvækst, for på grundlag heraf at kunne unders $\varnothing$ ge hvorledes indkomstpolitikkens mest almindelige former fungerer. I tilknytning hertil fremstilles de historiske former, som indkomstpolitikken antager i de forskellige vesteuropæiske lande. I sidste afsnit vil vi på grundlag af det foregående udfolde den historisk udviklede sammenhæng mellem kapitalakkumulation, indkomstpolitik og fagforeninger.

\subsection{Lønbegrænsningens indflydelse på merværdirate og akkumulation - teoretiske sammenhænge}

Selv om de følgende overvejelser sker på basis af den marxske værditeori, vil vi her benytte os af prisstørrelser, således som de fremtræder empirisk. Det sker for at gøre sammenhængen mellem de forskellige former for indkomstpolitik og kapitalakkumulationen tydeligere og for at kunne belyse lønnens stilling $\mathrm{i}$ forhold til profitten samt arbejdsproduktivitetens og inflationens indflydelse på profitraten, profitmassen og akkumulationen. Hvis der forekommer afvigelser (på grund af prisformen) fra værditeorien, vil denne begrænsning blive bemærket. Man kan altså ikke kunne argumentere mod den følgende fremstilling med udgangspunkt i den såkaldte værdi-pris-transformation. 
Ved udviklingen af de følgende kvantitative sammenhænge forudsættes det, at kapitalen er den samfundsmæssige udviklings motor. Ved undersøgelsen af den statslige lønbegrænsning vil vi således betragte den kapitalistiske produktion som det den er, nemlig produktion og kapitalisering af profit, og ikke som fremstilling af et produkt med henblik på konsumtion og efterfølgende fordeling blandt de forskellige klasser. Også lønarbejdernes situation og beskæftigelsesniveau bestemmes primært af den kapitalistiske produktion forstået som produktion og kapitalisering af profit. De følgende formaliseringer fors $\emptyset$ ger således at opstille den kapitalistiske produktions egentlige mål og se det i sammenhæng med lønbegrænsningen.

\section{(a) Profitproduktion}

I den marxske (og i den klassiske) teori optræder profitten som bruttoproduktionsværdiens overskud (hhv. surplusprodukt) over produktionselementernes værdi: profit $=$ samlet produktværdi $\div$ (kapitalerstatning + lønsum $)$. Til vort formål er det ikke nødvendigt med en nærmere behandling af arbejdskraftens værdibestemmelse. Idet kapitalerstatningen (c) er uden betydning for profittens hhv. lønnens andel af nyværdien $(=\mathrm{V}+\mathrm{P})$, dvs. for bestemmelsen af i hvilken grad kapitalen udbytter lønarbejdet

$$
\frac{\mathrm{P}}{\mathrm{V}}=\frac{\mathrm{Y}}{\mathrm{V}} \div 1
$$

kan man udtrykke den surplusværdi, som kapitalen tilegner sig til tidspunkt (t), i følgende formel:

(1) $\mathrm{P}(\mathrm{t})=\mathrm{Y}(\mathrm{t}) \div \mathrm{W}(\mathrm{t}) \mathrm{L}(\mathrm{t})$.

$\mathrm{W}(\mathrm{t}) \mathrm{L}(\mathrm{t})=\mathrm{V}$ og nyværdien $(=\mathrm{V}+\mathrm{P})=\mathrm{Y}(\mathrm{t})$.

Denne formel udtrykker, at nyværdiens (skabt af de produktive lønarbejdere) værdioverskud (merværdi) over lønnen (den betalte del af nyværdien resp. den del, som de umiddelbare producenter kan tilegne sig) - hvor dette værdioverskud tilegnes af kapitalen - udgør profittens kilde. Dermed har vi også antydet at profitten udspringer af vareproduktionen og ikke af varernes afhændelse. Hvis vi i denne formel yderligere inddrager det samfundsmæssige arbejdes produktivitet (som fra kapitalens standpunkt bidrager til øgning af profitten) samt prisændringer, kan profitten til tidspunkt (t) (hvor $\mathrm{t}>$ to) udtrykkes på følgende måde:

(2) $\mathrm{P}(\mathrm{t})=\mathrm{Y}\left(\mathrm{t}_{0}\right)(1+\mathrm{q})^{\left(\mathrm{t} \div \mathrm{t}_{0}\right)}+\mathrm{Y}\left(\mathrm{t}_{0}\right)(1+\mathrm{q})^{\left(\mathrm{t} \div \mathrm{t}_{0}\right)} \mathrm{p} \div \mathrm{W}(\mathrm{t}) \mathrm{L}(\mathrm{t})$.

Denne formel kan også skrives således:

$$
P(t)=Y\left(t_{0}\right)(1+q)^{\left(t \div t_{0}\right)}(1+p) \div W(t) L(t)
$$


For overskuelighedens skyld vil vi i det følgende betegne

$\mathrm{Y}\left(\mathrm{t}_{0}\right)(1+\mathrm{q})^{\left(\mathrm{t} \div \mathrm{t}_{0}\right)}$ som $\mathrm{Y}(\mathrm{t})$ og $\mathrm{Y}\left(\mathrm{t}_{0}\right)(1+\mathrm{q})^{\left(\mathrm{t} \div \mathrm{t}_{0}\right)}(1+\mathrm{p})$ som $\mathrm{Y}+(\mathrm{t})$.

I (2) og (3) betyder

$\mathrm{Y}$ nyværdien $(=\mathrm{V}+\mathrm{P})$ i løbende priser,

q nettoproduktets vækstrate, som er bestemt af intensiveringen af arbejdet, $\varnothing \mathrm{g}$ ningen af produktivkraften etc. (=»udviklingen i arbejdsproduktiviteten $\ll)^{16}$,

p koefficient, som udtrykker prisændringsraten efter ( $t)$, Wpengelønnen pr. arbejdsenhed og

$\mathrm{L}$ antal arbejdsenheder.

Den »relative inflation« (se Hoffmann 1962, s. 10) kommer altså til udtryk $\mathrm{i}\left(\mathrm{Y}\left(\mathrm{t}_{0}\right)(1+\mathrm{q})^{\left(\mathrm{t} \div \mathrm{t}_{0}\right)}\right)$, idet (ifølge den marxske opfattelse) $\mathrm{Y}$ (altså nyværdien) ikke vokser når arbejdets produktivkraft øges (hvorimod merværdiraten kan vokse); $\mathrm{Y}$ forbliver konstant - alt andet lige. Stigende arbejdsproduktivitet og prisstigninger, som er større end stigningen i pengelønnen, resulterer i profitstigninger, som realiseres af kapitalen. I den kapitalistiske produktion sker der ikke en quasi»automatisk « ændring af lønnen, når produktiviteten ændres ${ }^{17}$ (idet kapitalen resp. besidderne af produktionsmidlerne på forhånd tilegner sig nyværdien og værdioverskuddet over lønnen). I en given situation er fagforeningernes magtposition og de bedriftsnære og centrale klassekampe af betydning for pengelønnens størrelse. Først herigennem er arbejderne i stand til at skaffe sig en andel af stigningen i arbejdets produktivkraft. Derfor er $\mathrm{W}(\mathrm{t}) \mathrm{L}(\mathrm{t}) \mathrm{i}(2)$ heller ikke - som det ofte sker - koplet til produktivitetstilvæksten. (At de såkaldte fordelingskvoter

$$
\frac{\mathrm{P}}{\mathrm{Y}}(=\text { profitkvoten }) \text { og } \frac{\mathrm{W} \cdot \mathrm{L}}{\mathrm{Y}}(=1 \emptyset \text { nkvoten })
$$

alligevel ikke forbliver upåvirkede, når de koples til produktiviteten, vil vi senere behandle yderligere.)

Af formlen (3) kan man videre udlede merværdiraten, idet begge sider divideres med $\mathrm{W}(\mathrm{t}) \mathrm{L}(\mathrm{t})$ :

$$
\begin{aligned}
& \text { (4) } \frac{\mathrm{P}(\mathrm{t})}{\mathrm{W}(\mathrm{t}) \mathrm{L}(\mathrm{t})}=\frac{\mathrm{Y}\left(\mathrm{t}_{0}\right)(1+\mathrm{q})^{\left(\mathrm{t} \div \mathrm{t}_{0}\right)}(1+\mathrm{p})}{\mathrm{W}(\mathrm{t}) \mathrm{L}(\mathrm{t})} \div 1 \\
& =\quad \frac{\mathrm{Y}+(t)}{\mathrm{W}(\mathrm{t}) \mathrm{L}(\mathrm{t})} \quad \div 1 \text {. }
\end{aligned}
$$

16. Det i den borgerlige teori anvendte begreb »arbejdsproduktivitet« er ganske vist ikke identisk med det marxske begreb arbejdets produktivkraft. Det førstnævnte begreb omfatter voksende indkomst uden tillæg af kapital, intensivering af arbejdet, stigende kapacitetsudnyttelse, udvikling af produktionspotenserne (masseproduktion) og »tekniske fremskridt «.

17. Derfor er Nutis fors $\emptyset \mathrm{g}$ på at nærme sig de forskellige former for indkomstpolitik (»incomes policy «) ud fra lønsiden eller reallønnens mulige vækstrate forvirrende, fordi han vender den virkelige sammenhæng i den kapitalistiske produktion på hovedet (jvf. Nuti 1969, s. 434ff). 
Her må man ganske vist være opmærksom på, at $\mathrm{Y}+(\mathrm{t})$ også konsumeres af kapitalisterne i deres egenskab af konsumenter og af kapitalen i form af produktionsmidler; prisstigningerne kan altså kun optræde som profittilvækst for den samfundsmæssige totalkapital, hvis de medfører en virkelig omfordeling mellem klasserne.

Den ovenfor udviklede formel (2) viser altså, at den af kapitalen tilegnede profitmasse (her er der endnu ikke taget hensyn til profitmassens videre opdeling) er det samlede resultat af

1) udviklingen i arbejdets produktivkraft (q) - incl. arbejdets intensitet -,

2) prisniveauets udvikling (p) og

3) pengelønnens udvikling.

Man må i første omgang fastholde, at løn- og klassekampen ganske vist er bestemmende for pengelønnen, men ikke for reallønnen og heller ikke for merværdiraten (jvf. ligning (4)) hhv. fordelingskvoterne. Disse overvejelser er allerede indlysende af den grund, at den kapitalistiske produktion ved at $\varnothing$ ge arbejdets produktivkraft og intensitet ændrer fordelingskvoterne til fordel for profitkvoten, hvilket følger af, at produktivitetsudviklingen i første omgang kun berører profitindkomsterne. Derfor er fordelingskvoterne heller ikke bestemt af klassekampen; men klassekampen kan dog lidt efter lidt ændre dem (jvf. Kalecki 1971).

\section{(b) Profittens kapitalisering}

Den ovenfor udviklede profitmasse $\mathrm{P}(\mathrm{t})$ akkumuleres (dvs. kapitaliseres) ikke i sin helhed. Vi skal nu vise hvad der begrænser den akkumulerbare profit. Det drejer sig om

- kapitalisternes og de uproduktive mellemlags forbrug, som for størstedelens vedkommende betales ved hjælp af renteindtægter af penge- og realformuer. Dette forbrug sker på bekostning af den akkumulerbare profit $(=\mathrm{cP}(\mathrm{t}))$.

- skattebyrden, der lægges på profitten $(=S K p(t))$.

Således kan den akkumulerbare profit skrives på følgende måde:

(5) $\mathrm{a}(\mathrm{t}) \mathrm{P}(\mathrm{t})=\mathrm{P}(\mathrm{t}) \div(\mathrm{cP}(\mathrm{t})+\mathrm{Skp}(\mathrm{t}))$

Når den akkumulerbare del af profitten investeres som tillægskapital, deler den sig på flere lønarbejdere og mere konstant kapital: $\Delta \mathrm{v}+\Delta \mathrm{c}=\mathrm{a}(\mathrm{t}) \mathrm{P}(\mathrm{t})$. Heraf ses det, at lønarbejdernes beskæftigelse afhænger af kapitalens reproduktion. Den samfundsmæsige totalkapitals $(\mathrm{C}=\mathrm{c}+\mathrm{v})$ vækstrater bestemmes således af a) de faktorer, der bestemmer profitmassens vækst og b) af akkumulationsraten. Når profitraten for den produktive kapital er

$$
\mathrm{pi}=\frac{\mathrm{a}(\mathrm{t}) \mathrm{P}(\mathrm{t})}{\mathrm{C}(\mathrm{t})}
$$


vokser samfundets produktive kapital (vi ser her bort fra ændringen i den organiske sammensætning og dermed i profitraten) med raten pi:

(6) $\mathrm{C}(\mathrm{t})=\mathrm{C}\left(\mathrm{t}_{0}\right)(1+\mathrm{pi})^{\left(\mathrm{t} \div\left(\mathrm{t}_{0}\right)\right.}$.

Af (1), (5) og (6) udledes den samfundsmæssige totalkapitals profitrate

$$
\text { (7) } \frac{\mathrm{P}(\mathrm{t})}{\mathrm{C}(\mathrm{t})}=\frac{\mathrm{a}(\mathrm{t}) \mathrm{P}(\mathrm{t})+\mathrm{cP}(\mathrm{t})+\mathrm{SkP}(\mathrm{t})}{\mathrm{C}(\mathrm{t})}
$$

Heraf følger, at

$$
\frac{\mathrm{P}(\mathrm{t})}{\mathrm{C}(\mathrm{t})}>\frac{\mathrm{a}(\mathrm{t}) \mathrm{P}(\mathrm{t})}{\mathrm{C}(\mathrm{t})}
$$

(c) Indkomstpolitikkens virkninger på produktion og kapitalisering af profit (angående indkomstpolitikkens mulige former se Adam (1972) og Nuti (1969))

Tidligere fremstillede vi profitproduktionen som mål for den kapitalistiske produktion. Lønnen, som er lønarbejderindkomstens pengeform, er kun en værdi, der skal reproduceres, og ved en given nyværdi udgør den profittens nedre grænse. Nu skal vi relatere den ovenfor udviklede sammenhæng til de forskellige former for lønbegrænsning.

Første form er lønstop, prisstop eller løn- og prisstop. Denne form kan vi hurtigt analysere ved hjælp af ligning (2): Hvis kun lønnen begrænses $(\mathrm{W}(\mathrm{t}) \mathrm{L}(\mathrm{t})=$ konstant $)$, vokser profitten $\mathrm{P}(\mathrm{t})$ åbenbart med $\mathrm{Y}+(\mathrm{t})$. Hvis både lønninger og priser begrænses, vokser profitten $\mathrm{P}(\mathrm{t})$ med nettoproduktet $\mathrm{Y}(\mathrm{t})$; hvis det derimod kun er priserne, der begrænses, vokser profitmassen (under forudsætning af, at løntilvæksten ikke er større end stigningen i nettoproduktet $\mathrm{Y}(\mathrm{t})$ - jvf. vor undersøgelse af den tredie form for lønbegrænsning) med nettoproduktet $\mathrm{Y}(\mathrm{t})$, altså væsentligst med stigningen i arbejdets produktivkraft.

Den anden form for lønbegrænsning sigter på at lade lønnen stige i samme takt, som pengene falder i værdi, eller at binde lønnen til et prisindex. Dette medfører - som man kan se af (3)-, at merproduktet og dermed profitten vokser direkte med nettoproduktet, hvis vækstrate formindskes med faldet i pengenes værdi. Indkomstfordelingen ændrer sig løbende til ugunst for arbejderne:

$$
\frac{\mathrm{W}(\mathrm{t}) \mathrm{L}(\mathrm{t})}{\mathrm{Y}+(\mathrm{t})} \text { falder og } \frac{\mathrm{P}(\mathrm{t})}{\mathrm{Y}+(\mathrm{t})} \text { stiger. }
$$

Udbytningen af lønarbejderne vokser altså med stigningen i arbejdsproduktiviteten. 


$$
\text { Når } \frac{P(t)}{V(t)}=\frac{Y+(t)}{V(t)} \div 1 \text { og } \frac{d Y}{d t Y}>\frac{d V}{d t V}
$$

betyder det, at udbytningen af arbejderne stiger. Dermed vokser også den produktive kapitals profitrate $\frac{\mathrm{a}(\mathrm{t}) \mathrm{P}(\mathrm{t})}{\mathrm{C}(\mathrm{t})}$; akkumulationen fremskyndes.

Tredie form begrænser løntilvæksten, således at den følger tilvæksten i arbejdsproduktivitet. Hvis »produktivitetsorienterede lønpolitik « bliver almindelig, stiger pengelønnen med raten q:

$\mathrm{W}(\mathrm{t})=\mathrm{W}\left(\mathrm{t}_{0}\right)(1+\mathrm{q})^{\left(\mathrm{t}_{0}\right)}$

Raterne q og p påvirker imidlertid profitstigningen:

$\left.\mathrm{P}(\mathrm{t})=\mathrm{Y}\left(\mathrm{t}_{0}\right)(1+\mathrm{q})\right)^{\left(\mathrm{t} \div \mathrm{t}_{0}\right)}(1+\mathrm{p}) \div \mathrm{w}\left(\mathrm{t}_{0}\right)(1+\mathrm{q}){ }^{\left(\mathrm{t} \div \mathrm{t}_{0}\right)} \mathrm{L}(\mathrm{t})$.

Anvendelsen af denne simple form for produktivitetsorienteret lønpolitik betyder altså, at den profitmasse, som produceres af arbejderne og tilegnes af kapitalen, vokser endnu hurtigere end pengelønnen. Det viser sig således at være en illusion at tro, at abejderne gennem en produktivitetsorienteret lønpolitik fuldt ud kan få udbytte af produktivitetstilvæksten i form af stigende realløn. Tværtimod stiger profitten og den kapitaliserede merværdi ligeså hurtigt som lønnen eller endog hurtigere, når priserne stiger med raten p. På denne måde ændrer fordelingskvoterne for nettoproduktet sig til ugunst for arbejderne, og udbytningsraten stiger; ligeledes stiger profitraten

$\mathrm{pi}=\frac{\mathrm{a}(\mathrm{t}) \mathrm{P}(\mathrm{t})}{\mathrm{C}(\mathrm{t})}$; inflationsraten fremmer akkumulationen.

I den fjerde form for lønbegrænsning bindes løntilvæksten til prisstigninger og produktivitetstilvækst. Herigennem sker der i bedste fald en fastfrysning af fordelingsforholdene og udbytningraten. At der kun i bedste fald sker en sådan fastfrysning, beror på følgende sammenhænge (som i øvrigt også gælder for de andre former, vi her diskuterer):

Når man måler økonomiens produktivitet som helhed (som de enkelte produktionsgrenes vægtede, aggregerede produktivitet) får man ikke et udtryk for ændringen i udbytningen eller udbytningsgraden.

Det skyldes, at de uproduktive sektorer som f.eks. dele af tjenesteydelsessektoren trækker raten for produktivitetsudviklingen nedad, hvilket betyder en mindre samlet løntilvækst. Endvidere stammer indtægterne fra uproduktivt arbejde, som hverken skaber værdi eller merværdi, fra en allerede produceret nyværdi; alligevel betragtes de i »totalberegningen « som arbejdsindkomster (tjenesteydelser, statsansatte etc. - jvf. tillæg II). Det uproduktive arbejdes ekspansion som del af totalarbejdskraften - hvilket er et nødvendigt ledsagefænomen til udviklingen i arbejdets produktivkraft og til kapitalismens $\varnothing$ gning af merproduktet - frembringer på den ene side ikke nogen yderligere nyværdi; på den anden side betyder denne udvikling, at lønkvoten stiger. Når altså $\mathrm{Y}+(\mathrm{t})=(\mathrm{y}+1)$, men $\mathrm{W}(\mathrm{t}) \mathrm{L}(\mathrm{t})<\mathrm{W}(\mathrm{t}+1) \mathrm{L}(\mathrm{t}+1)$, vil lønkvoten være stigende: 


$$
\frac{\mathrm{W}(\mathrm{t}+1) \mathrm{L}(\mathrm{t}+1)}{\mathrm{Y}+(\mathrm{t}+1)}>\frac{\mathrm{W}(\mathrm{t}) \mathrm{L}(\mathrm{t})}{\mathrm{Y}+(\mathrm{t})}(\text { idet } \mathrm{Y}+(\mathrm{t})=\mathrm{Y}+(\mathrm{t}+1)),
$$

og udbytningsgraden synes at falde, fordi lønsummen er steget.

Den tese, at lønandelen på langt sigt forbliver konstant eller endog stiger, har man søgt at bevise gennem empiriske unders $\varnothing$ gelser. Den er imidlertid yderst problematisk på grund af den manglende skelnen mellem produktivt og uproduktivt arbejde - en skelnen, som også er forsvundet ud af de videnskabelige borgerlige diskussioner siden slutningen af forrige århundrede.

Idet de uproduktive arbejdere må betales af den almene profit eller gennem skatter på denne profit (SkP) - såvel som på lønnen-, er resultatet af det uproduktive arbejdes ekspansion som del af totalbeskæftigelsen muligvis en faldende akkumulationsrate $(\mathrm{a}(\mathrm{t}) \mathrm{P}(\mathrm{t})$ ). (Indenfor den kapitalistiske produktionsmåde er det klart, at kapitalen vil forsøge at holde sig skadesløs gennem de produktive arbejderes lønninger.)

Heraf følger, at lønkvoten kan forblive konstant eller endog stige, samtidig med at der sker en stigende udbytning af de produktive lønarbejdere. Den produktivitetsorienterede lønpolitik ændrer intet ved dette forhold; hvordan kan man ellers forklare modsigelsen mellem på den ene side de »konstante fordelingsforhold « og på den anden side den samtidige akkumulation af rigdom hos den besiddende klasse, mens lønarbejderklassen blot reproduceres, hvis ikke ved en stigende udbytning af de produktive lønarbejdere som følge af udviklingen $\mathrm{i}$ arbejdets produktivkraft.

Den femte form for lønbegrænsning vender den hidtidige sammenhæng om. Profitten betragtes her ikke længere som et overskud, der skal øges; omvendt betragtes lønnen som en residualstørrelse. Denne form stiller krav til lønarbejderne om gennem lave lønninger og dermed lavt konsumtionsniveau at fremme akkumulationen. Man går her ud fra et bestemt profit- og akkumulationsbehov, som skal dækkes, for at opnå bestemte givne eller planlagte vækstrater. (I en modificeret form inddrager man også statens financielle behov ved udvidet produktion af materielle produktionsbetingelser, som følger af kapitalens akkumulationsudvikling, i en sådan lønberegning (jvf. Gahlen 1973)). Lønnen, de umiddelbare producenters reproduktionsniveau, forvandles således til en residualstørrelse, som bliver til overs, når man har fratrukket den profitmasse, der er nødvendig til financiering af »indkomsttilvæksten« og nettoproduktets akkumulation. Følgelig gælder her $\mathrm{W}(\mathrm{t})=\mathrm{Y}(\mathrm{t}) \div \mathrm{P}(\mathrm{t})$. (For overskuelighedens skyld inddrager vi ikke prisstigningerne i vore videre overvejelser.)

Idet kapitalens vækstrate (som er bestemt af den produktive kapitals profitrate pi) - her betragtet over en periode - er pi $=\frac{\mathrm{C}(\mathrm{t})}{\mathrm{C}\left(\mathrm{t}_{0}\right)} \div 1$ (se (6)) og samtidig lig med profitraten $\mathrm{pi}=\frac{\mathrm{a}\left(\mathrm{t}_{0}\right) \mathrm{P}\left(\mathrm{t}_{0}\right)}{\mathrm{C}\left(\mathrm{t}_{0}\right)}$, får vi ved at sætte de to udtryk lig med hinanden og omforme dem, at den profitmasse, der er nødvendig for kapitalens vækst, nemlig $\mathrm{P}\left({ }_{0}\right)$, bliver 


$$
\text { (8) } \quad \mathrm{P}\left(\mathrm{t}_{0}\right)=\frac{\mathrm{C}(\mathrm{t}) \div \mathrm{C}\left(\mathrm{t}_{0}\right)}{\mathrm{a}\left(\mathrm{t}_{0}\right)}
$$

$\left(\mathrm{C}(\mathrm{t}) \div \mathrm{C}\left(\mathrm{t}_{0}\right)\right)$ svarer så nogenlunde til investering $\mathrm{I}$, men indeholder også et tilskud af variabel kapital. Hvis indkomsten vokser med q

$$
\left(q=\frac{Y(t)}{Y\left(t_{0}\right)} \div 1\right)
$$

og hvis den nødvendige kapitalbeholdning pr. enhed af Y er

$\mathrm{v}=\frac{\mathrm{C}\left(\mathrm{t}_{0}\right)}{\mathrm{Y}\left(\mathrm{t}_{0}\right)}$ (hos Harrod-Domar: $\frac{\mathrm{K}}{\mathrm{Y}}=\mathrm{v}=$ kapitalkoefficienten),

betyder det, at

(9) $\mathrm{q} Y\left(\mathrm{t}_{0}\right) \mathrm{v}=\mathrm{C}(\mathrm{t}) \div \mathrm{C}\left(\mathrm{t}_{0}\right)=$ den nødvendige akkumulationsmasse.

$\left(\mathrm{qY}\left(\mathrm{t}_{0}\right) \mathrm{v}\right)$ er altså et udtryk for det »investeringsniveau, der er nødvendigt«, for at sikre at indkomsterne vokser med raten

$$
\mathrm{q}=\frac{\mathrm{Y}(\mathrm{t}) \div \mathrm{Y}\left(\mathrm{t}_{0}\right)}{\mathrm{Y}\left(\mathrm{t}_{0}\right)}
$$

Af (8) og (9) får vi lønnen som residualstørrelse

$$
\begin{aligned}
& \text { (10) } \mathrm{W}(\mathrm{t})=\mathrm{Y}(\mathrm{t}) \div \frac{\mathrm{C}(\mathrm{t}) \div \mathrm{C}\left(\mathrm{t}_{0}\right)}{\mathrm{a}} \\
& =\mathrm{Y}(\mathrm{t}) \div \frac{\mathrm{qY}\left(\mathrm{t}_{0}\right) \mathrm{v}}{\mathrm{a}}
\end{aligned}
$$

Her betragtes kapitalismen som noget, den ifølge sin natur ikke kan være: produktion med henblik på forbrug og ovenikøbet voksende forbrug. Målet er tværtimod kapitalens reproduktion og forøgelse. På den ene side indebærer enhver standsning og enhver formindskelse kapitalinvesteringerne som følge af faldende profitter, at indkomsterne bliver mindre samt at lønarbejdere fyres. På den anden side medfører de statsindgreb, som foretages med henblik på opretholdelse af et nødvendigt profitniveau og en bestemt investeringskvote, at der akkumuleres rigdom hos de, der ejer produktionsmidlerne; herigennem sikres endvidere lønarbejdernes blotte reproduktion. I opgangsfaser bliver denne form for indkomstpolitik derfor også populær blandt kapitalister og i statens økonomiske politik. Man kræver et lavt lønniveau og »forbrugstilbageholdenhed « for at sikre den profit, som er nødvendig for kapitalakkumulationen (som det f.eks. skete i Vesttyskland i 50'erne). Det er endvidere ikke muligt gennem formue- og mfordelingsplaner at korrigere det forhold, at der ophobes rigdom og 
samfundsmæssig magt hos de besiddende som følge af kapitaldannelsesprocessen; thi de besiddende $\varnothing$ nsker ikke at pille ved de produktionsforhold, som udgør grundlaget for deres $\varnothing$ konomiske og politiske magt.

Uanset hvilken form for lønbegrænsning staten anvender (og har anvendt), vil virkningerne for profitproduktionen og kapitalakkumulationen være følgende:

- stigende profitmasse, stigende eller - i bedste fald - konstant udbytningsgrad og stigende profitrate (eller ophævelse af profitratens fald) samt fornyet akkumulation,

- fald i reallønnens andel af nettoproduktet og et delvist fald i lønarbejderklassens realløn og

- i forbindelse hermed styrkelse af den besiddende klasses samfundsmæssige og politiske magt og svækkelse af lønarbejderklassen og dens organisationer.

\subsection{Den statslige lønbegrænsnings historiske gennemsættelsesformer} (generelt om dette: United Nations (1967); IFS-Zwischenbericht (1969); Kidron (1971); Ahnefeld (1972)).

De former for indkomstpolitik, som her har været gjort til genstand for en teoretisk diskussion, er blevet anvendt af de enkelte regeringer i forskelligt omfang og med tidsmæssige forskydninger. Alligevel kan vi generelt - med baggrund i den tidligere fremstillede historiske skitse - udskille fire faser i den indkomstpolitiske udvikling i Vesteuropa.

Første fase falder tidsmæssigt sammen med kapitalakkumulationens første fase i Vesteuropa, som vi tidligere har beskrevet; i denne fase udgjorde indkomstpolitikken et forsøg på, gennem en langsigtet indirekte påvirkning, at bringe lønudviklingen i overensstemmelse med kapitalakkumulationens behov for derigennem at fremme opsvinget $\mathrm{i}$ akkumulationsbevægelsen (femte form for lønbegrænsning). Som følge af, at der i mange lande forekom en relativ høj underbeskæftigelse, var det ikke nødvendigt at anvende tvangsmidler for at gennemføre en sådan politik. I nogle lande, som f.eks. Holland, var en sådan lønpolitik bestanddel af en statslig udviklingsplanlægning, samtidig med at den blev gennemført uafhængigt af overenskomstforhandlingerne (i Holland skete det med udtrykkelig tilslutning fra fagforeningerne; overhovedet undlod mange nationale fagforeningsorganisationer i denne periode at føre aktiv lønpolitik for derigennem at bidrage til den nødvendige genopbygning).

Anden fase i den indkomstpolitiske udvikling skyldes en stigende lønkvote samt opståede konflikter i kapitalens reproduktions- og vækstproces. I mange lande kunne sådanne konflikter for en tid formidles gennem en fremskyndet penge- og finanspolitik (hvilket fremkaldte inflatoriske processer). Forud var gået en stigning i lønkvoten, en opløsning af korporative forestillinger blandt arbejderne under højkonjunkturen og en styrkelse af fagforeningernes forhandlingsposition. 
Denne nye fase falder tidsmæssigt sammen med starten på kapitalakkumulationens anden fase (begyndelsen eller midten af 60'erne). I denne periode blev det relevant at foretage lønbegrænsninger i samtlige vestlige lande. Det viste sig ved at forestillinger her om dukkede op i den teoretiske ( $\varnothing$ konomiske) diskussion, eller ved at sådanne forestillinger allerede nu blev omsat i praksis. Hvornår de statslige lønbegrænsninger blev iværksat, og hvor dybt de gik, var hovedsagelig bestemt af hvorvidt de enkelte lande, gennem deres særlige stilling på verdensmarkedet, kunne »externalisere « de immanente konflikter i den nationale kapitals reproduktionsproces. Dette viste sig f.eks. positivt i Vesttyskland og negativt i England. En undersøgelse fra OECD, som udkom i 1961 (Fellner m.fl. 1961), hvori man anbefalede indkomstpolitik som middel mod inflatoriske processer i medlemslandene, var en impuls til iværksættelse af lønbegrænsningsfors $\varnothing$ g. De foranstaltninger, man griber til (tidsmæssigt falder de sammen med skærpede arbejdskampe i Italien, Frankrig og Vesttyskland), er i det væsentlige oprettelse af løn- og priskontrolkommisioner (eller hvis sådanne allerede eksisterede, som f.eks. i Holland og Østrig, udvidede man deres beføjelser.) Disse kommisioner har til opgave, gennem udarbejdelse af grænser for løn- og prisstigninger, at udøve pression ved lønforhandlingerne (som i nogle lande i stadig større grad centraliseres statsligt). I lande, som endnu ikke ønsker (eller er tvunget til) at gå så langt, hvilket gælder f.eks. Vesttyskland, hvor man først i 1963 førte en »intern« diskussion om at lægge loft over lønningerne (jvf. Schlecht 1968, s. 12), skabte man i det mindste forudsætningerne for videregående statslig indflydelse på arbejdslønnen. Det skete ved at intensivere den statslige eller statsstøttede kommisionsvirksomhed samt udviklingen af planlægningsansatser (oprettelse af et økonomisk råd i Vesttyskland, planlægningsdiskussioner i Italien, jvf. Monigliano i CGIL/CISL 1973, s. 145ff). Man angav også retningslinier for lønudviklingen, idet man gennem forudgående forhandlinger med arbejderne i statslige virksomheder eller i offentlig tjeneste fastsatte lønstigninger, der skulle tjene som retningslinier for lønudviklingen i den private sektor. Det er karakteristisk, at man lægger loft over lønningerne ved at binde lønnen til produktivitetsudviklingen eller til et prisindex (form II-IV); den førstnævnte fremgangselsdæmpende fordi man derigennem mente at kunne dæmme op for de inflatoriske processer (neutral i forhold til omkostningsniveauet og efterspørgselsdæmpende) og den sidstnævnte fremgangsmåde, fordi man ellers måtte regne med modstand fra fagforeningerne, som var blevet styrkede i denne fase.

En tredie indkomstpolitisk fase opstår i visse lande (her må man især nævne England) som statens svar på de manglende resultater af den statslige penge- og finanspolitik og de fejlslagne forsøg på at føre lønpolitik. Fra midten til slutningen af 60'erne viser grænserne for den statslige finanspolitik sig i forskellige lande - hvilket vi allerede har beskrevet. Det sker ved, at der optræder stagnationstendenser samtidig med prisstigninger; statsapparatet svarer igen med drastiske midler: pris- og lønstop (første form). En sådan politik er 
især blevet benyttet i USA. I Vesteuropa er det kun England, der praktiserer den i sin drastiske form; i andre lande forbindes den med lønkontrol eller en indexbinding af lønningerne til produktivitetsudviklingen (tredie form). I Frankrig indgår løn- og prisloft som en del af 1966-70-planen; i Vesttyskland forsøger man i form af »Konzertierte Aktion« en løs løn- og prisplanlægning. Når både de skærpede (som i England) og de løsere (som i Vesttyskland) forsøg på lønbegrænsning slår fejl skyldes det væsentligst modstand fra arbejderne og deres organisationer. Foranstaltningerne giver i sig selv anledning til en skærpelse af arbejdernes og fagforeningernes forsvarskampe (på hhv. bedriftsniveau og centralt niveau). Endvidere skal den statslige politik ophæve de lønforhøjelser, der opnås gennem konflikterne. I disse kampe har presset fra fagforeningsbasis, som i en vis udstrækning kan få opfyldt omfattende lønkrav gennem bedriftsnære kampe mod enkeltkapitaler, en særlig vigtig funktion. Fagforeningsledere, som til at begynde med er »samarbejdsvillige«, tvinges til at afvise de statslige lønbegrænsninger. (Dette gælder især for de engelske fagforeninger efter det første løn- og prisstop 1966/67.)

Disse konflikter indleder en fjerde indkomstpolitisk fase (ca. 1970). »Det mindstemål af samarbejdsvilje fra fagforeningernes side, som ville være nødvendigt for iværksættelsen af lønpolitiske foranstaltninger, var ofte ikke til stede. På den anden side var man ikke særlig tilbøjelig til, at benytte sig af en streng lønkontrol « (Ahnefeld 1972, s. 22). I denne fase søgte man at opnå to mål: For det første vil man gennem påvirkning af prisniveauet udøve indirekte pres på lønforhandlingerne (partielt prisstop for forbrugsvarer i Italien og Frankrig); for det andet søger man at begrænse det spillerum, som fagforeningerne og især deres bedriftsmæssige organisationer har. Dette sker gennem lovgivningsmæssige begrænsninger af fagforeningernes autonomi ved overenskomstforhandlingerne, gennem indgreb på arbejdsmarkedet og centralisering af lønforhandlingerne. Endvidere hæmmer man gennem lovgivning arbejdernes pres på deres organisationer (jvf. hvad der er gjort i England - Industrial Relation Act - eller i Holland og Sverige; i Italien fors øgte man gennem lovgivningen at beskære bedriftsrådenes beføjelser). Samtidig forsøger man at opbygge decentrale (regionale eller bedriftsnære) kontrolinstanser, med det formål at inddæmme »vildskuddene« blandt de bedriftsnære lønaftaler (jvf. for England Blackaby 1972, s. 4).

Overfor stadig snævrere profitmarginaler og statens stigende indhug i kapitalens akkumulationsfond opstår der et fornyet krav om loft over lønningerne. Dette krav forudsætter, at kapitalens akkumulationsfond og statens konsumtionsfond er uafhængige variable, mens lønnen optræder som en residualstørrelse (vi har her at gøre med den femte form for lønbegrænsning udvidet med de statslige fordringer. Denne form anbefalede Gahlen (1973, s. 524-534) fagforeningerne i Vesttyskland, hvor man stod overfor nødvendige reformer, der skulle finansieres). En sådan politik havner i et dilemma. Det sker på to punkter: Bortset fra de tidligere udviklede modsigelser i den statslige 
$\emptyset$ konomiske politik skærpes kapitalernes værdiøgningsvanskeligheder på grund af det nødvendigvis stigende skattemæssige fradrag fra akkumulationsfonden, mens sådanne statslige investeringer på langt sigt er en forudsætning for en videre reproduktion. Endvidere sker fors $\varnothing$ get på at finansiere en del af disse omkostninger gennem et skattemæssigt fradrag fra lønnen samt det videregående fors $\emptyset \mathrm{g}$ på at begrænse reallønnen og indskrænke fagforeningernes rettigheder (som delvis hører sammen med indrømmelser i spørgsmålet om medbestemmelse og formuedannelse) i en periode, hvor fagforeningsledelsen på grund af pres fra medlemmerne er tvunget til mere resolut at forsvare medlemmernes interesser overfor kapitalens og statens pres. Ovenfor har vi skitseret tre almene skranker for statens indflydelse på reproduktionsprocessen. Her støder statens politik på en fjerde almen skranke: arbejderklassens modstand!

\section{Statslig lønbegrænsning, klassekampe og fagforeninger i Vesteuropa}

Arbejdernes og fagforeningernes modstand mod den statslige lønbegrænsning (og denne politiks deraf følgende fejlslag - i det mindste hvad angår dens mere drastiske former) er i sin voksende styrke selv et alment resultat af kapitalens udvikling i Vesteuropa. Selv om bestemte klassekamptraditioners forskellige nationale særpræg (f.eks. i Italien, Frankrig og England; negativt i Vesttyskland) har betydelig indflydelse på kampens form og heftighed, og selv om eksistensen af kommunistiske partier i Italien og Frankrig er en vigtig forudsætning for arbejdernes partielle succes i disse lande, så skyldes den næsten samtidige genopblussen af klassekampbevægelser og de almene mål, der formuleres i disse kampe, ikke blot særlige nationale forhold.

Det er således på de områder, som vi har nævnt som almene, at modsætningen mellem lønarbejde og kapital atter fremtræder: Begrænsning af lønbevægelsen gennem statsindgreb, intensivering af arbejdet og overakkumulationstendenser samt den deraf følgende frisættelse af arbejdskraft og underbeskæftigelse. Dette har også været kampens almene udgangspunkter (jvf. Albers m.fl. 1971): - konflikter om reallønnens højde mellem lønarbejde og kapital resp. stat,

- forsvarskampe mod arbejdets intensivering,

- kampe mod nedlæggelser, afskedigelser og arbejdsløshed.

Som lønarbejdernes organisationer inddrages fagforeningerne dobbelt i denne proces: Som medlemsorganisationer må de effektivt forsvare medlemmernes interesser overfor kapital og stat, dvs. at de er under »legitimeringstvang « (jvf. Bergmann 1973). Et sådant forsvar bliver yderligere påkrævet, fordi kapitalen 
i den vesteuropæiske akkumulationsbevægelses anden fase ikke længere har samme spillerum for indrømmelser, som den havde under den blomstrende kapitalakkumulation. Tidligere under højkonjunkturen resulterede fagforeningernes lønpolitik næsten automatisk i lønforhøjelser, som blev taget fra virksomhedernes stigende indtjening. Kapitalen er imidlertid ikke længere i samme grad parat til at gøre indrømmelser. Derfor er fagforeningerne som organisationer blevet langt stærkere involveret i konflikterne. (Således er den centralisering af lønforhandlingerne, som er blevet gennemtvunget i visse vesteuropæiske lande med henblik på bedre kontrol med lønudviklingen, et tveægget sværd for staten, idet modsætningen mellem lønarbejde og kapital nu fremtræder på nationalt plan - som det f.eks. viste sig ved havnearbejderstrejken i England hvor der indenfor arbejderbevægelsen blev frigjort politiske potenser).

Et effektivt forsvar for lønarbejdernes interesser gennem fagforeningerne bliver på den anden side yderligere påkrævet, fordi kapitalen fors $\emptyset$ ger at $\emptyset$ ge det akkumulerbare merprodukt gennem intensivering af arbejdet, hvilket fører til øget nedslidning af arbejdskraften (jvf. for Vesttyskland Funke m.fl. 1974; i Italien er indførelsen af en ny arbejdsorganisation og dermed en intensivering af arbejdet i perioden 1964 til 1970 det væsentligste middel til øgning af arbejdets produktivkraft med henblik på at sikre øget profitproduktion). Selv om arbejderne ikke - som i Italien - kæmper mod de forværrede arbejdsbetingelser og den øgede nedslidning af arbejdskraften, så kræver de dog under lønforhandlingerne dækning for de stigende reproduktionsomkostninger for arbejdskraften. Oplevelsen af $\emptyset$ get nedslidning af arbejdskraften transformeres over i krav om højere (real-)løn, hvilket er udtryk for den illusion, at der under kapitalismen eksisterer en løn-præstationsækvivalent. I den periode, som vi her beskæftiger os med, opstår der en konflikt mellem en sådan transformation og statens fors $\emptyset \mathrm{g}$ på at begrænse lønnen. Den statslige lønpolitik forsøger (i den beskrevne fjerde fase) at binde fagforeningernes lønpolitik til kapitalens akkumulationsbehov (som er særlig store i stagnationsfasen), til nødvendigheden af at staten sætter sig på en stadig større del af nettoproduktet samt endelig til de konjunkturelle prisstabiliseringsforanstaltninger (vi har ikke behandlet de sidstnævnte foranstaltninger, fordi de kun forholder sig kortsigtet til den industrielle cyklus). Desuden forsøges det fra statens side at bryde fagforeningernes magt gennem en disciplinering af disse (ved hjælp af indgreb på arbejdsmarkedet og ved centralisering af fagforeningerne og lønforhandlingerne); i den udstrækning fagforeningerne er samarbejdsvillige skal de forpligtes overfor den statslige stabiliseringspolitik (på denne måde forsøger den socialliberale regering i Vesttyskland at udnytte de stadig stærkere bånd mellem SPD og fagforeningerne). Fagforeningernes politik er således placeret mellem arbejdernes berettigede reproduktionsbehov og kapitalens akkumulationsbehov, som delvis formidles gennem staten. Disse to poler kan ikke længere forenes, som det var tilfældet i perioden med blomstrende kapitalakkumulation. 
Resultatet må i sidste instans blive, at selv fagforeninger, som i begyndelsen var samarbejdsvillige ændrer selvforståelse og politik. Dette har vist sig i England, Frankrig og Italien, og samme udvikling kan anes i Vesttyskland.

Fagforeningerne forventer, at staten vil sammenkæde lønplanlægningen med langsigtede udviklingsplaner til sikring af fuld beskæftigelse, vækst, en retfærdig indkomstfordeling og stigende levestandard for de laveste lag (dette synes faktisk at være muligt når socialdemokraktiske partier er ved magten som $\mathrm{i}$ England og i de nordiske lande ${ }^{18}$ ). Dette er ikke den eneste grund til, at fagforeningerne $\emptyset$ nsker et indkomstpolitisk samarbejde med staten. Således taler det også for et sådant samarbejde, at fagforeningerne derigennem tilsyneladende får mulighed for at $\varnothing v e$ indflydelse på den $\varnothing$ konomiske politik, hvilket betyder, at de bedre vil kunne forsvare lønarbejdernes interesser. Imidlertid er denne indflydelses spillerum begrænset, og den afhænger af den historiske udvikling, nærmere bestemt af udviklingen i kapitalens akkumulationsbehov. Hvis fagforeningerne under de ovenfor skitserede forhold går ind på kapitalens og statens krav, kan de ikke længere effektivt forsvare deres medlemmers interesser, og de vil derfor nødvendigvis komme i et modsætningsforhold til disse; resultatet bliver, at der opstår interne konflikter i fagforeningerne, således som det i øjeblikket kan iagttages i Vesttyskland. Sådanne konflikter bliver farlige for en »samarbejdsvillig « fagforeningsledelse, hvis de, der fremfører den interne fagforeningskritik, forholder sig til arbejdernes mest påtrængende problemer, dvs. at de i deres krav orienterer sig mod arbejdskraftens nødvendige reproduktionsniveau. Herigennem kan de nemlig potentielt opnå en basis i fagforeningsorganisationen.

En alternativ fagforeningspolitik må være baseret på modstand mod statsindgrebene og på formuleringen af en autonom klassepolitik, orienteret mod arbejdernes reproduktionsbehov. En sådan politik kan ganske vist ikke blot kræves som alternativ; den er - som eksemplerne Italien, Frankrig og England viser (jvf. Albers m.fl. 1971) - selv et resultat af lønog klassekampe ${ }^{19}$. Den kommer i første omgang i modsætning til staten;

18. Dette er tydeligt i en protokol fra TUC (TUC 1967, s. 8). Også i præamblen til DGB's program (1963) gives der udtryk for sådanne forestillinger. At det indenfor visse grænser er muligt for staten således at vende sine planlægningspolitiske intentioner på hovedet, når den tvinges dertil gennem klassekampen, viser de italienske fagforeningers partielle resultater på dette område.

19. Deri ligger også den begrænsede udsagnskraft i samarbejds- hhv. konfliktorienterede modeller for fagforeningspolitik, således som de er blevet formuleret af f.eks. Müller-Jentsch (1973). Bortset fra, at det efter vort skøn er yderst problematisk at formulere en almen »teori« for fagforeningerne i »senkapitalismen«, fordi lønarbejderorganisationernes situation og politik ikke kan adskilles fra klassekampens udvikling (jvf. Redaktionskollektiv Gewerkschaften 1972, s. 87f), er fremgangsmåden i de nævnte fors øg den, at de stiller forskellige nye momenter i den samfundsmæssige udvikling op ved siden af hinanden, uden at formidlingssammenhængen mellem fagforeningspolitik og kapitalreproduktion bliver klar. Med dette udgangspunkt i »senkapitalisme-teoremet « videreudvikler man ikke længere de immanente konflikter i kapitalreproduktion. Problematikken reduceres i disse ansatser til et legitimeringsproblem (jvf. Bergmann 1973) indenfor fagforeningsorganisationen. 
dens sande skranke er imidlertid kapitalbevægelsen, hvis den ikke samtidig er udgangspunkt for en politisk massebevægelse til overvindelse af de kapitalistiske produktionsforhold, eller hvis den i det mindste ikke bliver bestemt af en sådan. Hvis dette ikke er tilfældet kan en sådan politik kun lykkes, når arbejdernes $\varnothing$ konomiske magt sættes af selve kapitalbevægelsen (f.eks. i opgangsperioder, hvor kapitalens efterspørgsel efter arbejdskraft $\emptyset$ ges). Enhver kriseagtig udvikling, som medfører, at arbejdskraft lægges brak, at virksomheder lukker etc. og/eller fremmer konkurrencen indenfor arbejderklassen, vil således gøre en sådan autonom klassepolitik illusorisk.

I en periode, hvor såvel den statslige penge- og finanspolitik som de statslige fors $\varnothing \mathrm{g}$ på lønbegrænsning støder på de ovenfor nævnte skranker, som kun - hvis den fulde beskæftigelse skal bibeholdes - kan overvindes gennem drastiske foranstaltninger (af planøkonomisk eller endog terroristisk karakter), er det således ikke tilfældigt, at $\varnothing$ konomer og politikere atter anbefaler en »naturlig arbejdsløshedsrate « (»natural rate of unemployment «, Friedmann og Phelps citeret efter Cassel 1972) som eneste udvej af dette dilemma. Dette er også udtryk for en tilbagevenden til neoklassikerne, her monetaristisk udtrykt: tilbage til den 'klassiske' kapitalistiske krisecyklus, hvor løntrykket skal ud$\emptyset$ ves af den industrielle reservearmé. Dette er også den rationelle kerne i den monetarisme i borgerlig teori og politik, som blev populær fra begyndelsen af 1970'erne. 


\section{TILLAEG I}

Lønkvoten i Vesttyskland, Frankrig og Italien (efter Kindleberger 1967, s. 24ff):

\begin{tabular}{lccc} 
Tid & Vesttyskland & Frankrig & Italien \\
\hline 1950 & 58,6 & 55,1 & 50,8 \\
\hline 1951 & 58,7 & 56,1 & 50,1 \\
1952 & 57,4 & 57,3 & 52,7 \\
1953 & 58,7 & 57,5 & 52,8 \\
1954 & 59,4 & 58,9 & 54,3 \\
1955 & 59,5 & 58,2 & 54,4 \\
\hline 1956 & 59,5 & 58,3 & 55,9 \\
1957 & 59,7 & 58,6 & 55,9 \\
1958 & 60,5 & 58,3 & 56,4 \\
1959 & 60,2 & 59,5 & 54,8 \\
1960 & 60,6 & 58,3 & 55,1 \\
\hline 1961 & 60,8 & 60,5 & 55,3 \\
1962 & 62,5 & 60,6 & 57,2 \\
1963 & 63,9 & 62,4 & $(62,5)^{*}$ \\
1964 & 64,8 & & $(63,8)^{*}$ \\
\hline
\end{tabular}

(Arbejdsindkomsternes andel af nettonationalproduktet; ()$^{*}=$ anden beregning!)

\section{TILLEG II}

Forhøjelse af lønkvoten på grund af de uproduktive lфnarbejdere

Vi har i teksten begrundet udviklingen af uproduktive (altså ikkemerværdisættende) sektorer med stigningen i arbejdets produktivkraft og dermed i merværdiraten for de produktive (merværdisættende) arbejdere. Denne virkelige sammenhæng vil vi i det følgende af pragmatiske grunde (for lettere at kunne håndtere den tilgængelige statistik) vende på hovedet, idet vi går ud fra udviklingen i lønkvoten og sammenligner denne med udviklingen i de uproduktive sektorer. Her skal vi gøre opmærksom på følgende begrænsning: De produktionssfærer, som i statistikken optræder som uproduktive sektorer (handel, transport, tjenesteydelser) er ikke ubetinget uproduktive i den marxske forstand. I disse sektorer beskæftiges der nemlig også direkte eller indirekte produktive lønarbejdere.

Lønkvoten skal her - forkortet - sammensættes på følgende måde

$$
\frac{W(t) L(t)}{Y(t)}=\frac{a(t)+b(t)+c(t)) W(t) L(t)}{Y(t)}
$$


Y(t) betragtes som funktion af de produktive lønarbejdere, således at $\mathrm{L}(\mathrm{t}) \mathrm{pr} \rightarrow \mathrm{Y}(\mathrm{t})$;

$\mathrm{a}(\mathrm{t})$ er lig med de produktive lønarbejderes lønsum i forhold til lønsummen $\mathrm{W}(\mathrm{t}) \mathrm{L}(\mathrm{t})(\mathrm{a}(\mathrm{t})$ har her en anden betydning end i teksten);

$b(t)$ er lig med lønsummen for de uproduktive lønarbejdere i tjenesteydelsessektoren i forhold til den samlede lønsum;

$\mathrm{c}(\mathrm{t})$ er lig med lønsummen for de statslige lønarbejdere i forhold til den samlede lønsum.

Når b(t) og c(t) vokser mere end $a(t)$ følger det, at $\frac{\mathrm{a}(\mathrm{t}) \mathrm{W}(\mathrm{t}) \mathrm{L}(\mathrm{t})}{\mathrm{Y}(\mathrm{t})}$ falder, mens merværdiraten for de produktive arbejdere $\frac{\mathrm{P}}{\mathrm{W}(\mathrm{t}) \mathrm{prL}(\mathrm{t}) \mathrm{pr}}$ $=\frac{\mathrm{Y}(\mathrm{t})}{\mathrm{a}(\mathrm{t}) \mathrm{W}(\mathrm{t}) \mathrm{L}(\mathrm{t})} \div 1$ stiger

Dvs. at de produktive lønarbejderes merværdirate stiger, når de uproduktive lønarbejderes lønsum vokser hurtigere end den samlede nyværdi. Denne sammenhæng belyser vi ved hjælp af de følgende empiriske data. Som indikator på størrelsen af hver af lønarbejdergruppernes lønindkomst tager vi deres »bidrag « til bruttonationalproduktet, som vi kan tage direkte fra statistikken (B angiver at størrelsen er beregnet ud fra bidraget til BNP).

$\left(\mathrm{a}_{\mathrm{B}}(\mathrm{t})+\mathrm{b}_{\mathrm{B}}(\mathrm{t})+\mathrm{c}_{\mathrm{B}}(\mathrm{t})\right) \mathrm{Y}(\mathrm{t})$

Hvis $b_{B}$ og $c_{B}$ (= de uproduktive arbejderes bidrag) vokser $\mathrm{i}$ forhold til nyværdien (denne vækst betales af profitten eller (for de statslige lønarbejdere) af profit og løn), kan man heraf slutte, at de produktive lønarbejderes merværdirate ikke længere kommer til udtryk i en stigende eller konstant lønkvote. Det er tilfældet, når merværdiraten selv stiger, fordi de uproduktive lønarbejdere absorberer mere end proportionalt af nyværdien.

Bidrag til bruttonationalproduktet i milliarder DM (løbende priser) (efter Görzig m.fl. 1973, s. 70f):

Sektor

Forarbejdning

Handel, transport, tjenesteydelser

heraf tjenesteydelser

Staten, privat husholdning, organisationer o.l.
1950

42,18

39,73

10,64

10,24
1970

293,05

281,99

96,23

73,30
Ændring i \%

700

710

905

715

Statistikken viser, at $b_{B}$ og $c_{B}$ vokser mere end $a_{B}$ ! Deraf følger, at de uproduktive lønarbejdere er vokset mere end de produktive, og at de gør større krav på nyværdien og lønsummen, end hvad der svarer til væksten i disse størrelser. Enten udtrykker en konstant lønkvote altså en stigende udbygningsgrad 
eller - hvilket er vores konklusion - en stigende lønkvote udtrykker en ligeså stærk eller stærkere stigning i merværdiraten. Et yderligere resultat af vor undersøgelse er: de uproduktive lønarbejderes stigende andel af nettoproduktet mindsker den akkumulerbare profit og indskrænker den mulige kapitalvækst.

\section{Litteratur}

Adam, Hermann. 1972: Die konzertierte Aktion in der Bundesrepublik. Köln. Agnoli Johannes, 1973: Zur Faschismus-Diskussion. Hamburg.

Ahnefeld. A., 1972: Neuere Versuche mit der Einkommenspolitik. Die Weltwirtschaft, Heft 1; S. 20-40.

Albers, Detlev; Goldschmidt, Werner; Oehlke, Paul, 1970: Klassenkämpfe in Westeuropa. Reinbek bei Hamburg.

Altvater, Elmar, 1973: Om nogle problemer ved statsinterventionismen. Kurasje nr. 7.

-, Hoffmann, Jürgen; Semmler, Willi; Schöller, Wolfgang, 1973: On the Analysis of Imperialism in the Metropolitan Countries - the West German Example, Oplæg ved Conference of Socialist Economists (CSE). London (BCSE, Spring 1974)

-, 1975: Kapitalismens udviklingstendenser i Vesttyskland. Kurasje 12 og 13.

-, Brandes, V; Reiche, J, 1975: Handbuch 4 - Inflation, Akkumulation, Krise II. Frankfurt / M.

Bergmann, Joachim, 1973: Organisationsinterne Prozesse in kooperativen Gewerkschaften. Leviathan Nr. 2.

Blanke, Bernhard: Kastendiek, Hans; Jürgens, Ulrich, 1973: Zur marxistischen Diskussion über Form und Funktion des Staates. Referat auf dem Kongreßs der Deutschen Vereinigung für Politische Wissenschaft vom 1. bis 4. Oktober 1973 in Hamburg.

Blackaby, Frank, 1972: An Incomes Policy for Britain. London.

Cassel, Dieter, 1972: Die Ultima ratio im Kampf gegen die Inflation. Wirtschaftswoche Nr. 44/1972.

CGIL/CISL, 1973: Zur Geschichte und Theorie der italienischen Gewerkschaftsbewegung (2 Bde). Berlin.

Dall'Asta, E. R., 1971: Theorie der Lohnpolitik, Berlin.

Denison, E. F., 1967: European Economic Growth and the U. S. Postwar Record. Highlights of Why Growth Rates Differ. Washington.

Deutscher Gewerkschaftsbund (DGB), u.å.: Protokoll des außerordentlichen Bundeskongress des DGB 1963.

Fellner, W., u.a., 1961: The Problem of Rising Prices. Paris.

Funke, Hajo m.fl., 1974: Lønformer og intensivering af arbejdet. Århus 
Gahlen, Bernhard, 1973: Verteilungskampf und Reformpolitik. Gewerkschaftliche Monatshefte Nr. 9.

Görzig Bernd; Kirner, Wolfgang, 1973: Möglichkeiten und Grenzen einer mittelfristigen Einkommenspolitik im Rahmen einer allgemeinen Wirtschaftspolitik. DIW-Beiträge zur strukturplanung, Heft 25. Berlin.

Haberler, Gottfried, 1972: Ohne Geldpolitik erfolglos. Wirtschaftswoche Nr. 47/1972.

Hansen, Alvin, 1947: Amerika in der Weltwirtschaft. Wiesbaden.

-, 1957: The American Economy. New York.

Hofmann, Werner, 1962: Die Säkulare Inflation. Berlin.

Institut für Sozialforschung, 1969: Zwischenbericht über den Stand der Arbeiten am Forschungsprojekt »Die Funktion der Gewerkschaften im Prozeß der gesellschaftlichen Entwicklung Westdeutschlands«. Frankfurt/M.

Janossy, Franz, 1966: Das Ende der Wirtschaftswunder. Frankfurt/M.

Kadritzke, Niels, 1973: Faschismus als gesellschaftliche Realität und als unrealistischer Kampfbegriff. Probleme des Klassenkampfs Nr. 8/9.

Kalecki, Michael, 1943: Political Aspects of Full Employment. Political Quarterly vol. 1943; her citeret efter: Hunt, E.K. and Schwartz, Jesse G., 1972: A Critique of Economic Theory. Harmondsworth.

-, 1971: Class Strugle and Distribution of National Income. Kyklos. Vol. XXIV Keynes, John M., 1936: Allgemeine Theorie der Beschäftigung, des Zinses und des Geldes, Berlin.

-, 1940: How to Pay for the War. Hier zitiert nach R. J. Ball and Peter Doyle (eds.), 1969: Inflation. Harmondsworth.

Kidron, Michael, 1971: Rüstung und wirtschaftliches Wachstum. Frankfurt/M. Kindleberger, Charles P., 1967: Europe's Postwar Growth. The Role of Labour Supply. Cambridge.

Krelle, Wilhelm, 1972: Die Opfer für stabilitätskonforme Lohnpolitik. Wirtschaftswoche Nr. 49/1972.

Läpple, Dieter, 1973: Staten og de almene produktionsbetingelser. København. Lindner, Gudrun, 1973: Die Krise als Steuerungsmittel. Leviathan Nr. 3.

Machlup, Fritz, 1971: »Rückkehr zur alten Parität hieße für die Bundesrepublik Wiederanschluß an die Weltinflation « (Interview). Wirtschaftswoche Nr. 31/1971.

Mandel, Ernest, 1972: Der Spätkapitalismus. Frankfurt/M.

Mattick, Paul, 1973: Marx og Keynes. København.

Müller-Jentsch, Walter, 1973: Bedingungen kooperativer und konfliktorischer Gewerkschaftspolitik. Leviathan Nr. 2. 
Nuti D. M., 1969: On Incomes Policy. Science and Society, Vol. 33; her citeret efter: Hunt, E. K. and Schwartz, Jesse G. (eds.): A Critique of Economic Theory. Harmondsworth.

OECD, 1970 a: The Growth of Output 1960-1980.

-, 1970 b: Inflation. The Present Problem.

Pigou, A. C., 1933: The Theory of Unemployment. London.

Redaktionskollektiv Gewerkschaften, 1972: Thesen zur Gewerkschaftsanalyse. Probleme des Klassenkampfs Nr. 2.

Reuss, Frederik G., 1963: Fiscal Policy for Growth without Inflation: The German Experience. Baltimore.

Roskamp, Karl W., 1965: Capitalformation in Germany, Detroit.

Sachverständigenrat, 1969: Jahresgutachten 1969 (Bundestagsdrucksache VI/100). Bonn-Bad Godesberg.

-, 1973: Jahresgutachten 1973 (Bundestagsdrucksache 7/1273). Bonn-Bad Godesberg.

Salvati, Michele, 1972: Der Ursprung der gegenwärtigen Krise in Italien. Probleme des Klassenkampfs Nr. 4.

Schefold, Bertram, 1973: Wert und Preis in der Marxschen und in der Neokeynesianischen Akkumulationstheorie. Mehrwert Nr. 2.

Schlecht, Otto, 1968: Konzertierte Aktion als Instrument der Wirtschaftspolitik. Tübingen.

Schöller, Wolfgang, 1973: Werttransfer und Unterentwicklung. Probleme des Klassenkampfs Nr. 6.

Semmler, Willi; Hoffmann, Jürgen 1972: Kapitalakkumulation, Staatseingriffe und Lohnbewegung. Probleme des Klassenkampfs Nr. 2.

Schonfield, Andrew, 1969: Modern Capitalism. Oxford.

Sohn-Rethel, Alfred, 1973: Ökonomie und Klassenstruktur des Faschismus. (Udgivere: J. Agnoli, B. Blanke og Niels Kadritzke). Frankfurt/M.

Trade Union Congreß, 1967: Incomes Policy. Report of the Conference of Executive Commitees of Affiliated Organisations held on March 1967.

United Nations (Secretariat of the Economic Commission for Europe), 1967: Incomes in Postwar Europe: A Study of Policies, Growth and Distribution. Geneva.

Vogt, Winfried, 1973: Zur langfristigen ökonomischen Entwicklung eines kapitalistischen Systems, Leviathan Nr. 2.

Wallich, Henry C., 1955: Triebkräfte des deutschen Wiederaufbaus. Frankfurt/M. 


\section{ET UPUBLICERET MARX-MANUSKRIPT OM VIDENSKAB OG KAPITAL}

Den Marx-tekst, som vi her publicerer for første gang, ${ }^{1}$ stammer fra de forberedende arbejder til Kapitalen, som blev skrevet i 1863. ${ }^{2}$ Marx bestemmer her videnskabens rolle og placering i det kapitalistiske samfund.

Han viser, at naturkræfterne $\mathrm{i}$ og for sig intet koster, da de ikke er et produkt af det menneskelige arbejde. Men under kapitalistiske betingelser tilegner kapitalisterne - ejerne af produktionsmidlerne - sig disse gratis naturrigdomme ved hjælp af naturvidenskaberne. Således bliver videnskaberne som naturbeherskelsesmiddel under kapitalismen et middel til produktion af rigdom for den herskende klasse, altså et berigelsesmiddel for denne. Derfor fremhæver Marx overordentlig kraftigt, at videnskaben, menneskeheden teoretiske fremskridt, bliver udbyttet af kapitalismen: kapitalen, som ikke selv skaber videnskaben, udbytter denne og tilegner sig dens frugter.

Marx forklarer derefter, at hvis den kapitalistiske produktionsmåde på den ene side gør naturvidenskaberne til en faktor som tjener produktionsprocessen, så skaber udviklingen af produktionen på den anden side midler til den »teoretiske beherskelse af naturen «.

Overordentlig stor betydning må tillægges den tese som Marx fremsætter, ifølge hvilken videnskaben under kapitalismen er fremmed og fjendtlig over for arbejdet, at den underkaster sig dette, og at den bidrager til forstærkelse af kapitalens udbytning af arbejderklassen. På samme måde som udviklingen af produktionsbetingelserne og deres transformation til kapital hviler på adskillelsen mellem disse produktionsbetingelser og arbejderne, således hviler anvendelsen af videnskaben i den kapitalistiske produktionsproces på adskillelsen mellem de intellektuelle kræfter og arbejderne, dvs. på kvælningen af arbejdernes åndelige evner. Konklusionen i dette fragment begrunder endvidere yderligere hvorfor videnskaben under kapitalistiske betingelser gennemløber en bestemt udvikling.

Marx' konklusioner og teoretiske bemærkninger omkring videnskabens og teknikkens udvikling under kapitalismen er fuldt ud bekræftet af praksis. Under kapitalismens aktuelle betingelser betyder videnskabens og teknikkens

1. I tidsskriftet Kommunist, Moskva, 1958, nr. 8. På russisk. Oversat her (La Nouvelle Critique, nr. 100, november 1958 o.a.) efter fotokopi af den tyske original, som venligst er videregivet af Instituttet for marxisme-leninisme ved Centralkomiteen for SUKP, til hvem vi retter en hjertelig tak (Redaktionel note af La Nouvelle Critique).

2. Se især Kapitalen, fransk udgave, 1. Bind, 2. bog, s. $71 \mathrm{ff}$. Editions Sociales, 1948. 
fremskridt altid - med et udtryk af Lenin - et fremskridt i »kunsten at få sveden til at springe frem $\ll$.

Instituttet for marxisme-leninisme ved SUKP's Centralkomité. ${ }^{3}$

3. Denne udgivelse er forberedt af Instituttets videnskabelige medarbejdere S. M. Grigorian og I.

T. Kharitonov.

\section{KOMMENDE UDGIVELSER}

KURASJE udgiver i september 1976 følgende bøger:

INFLATION OG KRISE

En antologi med følgende bidrag:

- E. Altvater, J. Hoffmann, R. Künzel og W. Semmler: Inflation og kapitalvaloriseringens krise,

- Olaf E. Dombrowsky: Kritik af borgerlige inflationsteorier, og

- Paul Mattick: Den deflationære inflation. ca. 200 sider.

Christel Neusüss:

Imperialisme og det kapitalistiske verdensmarked ca. 250 sider.

Kurt Aagaard Nielsen:

Kvalifikationsstruktur og klassestruktur

ca. 120 sider.

Rudi Schmiede:

Akkumuler, Akkumuler! Det er Moses og profeterne!

Grundlæggende problemer i den marxske akkumulations- og kriseteori.

ca. 200 sider.

Jindrich Zeleny:

Videnskabslogikken i Kapitalen ca. 120 sider.

KURASJE vil den 1. september udsende et nyt katalog med oplysninger om priser og nøjagtige udgivelsesdatoer. Kataloget kan bestilles og vil blive tilsendt portofrit.

\section{KURASJE,}

Krystalgade 14/16, 1172 København K.

Giro: 7166044 


\section{VIDENSKAB OG KAPITAL ${ }^{4}$}

\section{KARL MARX}

Masseproduktionen - eller kooperation i stor målestok med anvendelse af maskineri - har sit udspring i, at naturkræfterne - vind, vand, damp, elektricitet - i stort omfang underlægges den umiddelbare produktionsproces: masseproduktionen transformerer disse til agenter for det samfundsmaessige arbejde (i agrikulturen under dens prækapitalistiske former fremtræder det menneskelige arbejde snarere blot som hjælpemiddel for naturprocesserne, som det ikke er i stand til at kontrollere). I og for sig koster disse naturkræfter intet; de er ikke et produkt af menneskeligt arbejde. Men tilegnelsen af dem kan kun ske ved hjælp af maskinerne, som på deres side koster noget, i og med at de er produkt af et allerede udført arbejde. Som agenter for det samfundsmæssige arbejde bliver naturkræfterne således kun tilegnet ved hjælp af maskinerne og disses ejere.

Da disse natural-agenter intet koster, indlemmes de i arbejdsprocessen uden dermed at indlemmes i værdiproduktionsprocessen. De forhøjer arbejdets produktivkraft, men uden at forhøje produktets vaerdi, uden at føje noget til varernes værdi. Tværtimod, [værdien af] hver enkelt vare taget for sig formindskes, fordi massen af de varer, der produceres inden for den samme arbejdstid for$\emptyset$ ges, og fordi vardien af hver alikvot del af denne masse følgelig formindskes. I den udstrækning disse varer indgår i arbejdskraftens reproduktion vil værdien af denne arbejdskraft formindskes. Med andre ord: den for reproduktion af arbejdslønnen nødvendige tid vil være forkortet og merarbejdstiden forlænget. Det er i denne betydning at naturkræfterne ser sig tilegnet af kapitalen; det forholder sig altså ikke således, at disse forhøjer varernes værdi: tværtimod, de sænker disses [værdi], og de indgår i arbejdsprocessen uden at indgå i værdiproduktionsprocessen. Den udstrakte anvendelse af naturkræfterne er kun mulig, hvor maskineriet selv benyttes i stor målestok, og hvor der følgelig optræder en tilsvarende koncentration af arbejdere, og disse arbejderes kooperation er underkastet kapitalen.

Udnyttelsen af natural-agenterne - $\mathrm{i}$ et vist omfang deres inkorporering $\mathrm{i}$ kapitalen - falder sammen med videnskabens udvikling som autonom faktor i produktionsprocessen. Når produktionsprocessen bliver en anvendelse af videnskaben, bliver videnskaben omvendt en faktor i, eller så at sige en funktion af produktionsprocessen. Enhver opfindelse danner grundlag for en ny fremgangsmåde, en ny forædling af produktionsmetoderne. Det er først med den kapitalistiske produktionsmåde, at videnskaben stilles til rådighed for den

\section{Redaktionel overskrift, Kurasje.}


umiddelbare produktionsproces, hvor produktionens udvikling imidlertid skaber midlet til teoretisk at beherske naturen. Først da får videnskaben til opgave at være et middel til produktion af rigdomme, et middel til berigelse.

Det er med denne produktionsmåde, at der for første gang opstår praktiske problemer, som kun kan løses videnskabeligt. Først fra dette tidspunkt nødvendigg ør selve produktionsprocessen, at der gøres eksperimenter og observationer på et niveau som tillader, som endog fordrer anvendelse af videnskaben, udnyttelse af videnskaben i menneskehedens teoretiske fremskridt. Kapitalen skaber ganske vist ikke videnskaben, men den udnytter den, idet den inkorporerer den i produktionsprocessen. Men samtidig sker der en adskillelse mellem videnskaben, forstået som videnskaben anvendt i produktionen, og det umiddelbare arbejde. I modsætning hertil er summen af viden (connaissances) begrænset på de tidligere stadier af produktionen, eksperimenterne er umiddelbart forbundet med selve arbejdet, og videnskaben kan ikke udvikle sig som en autonom kraft, der er adskilt fra arbejdet. Således omfatter videnskaben totalt set ikke mere end den receptmængde, som overføres af traditionen, og den udvikler sig kun ganske langsomt og i lille målestok (empirisk oplæring i hvert fags »hemmeligheder «). Ånden og hånden er endnu ikke adskilte.

Hr. Howell (en af fabriksinspektørerne) siger (Reports, etc. for the half year ending 31 st October 1856, s. 53): »Ifølge de største autoriteter inden for området skulle fabriksarbejdet vare en art lavere tvangsarbejde, som ikke fordrer anvendelse af [arbejdernes] åndelige evner « og han citerer med disse ord fabriksejerne selv: »Arbejderne burde altid holde sig for øje, at deres arbejde er en lavere form af det specialiserede arbejde, og at der ikke findes noget, som det er lettere at opnå færdighed i, eller bedre betalt $\mathrm{i}$ forhold til dets kvalitet. Ejheller findes der noget [arbejde], som en hurtig og billig læretid kan skaffe hurtigere og i større mængde... Fabriksejernes maskiner spiller $i$ realiteten en langt vigtigere rolle i produktionen end arbejdet og arbejderens kvalifikationer, hvor uddannelsen varer seks måneder, og som er inden for en hvilken som helst arbejders rækkevidde.« Side 17, The Masters Spinners and Manufacturers' Defence Fund, »Kommisionsrapport vedrørende oprettelsen og fordelingen af disse fonds ved Centralsammenslutningen af Spindemestre og Fabrikanter«.

Ordet fabrik, som det nævnes i interpretationsklausulen i Factory Act af 1844 (Victorias 7. regeringsår, artikel 15, § 73), er defineret således: »Ved ordet fabrik forstås bygninger og lokaliteter i eller inden for hvis rammer damp, vand eller en hvilken som helst anden mekanisk kraft anvendes til at bevæge eller igangsætte maskiner tjenende til udvindelse, forarbejdning eller færdiggørelse, eller til en hvilken som helst forarbejdningsproces af bomuld etc «. (Om genstanden, som her medvirker til at gøre fabrikken til en fabrik, er bomuld, uld, hestehår, silke, hør, hamp eller jute må naturligvis henføres til de lokale betingelser: dette vedrører ikke fabrikkens væsen). Når maskinerne 
her betegnes som »fabriksejerens maskiner«, når deres funktion assimileres til hans funktion i produktionsprocessen (»the business of production«), så forholder det sig på absolut samme måde med videnskaben, som er inkorporeret i disse maskiner, i fabrikationsprocesserne eller i de kemiske processer etc. Videnskaben træder op som en fremmed og fjendtlig magt over for arbejdet, en magt som underlaegger sig arbejdet. Videnskabens anvendelse - på den ene side koncentrationen; på den anden transformationen af viden, af observationer, af de empirisk overførte faghemmeligheder til videnskab, til analyse af produktionsprocessen ved hjælp af anvendelse af naturvidenskaberne i den materielle produktionsproces - dens anvendelse hviler således på adskillelsen mellem lærdommens åndelige kræfter og den individuelle arbejders viden og dygtighed; på samme måde hviler koncentrationen og udviklingen af produktionsbetingelserne og disses transformation til kapital på den kendsgerning, at arbejderen er frarøvet og adskilt fra de selvsamme produktionsbetingelser. Fabriksarbejdet overlader ikke arbejderen meget andet end kendskab til begrænsede håndbevægelser. Med fabriksarbejdet ophæves oplæringens love; den kamp som staten etc. fører for at de unge arbejdere i det mindste lærer at læse og skrive, viser, at denne anvendelse af videnskaben i produktionsprocessen falder sammen med kvælningen af enhver åndelig udvikling i fabrikationsakten. Ganske vist uddanner man et lille antal kvalificerede arbejdere, men dette er for intet at regne i sammenligning med massen af »dekultiverede « arbejdere.

På den anden side står to ting klart.

Naturvidenskabernes egen udvikling (og de udgør grundlaget for enhver videnskab), såvel som al viden i relation til produktionen, foregår på basis af den kapitalistiske produktion, som for første gang skaber størstedelen af videnskabernes materielle midler til forskning, observation og eksperimentering. I den udstrækning videnskaben benyttes af kapitalen som berigelsesmiddel, hvorigennem den bliver et berigelsesmiddel for de, der udvikler den, i samme udstrækning vil videnskabsmændene indbyrdes konkurrere om at finde dens praktiske anvendelse. På den anden side bliver opfindelsen et selvstændigt erhverv. Det er under disse betingelser, at den videnskabelige faktor med den kapitalistiske produktion gennemløber en bevidst udvikling, at den anvendes og drives fremad i en målestok, som de tidligere epoker ikke havde nogen forestilling om. 


\section{teori og klassekamp}

TEORI \& KLASSEKAMP er et nyt märxistisk tidsskrift, som udgives af Engelsk Fagfront ved Københavns Universitet.

Formålet med TEORI \& KLASSEKAMP er at bidrage til at holde liv i den marxske videnskabs revolutionære kritikkraft på et tidspunkt, hvor den ikke er materielt forankret i arbejderklassen. Dette gøres ikke - som i en fremherskende tendens på venstrefløjen - ved at bannerføre 'ned med teorien, op med praksis'. Eftersom venstrefløjen domineres af mellemlag, bliver denne praksis nemlig uvægerligt vores lagsspecifikke praksis - ikke arbejderklassens. Når arbejderklassen kæmper, da - og først $\mathrm{da}$ - er de venstreorienteredes opgave politisk givet.

TEORI \& KLASSEKAMP $\mathbf{1 - 2}$ indeholder:

Erik Wienberg: INTRODUCERENDE BEMÆEKNINGER TIL MELLEMLAGSPROBLEMATIKKEN

Gerhard Armanski: STATSLIGE LØNARBEJDERE I KAPITALISMEN

Randi Hedetoft \& Nanna Hvidt: OM KVINDEBEVÆEGELSEN I MELLEMLAGENE

Gerhard Vinnai: SOCIALISATION SOM PRODUKTION AF VAREN ARBEJDSKRAFT

UIf Hedetoft: REPRODUKTION OG BEVIDSTHEDSDANNELSE I ARBEJDERFAMILIEN

Dann Simonsen \& Jeff Snider: ANMELDELSE AF 'SOCIALISTISK POLITIK' NR. 1

TEORI \& KLASSEKAMP bestræber sig - positivt bestemt - på at oparbejde det arbejderstandpunkt, som kritikken af den politiske økonomi indeholder, helt frem mod kapitalakkumulationens historisk-konkrete former. Eller med andre ord: at fastholde kapitallogikkens konstituerende betydning for klassedynamikken. Vi sympatiserer med arbejdet med en reorientering af marxismen mod empirien, men vel at mærke: for så vidt dette sker uden opgivelse af det marxske fremstillingsideal. Artikler i de kommende numre vil ligge inden for dette spektrum: krise-, statsog klasseanalyse.

TEORI \& KLASSEKAMP koster i øøssalg (som besørges af KURASJE) pr. enkeltnummer $12,50 \mathrm{kr}$. og pr. dobbeltnummer 25,00 kr. ABONNEMENT for numrene 1-4 tegne ved indbetaling af $37,50 \mathrm{kr}$. til:

TEORI \& KLASSEKAMP

Thorsagde 13, IV. tv. 2200 N. GIRO 7289898

BENYT VEDLAGTE GIROKORT!!!

"At kapitallogikken i sin mere platte udgave dog langtfra er afgået ved en stille død, vidner f.eks. Engelsk Fagfronts nye tidsskrift 'Teori og Klassekamp' særdels overbevisende om«.

SOCIALISTISK POLITIK nr. 3 Lisbeth Gunlund Jensen \& Just Justesen 


\title{
STATEN OG \\ GENNEMSNITSPROFITRATEN
}

\author{
Ole Fogh Kirkeby
}

\section{Forord}

I den følgende tekst skal statens funktioner i det kapitalistiske samfund bestemmes ud fra niveauet-for-kapitalen-i-dens-realitet, altså ud fra konkurrencens begreb. Det betyder, at statens funktion overfor totalkapitalen - der jo kun har karakter af en abstrakt funktionssammenhæng - går igennem enkeltkapitalerne, og at statens mål og midler skal forstås i forhold til enkeltkapitalerne og disses organisering i sektorer og brancher.

Statens historiske funktion fra begyndelsen af det 19-nde århundrede har været at opretholde den privatretslige basis, der udgør kapitalismens fundament, når denne basis blev truet brugte staten magt og klassemodsætningerne var udtalt på overfladen. Men som det kapialistiske samfund har udviklet sig har statens funktion fået en langt mere legitimerende og instrumentalistisk karakter, også selvom dens funktioner stadigvæk er de samme: opretholdelsen af de basale ejendomsforhold er kun mulig hvis kapitalvaloriseringen fungerer nogenlunde glat, dvs. hvis $\emptyset$ konomisk vækst kan stabilisere de modsætninger hvorover samfundet består.

I selve de objektive love hvorigennem kapitalrelationen reproduceres ligger der - på baggrund af det parlamentariske systems institutionelle og politiske rammer - en række fremtrædelsesformer, eller tankeformer af »objektiv karakter «, der følger af individernes praksis under kapitalismen og ifølge deres væsen bekræfter kapitalismen som et system hvori de forskellige gruppers materielle interesser tilgodeses effektivt, ja måske bedst. 
I slutningen af bd. III af Das Kapital og i slutningen af bd. III af Theorien über den Mehrwert findes der passager, hvori Marx under betegnelsen »revenukilde « søger at bestemme de former, hvorunder kapitalforholdet på det konkreteste plan af samfundsprocessen fremtræder for de implicerede, således, at der $i$ formen for fremtrædelsen er indbygget en legitimation af kapitalens eksistens.

Kapital, arbejde og jordejendom fremtræder - siger Marx - som ligestillede indtægtskilder, der - trods stoflige forskelligheder - yder kvalitativt samme præstation ved totalproduktets skabelse. Arbejdet fremtræder altså ikke som kilden til al brugsværdi og værdi (jeg ser her bort fra »naturens « rolle ved skabelsen af brugsværdier) men også kapital og jord fremtræder som umiddelbart værdiskabende.

At kapitalen fremtræder således kan først forstås når vi har gennemtænkt konkurrencens former og rentekapitalen: for i konkurrencen, dvs. i den proces, hvori gennemsnitsprofitraten og produktionspriserne dannes, fremtræder forholdet mellem summen af enkeltkapitaler og totalmerværdien således, at hver enkelt kapital får profit proportionalt med sin totale størrelse, og ikke i forhold til den værdimasse, som det arbejde skaber der er underkastet denne kapital. Både konstant og variabel kapital fremtræder som lige »produktive« ved skabelsen af værdi.

Rentekapitalen er ifølge Marx det mest ekstreme eksempel på hvordan kapitalens fremtrædelsesformer kan skjule det forhold, at det er arbejdet alene, der er kilde til al værdi i kapitalismen. Rentekapitalen er kapitalens mest abstrakte form, abstrakt i betydningen, at ethvert spor af kapitalens oprindelse er blevet udslukt. Passiv kapitalbesiddelse er her blevet forvandlet til en konstitutionsret til en del af totalproduktet. Ikke alene synes rentefoden en »naturlig « del af omkostningsprisen, et vederlag til besidderen af produktionsfaktoren »penge « for hans risiko men rentekapitalen synes produktiv på linie med industrikapitalen, den opfattes som samfundsnødvendig i egenskab af integrerende del af produktionen.

Kapitalens (i form af produktionsmidler og penge), jordejendommens og arbejdskraftens frugter opfattes som »revenu«, som indtægt, og det er nu den borgerlige stats opgave at sikre eksistensen af disse indtægtskilder, at sikre indtægtens størrelse og kontinuitet. Om disse abstrakte funktioner kan revenukildeejerne forenes på trods af de helt fundamentale modsætninger mellem dem.

Det har været von Flatow/Huiskens' fortjeneste at gøre opmærksom på revenukilde-illusionernes - også kaldet »den trinitariske formel « - rolle ved etableringen af samfundet som et fungerende fællesskab og staten som et aktionsdygtigt instrument. De har præciseret, at statens aktionsgrundlag, basis for dens selvforståelse og for de mål og midler den kan betjene sig af, er de former for legitimation, der er indeholdt i kapitalens egne formbestemmelser. ${ }^{1}$

1. Sibylle von Flatow/Freerk Huiskens: Zum Problem der Ableitung des bürgerlichen Staates. Die Oberfläche der bürgerlichen Gesellschaft, der Staat und die allgemeinen Rahmenbedingungen der Produktion. Probleme des Klassenkampfs, nr. 7, Mai 1973. Dansk oversættelse: Kurasje nr. 9 og 10. 
Men på trods af deres fortjeneste kan von Flatow/Huiskens ikke besvare flere alvorlige problemer $\mathrm{i}$ forbindelse med bestemmelsen af statens rolle $\mathrm{i}$ kapitalismen: for den første kan den trinitariske formel ikke give det virkelige grundlag for den rationalitet indenfor hvilken staten handler, og for det andet er den trinitariske formel for abstrakt med henblik på de konkretere formbestemmelser, der kendetegner statens aktionsformer på niveauet for kapitalen-idens-realitet: her giver opspaltningen af kapitalen i industrikapital, handelskapital, pengekapital og rentekapital lejlighed til udkrystalliseringen af en række særinteresser, der kompletteret med dem, der udspringer af statens rolle på verdensmarkedet gør revenu-kildebegrebet til noget alt for abstrakt.

Men den trinitariske formel udgør trods alt kernen i statens legitimationsbasis, den udgør i vid udstrækning de briller hvorigennem staten fortolker samfundet og dermed sin egen aktivitet.

Det er da målet for denne artikel først at fremstille statens funktion i konkurrencen, altså dens rolle ved konstituteringen af udbuddet og efterspørgslen og dermed for dannelsen af gennemsnitsprofitraten på baggrund af en tre-sektor-model. Statens forbindelse med den økonomiske basis og dermed statsinterventionens objektive grundlag etableres gennem skabelsen af udbud og efterspørgsel på grundlag af konkurrencen mellem enkeltkapitalerne.

Efter rekonstruktion af dette objektive grundlag, dvs. efter fremstillingen af betingelserne for dannelsen af gennemsnitsprofitraten og produktionspriserne kan kapitalens konkretere forbestemmelser indenfor cirkulationssfæren fremstilles, her især med henblik på en klargørelse af kredittens funktion i en åben økonomi, altså sammenhængen mellem kredit, akkumulationsfond og gennemsnitsprofitrate.

Endelig kan på baggrund af denne viden statsinterventionens illusioner og rationelle kerne opspores, og her skelnes der mellem to former for statsintervention: den der fandt sted efter anden verdenskrig og som toppede ved krisen i 73-74 og den, der afløste denne traditionelle form for statsintervention, og som karakteriseres af kraftige standsninger i statens udbudefterspørgselsskabende funktioner: stop for byggeri, offentlige ansættelser, etc.

Afgørende er her hvilke totalforestillinger, der gør statens aktionsskifte muligt, dvs. hvilke fremtrædelsesformer for kaptialens formspecificeringer, der tvinger staten til at skifte midler i den $\varnothing$ konomiske politik.

Den metode jeg her benytter mig af er den Marx anvender i Das Kapital og i Theorien über den Mehrwert: det drejer sig om udviklingen af den objektive basis, altså om udviklingen af kapitalens begreb på alle niveauer, og derefter om bestemmelsen af de mål og midler som medlemmerne af det kapitalistiske samfund og dermed staten kan sætte sig gennem en rekonstruktion af deres erfaringsgrundlag. Dette foregår gennem en dialetisk bevægelse mellem empirisk systematisering af partiers, organisationers og videnskabsmænds illusioner og så kendskabet til en række objektive tankeformer, der kan deduceres ud af kapitalens fetichformer og som så kan tjene som forklaring på de faktiske illusioners nødvendighed. 
Illusionerne er ikke logisk nødvendige, men deres gennemslag som basale erfarings- og aktionsdogmer er afhængig af klassekampens konkrete udformning. En målbevidst artikulation af proletariatets klasseinteresser vil ikke gøre disse illusioner mulige som generelle tanke- og handlingskategorier. De hænger nøje sammen med arbejderbevægelsens revisionistiske praksis.

Årsagen til at den trinitariske formel er blevet den illusionsform, der kan forklare statens legitimationsbasis idag hører altså nøje sammen med udviklingen indenfor arbejderbevægelsens partier og organisationer, hvor et samspil mellem disse illusioner som objektive muligheder for erkendelsesog aktionsgrænser og så arbejderbevægelsens mål, midler og kamperfaringer er historiens drivkraft. I takt med at basis for deres opfyldelse er blevet skabt gennem en stigning i bruttonationalproduktet er arbejderens »materielle interesser « blevet mindre og mindre systemkritiske, den revolutionære horisont er blevet begrænset til lønkampe uden videre perspektiv.

Statens rolle i sen-kapitalismen er at gøre den fortsatte pacifisering af arbejderklassen materielt mulig ved at sikre nationalkapitalen, men denne rolle artikuleres for staten i en række isolerede konflikter, hvor forholdet til verdensmarkedet spiller en afgørende rolle. Påvisningen af hvordan statens rolle skabes uden at totalkapitalen har status af en handlekraftig enhed, men netop skabes gennem statens holdning til kapitalformernes særinteresser og til forholdene omkring arbejdskraftens reproduktion og skabes på en sådan måde, at ikke alene adskillige kapitalgruppers, men også totalkapitalens valorisering bringes i vanskeligheder, er det opgaven for denne artikel at belyse.

Statens intervention, der sker af hensyn til bevarelsen af den økonomiske basis, må således ifølge sit væsen i netop den handling, hvormed den sikrer denne basis' eksistens, forøge de modsigelser som er indeholdt i den. Staten er som instans selv underkastet modsigelserne i kapitalens væsen.

Når denne artikel focuserer på kapitalens bevægelser og afgrænser statens handlingsunivers ud fra revenukildebevidstheden, så er det et perspektiv, der er nødvendiggjort af statens gennemført borgerlige karakter og parlamentarismens feticheringsgrundlag. Men det er ikke et programmatisk perspektiv for en analyse af kapitalismen ud fra det proletariske standpunkt i den forstand, at netop denne indfaldsvinkel skulle være den eksklusive og omfattende rigtige.

Når jeg i min analyse af konkurrencens begreb udelukkende focuserer på forholdet mellem kapitaler, så udelukker jeg naturligvis den dimension af konkurrencen, der bestemmes af arbejderklassens aktionshistorie: tekniske forandringer i produktionsprocessen er selvfølgelig ofte svar på arbejdskraftens aktivitet og ikke blot en kapitaliststrategi, hvis omfang og indhold udtømmende kan beskrives ud fra kampen mellem kapitaler om markedsandele.

Perspektivet i denne artikel er dog et nødvendigt gennemgangsled ved etableringen af arbejderklassens aktionshistorie, idet kapitalisternes handlinger 
overfor arbejderklassen i vidt omfang er bestemt af den herskende konkurrence mellem kapitaler: jo lavere markedsværdinivo indenfor en branche, jo større konkurrence mellem kapitalerne altså, desto voldsommere virkningerne har spontane reaktioner fra arbejderside i produktionsprocessen.

Mit ærinde med denne artikel er at skabe den platform, hvorudfra kapitalisternes reaktioner på arbejderklassens aktioner virkelig kan systematiseres og erkendes i deres indre nødvendighed. Men forståelsen er naturligvis kun komplet når arbejderklassens aktionshistorie bliver målet for brancheog totalanalysen fra marxistisk hold. Jeg håber at have bidraget lidt til den her fra mit særegne og absolut ikke fyldestgørende perspektiv: for formålet med at skrive kapitalens historie er naturligvis kun at skrive arbejderklassens negative historie, dvs. at blotlægge de objektive rammer for og påvise den entydige mulighed af den modmagt, hvis levende virkelighed det er arbejderklassens aktionshistories formål at afdække med henblik på direkte aktion.

\section{Del I}

\section{Kapitel 1}

\section{Indledning:}

Denne artikel er et fors $\varnothing \mathrm{g}$ på at fremstille en af de nødvendige årsager til inflationen i senkapitalismen.

Dens udgangspunkt er kapitalens lovmæssigheder på nivoet for kapitalen i dens realitet, altså på det nivo, hvor konkurrencen mellem kapitaler indenfor og mellem brancherne behandles, og den følger Marx'fremstilling af forholdene i bd. III af Das Kapital og i bd. II af Theorien über den Mehrwert.

Der kan næppe være tvivl om at udviklingen i priserne i senkapitalismen står i den grelleste kontrast til udviklingen i arbejdets produktivitet. Der er tale om en omtrentlig ensartet udvikling $\mathrm{i}$ indekset for produktivitet og i indekset for forbrugerpriserne hvad angår de førende kapitalistiske nationer. Der er ingen proportionalitet mellem udviklingen af arbejdets produktivitet og så prisudviklingen: priserne stiger derimod med stigende arbejdsproduktivitet, og det gælder især halv- eller helfabrikata. 
Ifølge PPII s. 148 er produktiviteten per beskæftiget steget med næsten 60\% fra 1960 til 1972. Fra 1965 til 1972 stiger indeksværdierne for industrivarer hovedsageligt af dansk oprindelse med $43 \% .^{1}$

Det har været en tendens i de moderne analyser af inflationen at begrunde denne i udvidelser af penge- og kreditmassen i forhold til produktmassen. Denne antagelse går tilbage til Ricardos »kvantitetsteori $\mathrm{og}$ har sine moderne varetagere i den såkaldte »Chicago-skole« med Milton Friedman som sin væsentligste repræsentant. $^{2}$ Også på marxistisk grund har der hersket tvivl om inflationens årsager. Karakteristisk for den nyeste debat er Altvater, Hoffmann, Künzel og Semmler i deres fors $\emptyset \mathrm{g}$ på at opstille et alternativ til Hofmanns begreb »den sækulare inflation « ${ }^{3}$

Men afgørende for alle disse indfaldsvinkler - hvad enten de foregår på den subjektive eller på den objektive værditeoris præmisser - er, at de ikke formår at stille og løse problemet om inflationen i hele dets systematiske konsekvens. En løsning kan nemlig her kun udvikles på baggrund af den teoretiske forståelse af betingelserne for identitet og variation mellem værdi og pris.

Dette problem bliver først eksistent på det nivoet af Marx' analyse, der kaldes »nivoet for kapitalen i dens realitet«, eller »nivoet for de mange enkeltkapitaler «: det drejer sig om at udvikle værditeorien således, at man v.hj. af den og v.hj. af begrebet for kapitalen kan gøre omfattende og systematisk rede for alle væsentlige afvigelser mellem værdi og pris og for afvigelsesformens konstitutionssammenhæng.

Den marxistiske indfaldsvinkel må afvise både løn-pris-spiral-begrebet såvel som den kvantitetsteoretiske tilnærmelse som værende adækvate angrebsvinkler til en bestemmelse af inflationen. ${ }^{4}$

Inflationen må bestemmes ud fra kapitalens begreb, dvs. ud fra forholdet mellem produktionssfære og cirkulationssfære.

Ud fra dette perspektiv viser de mulige afvigelser mellem værdi og pris sig at være bestemt af tre faktorer: totalproduktets størrelse og værdi, merværdira-

1. Tiårsoversigten 1975 , s. 61.

2. Skolen kaldes også »monitaristerne«. For en kritik af denne tolkning af pengenes rolle i totalreproduktionen se Marx: Zur Kritik der politischen Ökonomie, Dietz Verlag, Berlin 1970. s. 164 ff. Marx kritiserer her Ricardos tese om at priserne er direkte proportionale med pengemængden. En glimrende fremstilling af de borgerlige inflationsteorier findes hos Olaf E. Dombrowsky: Zur Kritik bürgerlicher Inflationstheorien, Prokla, 17/18, 1975. (På dansk i: Inflation og krise, KURASJE 1976) En kvantitetsteoretisk pengeteori findes hos Siebke/Willms: Theorie der Geldpolitik, Springer Verlag, 1974.

3. Altvater, Hoffmann, Künzel, Semmler: Inflation und krise der Kapitalverwertung, Prokla 17/18, 1975. (På dansk i: Inflation og Krise, KURASJE 1976).

4. Det drejer sig her om det keynesianske inflationsbegreb. Dette begreb er til en vis grad programmatisk: inflationen opfattes som noget positivt, nemlig som et middel til at stimulere investeringerne og dermed den $\varnothing$ konomiske aktivitet gennem profitstabilisering via prisstigninger og til at stabilisere klasseforholdene ved at reducere reallønnen indirekte og ikke gennem direkte lønpres.

Et eksempel på en keynesiansk indfaldsvinkel på inflationsproblematikken er Do Trade Unions Cause Inflation? skrevet af D. Jackson, H. A. Turner og F. Wilkonson. Cambridge. 1975. 
ten og konkurrencen mellem kapitalerne indenfor og på tværs af brancherne. Muligheden for at kapitalistklassen v.hj. af prisstigninger kan kompensere for omkostningsstigninger er afgjort af klassekampens konkrete karakter: altså af mulighederne for arbejderklassens kompensationskrav gennem lønstigninger. Her er produktivitetsstigninger en afgørende faktor, men de kan ikke anskues ud fra den relative merværdi alene, idet denne kategori- hvis den skal overføres fra det abstrakte niveau »kapital i almenhed « og anvendes direkte på historisk og økonomisk materiale - blot kan angive forholdet mellem prisen på totalproduktet og så prisen på sektor II's varer (den sektor, hvori arbejderklassens konsumtionsmidler produceres) i sammenhæng med beskæftigelsesantal og produktivitetsudvikling. Stiger priserne mere i sektor II i forhold til produktmasse end det er tilfældet i resten af samfundet, så falder merværdiraten - hvis reallønnen er konstant.

Merværdiraten som konkretere kategori - og her drejer det sig især om »relativ merværdi « da arbejdsdagen jo er konstant idag - har bl.a. den svaghed, at den forudsætter at produktivitetsudvidelse sker gennem en udvidelse af maskinparken ved konstant eller kun i ringe grad faldende arbejdstimeantal og at den forudsætter den samme produktivitetsudvikling i alle sektorer. Er denne derimod forskellig vil det ikke være sikkert, at en produktivitetsudvidelse uden videre vil skabe mere merværdi for kapitalisten heller ikke selvom hans arbejderantal er konstant. Det var jo tilfældet i England op til kornlovenes ophævelse i 1847 og videre endnu, at landbrugsprodukternes værdi overhovedet ikke fulgte værdifaldet p.g.a. produktivitetsstigninger i industrisektoren. Det betyder, at udvekslingsforholdet mellem landbrugssektor og industrisektor i en sådan situation må anskues som en konstellation, hvor industriens produktivitetsstigninger kun kan føre til stigninger i merværdiraten ved fald $i$ reallønnen. For princippet i den »relative merværdi« er, at arbejderens realløn er konstant og at dens varemasse produceres billigere end tidligere p.g.a. tekniske forbedringer af arbejdsprocessen men med ensartet timeantal, således at kapitalisten kan få en større del af produktet til sin rådighed og dermed en større del af den producerede totalværdi. Dette forhold er indlysende, når vi taler om produktionen af skjorter, der direkte indgår i arbejderens konsumtionsfond, men det bliver vanskeligere at forstå, når det drejer sig om sektor-I-varer, f.eks. aksler til motorer. Her kræves et udvekslingsforhold mellem sektorerne: hvis det samme antal arbejdere på samme tid producerer dobbelt så mange aksler som tidligere p.g.a. nyt maskineri, så er merværdiraten steget til det dobbelte, og hver aksel er faldet til den halve nyværdi (jeg udelukker her overført værdi af simpelhedshensyn). Men hvis de konsumtionsmidlereller nogle af dem der udgør arbejderens konsumtionsfond ikke er faldet i værdi i samme forhold, så kræves der så mange flere aksler til at bytte ud for de nødvendige konsumtionsmidler til arbejderen, at merværdiraten slet ikke kan stige til det dobbelte, sådan som produktionssfære-forholdene antydede det - med mindre reallønnen falder.

Kort og godt: begrebet »relativ merværdi« kan kun bruges på baggrund af den sammentænkning af produktionens og cirkulationens begreber som alene Marx' 
principper for dannelse af produktionspriser og gennemsnitsprofitrate giver det. I denne artikel vil jeg da lade merværdirateproblematikken ligge og dermed i vid udstrækning klassekampen mellem kapitalister og arbejdere i dens lønpris-perspektiv og unders $\emptyset$ ge de faktorer i konkurrencen mellem kapitalerne, der er afgørende for prisstigninger i kapitalismen i forhold til produktivitetsudviklingen.

Men selve statsinterventionsperspektivet bringer selvfølgelig klassekampen ind, idet statsintervention i f.eks. boligsektoren i vid udstrækning er en aktivitet direkte fremkaldt af klassekampen. Klassekampen er altså ikke skudt til side her, den er kun undersøgt $i$ en af dens fremtrædelsesformer: kampen mellem de forskellige branche-kapitaler og mellem kapitalfraktionerne i samfundet i forhold til kapitalens formspecificeringer i produktionsog cirkulationssfære.

Marx’ siger helt utvetydigt, at værdibegrebet først får analytisk endegyldig kraft på niveauet for kapitalen-i-dens-realitet. Her bliver det nemlig et gennemsnitsbegreb, der angiver hvor stor en del af det samfundsmæssige totalarbejde, der under givne produktionsbetingelser kan fordeles på produktionen af en brancheartikel.

»Det er i det hele taget i skikkelse af markedsprisen og videre i den regulerende markedspris' eller markedsproduktionspris' skikkelse, at vareværdiens væsen kommer til udtryk, der nemlig ikke består $i$ at være bestemt gennem den individuelle, for en given enkeltproducent nødvendige arbejdstid ved produktionen af et givet varekvantum eller af en vareenhed, men er bestemt gennem den samfundsmæssigt nødvendige arbejdstid; gennem den arbejdstid, der er påkrævet for at producere det samfundsmæssige fordrede totalkvantum af den på markedet eksisterende varetype ved de samfundsmæssige produktionsbetingelsers givne gennemsnit.«(Das Kapital, bd. III, s. 654, min overs. OFK.)

Det er altså produktionsprisen, der kvantitativt afgrænser værdibegrebet, der udgør dets historiske konkretisering ved at overordne værdiproduktionen kapitalens begreb (se kap. 2.).

Analysen af værdibegrebet kræver derfor såfremt det skal have status af udfoldet forklaringskraftig kategori inddragelsen af cirkulationssfæren og produktionssfæren, dvs. inddragelsen af totalreproduktionsperspektivet: først gennem reproduktionen af samfunds- eller totalkapitalen får værdibegrebet et særligere indhold.

Det er især i det forhold hovedargumentet for værdi-pris-identiteten over en vis periode ligger:

Idet jeg så lidt som muligt vil foregribe det følgende kapitel må dog følgende bemærkes: det ligger i kapitalens væsen, at værdi og pris ikke kan variere permanent.

Dannelsen af gennemsnitsprofitraten og produktionspriserne vil forhindre at en given branches markedsværdiniveau permanent ligger så højt at stedsevarende ekstraprofitter er mulige, for andre kapitaler vil trænge ind i branchen og dermed vil markedsværdiniveauet falde og profitten normaliseres, dvs. det, der var årsagen til værdi-pris-forskellen, vil forsvinde.

Men hvad bestemmer gennemsnitsprofitraten? Det gør totalmerværdien divideret med gennemsnitskapitalen. Da profitten immervæk må hente sit indhold fra totalmerværdien (fordi den må hente det i totalproduktionen) så findes der en »naturlig « grænse - på et givet tidspunkt- for profitniveauet både opad 
og nedad. I et lukket nationalt system, hvor vi ser bort fra kreditten og regner med at pengeudstedelsen følger produktionen (hvilket er det samme som at sige at pengeværdien er konstant - hvis vi sætter guldværdien konstant), vil kapitalens væsen altså blokere for værdi-prisforskellen som et afgørende fænomen hvad angår pris- og profitniveauets årsager over længere tid. (At produktionsprisbegrebet sætter sig igennem gennem en forskel mellem værdi og pris har intet med dette at gøre... (se fremme)).

På internationalt plan derimod bevirker det internationale betalingssystem og kreditsystem at en forskel mellem værdi og pris er mulig over et vist interval, men kun med alvorlige konsekvenser for landets $\varnothing$ konomi.

Det er altså ikke muligt gennem prismasser, der ingen værdimæssig dækning har eller gennem »importerede« værdimasser, der ingen brugsværdidækning har i cirkulationen i det nationale system, at forøge totalmerværdien således, at profitraten kan forhøjes for alle eller blot for nogle kapitalgrupper. Det er denne artikels indhold, at påvise grænserne for forøgelsen af visse kapitalgruppers merværdi gennem en statslig omfordeling af merværdimassen og gennem udpumpning af ikkeproduktionsmæssigt-dækket købekraft i totalreproduktionen. Det er altså statens interventions-former der undersøges på baggrund af konkurrencens væsen. Kun gennem modifikation af konkurrencen kan staten gribe ind i økonomien, men modifikationen udløser blot modsigelserne på et andet plan.

Statens intervention er på længere sigt begrænset af den nationale totalmerværdi og af valget mellem to onder: forfordeling af hjemlige kapitalgrupper med social og politisk uro som resultat eller skabelsen af svagheder i handelsog betalingsbalancen. Og de to onder hænger desværre sammen, så et valg ikke betyder en udelukkelse af den bortvalgte mulighed.

Forudsætningen for at behandle disse problemer er udviklingen af begrebet »totalkapital,« og det kan kun ske gennem udviklingen af gennemsnitsprofitraten, altså gennem en behandling af konkurrencen.

Staten forholder sig i sidste instans til totalkapital og totalarbejderklasse, men dens holdning går gennem aktion overfor kapitalerne indenfor de enkelte brancher og arbejderne indenfor de enkelte brancher og i de enkelte forbund.

Staten kan kun kommunikere med kapitalen sådan som kapitalen fremtræder i konkurrencen, det er dér deres tosomhed fuldbyrdes og parringen sker i sidste instans på kapitalens betingelser.

Skal man forstå hvordan staten handler i kapitalismen kan det da ikke nytte at opfinde en totalkapital som den handler overfor som sin partner - det er et fatamorgana, der smugler en rationalitet ind i historien, der ikke findes der. Staten må forholde sig til kapitalen som en branchespecifik og sektorspecifik kapital og som en kapital afgørende bestemt af de formbestemmelser den annammer i cirkulationssfæren.

Som sådan gribes forholdet da også her og artiklens pointe er da at forstå noget af inflationens væsen som fremkaldt af den interventionsnødvendighed, 
der ligger i statens væsen som formidler af modsætningen kapitalarbejde: Statens politisk bestemte efterspørgsel på produkter fra en række brancher i samfundet skaber konkurrencebetingelser i disse brancher, der bevirker, at der kan eksistere et meget højt markedsværdiniveau, små uproduktive virksomheder, og at de virksomheder, der har udviklet en høj produktivitet kan realisere store og stabile ekstraprofitter.

Herved såres princippet for dannelsen af gennemsnitsprofitraten i samfundet og de kapitalgrupper, der ikke nyder godt af statens efterspørgsel, kræver frihed, lighed og broderskab for alle kapitaler.

Det væsentlige her er bl.a., at der ikke er tale om nogen monopolsituation i den forstand, at brancherne skulle kunne lægge deres eget prisniveau eller råde over deres leverancer, etc. Prisniveauet er fuldkommen bestemt af efterspørgsels- og udbudsmekanismen og der siver kapital i rigt mål til brancherne.

Eksistensen af disse priviligerede brancher skaber en relativ stigning i omkostningsniveauet i samfundet og forværrer dermed kapitalernes situation både på hjemmemarkedet og på verdensmarkedet.

Før den egentlige fremstilling begynder er det på sin plads at begrunde, hvorfor jeg mener at inflationen som en af sine årsager har opretholdelsen af et kunstigt højt markedsværdiniveau og dermed som sin »materie « har »falsk social værdi « og ikke produceret værdi. (Disse begreber præciseres indgående i næste kapitel). Det er altså rimeligt kort at anføre, hvilke løsningsmuligheder jeg på forhånd har udelukket:

I) En årsag til den stigende priskurve i senkapitalismen kunne være det forhold, at simpelt arbejde forvandledes til kompliceret arbejde, dvs. at prismassen var dækket ind af en værdimasse, der faktisk var produceret.

En sådan antagelse, der bl.a. formuleres af S. L. Wygodski ${ }^{5}$, er totalt uacceptabel fordi den sammenblander produceret og realiseret merværdi. Ifølge den skulle ekstraprofitterne realiseret på grundlag af et givet markedsværdiniveau af de højproduktive firmaer være producerede. Det ville kort og godt betyde at totalmerværdimassen var uendelig at der ingen grænser fandtes for den, og at gennemsnitsprofitten ikke skabtes gennem en forskel mellem pris og værdi. Det ville betyde et opgør med hele værditeorien og en tilbageførsel af denne til Ricardos perspektiv, hvor der ikke systematisk sondres mellem individuel og samfundsmæssig nødvendig vareværdi. Endelig ville det bryde med hele Marx' akkumulationsteori og indebære at profitraten var absolut stigende i takt med akkumulationen. ${ }^{6}$

5. S. L. Wygodsky: Der gegenwärtige Kapitalismus, Versuch einer theoretischen Analyse, Pahl-Rugenstein, 1972.

6. Hvis man accepterede, at det var produceret værdi, der lå til grund for ekstraprofitterne, så ville man gøre profitten direkte proportional med v's størrelse og ikke med k+v, sådan som Marx tænker profitdannelsen i konkurrencen, hvor profitten netop er proportional med kapitalens absolutte størrelse uafhængigt af v's absolutte og relative størrelse. En sådan tese forudsætter enten at ligestore kapitaler ikke afkaster samme profit, med mindre de har præcis samme 
Flere argumenter er næppe nødvendige og fremstillingen i de næste kapitler vil forhåbentligt belyse det umulige i denne antagelse. Ellers vil jeg henvise til Ole Marquardts originale bidrag i Fagtryk. ${ }^{7}$

II) At prismassens stigning værdimæssigt skulle være dækket ind af faldende produktivitet eller stigende arbejdsintensivering er naturligvis en mulighed, men for det første er denne i modsætning til hele akkumulationsimperativet og dets måde at sætte sig igennem på i enkeltkapitalernes konkurrence. Desuden er de i modstrid med de empiriske data for de brancher, hvori prisniveauet er højest. Her foregår hele tiden en udvidelse af produktiviteten på arbejdets bekostning. Jeg henviser her igen til argumentationen i de kommende kapitler.

III) Endnu en mulighed for at forklare prisstigningerne i kapitalismen omvendt proportionalt med de faktiske produktivitetsstigninger ville være en tese om monopoliseringens store udbredelse og dens ineffektivitet i forhold til udviklingen af de samfundsmæssige produktivkræfter. Denne tese, der hører til »stamokaps « regi, men som også kan findes hos Hofmann og Baran-Sweezy, findes alene renset for sit politicistiske perspektiv på værdiloven og kapitalens jernhårde lovmæssigheder hos S. L. Wygodski. Denne forklarer monopolernes indvirkning på prisdannelsen gennem faktorer som bremsning af output, produktion ved underkapacitet, stigning i arbejdets udbytningsgrad, faktorer, der kan få markedsværdierne til at forblive konstante eller stige alt efter priserne på råvarer, maskiner og arbejdskraft. Ifølge Wygodski sker de faktiske produktivitetsstigninger i virksomheder udenfor monopolerne, hvor de sidste så bagefter overtager den nye teknik og udnytter den i begrænset grad alt efter profitniveauet.

Denne tese kan have en vis berettigelse i afgrænsede sammenhænge, men den rummer elementer der overser den udviklingssammenhæng, der ligger i kapitalens væsen. Samtidig mangler den evne til en systematisk belysning af statsinterventionismen og endelig er den empirisk irrelevant ved behandlingen af Danmarks erhvervsstruktur efter anden verdenskrig.

Hvorom alting er: den kapitalistiske udvikling, der udgør en udbredelse af kapitalrelationen til at dække hele samfundet og går i retning af at underlægge sig hele verdensøkonomien med ganske få - og væsentlige undtagelser - og der går i retning af en koncentration og vækst i den konstante kapital overfor arbejdskraften, denne udvikling sætter sig dog kun igennem via udviklingen i kapitalerne indenfor de enkelte brancher. Det er dér arbejderklassen møder kapitalen og det er herigennem kapitalen gennem sin organisering af produktionen af brugsværdier afgørende påvirker totalreproduktionen, og gør den til en reproduktion af sig selv i form af produktionsmidler og konsumtionsvarer.

arbejderantal af samme komplicerthedsgrad, eller at de - hvis de afkaster samme profit - enten tilfældigvis netop beskæftiger samme forhold kompliceret og simpelt arbejde, eller fordi den ene kapital beskæftiger en stor mængde simpelt og en lille mængde kompliceret arbejde, hvilket ækvivalerer med en vis mængde halvkompliceret arbejde.

7. En kommentar til den såkaldte reduktionsproblematik og dennes betydning for den marxske arbejdsværditeori. Fagtryk februar 1975. 


\section{Kapitel 2}

\section{Konkurrencens begreb}

Et udviklet samfunds produktion er opdelt i forskellige sektorer, der kendetegnes af produktionens formål i reproduktionens totalproces: landbrugssektor, bygge- og anlægssektor ect. Disse sektorer, der i den borgerlige bevidsthed afgrænses direkte efter dagligdagserfaringerne - og hvis videnskabelige berettigelse ikke skal diskuteres her - kan igen opdeles i brancher. Indenfor industrisektoren ${ }^{1}$ findes der f.eks. klynger af brancher, hvori der produceres kemiske artikler, elektroniske artikler, ect. og disse klynger kan igen opdeles i brancher, der afgrænses af et givet produkt: produktion af f.eks. batterier eller sovetabletter.

Branchebegrebet er altså afhængig af muligheden for at sammenligne en given produktion kvalitativt og kvantitativt, således at man kan udgå fra, at der vil dannes en enhedspris på produktet. Branchebegrebet er altså også afhængig af at branchens produkter har akkurat samme funktion indenfor den produktive eller private konsumtion.

Lad os i det følgende som eksempel på en branche tage cykelbranchen. Denne branche består måske af 9 virksomheder, der kan inddeles i 3 grupper på hver 3 virksomheder efter den organiske sammensætning af kapitalen i disse virksomheder ${ }^{2}$.

Vi kan nu opstille følgende skema hvis hver kapital antages at være på hundrede, eller hvis vi ser på hver kapital som et udsnit af 100. Den kapital der opereres med er overført kapital, d.v.s. at vi betragter den masse konstant og variabel kapital, der overføres til produktet gennem en dags produktion. At den egentlige kapital kan være større er selvsagt indlysende, men det spiller ingen rolle for argumentet. Vi antager også, at m’ er konstant.

1. Marx opererer med to eller tre sektorer i sin reproduktionsmodel, hvor han udgår fra hovedkomponenterne i produktionsprocessen: produktionsmidler og arbejdskraft og således har en produktionsmiddels- og en konsumtionsmiddelsektor. Men han opererer også undertiden med en tredie sektor, der dækker kapitalistklassens konsumtion, altså produktionen af luksusvarer.

Men i sin behandling af jordrenten stiller han landbrugssektoren og industrisektoren overfor hinanden, en modsætning, der går på tværs af det egentlige sektorbegreb i reproduktionsskemaerne.

2. Det er her afgørende, at»organisk kapitalsammensætning «refererer til»teknisk sammensætning«, altså at ens organisk sammensætning i systematisk forstand går på ens produktionskoefficienter. Dette understreges i kapital 10 og 11 i bd. III af Das Kapital og i behandlingen s. 774 af bd. III af Das Kapital.

For en god behandling af forholdet mellem værdimæssig og teknisk sammensætning af kapitalen, se Grossmann: Das Akkumulations- og Zusammenbruchsgesetz des kapitalistischen Systems, Archiv Sozialistischer Literatur 8, Frankfurt, 1970, s. 326-334. 


\begin{tabular}{|l|c|c|c|c|}
\hline Kapitaler & $\mathrm{m}^{\prime}$ & $\mathrm{m}$ & vareantal & $\begin{array}{c}\text { individuel } \\
\text { vareværdi }\end{array}$ \\
\hline A: $90 \mathrm{k}+10 \mathrm{v}$ & $100 \%$ & 10 & 10 & 11 \\
B: $50 \mathrm{k}+50 \mathrm{v}$ & $100 \%$ & 50 & 5 & 30 \\
C: $20 \mathrm{k}+80 \mathrm{v}$ & $100 \%$ & 80 & 1 & 180 \\
\hline
\end{tabular}

Hvis varerne sælges til deres individuelle værdi, og hvis hele denne realiseres, vil hver af kapital A's cykler blive solgt til værdien 11, B's til værdien 30, og C's til værdien 180. Af det antal cykler, som hver kapital producerede dagligt, fremgår det, at produktiviteten er direkte proportional med kapitalens organiske sammensætning: jo højere den er, desto højere er antallet af dagligt producerede enheder.

Problemet er nu, at enhver brancheartikel tenderer mod at blive solgt til en ensartet pris. Det er nemlig klart, at A ikke vil sælge sine cykler til en pris, der ligger på 11, når han ser at C sælger præcis den samme cykel til 180, altså til en værdi der ligger 16 gange over hans egen, ejheller vil vel nogen normal forbruger betale 16 gange så meget for den samme cykel?

Gennem den logiske mulighed for en afvigelse mellem pris og værdi - altså gennem det forhold, at en given pris ikke med logisk nødvendighed behøver udtrykke værdi, - vil der kunne dannes en enhedspris for ethvert brancheprodukt uafhængigt af den individuelle værdi af de varer, der produceres i branchen, eller rettere: afhængigheden viser sig indirekte gennem de love, hvorigennem vareværdierne regulerer priserne. Disse love ligger indenfor værditeoriens område, og derfor skal jeg i det følgende belyse, hvordan værdiens regulering af prisniveauet i brancherne og i hele samfundet faktisk sætter sig igennem.

Udgangspunktet er her det forhold, at pris og værdi, merværdi og profit kan variere på brancheplan, og må variere for at den dynamik, der ligger indbygget i kapitalens begreb kan fuldbyrdes: at kapitalen er værdiavlende værdi. Denne dynamik er kun helt gennemført i det øjeblik kapitalen kan afkaste profit i direkte forhold til sin absolutte størrelse, altså ikke blot i forhold til den arbejdermasse - ved given merværdirate ${ }^{3}$ - den kommanderer over. Dannelsen af en gennemsnitsprofitrate ligger således indbygget i kapitalens begreb, men

3. Årsagerne til at merværdiraten kan sættes konstant både empirisk og logisk behandles indgående i artiklen, her skal de kort ridses op:

Merværdiraten er konstant af logiske hensyn, fordi det ellers ikke er muligt at skelne mellem relativ merværdi og ekstra-merværdi og fordi man ellers ikke kan afgrænse værdibegrebet kvantitativt, men opfatter kompliceret arbejde som mere værdiproduktivt end enkelt arbejde. Empirisk set må merværdiraten være konstant, fordi det er fra sektor II at arbejderens konsumtionsfond hentes, og fordi produktiviteten er nogenlunde ensartet i denne sektor over en vis periode ifølge loven for dannelsen af gennemsnitsraten og produktionspriserne, og det gælder selvom sektor II jo delvis består af landbrugssektoren og selv om produktiviteten kan være lavere der. Thi forholdene er dog ens for resten af samfundet, og for sektor II selv, da kun en forsvindende del af al løn idag betales i naturalier. 
kan kun fuldbyrdes på præmisser, der gør det umuligt, at der faktisk kan realiseres ens profitter af alle kapitaler indenfor en branche. I kapitalens dynamik ligger, at branchekapitaler ${ }^{4} m a ̊$ have forskellig organisk sammensætning og dermed forskellig produktivitet - for ellers ville konkurrencens begreb være ophævet, det forhold altså være ophævet at enhver kapital ifølge sit væsen må søge at maximere sin profit absolut. Loven om dannelse af gennemsnitsprofitraten betyder da, at en kapital med en given sammensætning, altså med en given produktivitet per 100, vil kunne anbringes med samme profit i alle brancher, hvis brancherne betragtes i deres udvikling over en vis periode.

I det følgende skal disse forhold nøje udpensles:

Bestemmende for niveauet for enhedsprisen indenfor cykelbranchen over en vis periode er følgende faktorer:

Virksomhedsantallet i branchen, virksomhedernes størrelse og organiske kapitalsammensætning (produktivitet) og efterspørgslen ${ }^{5}$ på brancheproduktet, disse faktorer bestemmer udbuddets kvalitet og kvantitet.

Lad os for simpelheds skyld fortsat antage, at de 9 firmaer i branchen alle er lige store (100), og at de er inddelt i 3 grupper med hver sin organiske sammensætning, nemlig henholdsvis 9:1, 5:5 og 2:8. Hver virksomhed antages også at producere et forskelligt antal produkter, således at de virksomheder med den største konstante kapitaldel producerer mest.

Hvis vi nu antager at udbud-efterspørgselsmekanismen er i hvile, harmoni, så antager vi også definitorisk, at prisen på cykler vil blive reguleret som et aritmetrisk gennemsnit af totalværdien af cyklerne og af deres antal. ${ }^{6}$ Denne definitoriske antagelse svarer til virkeligheden i den forstand, at udbud-efterspørgselsharmonien selvfølgelig ikke er et statisk begreb - som hvilket det blot illustratorisk af hensyn til tallenes simpelhed fremstilles her - men en tendensstørrelse, udtryk for et realt gennemsnit, der går ud på, at virksomhedsantal og produktivitetsniveauer i alle brancher har en tendens til at blive ensartede p.g.a. kapitalens indog udsivning i brancherne alt efter hvor profitten på en given kapitalsammensætning for tiden er størst. At udbud-efterspørgselsmekanismen harmonerer betyder altså ikke andet end, at nogenlunde de samme afvigelser i retning af højere og lavere organiske sammensætninger hos kapitalerne over en vis periode vil kunne findes mellem alle brancher. I realiteten betyder det altså, at man kan se bort fra udbud-efterspørgselsmekanismen ved konstitueringen af det gennemsnitlige prisniveau i brancherne, og at det her er kapitalernes produktivitetsudvikling, der er primus motor. ${ }^{7}$ Følgende skema kan da opstilles:

4. i.e. kapitaler indenfor samme branche.

5. Efterspørgslen skal i det følgende forblive en uforklaret størrelse indtil den i Del II vil blive belyst $\mathrm{i}$ forbindelse behandlingen af sammenhænge mellem gennemsnitsprofitrate og totalreproduktion.

6. Angående en bestemmelse af begrebet »aritmetrisk gennemsnit« se Nørgård: Nationaløkonomi, Appendix: Elementær praktisk statistik.

7. Se Ole Fogh Kirkeby: Kapitallogik og historie. RUC-forlag og Boghandel, 1975, Del II. 


\begin{tabular}{|l|c|c|c|c|c|c|}
\hline Kapitaler & m' & $m$ & vareantal & $\begin{array}{c}\text { individuel } \\
\text { værdi }\end{array}$ & $\begin{array}{c}\text { enheds- } \\
\text { pris }\end{array}$ & $\begin{array}{c}\text { afvigelse } \\
\text { mellem pris } \\
\text { og værdi }\end{array}$ \\
\hline A: $90 \mathrm{k}+10 \mathrm{v}$ & $100 \%$ & 10 & 10 & 11 & 27,5 & $+16,5$ \\
B: $50 \mathrm{k}+50 \mathrm{v}$ & $100 \%$ & 50 & 5 & 30 & 27,5 & $-2,5$ \\
C: $20 \mathrm{k}+80 \mathrm{v}$ & $100 \%$ & 80 & 1 & 180 & 27,5 & $-152,5$ \\
\hline
\end{tabular}

Enhedsprisen på cyklerne bliver 27,5, hvis vi altså antager, at denne bestemmes af det aritmetriske gennemsnit af totalproduktværdien fra de 3 kapitaltyper og det samlede antal produkter. Ved salget af kapital A, B og C's varer til denne pris vil kapital A realisere en ekstramerværdi på 16,5, kapital B vil miste 2,5 af sin producerede merværdi, og kapital C vil miste 152,5 af sin producerede merværdi.

Ved realiseringen af produkterne, altså gennem deres ophold i cirkulationssfæren, har den producerede værdi gennemgået en forvandling. Denne forvandling, der foregår gennem etableringen af en enhedspris for produktet, korrigerer den individuelle arbejdsmængde, der er blevet anvendt til at fremstille produktet i den enkelte virksomhed og gør værdiproduktion til et totalt fænomen ved at indføre en objektiv norm for den arbejdstidsmasse, der kan anvendes på det enkelte produkt.

I det her behandlede eksempel, hvor udbud-efterspørgselsmekanismen skal harmonere, vil enhedsprisen ligge tæt op af den kapitals produktværdi med den mellemste organiske sammensætning (kapital B), fordi kapital C's enkelte produkt vejer så tungt ud fra sin lave produktivitet, at der skal mange produkter til fra en kapital med høj produktivitet for at opveje det. Og »opvejes« skal det jo, da dette eksempel netop forudsætter at summen af branchepriserne er identiske med summen af brancheværdierne. Enhedsprisen indenfor en branche kalder Marx for »markedsværdien «.

\subsection{Markedsværdiens begrebslige status}

Markedsværdien er et begreb, der er begrænset til prisniveauet indenfor en branche ${ }^{8}$.

Markedsværdien er i vid udstrækning et »realt « begreb, d.v.s. at den kan konstateres direkte i de konkrete prisstørrelser på markedet, omend med visse modifikationer. Disse modifikationer bringer Marx ind, når han skelner mel-

8. Der er vanskeligheder forbundet med det at tale om »markedsværdier«, indenfor en sektor, da markedsværdibegrebet forudsætter et produkt, der er ensartet både hvad angår de stoflige betingelser for dets produktion og de former, hvori det indgår i den produktive eller private konsumtion. Men der er forhold, der taler for at man kan tale om markedsværdi i forbindelse med visse sektorer, f.eks. boligsektoren, sådan som der argumenteres for det i det følgende kapitel om denne sektors problemer. 
lem markedspris og markedsværdi, og her præciseres markedsprisen som de tilfældige afvigelser fra markedsværdien, der kan være i prisbevægelserne, altså som de videnskabeligt uinteressante bestemmelser for værdibevægelsen indenfor en branche. ${ }^{9}$ Markedsværdien viser, at priserne på brancheproduktet er reguleret af værditeoriens lovmæssigheder. Men denne regulering tager en særlig form: markedsværdien er nemlig i det enkelte tilfælde (salg) sjældent dækket værdimæssigt ind.

I det tilfælde vi her har behandlet, hvor udbud-efterspørgselsmekanismen var i hvile, var den totalprismasse som realiseredes gennem markedsværdien dækket ind af totalproduktets værdi i branchen på en dag. Men generelt vil udbud-efterspørgslens harmoni være en tendentiel bevægelse, hvilket betyder, at den prismasse, der realiseres gennem markedsværdierne indenfor en branche i et givet kort interval logisk set ikke behøver at være dækket ind af en værdiproduktion, og generelt sjældent vil være det.

Det sidste skema viser, at markedsværdien 27,5 for kapital A's vedkommende indebærer et salg af produkterne over for deres individuelle værdi, og dermed realiseringen af en merværdimasse, der ligger langt over den producerede merværdi hos denne kapital, nemlig 10 varer à $27,5=270 \div 110=165$. Men af skemaet så vi altså også, at selvom der var tale om en omfordeling af den producerede merværdi, så forblev det omfordelte indenfor denne værdis kvantitative rammer: Totalværdien af produktet $=300+140$ (totalmerværdi $)=$ 440 , mens det realiserede produkt har værdien: $16 \times 27,5=440$.

Gennem realiseringen af brancheproduktet ved udbudsefterspørgselshvile viser det sig, at profitraten for de enkelte kapitalgrupper ændrer karakter fra den, den havde i produktionsprocessen:

\begin{tabular}{|l|c|c|c|c|}
\hline Kapitaler & m' & $m$ & $\begin{array}{c}\text { p'i produktions- } \\
\text { processen }\end{array}$ & $\begin{array}{c}\text { p' i realisations- } \\
\text { processen }\end{array}$ \\
\hline A: $90 \mathrm{k}+10 \mathrm{v}$ & $100 \%$ & 10 & $10 \%$ & $165 \%$ \\
B: $50 \mathrm{k}+50 \mathrm{v}$ & $100 \%$ & 50 & $50 \%$ & $37,5 \%$ \\
C: $20 \mathrm{k}+80 \mathrm{v}$ & $100 \%$ & 80 & $80 \%$ & $-152,5 \%$ \\
\hline
\end{tabular}

Hvis hver enkelt kapitalgruppes hele produktmasse sælges til markedsværdien 27,5, får de altså en helt anderledes profit end de iflg. deres merværdiproduktion skulle.

Af dette følger bl.a.:

Hvis brancheproduktet realiseres til markedsværdien, hvis kapitalerne tænkes med forskellig organisk sammensætning og hvis denne skal komme til udtryk i forskellig produktivitet, altså i forskellig produktmasse, så kan der

9. Se Das Kapital, bd. III, kapitel 10. 
aldrig dannes samme profitrate hos de forskellige kapitalgrupper indenfor en branche.

Indenfor branchen udgør dette forhold kernen $\mathrm{i} \gg$ konkurrencens begreb $\ll$ :

Dennes væsen består i det forhold, at hver kapital søger at erhverve sig så stor en profit som muligt gennem salget af sine varer til de højest tænkelige priser. Kun ydre tvang, af samfundsmæssig eller naturmæssig art, der nivellerer produktivitetsniveauet og indfører ensartet sammensatte kapitaler, kan skabe samme profitrate på alle kapitaler indenfor en branche.

Når markedsværdien ved udbud-efterspørgselsharmoni var 27,5 og denne pris var en pris, der ikke svarede til nogen af de 3 kapitalgruppers individuelle produktværdi, så kan det synes et problem hvordan denne pris opstår.

Den opstår som følge af kapitalistens følen sig frem.

Egentlig kan prisbevægelsen jo kun anskues historisk (diakront), d.v.s. man må her starte med prisbevægelserne set i relation til køretøjets (cyklens) historie indenfor produktions- og konsumtionsprocessen. Men for vores logiske (synkrone) betragtning er brancheproduktets markedsværdi noget altid-allerede-givet, en størrelse, der udvikles som den fremtræder for enkeltkapitalens bevidsthed.

For denne gælder det, at begrebet merværdi ikke eksisterer. Man kan højst sige at begrebet »relativ merværdi « kan have en vis fænomenologisk status som det vage forhold mellem kapitalistklasse og arbejderklasse udtrykt i forholdet mellem bevægelser i lønniveauet og salgsprisen for brancheproduktet.

Enkeltkapitalen kender kun begrebet omkostningspris og så begrebet profit, og sætter ikke de to systematisk i relation til hinanden gennem begrebet merværdi. Sådan en forbindelse er en ideel, abstrakt konstrueret forbindelse, der hører hjemme på niveauet-for-kapital-i-almenhed og ikke kan anvendes til at forklare konkurrencens fænomener.

Kapitalisten ved altså simpelthen ikke hvad den individuelle værdi af hans produkt er, og derfor sætter markedsværdien sig igennem i enhedsprisen for produktet ved at udtrykke sig i kapitalstens anelser og fornemmelser af hvad han kan tage for sin vare, d.v.s. hvor meget over omkostningsprisen han kan sætte sin pris uden at få noget restlager. Dermed vil hans handlinger altid være bestemte af hans relation til andre kapitalister, altså til de mere og mindre produktive kapitaler, således at markedsværdiniveauet er udtryk for en prisfastsættelse, der er resultatet af et permanent spændingsforhold ${ }^{10}$.

Hvis vi nu forlader antagelsen af en harmoni i udbud-efterspørgslen på cykler og f.eks. antager, at efterspørgslen i udtalt grad overstiger udbuddet, så vil - hvis stigningsgraden er tilstrækkelig stor -markedsprisen kunne blive identisk med kapital C's individuelle produktværdi, altså ligge på 180.

10. Jeg er her bort fra prisaftaler, der dog i vid udstrækning kan afledes af den rene konkurrences begreb. 
De 16 cykler, der laves i branchen på en dag vil da kunne sælges til totalværdien 2880, altså 2440 over den værdi de har når de kommer ud af produktionsprocessen.

Kapital A og B vil da kunne realisere enorme ekstraprofitter, nemlig henholdsvis: 1690 og 750.

Hvis derimod efterspørgslen på cykler falder drastisk, så vil det måske ende med at kapital A's individuelle produktværdi regulerer markedsprisen, og så vil kapital $\mathrm{B}$ og $\mathrm{C}$ ikke alene sætte deres producerede merværdi til, men også blive blokeret i reproduktionen af deres kapital.

I første tilfælde vil der være realiseret meget mere værdi indenfor branchen end der er produceret i den. Marx kalder denne ekstra-realiserede værdimasse for »falsk social værdi «. Vi vender tilbage til dette begreb i næste afsnit.

Men enkeltkapitalistens fornemmelser for hvad han kan tage for sin cykel er mere end en fingerspitzgefühl. Han har nemlig profitterne i de andre brancher til at assistere sig ved programmeringen af sit profitniveau. (Hvad enten han nu snakker med sine kolleger i de andre brancher, studerer aktiemarkedet, prisudvikling, ect.) Hvis han nu synes, at hans kapital per 100 burde give mere profit i forhold til sin sammensætning - fordi dette er tilfældet i nogle andre brancher - og han p.g.a. udbuddets størrelse og efterspørgslens faldende tendens ikke kan sætte sine priser op, så kan han flytte sin kapital til en anden branche, hvor en kapital per 100 med samme sammensætning giver større profit, eller han kan ændre sin egen kapitals sammensætning i retning af en forøgelse af k-delen med henblik på yderligere produktivitet.

Omvendt vil kapitaler fra de andre brancher gennem salg af deres maskiner og bygninger eller via lånemarkedet sive ind i cykelbranchen hvis profitbetingelserne er særlige gunstige der: hvis f.eks. markedsværdiniveauet er så højt at man med en relativt lille kapital eller en relativt lav sammensætning kan opnå ekstraprofitter. Naturligvis vil virkningen af en sådan indsivning være, at markedsværdiniveauet falder, fordi udbuddet stiger, og således nivelleres ekstraprofitniveauet atter.

Resultatet af denne ind- og udsivningsproces er, at der tendentielt indenfor brancherne vil være samme profitniveau ved samme kapitalsammensætning - de stoflige forskelle undtaget. Men dette er faktisk udtryk for en tendens, og på et givet tidspunkt vil en given sammensætning indenfor en given branche kunne give meget store ekstraprofitter. Pointen er bare, at dette forhold ikke kan være permanent.

\subsection{Produktionspris-begrebet}

Gennem denne ud- og indvandring af kapital - der selvfølgelig er afhængig af mulighederne for at frigøre kapital, låne kapital og for at kunne omsætte denne kapital i pengeform til produktionsmidler - vil der i alle brancher dannes et gennemsnitligt profitniveau - siger Marx. 
Hvor vi slog fast, at branchen iflg. konkurrencens begreb vil være kendetegnet af det forhold, at der vil være forskellige profitter, så er samfundet som helhed kendetegnet ved det forhold, at der mellem brancherne vil være tendens til at dannes et ensartet profitniveau, men dette profitniveau foreligger aldrig som en statisk størrelse, som noget permanent:

Derfor kan Marx betegne gennemsnitsprofitraten som »et sløret tågebillede« (Das Kapital, bd. III, s. 381), sige, at den fremtræder alene som »profittens minimalgrænse, ikke som empirisk, direkte synligt udtryk for den virkelige profitrate«. (ibd. s. 380).

For hvis gennemsnitsprofitraten skulle være statisk, noget ikke fluktuerende, engang-for-alle etableret, så skulle der herske samme markedsværdiniveau og samme produktivitetshierarki indenfor hver branche: samme antal firmaer fordelt på kapitalgrupper med samme organiske sammensætning.

Men dette er en tilstand, som medføres af kapitalerne i deres bevægelse mod den uendelige profitmaksimering, dog det er kun en tendens, et ideelt gennemsnit, det kan aldrig blive en tilstand - især fordi det indebærer at alle produktionsprocesser har samme stoflige betingelser for organisk kapitalsammensætning.

»Derimod kan profitraten (Marx sammenligner profitraten med den almene rentefod) selv indenfor den samme branche ved ens markedspriser være forskellig, alt afhængig af de forskellige betingelser, hvorunder de enkelte kapitaler producerer den samme vare; thi profitraten hos enkeltkapitalen bestemmes ikke gennem varens markedspris, men gennem forskellen mellem markedspris og omkostningspris. Og disse forskellige profitrater, først indenfor den samme branche og så mellem de forskellige brancher, kan kun udlignes gennem bestandige svingninger«. (Das Kapital, bd. III, s. 381-382. Min overs. OFK)

Hvis man alligevel vil opfatte gennemsnitsprofitraten som en real størrelse af en eller anden art - og det gør Marx faktisk i sammenhæng med det ovenfor citerede, ved at sige, at »Den almene profitrate fremtræder derfor faktisk som empirisk, givet faktum i den gennemsnitlige rentefod, selvom den sidste ikke er et rent eller tilforladeligt udtryk for den første« (Das Kapital, bd. III, s. 377-378), - så kan det kun lade sig gøre ved at man udgår fra det forhold, at et givet brancheprodukt generelt produceres ved en herskende produktionsteknik - hvorfra der så er bedre og dårligere afvigelser - hvad angår kapitalsammensætning - og derfor vil profitniveauet $i$ en række brancher reguleres af de virksomheder der - $i$ kraft af deres antal og sammenhæng med den almindelige udvikling af teknikken - ligger på dette typiske produktivitetsniveau. Men her er der nok alligevel så mange afvigelser fra reglen, at Marx's sammenligning mellem rentefod og gennemsnitsprofitrate er en mere holdbar tese, fordi den jo faktisk næsten indskrænker sig til at sige, at rentefoden bestemmes af forholdet mellem totalkapital og totalmerværdi.

Konklusionen her må da være, at der på et givet tidspunkt vil kunne konstateres ret forskellige profitrater i de forskellige brancher i samfundet alt efter udbud-efterspørgslens karakter og efter de stoflige betingelser for produktionen, men denne tilstand kan ikke være langvarig i betydningen: de brancher hvis profit 
lå under gennemsnittet vil forøge deres profit ved at udbuddet gennem kapitaludvandring falder, og de kapitaler, der lå over profitniveauet vil miste noget profit gennem udbuddets forøgelse, fordi der siver kapitaler til. Her må man dog sige: hvad er det for et profitniveau, man taler om at profitten ligger »over« eller »under «, og hvis svaret ikke skal være rent historisk, altså angå relative prisbevægelser, så er det absolutte prisniveau naturligvis det, der bestemmes af den profitmasse som branchen - ifølge den del dens totalkapital udgør af den samfundsmæssige totalkapital - burde have. Og den kan naturligvis bestemmes ud fra forholdet mellem produceret værdi i branchen og produceret værdi i samfundet som helhed.

Pointen er altså, at de priser, der gør gennemsnitsprofitraten mulig ikke er priser, der kan konstateres gennem et snit på tværs af tiden, men er afhængig af den tidsmæssige udfoldelse: gennem kapitalbevægelserne indenfor og mellem brancherne er der tendens til at ens sammensatte kapitaler vil kunne anbringes med nogenlunde samme profit i alle brancher, hvilket er det samme som at sige at ligestore kapitaler med forskellig sammensætning vil tendere mod at give samme profit indenfor brancherne. Paradokset, der tilsyneladende ligger heri er kun tilsyneladende, for det sagte betyder blot: i en given branche vil konkurrencen bevæge sig således fremad, at de lavt sammensatte kapitaler vil afskaste mindre profit end den merværdi de ved konstant merværdirate ifølge deres variable kapitals størrelse giver, og de kapitaler, der er højt sammensat vil tilegne sig mere profit end den merværdi de faktisk producerer.

Det betyder, at alle brancher logisk set på et eller andet tidspunkt må befinde sig i en sådan situation, at højt sammensatte kapitaler giver ekstraprofitter, men det betyder ikke at alle brancher på samme tidspunkt giver præcis samme profit til samme kapitalsammensætning.

De priser, der gør det muligt, at alle kapitaler gennem deres interaktion tenderer mod at sælge til priser, der gør realiseringen af en gennemsnitsprofit mulig, kalder Marx for, at der dannes produktionspriser mellem brancherne.

Sætter en kapitalist en kapital med en given kapitalsammensætning per 100 ind i en branche på et givet tidspunkt, så vil den profit som denne kapital giver være afhængig af markedsværdiniveauet på det givne tidspunkt, altså være afhængig af antallet af virksomheder, deres produktivitet og endelig af udbud efterspørgsels-mekanismens tilstand. Placeringen af kapital i denne branche kan altså på et givet tidspunkt give langt mere end placeringen af præcis den samme mængde og ens sammensatte kapital i en anden branche. Men i selve placerings-processen ligger den virkning indbygget, der gør at lige store kapitaler vil afkaste samme profitter over en vis periode: thi kapital-placeringen i branchen vil ændre udbuddets karakter, den relative produktivitet, etc.

Hermed er ment det forhold, at to kapitaler gennem direkte handel med hinanden - såfremt disse kapitaler tilhører hver sin branche med hver sit markedsværdiniveau - i deres bytteakt vil opføre sig således, at den kapital, hvis produktivitet ligger langt over gennemsnittet og hvis markedsværdiniveau ligger langt under 
markedsværdiniveauet i det $\emptyset$ vrige samfund, vil realisere sine varer til en værdi, der ligger langt over den individuelle værdi af produktet. Gennem udvekslingen af to brancheprodukter - v.hj. af den almene ækvivalent - vil der altså ske en »værdioverførsel «.

Men denne værdioverførsel har alligevel i vid udstrækning karakter af et forhold, der sætter sig igennem som en tendens. Værdioverførsel betyder slet og ret, at en branche p.g.a. sin højproduktive kapital kan sælge produktet over dets individuelle værdi, fordi der er et samfundsmæssigt behov for det, og fordi produktivitetsniveauet i de andre brancher har så ensartet en karakter, at det lægger en norm for et gennemsnitligt kapitalafkast.

»Værdioverførsel« skal altså ikke forstås som et begreb for en sindrig form for værdi-udvekslingsmekanisme i en bytteakt mellem to sektorer, men ud fra forholdet mellem en branche og totalmassen af arbejde i samfundet: værdioverførsel betyder, at der anvendes mere arbejde i en række brancher end der ud fra et samfundsmæssigt rationelt synspunkt burde. Det gør, at de brancher, hvori det menneskelige arbejde anvendes med optimal rationalitet, d.v.s. hvor det er mest produktivt, at disse brancher er atypiske i forhold til niveauet for det samfundsmæssigt nødvendige arbejde i de andre brancher, og derfor kan realisere en profit, der svarer til en lavere akkumulationsgrad ${ }^{11}$.

Kernen i Marx's begreb for produktionsprisen går ud på, at de virkelige ekstraprofitter realiseret indenfor brancherne altid udspringer af branchens relation til udviklingen af det menneskelige arbejde i de andre brancher: enten udspringer ekstraprofitterne af det forhold, at branchens produktivitet ligger under eller over gennemsnittet i samfundet eller af det forhold, at den kapital, der realiserer ekstraprofitten har en meget høj sammensætning - et forhold der mere er specifikt for kapitalen selv end for branchen. Forudsætningen for ekstraprofitterne er det forhold, at værdi og produktionspris principielt ikke falder sammen.

»Produktionsprisen og den almene profitrates eksistens og begreb, beror på det forhold, at de enkelte varer ikke sælges til deres værdi. Produktionspriserne udspringer af en udligning af varerværdierne, der - efter at de kapitalværdier, der er blevet opbrugt i de forskellige branchers (produktionsproces) er blevet reproduceret - fordeler den totale merværdi, ikke i den proportion hvori den er blevet produceret indenfor de enkelte brancher, og derfor er produkterne iboende, men i proportion med de fremskudte kapitalers størrelse. Kun således opstår en gennemsnitsprofit og en produktionspris for varerne, hvis karakteristiske element den er«. (Das Kapital, bd. III, s. 769. Min overs. OFK.)

Det er altså afgørende for gennemsnitsprofitratens og produktionsprisens begrebslige status, at de er tendensbegreber, ikke fast afgrænselige størrelser, men at de er afhængige af en udfoldelse i tiden, af en cyklus for at udfolde deres væsen.

Begrebet produktionspris betyder da simpelthen, at ved et givet produktivitetsniveau indenfor en branche vil en kapital med en lavere sammensætning

11. Jeg refererer her til den marxske akkumulationsteoris nøgletese: at den organiske kapitalsammensætning vil stige og profitraten derfor falde indenfor hver cyklus og formodentlig også på tværs af cykluserne. 
kunne realisere hele sin producerede merværdi. Men som branchens historie udvikles gennem en tilsivning af kapitaler og dermed den forøgelse af udbuddet, der ved at skærpe konkurrencen fjerner de mest lavproduktive kapitaler, så sænkes markedsværdiniveauet og dermed muligheden for realiseringen af hele den producerede merværdi for den omtalte kapital. Denne kapital har altså ved en given sammensætning og ved konstant merværdirate gennemgået en personlig livshistorie, hvori den startede med en høj profitrate - hvor profitten svarede til den producerede merværdi - og hvori den endte med knap at kunne realisere sin fremskudte kapital.

Samtidig er en række andre kapitaler opstået, med højere sammensætning, der realiserer ekstramerværdi mens markedsværdien endnu ikke er sunket så drastisk, d.v.s. mens branchen endnu ikke er blevet helt oversvømmet af kapital.

Denne udvikling passer til en branche med en traditionel lang historie, tekstilbranchen f.eks. Og pointen er at parallelt med det synkende markedsværdiniveau går dannelsen af den gennemsnitlige profit som de enkelte kapitaler $\mathrm{i}$ løbet af deres historie realiserer.

Men en anden type branchehistorie har de brancher, der er opstået med ny videnskab og teknik: brancher hvori der produceres elektronisk udstyr f.eks. Disse brancher er stofligt betingede for en meget høj kapitalsammensætning og indenfor disse vil markedsværdien - også selvom den reguleres af den lavest produktive kapital i branchen - ligge langt under niveauet i resten af samfundet. I denne branches livshistorie vil der kunne realiseres ekstraprofitter i forhold til den producerede profit (=merværdi), men her betragter vi forholdet mellem brancherne. Ekstraprofitten er altså her reguleret af det forhold, at den producerede profit er for lille til at give den profit som branchens kapitaler i forhold til kapitaler med samme sammensætning giver i andre brancher. Brancheproduktet vil altså her - for at salget kan give gennemsnitsprofitten - blive solgt til produktionspriser, der ligger langt over markedsværdiniveauet.

I næste afsnit skal vi præcisere ekstraprofittens 3 kilder, men her skal det principielle forhold belyses at hvor forskelle mellem profitterne på forskellige kapitaler indenfor en branche er hele konkurrencens dynamiske væsen, så gælder det, at kapitalbevægelsernes egen dynamik går i retning af at nivellere ekstraprofitter, der består på grundlag af produktivitetsforskelle mellem brancherne.

»Det er kapitalernes stadige tendens at bevirke udligningen i fordelingen af den af totalkapitalen producerede merværdi gennem konkurrencen og at overvinde alle hindringer for denne udligning. Det er derfor deres tendens kun at tolerere sådanne ekstraprofitter, som under alle omstandigheder, ikke p.g.a. forskellen mellem varernes vardier og produktionspriser, udspringer af den almene markedsregulerende produktionspris og de fra denne afvigende individuelle produktionspriser; (min fremhævelse, OFK.) (Marx taler her om det umulige i en profit indenfor industrisektoren, der som jordrenten ved »den absolutte jordrente « udspringer af en permanent lavere produktivitet indenfor landbrugssektoren, altså udspringer af det forhold, at markedsværdien indenfor landbrugssektoren permanent ligger over det produktionsniveau som konstituteres i industrisektoren. OFK.) ekstraprofitter, der derfor heller 
ikke finder sted mellem to forskellige brancher, men indenfor hver branche, og derfor ikke berører de almene produktionspriser mellem de forskellige brancher, altså ikke berører den almene profitrate og i stedet forudsætter forvandlingen af værdier til produktionspriser og den almene profitrate. Denne forudsætning beror dog, som tidligere belyst, på den stadige skiftende proportionelle fordeling af den samfundsmæssige totalkapital mellem de forskellige brancher, på stadig kapitaltil- og fragang, på deres (kapitalernes) overførbarhed fra en branche til en anden, kort og godt på den frie bevægelse mellem de forskellige brancher i egenskab af ligeså mange anlægssteder for den samfundsmæssige totalkapitals enkelte dele.« (Min overs. OFK. Das Kapital, bd. III, s. 769-770).

Skal det give mening, at ekstraprofitterne forudsatter dannelsen af produktionspriser, så refererer det til indførelsen af ens »produktionskoefficienter « $\mathrm{i}$ brancherne.

Denne proces er naturligvis begrænset af de stoflige muligheder for en ensartet produktionsproces, men hvor disse er nogenlunde givet betyder dannelsen af ens »produktionskoefficienter«, at forholdet mellem maskiner og arbejdere vil finde et generelt niveau bestemt af den herskende teknik og af arbejdskraftens uddannelsesgrad.

Teknikken betyder: bevægelses-, transmissions- og arbejdsmaskiner, hvor i alt fald bevægelsesmaskinerne i vid udstrækning udtrykker en normaliseret teknik: damp, diesel etc. Det betyder altså, at hver branche har en faktisk, real gennemsnitsproduktivitet bestemt af en mellemstor kapitalmasse ved en given organisk sammensætning. »Fast produktionskoefficient « betyder da,at man for at ændre den organiske sammensætning (denne indikerer direkte teknisk sammensætning, altså produktivitet) skal bevæge sig over i en helt anden »kapitalklasse«. Man kan altså ikke bare ansætte to ekstra arbejdere - for det kræver en ændring af hele maskinparken, og man kan ikke investere 100.000 til i maskiner, fordi en forøgelse af produktiviteten kræver et helt nyt system af arbejdsmaskiner. ${ }^{12}$

Det betyder også - det Marx her siger i citatet - at udbudefterspørgselsmekanismen vil være den samme for alle brancher over en cyklus, med forskellige udsving - naturligvis - på forskellige tidspunkter. De faste produktionskoefficienter og udbud-efterspørgsels-harmonien indebærer, at både repræsentationen af kapitalgrupper (inddelt efter organisk sammensætning) og deres antal vil være relativt ens i alle brancher over en cyklus - med den nedre og фvre grænse for kapitalanlæg som produktionsprocessens stoflige særegenheder sætter.

I cyklusens $l ø b$ vil ekstraprofitterne og minusprofitterne $\mathrm{i}$ alle brancher altså tenderer mod at blive ensartede i den forstand at ingen branche i meget længere tid end de andre kan tilegne sig ekstraprofitter ved at have et højere markedsværdiniveau eller en større produktivitet end gennemsnittet.

Denne udligningsproces vil så - alt efter som produktivkræfterne udvikles i løbet af kapitalismen - gentage sig på højere og højere produktivitetsniveauer.

12. Se Jon Elster, der roder differentialrenterne sammen i sin underlige på engang formalistisk udskejende og sikkert problematiserende bog: Om Kapitalen, en introduktion til Marx' hovedværk, Oslo 1969, s. 71. Begrebet »produktionskoefficient« introduceres s. 69. 
Det her sagte betyder kun, at totalmerværdien bestemmer totalprofittens grænser over en cyklus, og at totalprissummen er reguleret af totalværdimassen.

Det betyder ikke at totalværdien produceret indenfor en branche i løbet af en cyklus med nødvendighed afgrænser den dér mulige prismasse og profitmasse. Men når Marx taler om dannelsen af produktionspriser, så mener han, at en branche, der p.g.a. sin overgennemsnitligt produktive kapital kan realisere ekstraprofitter mellem brancherne, at dens profitniveau vil nivelleres p.g.a. fald i efterspørgslen eller p.g.a. at resten af brancherne kommer op på samme produktivitetsniveau. Det betyder selvfølgelig ikke at der i denne branche - fordi der har været store ekstraprofitter - nu også må skabes et væld af minusprofitter, for at regnskabet skal stå lige. Det betyder bare at ekstraprofitterne ikke kan blive ved i det uendelige.

Skal vi anvende begreberne gennemsnitsprofitrate og produktionspris til at angive konkretere værdibevægelser, så hører følgende overvejelser med:

\subsection{Produktionspris, gennemsnitsprofitrate og markedsværdi som indi- katorer for værdibevægelser på det konkrete plan}

Den logiske eller metodologiske forudsætning for at tænke produktionsprisog gennemsnitsprofitrate-begreberne er dels begrebet »værdiproduktion«, dels markedsværdibegrebet: produktionspriserne og gennemsnitsprofitraten bliver mulige, alene fordi varerne kan realiseres til en anden værdi end den, der fremgår af den tid, der anvendtes ved deres produktion.

Omvendt er produktionsprisen den historiske betingelse for markedsværdiniveauet indenfor den enkelte branche. For det første er produktionspriserne princippet for kapitalbevægelserne mellem brancherne, for det andet er produktionspriserne i en række brancher vejledende for salgsprisen for kapitaler indenfor brancher hvis markedsværdier ligger under andre branchers eller for brancher, hvis individuelle værdier ligger langt over de andre branchers. Tager vi for eksempel en branche med en meget høj kapitalsammensætning, p.g.a. produktionsprocessens stoflige karakter, hertil en meget høj grænse for kapitalanlæg - altså alt i alt en meget produktiv branche - lad os sige det er en branche hvori der produceres måleapparater til overlydsfly, så vil markedsværdiniveauet her ligge meget lavt, da merværdimassen ved konstant m' p.g.a. den relativt lille variable kapital vil være meget lille ${ }^{13}$. Det ændres heller ikke af det forhold, at efterspørgslen voldsomt overgår udbuddet - i alt fald ikke hvis vi antager, at markedsværdiniveauet i branchen ikke kan komme op over den grænse som den individuelle værdi af den mindst produktive kapital sætter.

13. Das Kapital, bd. III, s. 767. 
Jeg vil her lige gentage, at hvor markedsværdien udgør et prisniveau indenfor en branche, der er dækket ind af den faktiske værdiproduktion i branchen, så ligger det i produktionsprisens væsen, at den afviger fra markedsværdierne.

De grænser, der er sat for markedsværdien - at den altså hvis den i længere tid skal konstitueres af den mindst produktive kapital, i en anden periode af cyklusen må presses så meget ned at værdiunderskuddet opvejes, hvilket er en naturlig følge af den kapitaloverflod i branchen som et højt markedsværdiniveau skaber - gælder ikke for produktionsprisen: i den omtalte branche vil salgsprisen ligge over markedsværdien - der repræsenterer den højeste individuelle værdi og den vil ligge så meget over, at gennemsnitsprofitten danner bundgrænsen for salgsprisen. Denne konstitueres altså af varens produktionspris.

Det kan være problematisk at hæfte så konkret et indhold på et så tendensbestemt og »agerende « begreb som produktionsprisen, men det er rimeligt at gøre det i netop denne forbindelse, samt i een til, som vi skal se i det følgende.

Produktionsprisens »realitet « viser sig her i det forhold, at det er den, som kapitalerne lægger deres prisniveau efter indenfor sådanne højproduktive brancher, det er nemlig den, der fortæller dem, hvad de kan vente sig af et givet kapitalanlæg, dvs. hvor stor en profit de kan lægge oveni omkostningsprisen, og hvor store negative udsving de kan bære over med i deres profitrate uden at flytte deres kapital. Hvis produktionsprisen her skal konkretiseres - og med den gennemsnitsprofitraten - stiller det et logisk problem: hvilke brancher er de oprindelige produktionsprisangivende?

Historisk set løser problemet sig selv ved at visse brancher har været de første for kapitalanlæg og har været meget profitable, brancher som tekstil, jernbaner ect., men logisk set er problemet tilbage.

P. Sraffa berører problemet i sin indledning til udgaven af Ricardos samlede skrifter, når han siger, at Ricardos indledende berøring med værdibegrebet udgik fra den tese, at »it is the profit of the farmer, that regulate the profits of all other trades $\ll .^{14}$

Ifølge Sraffa skyldes denne tese et argument, der kan rekonstrueres, og som går ud på, at det i landbrugssektoren er den samme vare, der fungerer som kapitalen og produktet, dvs. at profitten kan bestemmes udelukkende i brugsværditermer når den reproduktive kornmasse trækkes fra produktet. I alle andre brancher indgår andre produkter i kapitalen og der findes derfor ikke noget »naturgivent « profitniveau.

Men det er klart, at for Marx - der inddrager landbrugssektoren som en integreret del af den kapitalistiske $\varnothing$ konomi - kan profitniveauet i landbrugssektoren ikke blot ikke sættes logisk $f \phi r$ profitniveauet i industrien, men er selv konstitueret af dette via betingelserne for dannelsen af »den absolutte jordrente«. (se

14. Sraffas indledning til The Works and Correspondence of David Ricardo, Cambridge 1970, bd. 1 . 
fremme). For Marx vil en sådan abstraktion forblive historieløs tilsnigelse, der ikke begriber, at betingelsen for produktionen er kapitalens bevægelser.

Forskellen mellem brancheproduktets individuelle værdi, den værdi, der optimalt kan realiseres gennem den $\mathrm{i}$ branchen producerede værdi og så produktionsprisen (eller en pris der ligger derover) kalder Marx for ekstraprofitten. I modsætning til ekstramerværdien, der alene kan realiseres indenfor en branche hører ekstraprofitten til i forholdet mellem brancherne.

Vi støder her igen på begrebernes dobbelte karakter her på niveauet-forkapitalen-i-dens-realitet: de er både begreber, der kun udtrykker en tendens, resultatet i gennemsnit af kapitalers livsforløb, og de er begreber, der i visse situationer, kan antyde en sammenhæng, der udgør et snit gennem tiden:

Tendensmæssigt gælder følgende: markedsværdien må som resultat af prisbevægelserne indenfor en cyklus i almindelighed være forløbet indenfor de rammer som den producerede totalværdi i branchen sætter. Markedsværdien er her et grænsebegreb, der angiver hvor meget profit arbejdet ifølge sin absolutte produktivitet kan høste, mens ekstraprofitten angiver hvor meget det ifølge sin relative produktivitet har fået. Produktionsprisen gør realiseringen af den relative produktivitets frugter mulige. Ekstraprofitten er her et begreb, der angiver, at branchen ifølge sin produktivitet adskiller sig fra samfundets gennemsnitsbetingelser, men ifølge sine kapitalers væsen præcis lever op til disse gennemsnitsbetingelser: at afkaste en given profitrate. Generelt må kapitalernes bevægelse mellem brancherne dog medføre, at kapitalerne i den branche, der i begyndelsen realiserer enorme ekstraprofitter ved at varerne sælges over produktionsprisen, langsomt - gennem kapitaltilsivning - ser prisniveauet synke, først til produktionsprisniveau, så til et markedsværdiniveau, der sættes af den mindst produktive kapital og endelig til markedsværdiniveau, der måske sættes af de mest produktive kapitaler, hvilket betyder produktion med tab for resten af branchen.

Ekstraprofitten er altså ikke et permanent fænomen, men vil ifølge kapitalens og dermed konkurrencens væsen udlignes. I et givet udsnit i tiden af forholdet mellem brancherne vil ekstraprofitten gennem sin eksistens belyse den anarkiske fordeling af teknik og videnskab i produktionen, belyse kapitalismens irrationalitet med henblik på en output-effektiv organisering af produktionen, og belyse visse branchers rolle (politiske) og situationen i total reproduktionen, belyse udbud-efterspørgslens forløb, og belyse arbejderklassens underkastelse under kapitalens behov.

Der er 3 fundamentale former for ekstraprofit, der hver især har et forskelligt forhold til værditeorien:

I) Den kan som i dette eksempel være forskellen mellem den producerede gennemsnitligt alt for lave - profit i en højproduktiv branche og så den profit, der ved salg til produktionsprisen svarer til gennemsnitsprofitraten eller ved salg til en højere pris til en profit, der ligger derover. I dette tilfælde er 
markedsværdien ikke nogen real størrelse, men så at sige brancheproduktets individuelle værdi.

II) Ekstraprofitten kan være forskellen mellem produktionsprisen i f.eks. industrisektoren og så produktværdien i landbrugssektoren, hvor den sidste p.g.a. lavere organisk sammensætning ligger over produktionsprisen i industrisektoren, og p.g.a. efterspørgslens pres sammen med monopolet på jord og skrankerne for kapitaltilførsel kan sælges til en højere værdi end produkterne $\mathrm{i}$ industrien.

Denne ekstraprofit, der altså udspringer af landbrugets manglende produktivitet, og som er den rest, der er tilbage, når landbrugsproduktets omkostningspris + gennemsnitsprofitten er trukket fra, kalder Marx for »den absolutte jordrente «.

III) Endelig kan ekstraprofitten bestå af den ekstra værdimasse, der realiseres, hvis produktiviteten indenfor en branche er så lav at efterspørgslen overstiger udbuddet permanent og intenst, således at den mindst produktive kapitals produktværdi regulerer markedsværdien.

Dette tilfælde er det Marx forstår ved den systematiske årsag til differentialrenterne indenfor landbrugssektoren. (Das Kapital, bd. III, s. 654).

Det sidste tilfælde betegner Marx alene som et tilfælde, hvori der »skabes« »falsk social værdi «. Marx viser s. 673, i bd. III af Das Kapital, hvordan der gennem differentialrenterne kan realiseres en næsten 3 gange så stor værdi som der skabes indenfor sektoren, og siger så:

»Dette er bestemmelsen gennem markedsværdien, således som den på basis af den kapitalistiske produktionsmåde sætter sig igennem via konkurrencen; denne skaber en falsk social værdi«. (Min overs. OFK.)

I de to første tilfælde er der naturligvis også tale om skabelse af en form for $»$ falsk social værdi $\ll$.

Kernen i dette begreb består altså i, at der indenfor en branche enten realiseres mere værdi end der skabes over et givet forløb (cyklus), tilfælde I og III, eller produceres og realiseres mere værdi end der burde, hvis branchen gennem sin cyklus faktisk integreredes i dannelsen af produktionspriserne og gennemsnitsprofitraten.

Perspektivet $\mathrm{i}$ brugen af begrebet »falsk social værdi« ligger bl.a. i en påvisning af, hvordan kapitalismen spilder det samfundsmæssige arbejde sammenlignet med hvordan en socialistisk organisering af produktionen ville fordele arbejdet. Dette perspektiv følger eksplicit i passagen, der kommer umiddelbart efter at Marx har defineret begrebet »falsk social værdi«. Fortsætter vi ovennævnte citat hedder det:

»Denne (»den falske sociale værdi«, OFK.) udspringer af markedsværdiens lovmæssighed, som agerbrugsprodukterne er underkastet. Bestemmelsen af produkternes markedsværdi, altså også af agerbrugsprodukternes, er en samfundsmæssig proces, selvom det er en samfundsmæssig ubevidst og ikke-intenderet fuldført (handling, OFK.), der med nødvendighed er betinget af bytteværdien hos produktet, ikke af jorden og forskellene i dennes frugtbarhed. Tænker man sig den kapitalistiske form for samfund opløst og samfundet organiseret som bevidst og planmæssig samvirken, så ville de 10 quarters udtrykke et kvantum selvstændig arbejdstid, lig det, der er indeholdt i de 240 
shilling, (i stedet solgtes produktet til 600 shilling, dvs. der var i kapitalismen indeholdt 360 shilling »falsk social værdi« i det. OFK.) Samfundet ville altså ikke købe dette agerbrugsprodukt for $21 \frac{1}{2}$ gange så meget som den virkelige arbejdstid, der er udgivet på det; jordejerklassen ville da falde væk som basis (for produktionen. OFK.) Dette ville virke præcis lige sådan som en billiggørelse af produktet med samme beløb p.g.a. import. Så sandt som det er at sige, at såfremt produktionsmåden ikke forandres, men det forudsættes, at differentialrenten tilfalder staten - agerbrugsprodukternes priser ved ellers uforandrede omstændigheder ville forblive de samme, lige så forkert er det at sige, at produkternes værdi ville forblive den samme, hvis den kapitalistiske produktion afløstes af producenternes frie samvirke. Ensartetheden hos markedsprisen på varer af samme art er den måde, hvorpå vardiens samfundsmassige karakter satter sig igennem på basis af den kapitalistiske produktion og overhovedet på basis af en produktion, der hviler på varebytte mellem enkeltpersoner. Hvad samfundet som konsument betragtet betaler for meget for agerbrugsprodukterne, hvad der udgør et minus for realiseringen af dets arbejdstid i agerbrugsprodukter, udgør nu et plus for en del af samfundet, for jordbesidderne«. (Das Kapital, bd. III, s. 674. Min overs. og fremhævelse. OFK.)

»Den falske sociale værdi « er altså et produkt af det forhold, at kapitalen af al magt vil maximere sin profit, og af at visse sociale forhold - eksistensen af monopol på jord og befolkningseksplosionen - gør et permanent højt markedsværdiniveau nødvendigt og muligt.

Marx's begreb »absolut jordrente« - der udvikles i polemik mod Ricardos jordrentebegreb - går ud på, at monopolet på jord skaber institutionelle betingelser for en blokering af udbuddet af landbrugsprodukter, nemlig ved at blokere inddragelsen af mindre frugtbare jorde til kornavl. Blokeringen foregår, fordi jordene kun kan dyrkes, hvis der betales en leje for dem, og denne leje er netop jordrenten. Følgelig vil der kun blive anlagt kapitaler på de jorde, der ved salget af deres produkter giver både jordrenten og en profit svarende til, hvad man ville kunne få ved anlæg af samme kapital i industrisektoren. Kun jorde inddrages altså, der gør et så lavt omkostningsniveau muligt, at både gennemsnitsprofit og jordrente kan realiseres gennem salget af produktet.

Det ligger i kapitalens væsen, at den kun tolererer ekstraprofitter indenfor brancherne, ikke mellem dem, dvs. at hele konkurrencens bevægelse går mod en reduktion af de mellem-branchemæssige ekstraprofitter, som naturligvis hele tiden realiseres. Derfor vil kapitalen sive til den branche, hvor ekstraprofitterne i forhold til resten af samfundet et størst (de stofligt bestemte kapitalanlægsgrænser spiller naturligvis ind her), eller hvor der realiseres en gennemsnitsprofit ved lavere sammensætning end i resten af samfundet (disse to tilfælde er naturligvis helt forskellige).

Kun hvor denne kapitalbevægelse ikke er institutionelt mulig - som i landbruget i England på Marx’s tid og især før ophævelsen af The Corn Laws - vil de høje markedsværdier og dermed ekstraprofitterne kunne være permanente.

Dannelsen af produktionspriser og gennemsnitsprofitrate er helt afhængig af udeblivelsen af sådanne institutionelle skranker:

»Det er her forudsat at ingen eller højst en kortvarig eller tilfældig skranke forhindrer kapitalernes konkurrence - f.eks. i en branche, hvor vareværdierne står over deres produktionspris eller hvor den producerede merværdi ligger over gennemsnitsprofitten - i at reducere værdien til produkti- 
onsprisen og dermed fordele den overskydende merværdi fra denne branche proportionelt mellem alle de brancher, som kapitalen har udbyttet. Hænder derimod det modsatte, støder kapitalen på en fremmed magt som den kun delvis eller slet ikke kan overvinde, og som begrænser dens anlæg indenfor visse brancher, altså kun tillader dem under betingelser, der udelukker den almene udligning af merværdien til gennemsnitsprofit helt eller delvis, så ville der åbenbart opstå en ekstraprofit i sådanne brancher p.g.a. den overskydende rest hos vareværdien over dens produktionspris, der ville blive forvandlet til rente således selvstændiggjort overfor profitten. Som en sådan fremmed magt og skranke fremstår jordejendommen for kapitalen ved dens anlæg i bygge- og landbrugsjord eller fremstår jordbesidderen for kapitalisten«. (Das Kapital, s. 770, min overs. OFK.)

I Marx' begreb »den absolutte jordrente « ligger den grundforudsætning, at de realiserede ekstraprofitter også er produceret. Der er ikke tale om et forhold mellem kapitaler indenfor denne branche - det er derimod Ricardos eneste perspektiv på jordrenteproblematikken. Bringes forholdet mellem kapitaler indenfor landbrugssektoren derimod ind, - og det gør det i begrebet »differentialrente« - så bæres ekstraprofitterne ikke længere af produceret værdi.

$\gg$ Absolut rente er vardiens overskud over råproduktets produktionspris. Differentialrente er markedsprisens overskud hos de produkter, der er dyrket på gode jorde, over deres egen produktvardi«. (Theorien über den Mehrwert, bd. II, s. 138. Marx's fremhævelser, min oversættelse. OFK.) $)^{15}$

Denne situation, - der i industrien aldrig vil kunne være permanent, dels fordi der dér ikke hersker nogen institutionel skranke for kapital, dels fordi produktiviteten kan forøges absolut, dvs. at der ingen naturmæssigt givne begrænsninger er for produktivitetsudviklingen (som i landbruget), - kan kun være permanent $\mathrm{i}$ helt særlige tilfælde.

Selv en højproduktiv branche med stoflige grænser for højt værdiindhold i produkterne kan ikke vedblive med at realisere ekstraprofitter, fordi dens teknik vil blive billigere, større kapitaler vil trænge ind og forøge udbuddet og mindre kapitaler på baggrund af de billigere produktionsmidler hæve markedsværdiniveauet, (så branchen ikke »tager værdi« fra de andre ved dannelsen af sine produktionspriser).

Kun hvor særlige forhold skaber en naturgiven disharmoni i udbudefterspørgsels-mekanismen, så udbuddet aldrig kan besvare efterspørgslen fuldt ud, kan markedsværdier regulere prisniveauet, der indebærer, at profitterne realiseret i branchen permanent ligger over gennemsnittet i samfundet. Dette er sikkert tilfældet i olieindustrien.

Det er nu min tese i denne artikel, at staten gennem sin politisk betingede efterspørgsel på boliger, erhvervsvirksomheder og andre varer fra bygge- og anlægssektoren vil gøre skabelsen af »falsk social værdi« mulig dér. Dette skyldes at den intense og permanente efterspørgsel skaber et markedsværdiniveau i denne sektor, der ligger højere end i resten af samfundet. De mindst

15. Dette citat har Marx skrevet på engelsk. Begrebet »Durchschnittspreis« (average price) oversættes her - tro mod den generelle betydning i bd. II af Theorien über den Mehrwert - med begrebet »produktionspris«. 
produktive, altså mest arbejdsintensive virksomheder kan altså regulere markedsværdiniveauet i denne branche og dermed sikre en ekstraprofit til alle andre kapitaler. Naturligvis kan dette markedsværdiniveau kun være permanent så længe de politiske beslutninger sikrer efterspørgslen og dermed holder denne sektor ude af den reproduktionscirkel, der reguleres af kræfternes frie spil, dvs. af prisstigninger og -fald som følge af kapitalbevægelser til og fra branchen (sektoren).

Som nævnt er det ikke uproblematisk at lade de forhold, der er opremsede for en sektor som landbrugssektoren med henblik på kornproduktion gælde for en sektor som bygge-anlægs. Thi hvor produktet kvalitativt og kvantitativt er ensartet i landbrugssektoren (det er nemlig korn), så er bygge-, anlægssektorens produkter vidt forskellige. Det betyder at der ikke dannes en konkret enhedspris, fordi der går forskellig mængde konstant og variabel kapital, fix og cirkulerende kapital ind i henholdsvis produktionen af et egeparket og af en wc-kumme.

Alligevel kan Marx's begreb »falsk social værdi«, der refererer til et ensartet brancheprodukt og dermed til en enhedspris i bogstavelig forstand, accepteres her, fordi produkterne i bygge-, anlægssektoren indgår omtrent identisk i reproduktionen: de har næsten ens funktion i den produktive og private konsumtion - med undtagelse af visse udprægede luksusartikler. Branchelovene kan her anvendes således, at sektoren ikke skal producere den værdi den realiserer i et snit gennem tiden, over et år f.eks., men nok over en hel cykel eller i alt fald tendere imod det. Samtidig gælder, at det nu er de lavest sammensatte branchers markedspriser, der regulerer profitniveauet, ved at foreskrive et profitniveau. Ved konstant m' vil disse kapitaler naturligvis have den største merværdimasse, og da de altså realiserer den hele kan de eksemplarisk foreskrive resten af sektoren samme profitniveau som minimal grcense. Dette kan lade sig gøre, fordi efterspørgslen på disse - af stoflige årsager bl.a. arbejdsintensive kapitaler - er så permanent at selv kapitaltilførsel til disse brancheprodukters produktion ikke sanker markedsvardiniveauet. Det permanente eftersp $\phi r g s e l s o v e r s k u d$ på denne sektor g $\phi r$ altså, at den samme profit kan realiseres ved at anlagges i et andet brancheprodukt indenfor sektoren. Således afbødes virkningerne på produktionspriserne og på markedsvardierne af den - p.g.a. det »permanent « høje profitniveau - accellerende kapitaltilførsel.

Et andet moment, der uden egentlige institutionelle skranker for kapitaltilførsel - såsom monopol på jord - alligevel kan forhale ekstraprofitniveauets fald er visse brancheprodukters krav om meget høj kapitalanlægsgrænse og muligheden for at anlægge profitabel kapital i meget små og arbejdsintensive håndværksfirmaer. Dette gælder også - som vi skal se - for bygge-, anlægssektorens to hovedleverandør-brancher (brancheklynger): sten-, ler- og glasindustri og træ- og møbelindusri. Også hos dem kan ekstraprofitterne opretholdes i længere tid end det har været tilfældet i de øvrige brancher.

Pointen her er altså, at en situation, der af resultat ligner den, der avlede differentialrenterne, er mulig ved et så stort efterspørgselspres, at kapitalbevæ- 
gelserne ikke i sædvanlig grad kan udligne pris- og profitniveauet gennem en forøgelse af udbuddet, (at dette også har stoflige årsager ser vi af bygge-, anlægssektorens små og arbejdsintensive virksomhedstyper, der bl.a. har reperation som arbejdsindhold, en funktion, der er svær at forbinde med en voldsom accelleration af produktionsmidlerne).

Selvom årsagerne til de permanente ekstraprofitter her altså ikke er de samme som i landbrugssektoren før og delvis efter ophævelse af The Corn Laws i 1848, så er deres virkninger i vid udstrækning de samme hvad angår totalreproduktionen.

Disse virkninger er følgende:

a) Blokering af dannelsen af gennemsnitsprofitraten og produktionspriserne i samfundet, dvs. ulige produktivitetsudvikling og derfor blokeringer i reproduktionsprocessen eventuelt gennem varemangel, der så giver sig udtryk i betalingsbalanceforværringer p.g.a. den forøgede import, ect.

b) Fald i reallønnen for nogle lønmodtagergrupper p.g.a. fordyrelse af f.eks. boligudgifterne og dermed et yderligere lønpres. Dette lønpres i forening med det lønpres, som den stigende progressive beskatning til forøgelse af de offentlige udgifter til køb hos sektoren giver, skaber valoriseringsvanskeligheder for kapitalen p.g.a. stigninger i den variable kapital. (Yderligere vanskeligheder kan skabes gennem boligfordyrelsens påvirkning af forbrugsmønsteret. $)^{16}$

Dette virker igen ind på akkumulationsmønsteret idet tendensen til at forøge produktionen gennem en udvidelse af den konstante kapital på bekostning af den variable accentueres.

Ricardo formulerer helt klart denne katastrofale virkning på den kapitalistiske $\varnothing$ konomi af manglende koordinering med produktivitetsudviklingen i resten af samfundet hos den sektor i samfundet, hvis produkt indgår som hovedbestanddel i arbejdskraftens værdi.

»Med enhver stigning i (total)-kapitalen og befolkningen vil fødevarerne almindeligvis stige, da de vil være vanskeligere at producere. (Ifølge loven om differentialrenterne. OFK.) Konsekvensen af en stigning i fødevarerne vil være en stigning i lønningerne, og enhver stigning i lønningerne vil have en tendens til at lede den opsparede kapital hen til investering i (konstant) kapital i en proportion større end det tidligere var tilfældet. Maskineri og arbejdskraft befinder sig i permanent indbyrdes konkurrence, og den første (type kapital) anvendes ikke før arbejdets (arbejdskraftens) værdi stiger.« (Principles of Political Economy and Taxation. Everymanudgaven. s. 270, Min overs. og paranteserne er indføjet af mig. OFK.)

c) Valoriseringsbesvær som følge af kapitalbeskatningen og fordyrelsen af konstant kapital af typen »erhvervsbyggeri«, ect.

16. Olav Grue: Byggevirksomheden og den $\varnothing$ konomisk uvikling, Studier fra Københavns Universitets Økonomiske Institut, nr. 12, København 1967. kap. 8. 
d) Vanskeligheder for nationalkapitalen på verdensmarkedet p.g.a. det høje nationale prisniveau. Valutarisk usikkerhed, ect.

e) Betalingsbalancebesvær p.g.a. de offentlige lån i udlandet til at financiere den offentlige sektor med.

(Yderligere resultater og disses systematiske bestemmelse er emnet for del II.)

Man må nu stille det spørgsmål i forbindelse med min bestemmelse af skabelsen af »falsk social værdi« som det knudepunkt hvorudfra statsinterventionen skal forstås: hvorfor kan problemet ikke udelukkende løses således, at inflationsvirkningen af det udsædvanligt høje prisniveau i visse sektorer eller brancher eller brancheklynger forklares ud fra det forhold, at der simpelthen produceres mere vaerdi dér?

Her gælder det, at kapitalintensiteten og kapitalbevægelserne gør denne løsning både empirisk og logisk uacceptabel. Empirisk set er den ikke rimelig fordi kapitalsammensætningen er høj i denne sektor indenfor en række firmaer og fordi kapitalen er stor i forhold til andre brancher og sektorer. Logisk kommer den i konflikt med tesen om princippet for dannelsen af gennemsnitsprofitraten og produktionspriserne: at der vil sive store kapitaler ind i en sektor med så lav en sammensætning og så højt et markedsniveau og så stor en efterspørgsel og dermed vil produktiviteten stige.

Man må nemlig gøre sig klart, at et højt markedsværdiniveau indenfor en sektor ikke behøver betyde at kapitalsammensatningen dér er lav. Derimod viser det, at efterspørgslen overgår udbuddet og at stoflige og politiske forhold gør denne efterspørgsel permanent og blokerer for at den besvares gennem en adækvat forøgelse af udbuddet.

At der findes mange arbejdsintensive virksomheder i bygge-, anlægssektoren p.g.a. arbejdets håndværksmæssige organisering og reperationsarbejdets andel af totalarbejdet betyder ikke, at produktiviteten generelt er lav i denne sektor og at ekstraprofitten derfor også er produceret, at der altså er tale om præcis den samme situation som ved »den absolutte jordrente«. At efterspørgslen permanent overgår udbuddet i boligsektoren skyldes at denne efterspørgsel nødvendigvis må blive en efterspørgsel på nye boliger, fordi efterspørgslen på ældre boliger er helt overeksponeret p.g.a. huslejepolitikken. ${ }^{17}$

De ekstraprofitter, der realiseres på nybyggeri og som giver en »overnormal forrentning af den investerede kapital ${ }^{18}$, er ikke resultat af en lav sammensætning af denne kapital - den er meget høj i forhold til den kapital, der anvendtes ved tidligere boligbyggeri, og den ligger på linie med sammensætningen i kapitalen andre steder i samfundet. (At differentialrentebegrebet kan anvendes i forbindelse med byggeriet er indlysende - som jeg også skal uddybe i næste afsnit).

17. Grue, ibd. s. 159.

18. Grue, ibd. s. 157. 
Loven om produktionspris- og gennemsnitsprofitratedannelsen, der er den mest funktionskraftige lov i hele Marx's teori om kapitalismen, indebærer altså, at en forklaring gennem værdiproduktion af de nævnte forhold kun er mulig $\mathrm{i}$ en situation, hvor der er tale om en monopolsituation og om naturgivne blokeringer for produktivitetsudviklingen. En situation der hører til i landbruget i det 19-nde århundrede og ikke i bygge-, anlægssektoren i det 20-nde.

Derimod kan påpegningen af en arbejdsintensiv kapital i denne sektor og den lave organiske sammensætning i en række små virksomheder være et delmoment af en forklaring, men aldrig andet. Loven for dannelsen af produktionspriserne og gennemsnitsprofitraten, der indebærer $\emptyset$ get kapitaltilførsel til en sektor med et højt markedsværdiniveau, medfører, at et permanent markedsværdiniveau i skyerne aldrig kan være resultatet af reelt brancheproduceret værdi, men må være resultatet af en forskydning mellem produceret og realiseret værdi som det ligger i begrebet »falsk social værdi

Vort perspektiv på forholdet mellem stat og kapitalistisk samfund i en given historisk fase af dettes udvikling, hvor statsfunktionerne påvises at måtte justeres til lovmæssighederne for dannelsen af gennemsnitsprofitraten og produktionspriserne indebærer også, at en mere konkret tilgang til begreberne produktionspris og gennemsnitsprofitrate er nødvendig.

Denne kan kun gives når man i sin talen om »falsk social værdi« indenfor en sektor har et konkret niveau at udgå fra, et niveau, der kvantitativt afgrænser indholdet af begrebet »falsk social værdi« på totalsamfundsmæssigt plan. Dette niveau er niveauet for profitraten i enkelte af de dominerende brancher i industrien, her i de virksomheder givetvis, der producerer arbejdsmaskiner til hele industrien.

Marx viser tydeligt selv at dette er nødvendigt, for uden et kendskab til gennemsnitsprofitraten i industrisektoren (eller enkelte af dens brancher, hvor produktivitetsniveauet er udlignet) kan begrebet produktionspris i industrien ikke udvikles, og begrebet »absolut jordrente « bliver da meningsløst, fordi der ikke er noget niveau jordejeren og forpagteren kan tage som udgangspunkt for deres pagt. Thi pagtens kerne indebærer, at kun de jorde vil blive forpagtet, (af en kapitalist), der er så produktive, at salget af deres produkter kan give både gennemsnitsprofitraten $o g$ jordrenten i dennes laveste rate. Dvs. kun hvor kapitalerne kan være så arbejdsintensive (stor $\mathrm{V} \ll$ ), at det kan give en merværdi, der indeholder både gennemsnitsprofitraten og renten, er forpagtningen mulig.

Men for at kapitalisten kan vide om han skal forpagte en given type jord eller ej og for at jordejeren skal vide om han kan leje den ud, så må kapitalisten vide hvor meget profit han kan forvente og jordejeren vide hvor meget rente han kan kræve. Altså må man antage at forventningen har en realitet at hente sit forventede fra, og det kan kun være et accepteret, som erfaringsfaktum oplevet profitniveau.

Dette skaber dog ikke overvældende problemer, fordi gennemsnitsprofitraten i industrisektoren blot kan opfattes som den profit, der realiseres på de 
gennemsnitsligt sammensatte og branchedominerende kapitaler i de vigtigste brancher af SI (produktionsmiddelsektoren). Altså at to eller flere brancher i industrien indenfor en kortere periode giver samme afkast på ens sammensatte kapitaler. (Dette betyder ikke nødvendigvis at disse kapitaler er absolut lige store, men de vil givetvis også være en tendens i denne retning).

Her hører Marx's udsagn om, at gennemsnitsrentefoden (her er tale om rente af kapital, ikke om jordrente) følger gennemsnitsprofitraten i store træk, for rentefoden er selvfølgelig - foruden en minimalprofit - bundgrænsen for et forventet kapitalafkast, hjemme. ${ }^{19}$

Der er altså logisk set hjemmel nok i Marx's arbejder for at søge indikatorer af konkretere art for gennemsnitsprofitraten og produktionspriserne. Marx opfatter da også selv i Theorien über den Mehrwert prisindekser for landbrugsprisernes bevægelser som tal, hvoraf man direkte kan aflæse produktionspriserne. ${ }^{20}$

\subsection{Afsluttende opsummering af begrebernes indhold:}

Lad mig afslutte dette teoretiske afsnit med at præcisere forholdet mellem det dynamiske og statiske indhold af begreberne »markedsværdi« på den ene side og »gennemsnitsprofitrate« og »produktionspris« på den anden side:

Om markedsværdien gælder altså følgende:

\section{A) Dynamisk indhold:}

Her er dens indhold, at den prissum, der realiseres indenfor en branche indenfor en cyklus vil være dækket ind af summen af de individuelle værdier produceret dér. Markedsværdien udgør altså et aritmetrisk gennemsnit af produktivitetsniveauer indenfor branchen gennem cyklusen. Det betyder selvfølgelig ikke at markedsværdien statisk set er identisk med det aritmetriske gennemsnit af de individuelle værdier produceret indenfor branchen $\mathrm{i}$ et kortere tidsrum, men derimod at dens værdiindhold hopper op og ned omkring dette ideelle, konstruerede gennemsnit, og må hoppe ned, hvis den har stukket hovedet for langt op og omvendt.

Det betyder, at man - naturligivs med en række modifikationer så som den forudsætning at guldfoden er konstant eller at valutaen er det, ect. - kan tage prisstørrelser som direkte indikatorer på værdibevægelser.

19. Das Kapital, bd. III, s. 377-378.

20. Theorien über den Mehrwert, bd. II, s. $127 \mathrm{ff}$. Marx taler om »Durchschnittspreise«, men s. 123 defineres disse som »produktionspriser«, og når han s. 203 i bd. II af Theorien über den Mehtwert siger: »Den virkelige markedspris står snart over snart under denne markedsværdi og er kun tilfældigt identisk med den. Men over en vis periode udlignes udsvingene, og man kan sige, at gennemsnittet af de virkelige markedspriser er den markedspris, der udtrykker markedsvardien. « (Min overs. Marx' fremhævelser. OFK.) opfatter han altså gennemsnitspriser som $=$ markedsværdien . 
Markedsværdien som tendens indebærer ifølge sit væsen, at der indenfor en branche vil dannes et ensartet teknisk niveau hos en stor del af firmaerne. Dermed vil disse firmaer producere og realisere en gennemsnitsprofit alt afhængig af branchens placering i totalreproduktionen, dvs. om dens stoflige forudsætninger giver den en for lav eller for høj sammensætning i samfundsmæssig målestok.

Endelig er »markedsværdien« som begreb - hvad enten det udtrykker en tendens eller noget statisk - udtryk for det forhold, at der er en essentiel forskel mellem relativ merværdi og ekstramerværdi. Ekstramerværdien kan aldrig forklares ud fra en given kapitals værdiproduktion, men må forklares ud fra en systematisk forskel mellem værdiproduktion og værdirealisering. Forklarer man derimod ekstramerværdien eller ekstraprofitten ud fra en kapitals værdiproduktion, så subjektiviserer man værditeorien, man reproducerer altså Böhm-Bawerks ${ }^{21}$ indvendinger netop mod Marx's endegyldige bestemmelse af prisbevægelserne i konkurrencen ud fra værdien som objektiv værdi.

Identificerer man relativ merværdi og ekstramerværdi siger man altså, at alle prisbevægelser bestemmes af efterspørgslen - og så forlader man værditeorien eller indfører et begreb for yderligere værdiproduktion som det ligger i begrebet »kompliceret arbejde« og som Ole Marquardt ${ }^{22}$ så glimrende har jævnet med jorden, såfremt det tolkes som et begreb der angår værdiproduktionen.

Eller også begår man den fejl som hele Marx's tænkning er rettet mod at tilintetgøre: forestillingen om produktionsmidlernes værdiskabende evne. Man reproducerer altså den »trinitariske formels illusioner « og hævder - om man vil det eller ej - at årsagen til at nogle kapitaler kan realisere en ekstraprofit skyldes at de producerer den. Og da det ligger i hele akkumulations-perspektivets essens, at produktivitetsudvidelse $i$ princippet foregår gennem udvidelse af den konstante kapital på den variables bekostning, så kan det altså kun være produktionsmidlerne, der »producerer « den omtalte ekstramerværdi, da merværdiraten forudsættes konstant. At merværdiraten ikke kan optræde som forklaringsinstans her kan fastlægges ud fra det forhold, at dens stigning skal være lidt højere end omvendt proportional med det absolutte fald i den variable kapital - et forhold, der næppe er empirisk generelt, dvs. er type-forholdet mellem $\mathrm{k}$ og v i akkumulationsbevægelsen. Og det kan fastlægges, fordi merværdiraten slet ikke er noget begreb, der angår enkeltkapitalen i det øjeblik vi har en konstant arbejdsdag, en nogenlunde fast mindsteløn og stramme normer for overarbejde. Merværdiraten angår da blot produktivitetsforholdet i sektor II (konsumtionsmiddelsektoren), og den konstante merværdirate som er Marx's præmisse ved enhver behandling af kon-

21. Böhm-Bawerk: Zum Abschluss des Marxschen Systems, trykt i Aspekte der Marxschen Theorie 1, Zur Methodischen Bedeutung des 3. Bandens des »kapital«, udg. af F. Eberle, Suhrkamp, 1973.

22. Ole Marquardt: En kommentar til den såkaldte reduktionsproblematik og dennes betydning for den marxske arbejdsværditeori. Fagtryk, februar 1975. 
kurrencens begreb, er da både empirisk indløst $o g$ logisk nødvendig af hensyn til ikke at blande relativ merværdi og ekstramerværdi sammen, da forestillingen om at ekstraprofitten er produceret er bundet til troen på at merværdiraten er forøget hos en række individuelle kapitaler.

At Marx i begyndelsen af Theorien über den Mehrwert bd. II selv gennem sin udvikling af differentialrentebegrebet på baggrund af Ricardos geniale indsigter laver den omtalte fejl og tager fat med at begrunde ekstraprofitten i landbruget på de frugtbareste jorde og på de jorde med mest anlagt kapital ud fra en produceret værdi, sætter netop denne fejltagelse i perspektiv, fordi han omkring s. 100 selv bryder med den og implicit begynder at operere med begrebet »falsk social værdi«. Fejltagelsen indebærer Ricardos vage forestillinger, der synes at indikere, at differentialrenterne er dækket værdimæssigt ind. Selvom der i Ricardos begreb »relative value « ligger indhold, der kan synes at befri ham fra den omtalte fejltagelse - som den Marx, der har erkendt begrebet »falsk social værdi«, nu netop kan beskylde ham for: nemlig for ikke at have »udviklet og begrebet ... forskellen mellem produktionspriser (Marx kalder her sin vane tro "produktionspris« for »Kostpreis«, OFK.) og værdi...« selv om han dog »faktisk har konstateret den.« (Theorien über den Mehrwert, bd. II, s. 196. Min overs. OFK.)

\section{B) Statisk indhold}

Statisk set er markedsværdien udtryk for det forhold, at et givet prisniveau indenfor en branche vil svare til en indenfor denne branche faktisk eksisterende produktivitet, dvs. at markedsværdien vil ligge et sted mellem de grænser som sættes af den laveste og højeste individuelle vareværdi.

Markedsværdien som statisk størrelse, som affotograferet prisstørrelse, viser, at det er produktiviteten, dennes spredning på virksomheder og udbudefterspørgselsmekanismen, der afgør markedsværdiniveauet.

Markedsværdiniveauet reguleres som følger indenfor det niveauhierarki, som sættes af totalsummen af individuelle vareværdiers niveau, der ifølge produktionsprisens begreb over kortere perioder sagtens kan overskrides.

Lad mig afslutte præciseringen af markedsværdiens dynamiske og statiske indhold med følgende betydningsfulde citat fra bd. II af Theorien über den Mehrwert, s. 201-202, der efter min opfattelse bekræfter den fortolkning af markedsværdibegrebet, der er blevet udviklet i denne teoretiske fremstilling af konkurrencens begreb. ${ }^{23}$

Det fremgår af følgende citat helt klart, at markedsværdiniveauet tendentielt ligger på det aritmetriske gennemsnit af totalværdien produceret indenfor branchen over en cyklus, og at markedsværdien her indikerer et faktisk etableret produktivitetsniveau, der vil dominere en række virksomheder, og at dette produktivitetsniveau vil ligge på et mellemtrin af produktivitet indenfor branchen. Dette

23. Den trinitariske formel, se Das Kapital bd. III og Theorien über den Mehrwert, bd. III. 
sidste hører sammen med at cyklusen er den proces, hvori en given type konstant kapital udvikles, dominerer og forældes, og her tror jeg snarere Mandels cyklusbegreb, »den lange bølge«, der netop er afstemt efter teknikkens udvikling passer bedre som enhed for den processuelle værdi-pris-identitet end de traditionelle cyklusstørrelser: 7-8 år. ${ }^{24}$ Dette er indholdet af første afsnit i citatet. Andet afsnit belyser, at markedsværdiniveauet er afhængigt af produktivitetsniveauet, af det virksomhedsantal indenfor branchen, der repræsenterer det, samt af hvor stor en repræsentation af de andre trin det sameksisterer med over en kortere periode, samt endelig af udbud-efterspørgselsmekanismen:

»Værdien af en vare - der er produktet af en bestemt branche - er bestemt af den mængde arbejde, der er påkrævet, for at producere hele mangden, totalsummen af den produktionssfæres vareprodukt, og ikke af den særlige arbejdstid, der er påkrævet af hver enkelt kapitalist eller arbejdsgiver indenfor denne branche. De almene produktionsbetingelser og arbejdets almene produktivitet i denne særlige branche, f.eks. bomuldsfabrikation, er de gennemsnitslige produktionsbetingelser og den gennemsnitlige produktivitet indenfor denne branche: bomuldsfabrikation. Den kvantitet arbejde, hvorigennem f.eks. en alen bomuldsklæde er bestemt, er ikke den kvantitet arbejde der er den iboende, som fabrikanten har anvendt ved produktionen af den, men den gennemsnitslige kvantitet, hvorved alle bomuldsfabrikanter på markedet producerer en meter bomuldsklæde. De særlige betingelser, hvorunder de enkelte kapitalister producerer indenfor bomuldsfabrikationen, falder med nødvendighed i tre klasser. Den ene producerer ved middelbetingelser, det betyder, at de individuelle produktionsbetingelser, hvorunder de producerer, falder sammen med de almene produktionsbetingelser indenfor branchen. Gennemsnitsforholdet er dens virkelige forhold. (Middeltypens. OFK.) Dens arbejdsproduktivitet har den gennemsnitslige højde. Dens varers individuelle værdi falder sammen med varernes almene værdi. Hvis den (den midterste kapitaltype) f.eks. sælger bomuldsklædet for 2 shillings per alen, - hvilket er gennemsnitsværdien - så sælger den varerne til den vardi, som de af denne kapitaltypes kapitalister producerede alen faktisk indeholder. En anden klasse af kapitaler producerer under betingelser der er bedre end de gennemsnitslige. Deres individuelle vareværdier står under varernes almene værdi. Sælger de varerne til den almene værdi, så sælger de dem over deres individuelle værdi. Endelig producerer en tredie klasse under de gennemsnitslige produktionsbetingelser.

Men den produktmængde, der efterspørges fra denne branche er ingen fast størrelse. Går nemlig vareværdierne ud over visse rammer for gennemsnitsværdien, så falder mængden af den efterspurgte produktmængde, eller denne kvantitet efterspurgtes kun ved en given pris - eller i det mindste indenfor visse prisgrænser. Det er altså ligeså muligt, at den sidste klasse til stadighed må sælge deres varer under deres individuelle værdi, ligesom den bedstproducerende klasse til stadighed sælger varerne over deres individuelle værdi. Det vil nemlig afhænge af det numeriske forhold, eller af den proportionelle fordeling af virksomheder mellem klasserne, hvilken klasse, der vil afgøre gennemsnitsværdien. Hvis midterklassen er den langt mest dominerende, så vil den afgøre gennemsnitsværdien. Er denne klasse numerisk svag og den der producerer under gennemsnitsproduktionsbetingelserne numerisk stærk og dominerende, så vil den (dens individuelle produktværdi, OFK.) afgøre brancheproduktets almene værdi, selvom det hermed ikke skal være sagt, ja, at det er meget usandsynligt, at det netop skulle være den enkelte kapitalist i den sidste klasse af kapitaler, altså den dårligst producerende, der bestemmer afgørelsen«. (Marx’s fremhævelser. Min overs. OFK.)

Her kræves nemlig ekstraordinære betingelser af f.eks. politisk art, som det er tilfældet i bygge-, anlægs-sektoren, hvor det faktisk er de dårligste produktionsbe-

24. Mandel: Der Spätkapitalismus, Suhrkamp, 1973, kap. 4. 
tingelser, altså den højeste individuelle værdi, der regulerer markedsværdiniveauet. Overgangen til produktionsprisbegrebet bestemmes af det forhold at værdien af branchens totalprodukt over en given, kortere periode (som påpeget ikke en cyklus, hvad angår type-eksemplet), kan afvige fra den totale prissum det realiseres til.

Hvor ensartet pris på alle brancheprodukter, totalidentitet mellem værdi og pris over en cyklus, forskelligt profitrateniveau, og tendens til udligning af produktivitetsforskellene, en bevægelse, der rent faktisk repræsenteres af det midterste produktivitetsniveau alt efter mulighederne for dets numerisk stærke repræsentation blandt virksomhederne i branchen, vil regulere markedsværdien, så vil dette princip blive fraviget ved dannelsen af produktionsprisen, thi her kan profitten kun være ens mellem brancherne under den forudsætning, at der ikke dannes en enhedspris på produkterne. Og på baggrund af de helt forskellige stoflige forudsætninger for at producere automobiler og spagetti er det indlysende, at denne ensartede profit kun kan opnås ved at værdi og pris systematisk afviger fra hinanden i forholdet mellem brancherne, men er identisk på totalplan over en cyklus.

Marx præciserer tydeligt dette:

»Hver særlig branches markedsvardier, altså hver særlig branches markedspriser (hvis markedsprisen blot udgjorde »den naturlige pris« (Ricardos udtryk for individuel værdi. OFK.) altså blot udtrykte værdien i penge) ville give meget forskellige profitrater, da lige store kapitaler i hver forskellig branche (helt bortset fra de forskelle, der resulterer af deres forskellige cirkulationsprocesser) anvender konstant og variabel kapital i meget forskellige proportioner, altså giver meget forskellige merværdimasser og dermed profitmasser. Udligningen af de forskellige markedsværdier, således at den samme profitrate opstår indenfor de forskellige brancher, lige store kapitaler altså afkaster sammen gennemsnitsprofitter, er altså kun mulig gennem det forhold, at markedsvardierne forvandles til produktionspriser, der er forskellige fra de virkelige værdier « (Theorien über den Mehrwert, bd. II, s. 205, Marx's fremhævelser, min overs. OFK.)

Om gennemsnitsprofitraten og produktionspriserne gælder altså følgende:

\section{A) Dynamisk indhold:}

Dynamisk set er produktionspriserne og gennemsnitsprofitraten udtryk for, at kapitalen fordeles sådan på alle brancher, at profitniveauet i en branches livsforløb i forhold til alle brancher vil finde et ensartet niveau. Ekstra- eller minusprofitter kan ikke være noget permanent så længe produktet spiller en rolle for totalreproduktionen, dvs. så længe kapital kan tilføres og efterspørgselen variere.

Ricardo formulerer dette forhold kort og præcist:

»Det er det $\varnothing n s k e$, som enhver kapitalist har om at flytte sine midler fra en mindre til en mere profitabel produktion, der forhindrer varernes markedspris i kontinuerligt at stå meget over eller meget under deres naturlige pris. Det er denne konkurrence, der i en sådan grad adjusterer varernes bytteværdi, at den tiloversblivende værdi eller overskydende masse, der er tilbage efter at lønnen for det arbejde, der er nødvendigt for deres produktion er betalt, foruden alle de andre udgifter, der kræves for at reproducere kapitalen på dens oprindelige niveau, indenfor enhver branche vil være proportional med den investerede kapitals størrlse.« (Ricardo: The Principles of Political Economy and Taxation. Everyman-udgaven, s. 50, Min overs. OFK.) 
Produktionsprisen kan i sit dymaniske aspekt ikke konstateres som et håndgribeligt, endeligt-etableret prisudtryk, men kommer til udtryk i det forhold, at der mellem brancherne enten må dannes et markedsværdiniveau med samme profitter $\mathrm{i}$ hovedparten af virksomhederne - hvilket naturligvis kun er muligt i brancher med samme stoflige betingelser for produktion - og/eller at ekstra- og minusprofitterne over cyklusen vil udligne hinanden. Som tendens kan dannelsen af gennemsnitsprofitraten og produktionspriserne indebære - ifølge dennes væsen - at totalpriserne på brancheproduktet kan ligge over totalværdierne indenfor en cyklus. Dette er et atypisk tilfælde hvad angår markedsværdibegrebet, da det korrigerer dette, men det er typisk nok hvad angår begrebet produktionspris, i hvis indhold begrebet »falsk social værdi « jo faktisk indgår konstituerende. Kun muligheden for afvigelsen mellem værdi og pris gør en faktisk såvel som tendentiel gennemsnitsprofitrate mulig.

Det tilfælde jeg her har i tankerne er tilfældet med den højproduktive branche, eller den lavproduktive branche, der ifølge stoflige årsager - undtagen landbruget og bygge-, anlægssektoren - ville ligge langt under og langt over gennemsnitsprofitten, hvis de »kun « skulle realisere den af dem producerede merværdi som profit.

Gennemsnitsprofitraten og produktionspriserne udtrykker altså, at sådanne underskud på brancheplan i værdi må opvejes af overskud på totalplan - thi ellers ville værdi og pris variere på totalplan - i alt fald hvis vi betragter et lukket (nationalt) system.

Dette sætter sig ikke igennem ved hjælp af hekseri, men betyder bare, at en ujævn fordeling af teknik og ressourcer, samt teknikkens stykvise og disproportionale udvikling i det kapitalistiske samfund gør det muligt, at varer produceret ved høj teknisk standard ikke sænkes tilsvarende i værdi når de sælges.

\section{B) Statisk indhold:}

At prisniveauet i en højproduktiv branche i dele af cyklussen ligger langt over den producerede værdi gør det selvfølgeligt vanskeligt at vide om pris indikerer værdi for et brancheprodukt. Her kan man dog skele til kapitalstørrelse, output og arbejdstimeantal for at se, hvad man kan tillade sig at slutte. Også ved tilfældet »falsk social værdi « ligger produktionsprisen borte fra markedsværdiniveauet, men i modsætning til den højproduktive branche, hvor produktionsprisen lå over markedsværdiniveauet (hvis dette udtrykker det aritmetriske gennemsnit af den over cyklussen producerede totalværdi i branchen, altså summen af individuelle værdier), ligger produktionsprisen nu under markedsværdiniveauet uden at dette markedsværdiniveau på totalplan over kortere tid er dækket ind, selvom markedsværdiens konkrete prisniveau udtrykker en konkret kapitaltype. Men disse tilfælde er alligevel atypiske hvad angår den helt generelle tendens for konkurrencen: udligning af produktivitetsniveauer og af profitrater.

I og med produktionsprisen jo betyder, at kapital med samme absolutte størrelse realiserer samme værdi uanset dens sammensætning, er det proble- 
matisk om man kan tale om produktionsprisen som et »statisk « begreb, som en affotograferbar størrelse. Thi begrebet en ensartet produktionspris i betydning et ensartet, numerisk identisk prisniveau er en kontradiktion. En ensartet pris kan kun give en ensartet profit, hvis alle kapitaler er ens sammensat. Men det er per difinition en ophævelse af konkurrencens begreb.

Produktionsprisen og gennemsnitsprofitraten eksisterer som statiske begreber, som direkte indikatorer for værdibevægelser i to tilfælde:

I) Hvor to eller flere brancher er så essentielle for totalreproduktionen, at profitniveauet i deres hyppigst repræsenterede kapitalsammensætning eksemplarisk regulerer profitniveauet i de andre brancher ved at sætte dets bundgrænse. Der skal her være tale om brancher med en støt, ikke-sæsonbestemt efterspørgsel og ikke overkapitaliserede brancher. Dette kan accepteres, da dette profitrateniveau trods alt kun kan være permanent indenfor kortere tid i cyklusen, og det er da også - som nævnt - den forestilling der bl.a. konstituerer Marx's begreb »den absolutte jordrente«.

II) Hvor kapitalens organiske sammensætning er så forskellig i alle brancher p.g.a. stoflige forskelligheder i produktionsteknik og produktform og funktion, at et numerisk identisk prisniveau ville være latterligt, dér dannes produktionspriserne netop som ensartede profitter på helt forskellige priser, da jo alene forskellige priser på forskelligt sammensatte kapitalers produkter gør en ensartet profit mulig. (Se her skemaerne i forbindelse med illustrationen af gennemsnitsprofitratebegrebet i Das Kapital, bd. III, s. 166 ff.)

At hver branches totalkapital ikke realiserer mere end gennemsnitsprofitten er bestemt af udbud-efterspørgsels-mekanismen, af de relativt faste produktionskoefficienter indenfor dele af cyklusen, og af merværdiratens ensartethed i hele samfundet. Denne sammenhæng udtrykkes ofte metaforisk i det vage begreb »værdioverførsel«, der har status af beskrivelse, ikke forklaring.

Begrebet produktionspris som fotograferbar term skulle betyde, at man direkte af priserne på brancheproduktet skulle kunne aflæse profitten. Det er selvfølgelig kun korrekt under meget særlige omstændigheder, fordi afgivelserne mellem ekstra- og minusprofitter kun kan opsummeres, hvis man kender en del til forholdene indenfor branchen i forhold til resten af samfundet.

Det kræver kendskab til de stoflige forskelligheder i produktionsbetingelserne at kunne aflæse profitbevægelserne indenfor de forskellige brancher, fordi profitstørrelserne i den borgerlige statistik tillige med omkostningsprisens indikatorer er temmeligt utilregnelige.

Men her gælder, at man må arbejde med det borgerlige materiale, der foreligger, og at man faktisk i vid udstrækning kan klare sig med indirekte indikatorer, ds. statistisk ikke behøver arbejde med begreber som variabel og konstant kapital, merværdi, merværdirate ect. 


\section{Kapitel 3}

\section{Sektor III's valoriseringsbetingelser}

I det følgende skal de foregående teoretiske overvejelser anvendes til at drage konklusioner om statsinterventionens objektive grundlag. Gennem inddragelsen af Marx' reproduktionsskemaer kan en tredie sektor udvikles (sektor III, skrives i det følgende SIII), der udgør alle de brancher, der direkte nyder godt af statens efterspørgsel i større målestok.

Pointen i det følgende bliver da, at gennemsnitsprofitraten i samfundet ikke indføres i denne sektor III og i vid udstrækning heller ikke i dens hovedleverandørbrancher, men at der her findes en højere profitrate og at denne kan vedvare på trods af forøget kapitaltilførsel.

I denne sektor og i dens leverandørbrancher findes altså et højere markedsværdiniveau i forhold til den stofligt mulige produktivitet end i det $\varnothing$ vrige samfund, fordi efterspørgslen er så stærk, at forøget kapitaltilførsel og dermed forøget udbud ikke vil sænke markedsværdiniveauet.

Statistikken giver ikke nogen mulighed for at bestemme om det er det laveste eller et lidt mindre lavt produktivitetsniveau, der regulerer markedsværdiniveauet, men det er givet, at markedsværdiniveauet ligger meget højt, hvilket de indirekte statistiske indikatorer viser. Der vil da skabes »falsk social værdi « i denne sektor og i dens leverandørbrancher, altså kunne realiseres ekstraprofitter, der ikke er produceret dér. Dette virker afgørende ind på betingelserne for totalreproduktionen.

Som eksempel på SIII har jeg valgt bygge- anlægssektoren og som dens leverandørbrancher dem, der i statistikken figurerer som henholdsvis »stenler- og glasindustri« og »træ- og møbelindustri«. Valget er afhængigt af de tilgængelige statistikker og af den politiske rolle bygge- anlægssektoren spiller ved at være afgørende for formerne for arbejdskraftens reproduktion og ved at indgå i produktionen af fast kapital. At tage byggeanlægssektorerne som eksempel på SIII indebærer et brud med kriterierne for sektoropdelingen i Marx' reproduktionsskemaer, hvor den ifølge sin stoflige funktion i reproduktionsprocessen skulle høre under både sektor I og sektor II. Men valoriseringsperspektivet er i Marx' teori overordnet det stoflige perspektiv, afgørende bliver altså bygge- anlægssektorens rolle for den totale valoriseringsproces; og her må den ifølge sin financeringsform udskilles som en særlig sektor.

Valget af bygge-anlægssektoren som udtryk for SIII er dog problematisk af flere grunde:

For det første findes der i denne sektor en særlig form for profit, nemlig jordrenten, der indgår konstituerende i produktets pris. P.g.a. markedsværdiniveauets højde og permanens skabes der da både »falsk social værdi« 
indenfor produktion af boliger og anlæg, samtidig med at en af produktionsbetingelserne, jorden, i sin pris også indeholder den form for »falsk social værdi «, som Marx benævner »differentialrente «.

Det betyder, at der ved bygge- anlægssektorerne i selve produktionen både er tale om en profitform, der udspringer af et permanent overgennemsnitsligt profitrateniveau indenfor konkurrencens betingelser, og om en profitform, der gennem sit grundlag i monopolet på jord for en given gruppe mennesker konstitueres delvis udenfor konkurrencens betingelser.

Det bliver derfor nødvendigt kort at behandle problemet om jordrentens funktion indenfor byggeriet.

\subsection{Jordrenten og bygge- anlægssektoren.}

Ved bygge- anlægssektoren er produktion, cirkulation og distribution på punkter særegne i forhold til de $\varnothing$ vrige sektorer i samfundet. For det første må man indenfor bygge- anlægssektoren skelne mellem produktion, cirkulation og distribution af boliger, erhvervsejendomme, institutioner og anlæg. Produktionsprocessen er her relativt identisk med den der foregår indenfor de andre brancher i samfundet i alt fald hvad angår den sociale form, men cirkulationen og distributionen kræver inddragelsen af elementet »grundareal «. Det betyder selvfølgelig ikke, at man kan producere en etageejendom i den bare luft, men det betyder, at grundarealets valoriseringsformer kommer ind i forbindelse med cirkulationen og af distributionen af den kapital, der er blevet anvendt ved produktionen og af de varer, der kom ud af den.

Selve produktionsprocessen er her identisk med den vi finder i det $\emptyset$ vrige samfund med undtagelse af, at betingelserne for formindskelse af arbejdsmassen er mindre her end $i$ industrien. Hvis der ved produktionen er tale om en adskillelse af producent og bygherre så adskiller cirkulationsprocessen sig kun ved, at den er langt hurtigere end ved alle andre varer p.g.a. realkreditten, og fordi produktionen indenfor denne sektor i meget vidt omfang foregår ved bestilling. ${ }^{25}$ Her forudsatte vi at bygherren ejede grundarealet hvorpå han lod bygge. Har producenten eller entreprenøen derimod ejet dette areal, så karakteriseres cirkulationen af det forhold, at der gennem den skal foregå en valorisering, der gør valoriseringen af den til grundarealopkøbet anvendte kapital mulig. (Vi forudsætter her, at entreprenør og grundejer kun i sjældne tilfælde falder sammen). Der vil da i cirkulationen indgå kravet om reproduktionen af den kapitaliserede jordrente. (se fremme).

Det er primært produktionen af boliger, erhvervsbygninger, institutioner og anlæg jeg tænker på, når jeg udvikler tesen om at der skabes »falsk social værdi« indenfor boligsektoren. Thi begrebet »falsk social værdi« - som det er udviklet her - er ikke systematisk adskilt fra de præmisser, der regulerer

25. Grue, ibd. s. 11. 
konkurrencens begreb, det beror altså hverken på monopol på jord eller i stoflige skranker for produktforøgelse- som det er tilfældet med de betingelser, som skaber jordrenten indenfor landbrugssektoren.

Karakteren af en prisstigning indenfor bygge- anlægsproduktionen er muliggjort af både værdiproduktionens og værdirealiseringens forøgelse. Altså muliggjort af den høje arbejdsintensitet indenfor byggeriet, - der ikke er slet så udtalt i forbindelse med anlægsarbejder - reperationsarbejdets store rolle her, og vanskelighederne med at rationalisere arbejdet på de store byggepladser.

I modsætning til de brancher, der leverer varer til byggeanlægssektoren, beror prisstigningerne her altså ikke udelukkende på »falsk social værdi«, men værdien, der tvinger priserne i vejret i forhold til resten af samfundet er til en vis grad produceret. På den anden side giver den forøgende anvendelse af betonelementer, der er præfabrikerede, og dermed af ufaglært arbejde indenfor byggeanlægssektoren mulighed for en stigende organisk kapitalsammensætning. Hertil kommer kravet til teknik ved bygningen af større fabriksanlæg, hospitaler, brokonstruktioner, tunneler og vejnet. Byggeanlægssektoren er altså ikke bare en arbejdsintensiv sektor med små og mindre virksomheder.

Det er vigtigt at afgøre om man kan tale om jordrente i egentlig forstand indenfor bygge- anlægssektoren. Det drejer sig her på den ene side om den absolutte jordrentes eksistens på den anden side om eksistensen af differentialrenterne.

Hvori består den absolutte jordrente?

Den består i det forhold, at den institutionelt (gennem monopolet på jord) og stofligt (gennem frugtbarhedsgrader) givne skranke for produktforøgelse indenfor landbruget skaber muligheder for at realisere produktet til en produceret værdi, der ligger over produktionsprisniveauet i resten af samfundet.

At byggeriet er mere arbejdsintensivt end resten af samfundet har intet at gøre med jordens karakter, det har derimod noget at gøre med byggeriets stoflige forudsætninger: at byggemodning f.eks. er afhængigt af meget arbejde i forhold til konstant kapital og at meget byggeri også er det. Problemet er altså: findes der i byggeanlægssektoren nogen skranker for kapitaltilførsel af institutionel eller stoflig art?

Svaret må blive bekræftende, fordi der findes afgørende institutionelle muligheder for at holde jord tilbage fra bebyggelse, der ikke kan sælges til en pris, der når den indgår i produktet fra denne sektor indeholder både jordrente og gennemsnitsprofit, altså gør realiseringen af produktet gennem salg eller leje muligt til en markedsværdi der ligger over gennemsnitttet indenfor industrien. At der er tale om »absolut jordrente « indenfor bygge- anlægssektoren fremgår klart af det forhold, at kun de jorde byggemodnes, der gennem salg eller leje kan give en pris, der indeholder både renter af den til grundkøbet anvendte kapital og den ved bebygningen af jorden fremskudte. (At jorden har en minimumspris betyder selvfølgelig ikke, at al jord må sælges, når det kan afkaste denne pris. Det er netop princippet ved al spekulation i jord at vente lidt længere). 
Kerneindholdet af begrebet »absolut jordrente « er, at dets forudsætninger er en begrænsning af kapitalbevægelsernes frihed og dermed af en gennemsnitslig udbudsmaksimering (som den findes indenfor industrien ved en given minimumsprofit). Disse forhold genfindes indenfor byggeriet.

Grundarealets værdi bestemmes altså - såfremt det er et jomfrueligt grundareal - af kapitaliseringen af den laveste rente som gør salg eller udleje af jord mulig til byggeformål: Indeholder grundarealet egenskaber, der er produkt af arbejde eller resultat af beliggenhed, kommer dets prisbestemmelse til at afhænge af kapitaliseringen af differentialrenten. Der er nemlig også tale om differentialrenter i forbindelse med bygge- anlægssektoren.

Differentialrente I er den ekstraprofit, der udspringer af lige store grundstykkers - med samme kapitalapparat - forskellige beliggenhed. Denne differentialrente kan tydeligvis konstateres $\mathrm{i}$ huslejen eller prisen på grundarealer modnet $\mathrm{i}$ lige høj grad, men med forskellig beliggenhed (og samme størrelse) indenfor en storbys areal f.eks. ${ }^{26}$ Det samme gælder differentialrente II, der angiver ekstraprofitter på lige store jorde med samme beliggenhed men med forskellige kapitalanlæg.

Her er dog tale om forskelle på bolig- erhvervs- og offentligt byggeri. For det første gælder det, at den absolutte jordrente blokerer for bygningen af boliger, der ved leje eller salg ikke kan give gennemsnitsprofitraten (som den findes i industrien) plus en ekstraprofit svarende til renten eller den kapitaliserede rente af grundarealets »værdi «. For det andet vil kun de virksomheder kunne opføres, hvis produktion vil kunne medvirke til at give en ekstraprofit gennem en forøgelse af produktiviteten. Privatejendommen på jord til fabriksog forretningsbebyggelse virker altså direkte blokerende på kapitalanlæg af industriel og handelsmæssig karakter.

Her findes dog den særegenhed hos offentligt byggeri og byggeri financeret af de almennyttige boligselskaber at udlejningspriserne er bestemt at omkostnings- og renteforholdene på den enkelte ejendoms opførelsestidspunkt og at stat og kommune kan stille grundareal til rådighed for sådant byggeri på helt andre betingelser end jord kan inddrages i det private byggeri. ${ }^{27}$

Hertil kommer at »erfaringerne fra mellemkrigstiden viser, at en række udlejere - især af mindre ejendomme i provinsen - undlader at benytte mulighederne for huslejeforhøjelser fuldt ud. $\ll^{28}$

Og endelig at huslejeloftet for den ældre boligmasse op til 1975 har skabt et prishieraki i boligmassen, der betyder, at det nye boligbyggeri kan give anledning til enorme priser og permanente ekstraprofitter. At der findes en overgennemsnitlig profitrate i nybyggeri i forhold til resten af samfundet siger Grue lige ud:29

26. Se Helga Fassbinder: Preisbildung, Monopol und Spekulation beim städischen Boden. Prokla, nr. 10, 1973.

27. Grue, ibd. s. 157.

28. Grue, ibd. s. 156.

29. Grue, ibd. s. 157. 
»Teoretisk bestemmes det nye boligbyggeris omfang under fri prisdannelse således, at der opnås samme forrentning af den investerede kapital i boligbyggeriet som ved andre investeringer. Tilpasningen foregår imidlertid så langsomt, at den teoretiske ligevægt kun sjældent nås. Selv under fri prisdannelse på boligmarkedet vil der være en ufuldkommen lejetilpasning i det eksisterende byggeri. I nybyggeriet vil en overnormal forrentning af den investerede kapital føre til en forøgelse af boligproduktionen. Da byggekapaciteten imidlertid er meget beskeden i forhold til boligbestanden, vil der i en årrække kunne opnås en unormal høj afkastning af investeringen i nyt boligbyggeri«.

Man skal her ikke lade sig narre af det forhold, at huslejelovgivningen forhindrer dannelsen af en enhedspris per $\mathrm{m}^{2}$ indenfor byggeriet: differentialrenterne eksisterer alligevel, således forstået, at det er den dårligst beliggende og modnede jord, der lægger minimumsprisen per $\mathrm{m}^{2}$. Ekstraprofitterne (differentialrenterne) kommer altså til udtryk som faktiske prisforskelle per $\mathrm{m}^{2}$, men det $g \varnothing r$ ingen forskel fra differentialrentedannelsen indenfor landbruget, hvor ekstraprofitterne jo opstår på baggrund af en enhedspris på byg, rug, etc. Der er ligefuldt tale om realiseringen af »falsk social værdi «. Eksistensen af huslejelovgivningen, hvor en del af befolkningen kan få tilfredsstillet deres krav til lejligheds- størrelse og kvalitet, beliggenhed og fasciliteter til en pris langt under den, der betales for den samme mængde $\mathrm{m}^{2}$ i nybyggeriet accentuerer kun differentialrenterne og den absolutte jordrente ved at presse jordens salgs- og lejeværdi i vejret. (Renten er her årsag, salgs- og lejeprisen virkning).

Hvor minimumsforskelle i udstyr og beliggenhed altså giver store differentialrenter i nybyggeriet har huslejelovgivningen sat eksistensen af differentialrenterne ud af kraft på beboelsesejendomme til udlejningsformål, der omfattes af huslejelovgivningens rammer; forhold, der bl.a. er søgt omgået gennem oprettelsen af ejerlejligheder. Men dette ophæver ikke differentialrentens latente eksistens, der viser sig så snart ejendommen kan udstedes til ejerlejligheder eller blot når den sælges. Huslejelovgivningen kan dog ikke forhindre at der i den omfattede boligmasse findes en svag differentialrente af typen II, hvor altså lejlighedernes udstyr har begrundet svage forskelle i huslejen på baggrund af den ældre boligmasses nybyggeripris.

Disse restriktioner findes ikke i forbindelse med erhvervsejendomme, og differentialrenterne og den absolutte jordrente fungerer her uden restriktioner.

Det er her givet at både profitterne indenfor erhvervsbyggeri, udlejning og indenfor nybyggeri af boliger, ikke er værdimæssigt dækket ind. Ved nybyggeriet, hvor efterspørgslen skruer priserne yderligere i vejret, er der ikke givet nogen maximumsgrænse for profitterne, mens minimumsgrænsen naturligvis er gennemsnitsprofitten i industrien plus rentesatsen på lånene til byggeriet.

Det er klart, at mulighederne for kapitaliseringen af differentialrenterne og den absolutte jordrente gennem de almene vurderinger spiller en væsentlig rolle for etableringen af et forklaringskraftigt inflationsbegreb. Muligheden for omprioritering $\mathrm{og}$ for optagelsen af nye lån giver anledning til at en stor prissum kan fungere i samfundet uden at være dækket ind gennem vardiproduktion. 
Hvad enten denne masse er udstedt dækningsløst af staten eller skaffet gennem lån, så belaster den prisniveauet i samfundet ved at skrue efterspørgslen hårdt op og dermed muliggøre en lavere produktivitet i brancherne, og det slår tilbage på nationens position på verdensmarkedet og dermed igen på de internationale lånemuligheder. Staten viser sig her atter i sine interventionsformer ulykkeligt spiddet mellem hensynet til visse vælgergrupper (i dens boligpolitik) og hensynet til handels- og betalingsbalancen (og dermed til nogle andre vælgergrupper). Oveni kommer de muligheder der findes for at regulere boligmarkedet: obligationsop$\mathrm{k} \emptyset \mathrm{b}$ og -salg, byggerationering, diskontoregulering - disse muligheder er relativt virkningsløse. Naturligvis kan noget af den værdi, der udtrykker den realiserede differentialrente, i deltilfælde forklares gennem merværdi i pengeform anvendt som rentekapital, men på totalsamfundsmæssigt plan er differentialrente jo per definition netop det over gennemsnitsprofitten overskydende. Dette overskydende kan da næppe forklares som dækket ind af ekstraprofitten, altså som en størrelse, der realiseres gennem totalmerværdimassen.

\subsection{Bygge- anlægssektorens nøjere bestemmelser: Produktionens karakter.}

Bygge- anlægssektorens produktionsresultat havde i 1970 en værdi af cirka 18 milliarder kroner svarende til 14\% af bruttofaktorindkomsten. Denne sektor indtager altså en fremtrædende plads i samfundsøkonomien. Det betyder at prisniveauet her vil have afgørende indflydelse på hele samfundet, fordi bygge- anlægssektorens produkt både indgår i arbejdskraftens reproduktion og i udgifterne til en stor del af den faste kapital, samt til skabelsen af de almene produktionsbetingelser. For det følgende er det vigtigt at understrege, at bygge- anlægssektoren er et udpræget hjemmemarkedserhverv..$^{30} » \mathrm{På}$ grund af produktionens karakter er det i høj grad afskærmet fra udenlandsk konkurrence (i 1967 blev kun 1 promille af den samlede tilgang af bygge- og anlægsinvesteringer dækket af import.) Den yder intet bidrag til eksporten ${ }^{31}$ At bidraget til eksporten er meget ringe og kun gælder for særdeles få varearter bekræftes af skemaet »Danmarks udenrigshandel med materialer til bygningsbrug 1950-1958« bag i Grues bog »Byggevirksomheden og den $\varnothing$ konomiske udvikling $\ll$.

Det er altså afgørende for markedsværdiniveauets konstans indenfor byggeanlægssektoren, at det ikke tvinges ned af udenlandsk konkurrence på hjemmemarkedet og af kravet om lav produktionspris, der svarer til afsætningsbetingelserne på verdensmarkedet.

30. Peter Wendt: Byggeri og boligforhold. København 1973, trykt i serien Erhverv og samfund, red. af S. A. Hansen. s. 15.

31. Wendt, ibd. s. 15. 
»Den særlige prisudvikling for bygge- anlægssektorens produktion og den deraf direkte eller indirekte afledede stigning i boligtjenesteprisen (og antageligt også i prisen på bygnings- og anlægstjenester i øvrigt), som har fundet sted i 1960'erne, hænger sammen med sektorens beskyttelse mod international konkurrence. Indtægtsstigninger i resten af samfundet og den tilskyndelse til boligforbrug, som ligger i de direkte og indirekte subsidieringsordninger, har resulteret $\mathrm{i}$ et vedvarende efterspørgselspres efter sektorens produktionsresultat i det meste af ti-året. Presset har givet sig udslag i en vækst i faktoraflønningerne, der langt fra er modsvaret af produktivitetsfremskridt.« ${ }^{32}$

Ikke engang bygge-anlægssektorens hovedleverandører er underkastet udenlandsk konkurrence på hjemmemarkedet på linie med andre ernhverv. Importkvoten for disse brancher er kun $9 \%$ mod $12 \%$ i resten af samfundet. ${ }^{33}$ Og Wendt mener at denne kvote snarere er faldet siden $1970 .{ }^{34}$ Anlægsaktivitetens muligheder for at bestemmes ad politisk vej har gjort udviklingen i denne del af sektoren mest stabil.

»Man kan derfor ikke for bygge- og anlægsvirksomheden - således som for den almindelige industrielle fremstillingsvirksomhed - tale om markeds $\varnothing$ konomiske drivkræfter. Bygge- og anlægssektoren er i meget væsentligt omfang en politisk styret virksomhed, og denne styring har i tidens løb været anvendt til ikke blot at fremme (eller hæmme) de egentlige bygningsmæssige formål, men også til at regulere den almindelige økonomiske udvikling med henblik på at tilvejebringe samfundsøkonomisk balance. $\ll^{35}$

Det første problem, der i forbindelse med bestemmelsen af prisniveauets årsager i denne sektor må behandles er spørgsmålet om bygge- anlægssektorens arbejdsintensive karakter.

Følgende faktorer giver bygge- og anlægssektoren en arbejdsintensivitet over gennemsnittet: ${ }^{36}$ For det første består en stor del af denne sektor af reperationsarbejde, der er meget vanskeligt at rationalisere gennem indførelsen af konstant kapital. For det andet er bygge- anlægssektoren af flere årsager ikke udviklet teknisk med samme homogenitet og intensitet som det er tilfældet $\mathrm{i}$ industrien. Grue anfører at byggetiden i årene efter 1945 har taget til p.g.a. mangelen på industriel organisering af arbejdet på de stadigt voksende byggepladser. ${ }^{37}$ Nørby anfører, at leverancesystemet for byggeriet er overordentligt desorganiseret, når undtages det såkaldte $»$ totalentreprisesystem $\ll .{ }^{38}$ Den konstant stigende efterspørgsel og den manglende konkurrence fra og på verdensmarkedet har medvirket til at muliggøre den fortsatte eksistens af en række mindre firmaer i byg-

32. Wendt, ibd. s. 15-16.

33. Wendt, ibd. s. 15, Viggo Nørby: Rationalisering indenfor bygge- og anlægsvirksomheden, trykt i Strukturproblemer i Erhvervslivet, red. af H. Winding Pedersen og Kjeld Scherfig, i serien Studier fra Københavns Universitets Økonomiske Institut, nr. 18 s. 102.

34. Wendt, ibd. s. 15 , note 1 .

35. Nørby, ibd. s. 102.

36. Nils Groes: Kapitalbehov i forskellige erhverv og Peter Bjerregaard og Jarn Schauby: Det samlede kapitalbehov i de private erhverv, trykt i Kapital og Produktion, Forhold og perspektiver for erhvervene i Danmark, red. af Nils Groes, København 1975, s. 253 og 337. Se også PPII, s. 149.

37. Grue, ibd. s. 14.

38. Nørby, ibd. s. 100-101. 
geanlægssektoren. Et uelastisk akkordsystem kan også have været medvirkende til at lade den producerede værdimasse forblive stabil.

Alle disse forhold kan ved konstant merværdirate virke således, at den producerede merværdimasse ikke falder så stærkt i bygge- anlægssektorerne som i resten af samfundet, fordi den indfører et lavere organisk kapitalsammensætnings-gennemsnit; (hvilket ikke udelukker en række virksomheder med et for det samfundsmæssige gennemsnit meget højt sammensætningsniveau). Men disse forhold kan ikke forklare de kraftige prisstigninger i sektoren og tilvæksten i nyværdien.

Dette bekræftes at de rationaliseringerne og kapitalintensiveringen i denne sektor, der trods deres heterogenitet har været udbredt indenfor de seneste år.

For det første foregår $60 \%$ af det nye boligbyggeri v.hj. af præfabrikerede materialer og ufaglært arbejdskraft. ${ }^{39}$ Wendt anslår arbejdskraftforbruget ved industrialiseret byggearbejde til at være 4-5 gange lavere end ved traditionelt byggeri. ${ }^{40}$ Herved kommer omkostningerne ved traditionelt byggeri op på 50\% mere end ved montagebyggeri. ${ }^{41}$ Det gælder her, at byggeri af etageejendomme er meget mere industrialiseret end byggeri af enfamilieshuse og produktionsprisen per $\mathrm{m}^{2}$ følgeligt betydeligt lavere ${ }^{42}$ - et forhold, der tilsløres af at udlejningsprisen ikke bestemmes af den billigste $\mathrm{m}^{2}$-pris, men af den $\mathrm{m}^{2}$-pris, der svarer til den laveste produktivitet i byggesektoren.

Ifølge Tiårsoversigten 1975 er det primært arbejdslønnen, der har hævet byggeriomkostningerne fra 1968 til 1972 for muret etagebyggeri, enfamilieshuse og for en montagebygget ejendom. Prisen på materialer stiger samlet fra 1968 til 1972 med 25\% mens prisen på arbejdskraften (lønnen) stiger med 43\%. Men arbejdslønnens stigning indikerer her ikke ansættelse af flere arbejdere, altså ingen absolut stigning i merværdimassen ved konstant m'. Fra 10/6 1969 til 14/11 1972 sker der et absolut fald i totalantallet af arbejdere og arbejdende mestre ved privat og offentlig bygge- anlægsvirksomhed. ${ }^{43}$

Derimod udgør materiale- og varekøbet i regnskabsoplysningerne for bygge- anlægssektoren en noget større post end lønudgifterne. I 1972 gik 7.931.4 mill. kr. til materialer mod 5.337. o. mill. kr. til lønninger. ${ }^{44}$ Hertil kommer at reperationsarbejdets andel af den samlede byggeanlægsaktivitet er faldende. I 1958 udgjorde de 1/4 af investeringerne i sektoren. I 1969 1/10.45

Nørby anfører, at hvor nybyggeriet i $\mathrm{m}^{2}$ er steget fra 2,7 mill. i 1950 til 9 mill. i 1969 (altså en stigning på mere end 300\%), så er antallet af beskæfti-

39. Nørby, ibd. s. 104. Grue, ibd. s. 18-19.

40. Wendt, ibd. s. 61.

41. Wendt, ibd. s. 62.

42. Tiårsoversigten, 1975, s. 20.

43. Statistisk Årbog, 1971: s. 126-127. Statistisk Årbog 1974, s. 120-121.

44. Statistisk Årbog, 1975, s. 122-123.

45. Wendt, ibd. s. 45. 
gede ved bygge- anlægsvirksomhed kun steget knap 30\%, og her falder den væsentligste stigning på ufaglærte. ${ }^{46}$ Forbruget af arbejde er desuden faldet per $\mathrm{m}^{2}$ : ca. 24 timer per $\mathrm{m}^{2}$ i 1951 mod 19 timer i 1961 og 11 timer i $1964 .{ }^{47}$ Alligevel må Nørby konstatere:

»Mens produktionen per beskæftiget på byggepladsen er steget stærkt som følge af den foretagne rationalisering, kan samme gunstige resultater ikke afløses i prisudviklingen. Det må konstateres, at prisudviklingen i det industrialiserede byggeri har fulgt samme opadgående linie som priserne $\mathrm{i}$ det traditionelt fremstillede. Der er flere årsager hertil: det stærke efterspørgselspres og begrænset konkurrence har i alle led gjort det muligt at beregne sig rigelige fortjenstmarginaler. Det industrialiserede byggeri kræver en stor kapitaludrustning, der har nødvendiggjort store - og måske for store - afskrivninger. Endelig har man i byggeriet i vid udstrækning benyttet indvundne besparelser til kvalitetsforbedringer - bedre teknisk udrustning, fællesforanstaltninger og lign., som ikke umiddelbart kan aflæses af den foreliggende statistik. $\ll^{48}$

Vi må altså slutte, at markedsværdiniveauet indenfor bygge- anlægssektoren gør realiseringen af en langt større værdi mulig end der faktisk er produceret dér.

Denne opfattelse bekræftes også af tallene for virksomhedssammensætningen indenfor bygge- anlægssektoren. I anlægssektoren er kaptalintensiteten ${ }^{49}$ størst, her er den organiske sammensætning højest. I byggeriet svinger kapitalintensiteten, men den højeste investeringsstigning i samfundet fra 1960 til 1972 findes indenfor byggefagene..$^{50}$ Den højeste kapitalsammensætning indenfor bygge- anlægssektoren findes foruden ved anlægsvirksomheden også ved montagebyggeriet. Byggeriet af en-familieshuse og etageejendomme v.hj. af traditionelle byggemetoder (ringe grad af præfabrikation, udtalt anvendelse af faglært arbejdskraft) er det mindst kapitalintensive byggeri. ${ }^{51}$ Også fabriksbyggeriet er kapitalintensivt, det foregår oftest v.hj. af kombineret stål- og betonbyggeri med ringe anvendelse af arbejdskraft fra de traditionelle byggefag. Arbejdsformen ligner den, der anvendes ved bro- og viaduktbyggeri. Det samme gælder bygningen af militære anlæg for det offentlige. ${ }^{52}$ Institutionsbyggeriet derimod vil p.g.a. sin høje installationsstandard have større arbejdsintensitet, selvom dette byggeri også er meget kapitalintensivt.

Præfabrikationen af typehuse har også forøget kapitalens organiske sammensætning indenfor bygge- anlægssektoren stærkt. ${ }^{53}$

Ser man på statistikken over forøgelsen fra 1969 til 1971, så viser det sig at stigningen i virksomhedsantallet i bygge- anlægssektoren er 5\%, men indenfor ka-

46. Nørby, ibd. s. 104.

47. Nørby, ibd. s. 105.

48. Nørby, ibd. s. 105.

49. Kapitalintensitet er et gradsudtryk, der i borgerlig terminologi angiver størrelsen af investeringerne i fast kapital og i råstoffer. Arbejdsintensitet angiver graden af arbejdstimeantal udgivet ved en given produktmasse, angiver altså værdiindhold.

50. Groes, ibd. s. 256.

51. Wendt, ibd. s. 62.

52. Grue, ibd. s. 27.

53. Groes, ibd. s. 257. 
tegorien »fremstillingsvirksomhed « kun $1 \%$. I brancherne sten-, ler- og glasindustri og træ- og møbelindustri er stigningen henholdsvis $7 \%$ og $1 \%$ for samme periode. ${ }^{54}$

Tager vi tabellen for bestand, tilgang og afgang af momsregistrerede virksomheder i 1971 ser vi, at afgangen i bygge- anlægssektoren i forhold til totalbestanden var 9\%, tilgangen $11 \%$. De samme størrelser for fremstillingsvirksomhed var: $10 \%$ og 9\%, altså en større afgang og en mindre tilgang end i bygge- anlægssektoren. For detailhandelen var tallene: $11 \%$ og $10 \%$. For transportvirksomhed: $12 \%$ og $12 \%$.

Kapitalens voldsomt heterogene anbringelse indenfor bygge- anlægssektoren bekræfter tesen om, at det høje regulerende markedsværdiniveau svarer til de individuelle værdier for en række små og uproduktive virksomheder, men at der samtidig findes en række store og højproduktive virksomheder indenfor branchen.

Entreprenørfirmaerne, der udgør de store virksomheder indenfor bygge- anlægssektoren, er gennemgående større end virksomhederne indenfor andre brancher. ${ }^{55}$

Fra 1971 til 1974 sker der følgende bevægelser i virksomhedsantallet indenfor bygge- anlægssektoren: ${ }^{56}$

\begin{tabular}{|c|c|c|c|c|c|c|}
\hline Antal ar & 2 & $5-6$ & $10-19$ & $50-99$ & $100-499$ & $500-$ \\
\hline Årstal & 7174 & 7174 & 7174 & 7174 & 7174 & 7174 \\
\hline Ent & 2477 & $80 \quad 240$ & 99206 & 8573 & 7461 & \\
\hline & 49 & 712618 & 4523 & 6649 & 232 & 3 \\
\hline & 26901 & 662661 & 356362 & $23 \quad 24$ & 117 & \\
\hline & & & & & & \\
\hline & 270228 & $124 \quad 175$ & 1151 & $12 \quad 17$ & & \\
\hline & 852760 & 308231 & 154136 & 1010 & & \\
\hline $\begin{array}{l}\text { Blikke } \\
\text { mestre }\end{array}$ & 764629 & $507 \quad 409$ & 244215 & 611 & 7 & \\
\hline
\end{tabular}

Udviklingslinien er her tydeligt, at de helt små firmaer er forøget indenfor alle brancher i sektoren. At entreprenørfirmaerne er forøget i alle størrelseskategorier, men at de større håndværksfirmaer er faldet $\mathrm{i}$ antal. Dette tyder på de $\emptyset$ gede krav om kapitalintensitetkrav som entreprenørfirmaerne p.g.a. produktionens form: montagebyggeriet, lettest kan opfylde.

Den procentvise stigning i antallet af momsregistrerede virksomheder fra 1971 til 1972 indenfor bygge-anlægsvirksomhed og fremstillingsvirksomhed ved følgende kategorier af afgiftsangivet omsætning forholder sig således: ${ }^{57}$

54. Statistisk Årbog, 1974, s. 114-115.

55. Wendt, ibd. s. 49.

56. Statistisk Årbog, 1974, s. 118-119. Statistisk Årbog 1975, s. 122-123.

57. Statistisk Årbog 1974, s. 112-113. Statistisk Årbog 1975, s. 114-115. 
Stigning i antallet af momsregistrerede virksomheder fra 1971 til 1972 i \%.

\begin{tabular}{|l|c|c|c|c|c|}
\hline $\begin{array}{l}\text { Firmaom- } \\
\text { sætning }\end{array}$ & $0-49.999$ & $\begin{array}{c}50.000- \\
99.999\end{array}$ & $\begin{array}{c}2,5-2,9 \\
\text { millioner }\end{array}$ & $\begin{array}{c}5-9,9 \\
\text { millioner }\end{array}$ & $\begin{array}{c}10 \text { mil- } \\
\text { lioner }\end{array}$ \\
\hline $\begin{array}{l}\text { Bygge- og } \\
\text { anlægsvirk- } \\
\text { somhed }\end{array}$ & -8 & -1 & 22 & 6 & 11 \\
$\begin{array}{l}\text { Fremstil- } \\
\text { lingsvirk- } \\
\text { somhed }\end{array}$ & -6 & -3 & 6 & 13 & 4 \\
\hline
\end{tabular}

I kategorierne 0-49,999 kr. ligger bygge- anlægssektorens fald over fremstillingsvirksomhedens. I 50.000-99.999 kr-klassen ligger byggeanlægssektorens fald under fremstillingsvirksomhedens. Derimod stiger antallet af virksomheder i de større omsætningsklasser betydeligt mere for byggeanlægssektoren end for fremstillingsvirksomhed. Af tabel 111 og 113 i Statistisk Årbog fra 1974 viser det sig, at entreprenørfirmaerne udgør $8 \%$ af det samlede firmaantal, men har $47 \%$ af omsætningen og råder over $40 \%$ af de beskæftigede i bygge-anlægssektoren. Sammenlignet med murer- og tømrermestre ser forholdet således ud:

\begin{tabular}{|l|c|c|c|c|}
\hline$\%$ & Firmaantal & $\begin{array}{c}\text { Beskæf- } \\
\text { tigelse }\end{array}$ & Omsætning & $\begin{array}{c}\text { Bruttoind- } \\
\text { tjening }\end{array}$ \\
\hline Entreprenører & 8 & 40 & 47 & 46 \\
Murermestre & 21 & 23 & 18 & 19 \\
Tømrermestre & 19 & 12 & 11 & 11 \\
\hline
\end{tabular}

Entreprenørfirmaerne spiller altså en afgørende rolle indenfor byggeanlægssektoren.

Hertil kommer, at produktivitetsudviklingen generelt søges fremmet for hele byggeriet gennem særlige støtteordninger, der indeholder skranker for lav-produktive virksomheder. ${ }^{58}$

Der er altså belæg for den her fremførte tese om at det er et stort antal lavproduktive virksomheder, der regulerer markedsværdiniveauet inden for SIII, men at det er de store virksomheder, der realiserer ekstraprofitter og dermed påfører samfundet en stor masse »falsk social værdi «. Herved bringes den konstante og variable kapital i resten af samfundet til at stige og profitraterne formindskes da relativt $\mathrm{i}$ forhold til profitrateniveauet i bygge- anlægssektoren. Det permanent høje markedsværdiniveau og dermed realiseringen af permanente ekstraprofitter er kun mulig indenfor bygge- anlægssektoren p.g.a. efterspørgslens og udbuddets karakter:

58. Nørby, ibd. s. 102-104. 
Efterspфrgslen i bygge- anlagssektoren:

Efterspørgslen skabes af følgende faktorer:

I) Offentlige anlæg. Udgør $1 / 4$ af sektorens produktværdi. ${ }^{59}$

II) Erhvervsbyggeri. Ca. 25\% af det færdiggjorte boligareal lå i 1970 i erhvervsejendomme $.^{60} 39,9 \%$ af industriens investeringer i 1970 gik til byggeri. ${ }^{61}$

III) Offentligt erhvervsbyggeri.

IV) Privat etagebyggeri.

V) Privat parcelhusbyggeri. Post IV og V udgjorde $2 / 3$ af alt boligbyggeri i $1970 .{ }^{62}$

VI) Offentligt institutionsbyggeri.

VII) Reperation og vedligeholdelse.

I 1968 og 1972 gik henholdsvis 13\% og 14\% til bygge- anlægsarbejder og $14 \%$ og $13 \%$ til maskiner, transportmidler mv. af de faste bruttoinvesteringer. ${ }^{63}$

$2 / 3$ af det færdiggjorte boligbyggeri i 1970 var opført af private uden offentlig støtte. Hovedparten af den resterende trediedel var opført af boligselskaber ${ }^{64}$ Resten af stat og kommune. Offentligt boligbyggeri voksede fra 1958 til 1970 med $12 \%$ årligt, det private med $10 \%{ }^{65}$

Staten spiller altså en stigende rolle ved efterspørgslen her. Ved det private erhvervsbyggeri spiller konjunkturerne afgørende ind. Efterspørgslens permanente stigning ud over udbuddet skyldes dog også fundamentale strukturændringer og politiske beslutninger: Overførslen af arbejdskraft fra land til by har făet boligbehovet til at eskalere. Udvidelsen af uddannelserne, socialvæsenet, etc, og etableringen af en omfattende infrastruktur har skruet efterspørgslen til byggeanlægssektoren op på et hidtil ukendt plan. Hertil kommer huslejeloftet i den ældre boligmasse, der har skabt et enormt pres på nybyggeriet. Også realkreditreguleringens overgang til den private sfære i 1958 har fået byggeriet til at stige.

Bygge- anlægssektoren er en sektor, hvor efterspørgslen kan forøges og formindskes politisk, men statens muligheder for at formindske den er mindre end dens muligheder for at forøge den. Byggerationering, rentepolitik, stop for offentligt byggeri er midler i statens hænder, men disse kan ikke skabe den konkurrencesituation i bygge- anlægssektoren, der alene kan presse pris- og aktivitetsniveauet ned.

Udbyddet i bygge- anlagssektoren:

Udbuddet har vi behandlet i det foregående, her skal blot foretages en systematisk rubricering af dets faktorer:

59. Wendt, ibd. s. 15.

60. Wendt, ibd. s. 54.

61. Groes, ibd. s. 322. (beløbet angives i faste priser.)

62. Wendt, ibd. s. 53.

63. Tiårsoversigten, 1975, s. 84. Beløbet er angivet i årets priser.

64. Wendt, ibd s. 53.

65. Wendt, ibd. s. 54-55. 
I) Udbuddet stiger indenfor bygge- anlægssektoren gennem en stor tilgang af både mindre og meget store kapitaler.

II) Udbuddet skifter karakter i retning af montage-byggeri og typehusproduktion.

III) Udbuddet kan ikke dække efterspørgslen på boliger p.g.a. den af differentialrenten oppressede jordpris i byområder, der giver alt for høje leje- og købspriser; og p.g.a. den for langsomme vækst i boligantallet i forhold til væksten i boligforbrugende grupper.

IV) Importen spiller en minimal rolle. Det samme gør konkurrencen på verdensmarkedet gennem eksport.

V) Bygge- anlægssektorens særlige lånemuligheder har gjort en meget stor produktion mulig, men har samtidig begrænset denne til sådanne typer af produktion, der har kunnet afkaste en profit, der både har kunnet dække en gennemsnitsprofit plus jordrente plus renteudgifter til lån. Endelig er det private byggeri blevet inspireret til på trods af prisniveauet gennem skattefordele at forøge reallønnen: et stigende antal lønmodtagere har erhvervet egen bolig.

Afgørende for hele vores problematik er det, at udbuddet ikke har kunnet påvirke markedsværdiniveauet i nedadgående retning, at konkurrencens begreb synes at modificeres i denne sektor.

Virkningerne af en sådan sektor på totalreproduktionen er overordentlig negativ, da den indgår konstituerende for både konstant og variabel kapital og dermed kan hæve omkostningsprisen afgørende, og sænke reallønnen for visse lønmodtagergrupper.

Som den borgerlige $\varnothing$ konomi har erkendt skaber dette sociale uroligheder og vanskeligheder for den nationale kapital på verdensmarkedet. Ikke alene realiseringen af differentialrentesummen gennem lån i fast ejendom og gennem jord- og ejendomshandel belaster $\emptyset$ konomien ved at realisere enorme prissummer, der ikke er dækket ind gennem en produktion af brugs- og bytteværdi; men også virkningen på industriens omkostningsniveau og på reallønnen skaber skævheder i totalreproduktionen, fordi kapitalisterne i de ramte brancher søger at kompensere for prisstigningerne på konstant kapital gennem prisstigninger og rationaliseringer i arbejdsprocessen, og fordi lønmodtagerne reagerer med kravet om højere løn og bedre arbejdsbetingelser.

Endelig skal pengene til at realisere den »falske sociale værdi i denne sektor skaffes et eller andet sted fra, og dermed belastes betalingsbalancen og hele det nationale kreditsystem.

\subsection{Valoriseringsbetingelserne i bygge-anlægssektorens hovedleverandør- brancher}

Bygge- anlægssektoren er ikke ene om at have et overgennemsnitsligt markedsværdi- og profitrateniveau. De to brancheklynger, der leverer hovedparten af 
bygge-anlægssektorens varer er hvad angår efterspørgselsog konkurrencebetingelserne næsten lige så privilegerede. Det drejer sig om de brancheklynger, der i industristatistiken hedder »sten- ler og glasindustri $\ll$ og »træ- og møbelindustri«. I det følgende optræder de under forkortelserne STI og TRI. (»I« refererer til deres status af sektor I brancher, brancher altså, der leverer varer til at udgøre den konstante kapital).

Disse brancheklynger udmærker sig ved at være afgørende bestemt af væksten indenfor sektor III, og dermed indirekte af den statslige efterspørgsel. I det følgende skal jeg gennem opridsningen af en række indikatorer vise, at markedsværdiniveauet ligger højere i disse brancheklynger end i resten af samfundet (når undtages bygge- anlægssektoren), ja at de ligger næsten på linie med bygge-anlægssektoren (når der tages højde for de stoflige forskelligheder i produktionsprocessen) hvad angår profitrateniveau og at der også i disse brancheklynger skabes »falsk social værdi«, fordi der over et længere tidsrum ikke dannes en produktionspris, at gennemsnitsprofitrateniveauet altså ikke trænger igennem her.

A) Importen er ringe for STI- og TRI-varernes vedkommende. Importkvoten udgjorde for rå- og hjælpestoffer plus tjenester kun 9\% (af sektorens samlede produktionsværdi) i 1958 mod $12 \%$ for alle andre brancher under ét. ${ }^{66}$ Wendt anfører også, at den formodentligt snarere er faldet siden dengang. ${ }^{67}$ Importen af varer til byggeriet er beskeden, den udgør kun 5-6\% af den samlede import. ${ }^{68}$ Konkurrencen for STI og TRI på hjemmemarkedet fra fremmede firmaer er altså relativ svag og kan ikke i samme grad som ved andre brancher tvinge markedsværdien nedad gennem en forøgelse af udbuddet eller gennem kvalitetskonkurrence.

Således har STI den højeste \%-del indenfor industrisektoren af hjemmemarkedet i forhold til den del, der dækkes af importerede varer, nemlig 74,9\% i 1969, hvor gennemsnittet er 39,7\%. TRI har 37,7\% af hjemmemarkedsomsætningen indenfor denne branche på danske virksomheders hænder. Denne brancheklynge er altså i langt højere grad end TRI udsat for konkurrence,hvilket da også viser sig i indikatorerne for udviklingen indenfor de to klynger. ${ }^{69}$

Også hvad angår eksporten er STI mindre udsat for konkurrence end TRI. Eksporten i \% af produceret værdi er i 1965 for STI 11\% mens den er 18\% for TRI. Det er for STI's vedkommende især eksporten af cement, der har været faldende. For TRI's vedkommende består $64 \%$ af eksporten af møbler. ${ }^{70}$

66. Wendt, ibd. s. 15. Der er tale om bygge-anlægssektorens samlede produktværdi.

67. Wendt,ibd. s. 15 , note 1 .

68. Grue, ibd. s. 169.

69. S. A. Hansen, Industri og håndværk, udgivet i serien Erhverv og Samfund, red. af S. Å. Hansen, København 1972, s. 60.

70. S.Å. Hansen, ibd. s. 58-59. 
B) Virksomhedsantal og virksomhedsstørrelse indenfor STI og TRI viser også, at der er tale om en række mindre virksomheder med relativt lav produktivitet samt en række store og meget store virksomheder med høj produktivitet.

»Den kemiske industri og sten, -ler- og glasindustrien er kendetegnet ved, at stordriften er fremherskende indenfor nogle specielle industrigrene, medens virksomhederne $\mathrm{i}$ andre brancher har en meget ringe gennemsnitsstørrelse. $\ll^{71}$

Og »Træ- og møbelindustrien består i overvejende grad af mindre virksomheder. Indenfor papir- og grafisk industri er der tale om typisk stordrift... «22

Virksomhedsfordelingen i de to brancheklynger ser således ud:

Virksomhedsantallet $i \%$ af totalvirksomhedsantallet fordelt på virksomhedsstørrelser efter antallet af ansatte. ${ }^{73}$

\begin{tabular}{|l|c|c|c|}
\hline Antal ansatte & $10-19$ & $50-99$ & $500-99$ \\
\hline STI & 34 & & 0,7 \\
TRI & 39 & 8 & 0,3 \\
Kemisk industri & 26 & 19 & 3 \\
Tekstilindustri & 27 & 15 & 0,2 \\
Næringsmiddelindustri & 24 & 15 & 0,8 \\
Jern- og metalindustri & 33 & 12 & 0,3 \\
\hline
\end{tabular}

Det er tydeligt, at både STI og TRI er stort repræsenteret blandt de små virksomheder, og at STI er godt repræsenteret blandt de større.

C) At prisniveauet og prisstigningerne i disse brancheklynger ligger over gennemsnittet er hævet over enhver tvivl:

Varditilvaksten i \% af produktvardien. 1971, udvalgte brancher ${ }^{74}$

\begin{tabular}{|l|l|}
\hline STI & 66 \\
TRI & 52 \\
Kemisk industri & 45 \\
Tekstilindustri & 46 \\
Næringsmiddelindustri & 26 \\
Jern- og metalindustri & 53 \\
\hline
\end{tabular}

71. S.Å. Hansen, ibd. s. 26.

72. S.A. Hansen, ibd. s. 26.

73. Statistisk Årbog.

74. Statistisk Årbog 1974, s. 126. 
Stigninger i værditilvæksten for i alt fald STI følger af følgende skema, der angiver kvantum- og værdibevægelser indenfor industrien fra 1970 til 1971:

\begin{tabular}{|l|c|r|r|r|r|r|}
\hline & \multicolumn{2}{|c|}{} & \multicolumn{2}{c|}{$\begin{array}{c}\text { Totalprodukt- } \\
\text { massen }\end{array}$} & \multicolumn{2}{c|}{ Totalværdien } \\
\hline & $\begin{array}{c}\text { total- } \\
\text { produkt }\end{array}$ & $\begin{array}{c}\text { total- } \\
\text { værdi }\end{array}$ & udførsel & $\begin{array}{c}\text { ind- } \\
\text { førsel }\end{array}$ & udførsel & $\begin{array}{c}\text { indfør- } \\
\text { sel }\end{array}$ \\
\hline STI & 3 & 424 & 51 & 11 & 1 & -14 \\
TRI & -1 & 19 & 15 & -14 & 2 & 2 \\
Kemisk industri & -1 & 562 & 1 & 3 & 7 & 1 \\
Tekstilindustri & 1 & 74 & 31 & 18 & 3 & 1 \\
Transportindustri & 13 & 457 & -15 & -18 & 9 & -25 \\
\hline
\end{tabular}

I STI falder indførselsværdien, men dets kvantum stiger, værdistigninger i denne branche er altså ikke forårsaget af stigninger i importpriserne. Udførselskvantummet fra STI og TRI stiger, mens udførselsværdien stiger meget lidt. Det kan tyde på stigende materialeintensitet og produktivitet i de to brancher.

Hertil kommer yderligere et indeks for vareværdierne: det drejer sig her om en sammenligning mellem stigningen i kvantum sammenholdt med stigningen i værdi for visse varegrupper fra 1968 til 1973. ${ }^{75}$ Disse tal bliver dog mangelfulde, da der ikke findes nogen mængdeangivelser for TRI og kun relativt få for STI:

\begin{tabular}{|lcr|}
\hline & Kvantum & Værdi \\
\hline Cement & $26 \%$ & $83 \%$ \\
Varer af asbestcement & $26 \%$ & $82 \%$ \\
Ildfaste sten, blokke & $-5 \%$ & $18 \%$ \\
Fliser og lign. & $26 \%$ & $54 \%$ \\
Tagsten & $16 \%$ & $74 \%$ \\
Molersten & $60 \%$ & $66 \%$ \\
Isoleringsglas af flere lag glas & $255 \%$ & $303 \%$ \\
Planglas, trukket, ufarvet & & \\
\hline
\end{tabular}

Sammenligner vi disse tal med tal for stigninger i kvantum og værdi indenfor andre brancher ser vi, at produktivitetsstigningerne slet ikke er fulgt af så stærke værdistigninger som i STI:

75. Statistisk Årbog, Statistisk Årbog 1971 og 1974. 


\begin{tabular}{|l|c|c|}
\hline & Kvantum & Værdi \\
\hline Blyakkumulatorer og startbatterier & $29 \%$ & $59 \%$ \\
Konservesdåser & $40 \%$ & $74 \%$ \\
Klare lakker, pigment lakker & $28 \%$ & $35 \%$ \\
Sæbe & $5 \%$ & $27 \%$ \\
Papirmasse & $9 \%$ & $15 \%$ \\
Gulvtæpper & $48 \%(1969)$ & $43 \%$ \\
Tråd af kobber & $9 \%$ & $-8 \%$ \\
Tegnebøger, punge, mapper af læder & $63 \%$ & $41 \%$ \\
\hline
\end{tabular}

Markedsværdiniveauet synes altså at ligge noget over andre brancher i STI.

D) Det er nu vigtigt at vise, at prisniveauets højde (værditilvæksten) i STI og delvis i TRI, for så vidt pris- og profitniveauet på punkter også her ligger over gennemsnittet, ikke skyldes, at disse brancheklynger er arbejdsintensive ud over det almindelige. Det højere markedsværdi- og profitrateniveau skyldes altså ikke at der produceres meget mere værdi her end $\mathrm{i}$ andre brancher, men at der realiseres mere.

Allerede det forhold, at der findes en lang række kapitalintensive, store firmaer i disse klynger tyder på, at værditilvæksten ikke skal søges i lav organisk sammensætning alene. Men også indikatorer på kapitalintensiteten i forhold til arbejdskraftmassen i disse klynger bekræfter tesen:

Variabel kapital og afskrivninger $i \%$ af totalomsatningen. Udvalgte brancher. ${ }^{76}$

\begin{tabular}{|l|c|c|c|}
\hline & Variabel kapital & \multicolumn{2}{|c|}{ Afskrivninger } \\
\hline år & 1972 & 1967 & 1972 \\
\hline STI & 29 & 7 & 7 \\
TRI & 27 & 3 & 3 \\
Næringsmiddelindustri & 14 & 2 & 2 \\
Tekstilindustri & 28 & 4 & 3 \\
Kemisk industri & 21 & 4 & 4 \\
Jern- og metalindustri & 31 & 3 & 3 \\
\hline
\end{tabular}

STI og TRI er altså ikke mere arbejdsintensive end gennemsnittet af brancher. Hvor TRI's kapitalintensitet ligger på gennemsnittet af branchernes, ligger STI's åbenbart betydeligt over resten af branchernes.

76. Statistisk Årbog, industriens regnskaber. 
Den større værditilvækst må altså søges i andre forhold end produceret værdi. Endelig kan det også vises, at der ingen entydig sammenhæng er mellem stigninger i arbejdstimetallet og værditilvæksten indenfor brancherne: ${ }^{77}$

Stigning $i$ antallet af udførte arbejdstimer og varditilvaksten minus løn $i \%$ fra 1971 til 1972.

\begin{tabular}{|l|r|r|}
\hline STI & 1 & 8 \\
TRI & 5 & 2 \\
Kemisk industri & 1 & -6 \\
Næringsmiddelindustri & -3 & 5 \\
Tekstilindustri & -3 & -1 \\
Jern- og metalindustri & 1 & 7 \\
\hline
\end{tabular}

Dette bekræfter altså heller ikke, at værditilvæksten skulle skyldes produktion indenfor klyngerne TRI og STI.

Endelig bekræfter indikatorerne på profitraterne i industriens afdelinger, at værditilvæksten i STI og TRI ikke kan skyldes »overført« værdi fra flydende kapital - desuden fraregnes denne post netop ved den statistiske bestemmelse af begrebet »værditilvækst $\ll:^{78}$

Bruttoindtjening $i \%$ af totalomkostninger.

\begin{tabular}{|l|r|r|c|}
\hline år & 1967 & 1970 & 1972 \\
\hline STI & 17 & 18 & 16 \\
TRI & 9 & 10 & 11 \\
Næringsmiddelindustri & 7 & 7 & 7 \\
Kemisk industri & 10 & 10 & 8 \\
Jern- og metalindustri & 9 & 9 & 8 \\
Transportindustri & 3 & -2 & - \\
\hline
\end{tabular}

E) Tilbage bliver at argumentere for, at det heller ikke er lønstigninger, der forøger værditilvæksten så ekstraordinært i de to klynger. Allerede profitrateniveauet viser jo at det vanskeligt kan være rene lønstigninger der tæller så tungt i værditilvæksten, men andre indikatorer findes:

Skulle lønstigningerne på værditeoriens præmisser kunne forklare værditilvæksten, så skulle det ske gennem en fremhævelse af en forøget værdiproduktion på baggrund af en konstant eller labil merværdirate.

77. Tiårsoversigten 1975, s. 28.

78. Tiårsoversigten 1971, Statistisk Årbog 1974 og 1975. 
$\mathrm{Nu}$ har vi allerede set, at stigninger i arbejdstimetallet ikke viser nogen direkte sammenhæng med udsvingene i værditilvæksten. Derimod er der en tydelig sammenhæng mellem værditilvækst og lønstigninger:

Løn-, vardi- og arbejdstimetilvakst i STI og TRI $i$ \% af forudgående år.

\begin{tabular}{|l|c|c|c|c|}
\hline år & 1965-1966 & $1967-1968$ & $1970-1971$ & $1971-1972$ \\
\hline Løntilvækst i STI & 10 & 5 & 13 & 13 \\
Værditilvækst i STI & 9 & 7 & 11 & 16 \\
Løntilvækst i TRI & 10 & 14 & 3 & 18 \\
Værditilvækst i TRI & 6 & 16 & 3 & 19 \\
Arbejdstimetilvækst & -4 & -6 & -2 & 1 \\
i STI & & & & \\
Arbejdstimetilvækst & -3 & 3 & -9 & 5 \\
i TRI & & & & \\
\hline
\end{tabular}

Vi har umiddelbart både lønstigninger og profitstigninger samtidig med at vi har fald i arbejdstimetallet, både absolut og relativt. Det opkaster et teoretisk problem ved hvis kerne denne artikel har villet røre: hvor kommer denne værditilvækst fra, når den ikke er produceret?

Svaret kunne her blive - som f.eks. Altvater og co. har villet set det i Probleme des Klassenkampf nr. 17/18, - at kapitalistklassen blot forhøjer priserne og derigennem henter profitterne hjem og bøder for deprecieringen af den konstante kapital. Men denne løsning er ukorrekt:

For det første ligger det i kapitalens begreb at maximere sit afkast så meget som muligt. Dette sker på konkurrencens niveau gennem en løsrivelse af priserne fra værdierne i de enkelte kapitalomslag og varemetamorfoser. Kapitalens begreb er her den struktur, der formidler mellem væsensplanet og fremtrædelsesdimensionen: værditeorien kan ikke forklare prisbevægelser, der kendetegnes af en adskkillelse af pris og værdi. Det kan princippet i kapitalens begreb derimod, thi her ligger den logik accentueret, at værdi og pris må afvige af hensyn til profitmaximeringen. Som det egentlig ligger implicit i hele Grundrisses fremstilling er profitmaximeringsloven, altså valoriseringsprincippet, det mest overordnede princip i hele den marxske videnskab om kapitalismen. Kapitalens profithunger er så stor, at selv værdiloven i øjeblikke må ophæves. Men denne ophævelse sker kun momentvist og kan aldrig være noget permanent, tendentielt eller principielt: hvor enkeltkapitaler og branchekapitaler over bare en kortere tid kan realisere enorme profitter, så forhindrer loven om dannelsen af produktionspriserne og gennemsnitsprofitraten at dette bliver noget permanent, og dermed at det bliver et generelt forklaringsprincip: prisstigningerne i kapitalismen kan godt forklares ved - $i$ alt fald som delmoment af en forklaring - at priserne sættes op $i$ alle brancher for at modvirke stigninger i omkostningsprisen. Men stigninger i profitten kan ikke forklares herigennem, fordi de hvis de gælder hele samfundet må være 
resultatet af enten et fald på sektor II's produktværdier, eller af et fald i reallønnen p.g.a. visse ændrede betingelser for klassekampen. Lokale stigninger i profitten af mere permanent karakter derimod er mulige på baggrund af en konstant merværdirate for hele samfundet, og indebærer realiseringen af en værdimasse, der ikke er produceret.

Marx belyser dette problem med al ønskelig klarhed i Theorien über den Mehrwert bd. II, s. 126-127. Han siger nemlig her, at kun den stigende markedsværdi i landbrugssektoren kan forklare landbrugsprisernes stigende prisniveau i begyndelsen af det 19-nde århundrede i England. I denne forbindelse afviser han følgende forklaringer på prisstigningerne:

»Det kan ikke forklares v.hj. af deprecieringen, thi det ville nok kunne forklare hvorfor industriprodukternes (priser) faldt ved større udvikling af produktiviteten indenfor industrien, altså hvorfor landbrugsprodukterne steg relativt i pris. Men det ville ikke kunne forklare hvorfor landbrugsprodukternes priser foruden denne relative stigning fortsat steg absolut. Ejheller kan det forklares ud fra profitratens fald. Thi denne ville aldrig kunne forklare en prisændring, men kun en aendring i fordelingen af værdien eller prisen mellem godsejer, kapitalist og arbejder«. (Min overs. OFK. Marx’ fremhævelser.)

Det er den sidste sætning, der er væsentlig her:

Marx' underforstår her, at merværdiraten er konstant, og hævder så, at prisstigninger som følge af den produktionspris, der skabes, hvis omkostningsprisen stiger og profitraten er konstant, er utænkelige, fordi de vil blive fulgt af lønstigninger - thi det ligger i det definitoriske udgangspunkt, der samtidig afspejler klassekampens spændingsforhold: merværdiratens konstans (over en given periode).

Selvfølgelig er netop pris-løn-spiralen et billede på klassekampens betingelser under kapitalismen, men den kan til syvende og sidst kun forklare profitterne som et resultat af en udhuling af reallønnen, og ikke som resultat af de handels- og finansmæssige forhold mellem nationerne på verdensmarkedet, og af forholdet mellem produktivitetsudvikling, udbud og efterspørgsel i brancherne i samfundet. Sådan en løsning må kort sagt focusere på de lønbegrænsende virkninger af indkomstpolitik især og kan ikke forstå statens andre og afgørende måder at intervenere i den kapitalistiske $\varnothing$ konomi på.

Anskuet på niveauet for konkurrencen og anskuet både på branche- og på totalplan er det tydeligt, at netop kapitalens væsen, dens profitmaksimeringstrang, udelukker profitstigninger på brancheplan, der er resultatet af en viljemaessig stigning i udsalgsprisen. Jeg mener her stigninger sat efter overvejelser og sat bevidst således, at prisen er opnået ved at der er lagt en langt større procent end gennemsnittet til omkostningsprisen.

Princippet for dannelsen af produktionspriserne og gennemsnitsprofitraten vil forhindre sådanne operationer ved at suge kapital til branchen og ved at de kapitaler, der anvender produktet fra de prisløbske brancher i deres produktion skifter til alternative produktionsmetoder, importerer eller yder pression ad anden vej.

Det betyder altså, at enhver mere permanent afvigelse fra gennemsnitsprofitraten besvares i formerne for reproduktion gennem boykotning af de dyrere produk- 
ter eller gennem kapitaltilførsel til sådanne profitfede brancher. Kun ad én vej kan denne proces blokeres og det dér via en instans, der står uden for totalreproduktionen ved ikke at være underkastet valoriseringsprincippet, kort sagt via staten.

Det er statens efterspørgselsskabende aktion der kan give grundlag for et midlertidigt stop i konkurrencens maskine, men det har frygtelige følger for den kapitalistiske økonomi, der er så sensibel overfor mangel på balance, p.g.a. produktionens klassestruktur.

\subsection{Inflation og omkostningsprisstigninger}

Der er stor rimelighed $\mathrm{i}$ at antage, at en af inflationens årsager er de relative prisstigninger i sektor III og i dens leverandørbrancher. Det er det manglende fald i markedsværdierne i sådanne sektorer og brancher, der bl.a. skruer priserne op. Dette manglende fald, der kommer til udtryk som en overgennemsnitslig prisstigning i forhold til andre branchers prisniveauer, er forårsaget af en efterspørgselssituation, der over en vis periode sætter konkurrencens mekanismer ud af kraft. Statsinterventionens negative følgevirkninger er altså bl.a. prisstigninger i visse brancher og dermed ulige udviklingsbetingelser for alle kapitaler.

Men det manglende fald i markedsværdierne i sektor III og dens leverandørbrancher og dermed skabelsen af »falsk social værdi«i samfundet er kun en af flere årsager til inflationen. Følgende årsager skal yderligere behandles på baggrund af konkurrencens begreb:

I) Råvareprisstigninger, stigninger på fast kapital og branchespecifikke lønstigninger: disse stigninger udgør alle en stigning i enkeltkapitalens omkostningspris. Virkningerne på profitmassen afhænger af branchens konkurrencesituation. Hvis efterspørgslen er stærk nok vil profitraten kunne holdes relativt stabil, fordi markedsværdiniveauet kan øges. Ellers vil - ved labil eller faldende efterspørgsel - de prisstigninger være umulige, der ville kunne sikre en konstant profitmasse. Konkurrencen vil altså her resultere i et undergennemsnitsligt profitrateniveau indtil det - af denne årsag - faldende udbud (p.g.a. kapitalafvandring) skaber en efterspørgselskvote, der gør en gennemsnitsprofit mulig. Problemet er her, hvad der sker hvis efterspørgslen er så stærk, at de prisstigninger der skal justere profitraten til det nye omkostningsniveau, således at profitmassen forbliver stabil, er mulige som et mere permanent fænomen? Hvis altså brancheproduktet indgår som et helt uundværligt moment $i$ en hel række branchers produktionsproces - som det f.eks. er tilfældet med olieprodukterne?

Permanente prisstigninger her vil enten skabe:

a) et lavere profitrateniveau i en hel række brancher indenfor en eller flere nationers rammer, hvis der ikke er mulighed for alternative råvarer, maskiner eller specialuddannet arbejdskraft; eller

b) prisstigninger, der holder profitraten stabil, men skaber masser af »falsk social værdi «, der skal hentes gennem statslig underbudgettering, lån i udlandet, reallønsfald, etc.; eller 
c) prisstigninger, der er dækket ind gennem en øget merværdirate, der altså kræver faldende realløn eller/og forøget intensivering af arbejdet, forlængelse af arbejdsdagen, etc.

Alle disse virkninger er farlige for roen på arbejdsmarkedet og dermed for »borgfreden « mellem klasserne.

Det væsentlige forhold her er især prisstigninger på råvarer forårsaget af monopol-stillinger omkring udbuddet, af stoflige grænser for mekanisering af produktionen af råvarer, eller af direkte mangel på udvindelsesmuligheder. Råstoffernes fordyrelse gennem 70-ernes første halvdel har givetvis været en medvirkende årsag ved inflationsraten.

II) En anden faktor, der givetvis er medvirkende ved inflationen er følgende: De markedsdominerende virksomheder indenfor en branche kan kompensere for værdiforringelser af den konstante kapital gennem prisforhøjelser. Værdiforringelsen sker gennem forældelse af en given produktionsteknik (moralsk værdiforringelse), når en mere produktiv teknik bringes på markedet. Når den nye teknik har nået en sådan udbredelse, at dens produktivitets-forøgende virkninger begynder at påvirke udbuddet i en eller flere brancher, så vil den afgørende bestemme markedsværdiniveauet (ved at sænke det) og dermed bestemme mængden af det samfundsmæssigt nødvendige arbejde, der indgår ved produktionen af produktet. Den gamle teknik må så enten udskiftes omgående eller dens anskaffelsesværdi, der ikke længere kan reproduceres gennem salget af produktet til den nye markedsværdi fordi dens omkostningspris er for lav til formidle de gamle produktionsmidlers værdi over et givet (kort) tidsrum, må blive en delvis negativ post på virksomhedens regnskab, altså et aftræk i profitmassen.

Værdiforringelsen af den konstante kapital kan også ske ved at efterspørgslen falder og den påfølgende indskrænkning i udbuddet gennem en indskrænkning af den enkelte virksomheds produktion medfører, at den realiserbare produktværdi ikke kan formidle den til reproduktionen af den konstante kapital nødvendige værdimasse.

Det første tilfælde er der næppe nogen løsning på for den individuelle kapital eller for branchekapitalen i det hele taget.

Det andet tilfælde indebærer løsningsmuligheder, hvis produktionskoefficienterne er tilstrækkeligt fleksible således at en del af den konstante kapital kan omlægges til anden produktion.

Generelt vil virksomhederne imødegå denne situation ved at bremse produktmængden eller ved at sænke priserne alt efter de konkurrencebetingelser der handles under. I brancher med fă og dominerende firmaer vil det nok være en indskrænkning af produktmængden ved stabile eler stigende priser, der vælges. I brancher med stærk konkurrence vil priskrigen nok blive resultatet. ${ }^{79}$ Problemet

79. Wygodski: Der gegenwärtige Kapitalismus. Pahl Rugenstein, 1972. 
er her, hvilke grænser der findes for prisfastsættelse med henblik på realiseringen af en værdimasse, der dækker værdiforringelsen af den konstante kapital ind? ${ }^{80}$

Wygodski har underkastet konkurrencepolitikken hos de store firmaer en grundig undersøgelse og finder, at overvindelsen af værdiforringelser sker gennem indefrysningen af produktivitetsfremmende teknik, således at markedsværdiniveauet holdes tilstrækkeligt højt til at ekstraprofitmassen kan dække værdiforringelsen. Men denne løsning indebærer for det første, at de store firmaer indenfor og mellem brancherne ikke lader det mulige produktivitetsniveau blive til virkelighed, men finder dets virkeliggørelse hos mindre firmaer og kvæler det gennem indlemmelse. ${ }^{81}$ For det andet indebærer det, at der findes svære forhindringer for tilgang til branchen for fremmed kapital.

Problematikken her kan ikke løses gennem en henvisning til en stigende efterspørgsel på branchen, fordi stigende efterspørgsel ikke er en faktor, der primært er afhængig af branchen selv. Om virksomheden eller branchekapitalen derimod er herre over udbuddet afhænger af mange faktorer: råstofleverancernes strukturering spiller en rolle, produktivitetsniveauet er også afgørende. Kan leverancerne monopoliseres og er produktivitetsniveau og know-how-niveau så højt, at minimumsgrænsen for kapitalanlæg ligger i toppen, og er markedet vanskeligt tilgængeligt for nye produkter, så vil en prispolitik, der udspringer af en kunsig begrænsning af udbuddet være mulig, og således at der i markedsværdiniveauet er indbygget en ekstraprofitmasse, der er stor nok til at dække en gennemsnitsprofit eller en overgennemsnitslig profit plus værdiforringelsen. Men alene niveauet for den organiske kapitalsammensætning indebærer her, at markedsværdiniveauet ikke kan være dækket ind af produceret værdi, - hvilket derimod er Wygodskis tese. Der er nemlig også her tale om realiseringen af »falsk social værdi« $i$ form af ekstraprofitter, og problemet om reproduktionen af den moralske værdiforringelse gennem salg ved et givet markedsværdiniveau er egentligt kun spørgsmålet om fordelingen af ekstraprofitten på forskellige poster, (og mere eller mindre af hensyn til de forskellige fradragsregler - hvis vi ser helt konkret på det).

Sagen er vel nok den, at udbudsbegrænsningen m.h. på opnåelse af et markedsværdiniveau, der gør meget store ekstraprofitter mulige, er en balanceakt, hvor overbalancen udgøres af et profitniveau, hvis størrelse får store kapitaler fra andre brancher til faktisk at vove springet og pelsen og søge ind i den pågældende branche alle risiki til trods.

Konklusionen må nok her blive, at den moralske værdiforringelse er aktuel i en mulig eller faktisk konkurrencesituation: den »mulige« konkurrencesituation er en relation mellem meget store firmaer indenfor en branche eller fra branche til branche, hvor de pågældende firmaer råder over største delen af

80. Altvater, Hoffmann, Künzel og Semmler: Inflation und Krise der Kapitalverwertung, Prokla nr. $17 / 18,1975$, s. $262-265$.

81. Wygodski, bd. kap. III. 
markedsandelen. Her vil tendensen kunne gå i retning af en borgfred, hvor man ikke konkurrerer på pris, men holder markedsværdiniveauet stabilt gennem en nedfrysning af de udbudsskabende innovationer. Man kører altså bevidst på underkapacitet. Men det betyder selvfølgelig ikke, at man nedfryser omkostningssænkende innovationer, men man fortsætter her den indbyrdes konkurrence, dog blot således, at de faktiske omkostningssænkninger ikke kan »ses « på markedsværdiniveauet, altså har en ren ekstraprofitmaksimerende effekt.

Den »faktiske « konkurrencesituation er en relation mellem store og små firmaer eller mellem små firmaer indenfor en branche. De mindre firmaer anvender teknikken til at sænke priserne (gennem forøget udbud) - om de så har udviklet teknikken selv eller ej. De helt store firmaer derimod kan i kraft af deres markedsandel og enorme kapacitet hurtigt vinde en eventuelt priskrig og herefter igen stabilisere markedsværdiniveauet på dets tidligere højde (eller endnu højere). Resultatet er dog her, at markedsværdiniveauet kan blive presset længere ned, hvis de mindre firmaer ikke er tilfreds med deres markedsandel og selv vil have ekstraprofitter, men grænsen for sænkningen af markedsværdiniveauet er sat af gennemsnitsprofitten plus værdiforringelsens omslagsprocent. Herigennem sløves konkurrencen, og branchens prisniveau bliver overgennemsnitsligt. Et forhold, der alt efter udbud-efterspørgselskonstellationen vil trække yderligere kapitaler til. Resultatet af de mulige foranstaltninger mod værdiforringelse af den konstante kapital gennem udbudsbegrænsede foranstaltninger er altså afhængig af udbud-efterspørgselsmekanismen, og af de specifikke forhindringer for kapitaltilførsel - der aldrig kan være institutionelle indenfor industrien. Men ved en efterspørgselsovervægt vil værdiforringelsesforholdet kunne presse markedsværdiniveauet yderligere op, fordi dette skal dække både en gennemsnitsprofit, ekstraprofit (for visse firmaers vedkommende) plus en del til reproduktion af værdiforringelsen. Forholdet forstærker altså den skabelse af »falsk social værdi« som statens efterspørgselsskabende interventionsaktivitet medførte. Men her gælder, at for at tale om »værdiforringelse « af konstant kapital kræves en »faktisk « konkurrencesituation, der kan indføre et lavere gennemsnit for værdien, der altså kan sænke den portion samfundsmæssigt nødvendigt arbeje, der indgår i varens produktion. Det kan kun effektueres gennem kvantitative og kvalitative ændringer i udbud og produktionsmetoder. Disse ændringer behøver dog ikke påvirke markedsværdiniveauet for at de kan have værdiforringende effekt, fordi de kan betinge uacceptable niveauforskelle i ekstraprofitter hos de store firmaer.

III) Hvilken rolle pengeformen og dermed kreditten spiller for prisniveauet og dermed for inflationen (og primært for skabelsen af gennemsnitsprofitraten) skal undersøges i del II.

Der er nu teoretisk og empirisk åbnet op for en placering af statsinterventionens virkningssammenhæng i form af efterspørgsel til sektor III i det reproduktive kredsløb under kapitalismens betingelser. Det bliver da muligt at stille det 
spørgsmål systematisk, hvordan statens efterspørgsel opstår, fungerer, altså indvirker på den kapitalistiske $\varnothing$ konomi, som den tegnes af modsigelserne mellem enkelt- og totalkapital, og hermed stille denne artikels hovedspørgsmål: hvad er grænserne for statsinterventionen, i dens subjektive og objektive aspekt?

Svaret er her, at staten gennem sin efterspørgselsskabende aktion blokerer for dannelsen af produktionspriser i hele samfundet og dermed sætter sig i modsætning til kapitalens begreb: at afkaste så meget værdi som muligt proportionalt med sin størrelse.

Pointen er da, at gennemsnitsprofitraten ikke altid kan skabes gennem kapitaloverførsler, bl.a. p.g.a. kapitalens træghed, når den findes $i$ form af fast kapital. Alternativet er her, at profitrateudligningen mellem alle brancher så fordres af kapitalgrupperne i de forfordelte brancher ad politisk vej. Da kapitalens organisationer herhjemme opfatter for nøje statsstøtte som nedbrydelse af de liberalistiske principper, så kan profitrateudligningen kun ske ad negativ vej: gennem en standsning af den aktivitet, der giver nogle sektorer og brancher et overgennemsnitsligt profitrateniveau. Kort sagt gennem stop for efterspørgslen til sektor III.

Sådan skal byggestoppet bl.a. også forstås. 


\section{Del II: Uddybning af konkurrencens niveau}

\section{Kapitel 4}

\section{Kapitalens formspecificeringer og reproduktionsske- maerne}

I denne del skal følgende forhold undersøges: Statens eferspørgsels- og udbudsskabende mekanismer med henblik på dannelsen af gennemsnitsprofitraten. Der argumenteres for det forhold, at prisniveauet i industrien er afgrænset af gennemsnitsprofitraten, der på sin side er båret af det gennemsnitlige profitniveau indenfor brancherne på de varer, hvis individuelle værdi svarer til markedsværdierne.

Det bliver på baggrund af dette perspektiv ikke muligt, at få store firmaer i højt mekaniserede brancher (brancher med meget høj grænse for minimumsanlæg) kan sætte deres prisniveau vilkårligt over længere tid. Således kan enhver voluntarisk »cost-push «-teori på forhånd afvises. ${ }^{1}$

Prisniveauet er begrænset opefter af gennemsnitsprofitraten i de andre brancher, hvilket indebærer, at et permanent eller blot relativt langvarigt overgennemsnitligt ekstraprofitniveau i en branche vil fremkalde investeringspres på denne branche, et pres, der p.gr. af kredittens elasticitet og gigantiske rammer ikke engang er begrænset af den skyhøje nedre grænse for anlæg af kapital i visse brancher. Focuseres skal statens medvirken ved dannelsen af gennemsnitsprofitraten, ikke alene som det i foregående kapitel er blevet belyst - i egenskab af en instans, der skaber et højt markedsværdiniveau og dermed store ekstraprofitter - men også som en instans, der direkte gennem egne investeringer og investeringssubsidier og indirekte gennem sin udvikling af teknik og videnskab (det sidste aspekt skal dog ikke tages op her) påvirker udbuddets kvalitet og kvantitet og dermed dannelsen af et alment prisniveau (produktionspriserne) og af gennemsnitsprofitraten. En nærmere bestemmelse af begrebet for totalreproduktionen er også nødvendig, og det sker gennem en samtænkning af konkurrencens begreb og reproduktionsskemaerne. ${ }^{2}$

1. En god beskrivelse af cost-push og demand-pull effekterne findes hos Olaf E. Dombrowsky: Zur Kritik bürgerlicher Infla tionstheorien, Prokla, nr. 17/18, 1975.

2. Et af de første forsøg herpå er Grossmanns i Die Wert-Preis-Transformation bei Marx und das Krisenproblem, trykt i Aufsätze zur Krisen theorie, Archiv sozialistischer Literatur, nr. 20, Frankfurt, 1971. Artiklens løsning på problemer - der er koncentreret omkring en kritik af Rosa Luxemburg - ligger dog relativt fjernt fra det løsningsforsøg, der oprulles her. 
Endelig skal dannelsen af interesser i samfundet belyses ud fra den differentiering i revenukilde-begrebet som kapitalens form-specificeringer på niveauet for kapitalen-i-dens-realitet skaber, altså ud fra forskellen mellem handels- og penge- og rentekapitalens rolle i totalreproduktionsprocessen. ${ }^{3}$ For en metodisk behandling af disse emner er en række ekskurser nødvendige - der er altså ikke blot tale om sidespring fra den egentlige fremstilling, men om væsentlige momenter til opbygningen af vores konklusion.

Da industrikapitalens formbestemmelser på niveauet-for-kapitalen-idens-realitet er blevet gennemgået i første del, er det rimeligt at tage fat på de andre kapital-former.

\subsection{Handelskapitalen og gennemsnitsprofitraten}

Det kapitalistiske samfund kendetegnes af distinktionen mellem produktionssfære og cirkulationssfære: dette kommer til udtryk som en mulig og ofte faktisk variation mellem varernes individuelle og samfundsmæssigt nødvendige indhold af abstrakt arbejde (værdi). Denne variation formidles gennem bremsningen eller blokeringen af varekredsløbet:

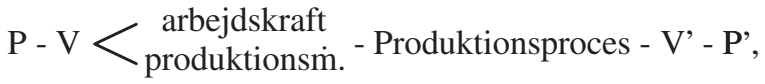

således at bevægelsen V' - P' ikke kan foregå. Der opstår da ofte en kompenserende bevægelse, der går ud på, at $\mathrm{P}$ forringes i forhold til den faktiske værdi af V'. Metamorfosen V' - P' får da en meget central rolle i kapitalismen. Det er gennem den at den producerede produktionsværdi realiseres uden en indskrænkning af værdiproduktet, dvs. således at gennemsnitsprofitraten kan realiseres gennem varesalget.

I den udviklede kapitalisme kan en særlig form for kapital udskilles til at varetage realiseringens funktion. ${ }^{4}$ Denne type kapital kaldes handelskapital (HK). Den afkaster ifølge sit væsen (qua kapital) profit på lige fod med de andre kapitaler i produktionssfæren, men da den tilhører cirkulationssfæren er den ikke selv med til at skabe det værdiprodukt, hvoraf profitten på totalsamfundsmæssigt plan skal tages. HK's aktivitet er bundet til pengekapitalens kredsløb og ser således ud: P-V-P'. ${ }^{5}$ De penge handelskapitalisten fremskyder må - ud fra tesen om en identitet mellem værdi og pris, der sætter sig igennem på totalplan og i tiden via cyklen - rent systematisk betragtet som en del af industrikapitalens (IK) værdiprodukt.

3. De illusioner, der udspringer omkring jordrenten, og som rubriceres under den trinitariske formel på linie med illusionerne omkring lønarbejde og kapital er ikke taget med her, bl.a. fordi de ikke spiller så stor en rolle ved forståelsen af statsintervention.

4. Denne kapitalform er for $\emptyset$ vrigt den genetisk første, mens den naturligvis logisk set er afhængig af industrikapitalen, hvor jo værdiproduktionens begreb betemmes.

5. Das Kapital, bd. III, s. 280. Se desuden Das Kapital, bd. III, kap. 16, 17 og 18. 
I IK's bevægelser indtræder HK via halv-metamorfosen P-V, og har således gennem den akt ikke gennemført varemetamorfosens hele gennemløb, dvs. at kun besidderen af vareproduktet har skiftet, mens vareproduktet selv ikke har gennemgået en formforvandling (til konsumtiv form). ${ }^{6}$

På niveauet-for-kapital-i-almenhed betragtes HK som uproduktiv, idet der pr. definition ikke kan skabes værdi i cirkulationssfæren, fordi arbejdet dér ikke har status af »konkret arbejde«, dvs. ikke er nødvendigt for at produktet kan få sin konsumerbare form. (Realiseringen af konsumtionens mulighed, ikke af dens virkelighed.) Således opfatter Marx f.eks. transportarbejde som produktivt arbejde, men ikke ekspeditionsarbejde i engros- og detailhandel. ${ }^{7}$

HK's fixe og cirkulerende kapital tærer altså ikke alene på det totale værdiprodukt i samfundet, men også på dettes stoflige side: den tærer på fonden af de »reproduktive « varer. ${ }^{8}$ HK består af tre typer kapitalanlæg:

a) HK til køb af IK's vareprodukt.

b) HK's faste kapitalanlæg (lagerbygninger, kontorer, etc.)

c) HK's lønarbejde. (Regning, bogføring, spedition, markedsføring, etc.) Salgsprisen for HK's vareprodukt, dets produktværdi, bliver da: $a+b+c+$ $(a+b+c+) \times$ gennemsnitsprofitraten).

Både $\mathrm{a}, \mathrm{b}$ og c plus profitten på dem er stoflige og værdimæssige størrelser, der er skabt af IK og blot nominelt overtaget af HK m.h. på tilegnelse af en del af totalmerværdien.

Efter hvilke kriterier, gennem hvilke form-bestemmelser, fordeles nu totalmerværdien skabt af IK på henholdsvis IK og HK? Marx' tese om dannelsen af gennemsnitsprofitraten må her modificeres derhen - hvilket han eksplicit fremhæver - at varerne realiseres til deres markedsværdier (HK's salgspris), at varerne altså realiseres til produktionspriser på totalplan. Dette indebærer, at IK's vareprodukt afhændes til en pris, der ligger under produktets markedsværdi (produktionspris). HK's profit indgår m.a.o. i dannelsen af produktionspriser, fordi HK's profit indgår i dannelsen af gennemsnitsprofitraten. ${ }^{9}$

Begrebet for dannelsen af gennemsnitsprofitraten giver tydelig en anvisning på hvilket omfang HK kan tage i forhold til den totale reproduktion: HK kan nemlig ikke overstige en sådan størrelse, at den tager en større profit hjem end IK. Dette ville nemlig betyde en kapitalflugt fra IK til HK. (Hvis omvendt så omvendt).

At HK's totalomfang bestemmer dens andel i gennemsnitsprofitraten er let at se: ${ }^{10}$ Totalkapitalen $(\mathrm{IK}+\mathrm{HK})=1000$. Heraf er IK $=900$ og $\mathrm{HK}=100$.

6. Her menes både produktiv og privat konsumtion.

7. Om »produktivt« versus »uproduktivt« arbejde se bl.a.: Theorien über den Mehrwert, bd. I, kap. 3 plus bilagene, samt Resultate des unmittelbaren Produktionsprozesses, Archiv sozialistischer Literatur, 17, Frankfurt, 1969, s. 64-74.

8. »Reproduktive varer « er varer, der er produceret i sektor I eller II, altså varer, der indgår som komponenter i den faste eller cirkulerende kapital.

9. Das Kapital, bd. III, s. 295-296.

10. ibd. s. 296-297. 
For IK er m' $=100 \%$, og v $=180, \mathrm{k}=720$. Merværdien hos IK er da $=180$. Disse 180 udgør samfundets totale værdiprodukt og skal deles mellem IK og HK proportionalt med deres størrelse. Da HK udgør 1/10 af totalkapitalen har den ret til $1 / 10$ af totalmerværdien $=18$. HK's p' bliver da $18 \%$. IK's profit er $9 / 10$ af $180=162$. P' er da som ved HK $=18 \%$.

Havde HK været større i forhold til totalkapitalen ville dens p' have overgået IK's.

IK sælger sine varer til HK for $720 \mathrm{k}+180 \mathrm{v}+162 \mathrm{p}=1062$. HK sælger dem videre med en profit på $18 \%$ af sin egenkapital $=100$, dvs. for $1062+18=$ 1080. Denne pris er varens produktionspris.

Marx slutter heraf, at HK's eksistens sænker produktionsprisen: merværdi 180 giver i forhold til en kapital på 900 20\% i gennemsnitsprofitrate, mens den i forhold til en kapital på 1000 kun giver 18\% i gennemsnitsprofit, og da produktionspriserne defineres som omkostningsprisen + omkostningsprisen multipliceret med gennemsnitsprofitraten, vil disse falde ved stigende HK og konstant værdiprodukt hos IK.

Heraf kan man bl.a. slutte følgende:

En sænkning af produktionspriserne betyder ikke en sænkning af markedsværdien, men blot en indskrænkning af IK's profit proportionalt med total-HK's størrelse, m.a.o. en sænkning af de priser HK betaler IK for dens vareprodukt.

Der er m.a.o. tale om en - fra enkeltkapitalside betragtet - åbenlys modsætning mellem IK's og HK's interesser.

Ifølge Marx har HK dog også gunstige virkninger på totalkapitalens omslag, fordi realiseringen af produktionsværdien overgår til en funktionalistisk instans, hvorved den totale kapital, der er involveret i realiseringen, vil kunne begrænses. Graden af HK's positive og negative virkninger på IK er altså bestemt af dens indvirkning på omslagshastigheden, der selvfølgelig til en vis grad er omvendt proportional med HK's størrelse (jo hurtigere omslag, jo mindre HK), i alt fald hvad angår post a), nemlig HK's udlæg til køb af IK's vareprodukt. ${ }^{11}$ Jo større en relativ del HK udgør i et samfund desto vanskeligere bliver det for produktivitetsstigninger at resultere $i$ et fald i produktionspriserne. Dels fordi HK's profit belaster IK's profitrate og forhindrer en reduktion af markedsværdiniveauet gennem udbudsfor $\varnothing$ gelse med samtidig prissænkelse, dels fordi HK's omfang og kvalitet medvirker til at selv de mindst produktive kapitaler kan få realiseret deres produktværdi, og dermed opretholde eksistensen.

Jo større anlæg til fix og cirkulerende kapital fra HK's side, desto større efterspørgsel i samfundet, fordi HK jo ikke selv skaber et vareprodukt, hvis form kunne bevirke, at det indgik reproduktivt i samfundet. HK indvirker da indirekte - da dens reproduktion og akkumulation begrænser den totale

11. ibd. s. 298 og s. 326 . 
reproduktions- og akkumulationsfond - til at forøge efterspørgslen len på SI- og SII-varer og dermed til at få markedsværdiniveauet til at stige.

En stor HK Indenfor et samfund medvirker da alt i alt - dens positive virkninger, der jo går ud på at den gennem en forøgelse af omslaget kan medvirke til en forøget merværdiproduktion, til trods - til at forværre dettes stilling på verdensmarkedet ved at forhøje dets produktionsprisniveau. ${ }^{12}$

Men en bedømmelse af HK's negative virkninger er bundet til muligheden for at afgøre størrelsen af realiseringsomkostningerne, hvis realiseringsfunktion blev varetaget af IK selv, og til muligheden for at afgøre HK's faktiske indvirkninger på omslagshastigheden, størrelser, der p.gr. af deres abstrakte karakter er vanskelig at arbejde med. Dertil kommer at markedsføringsmekanismernes store rolle i senkapitalismen for efterspørgslens opretholdelse kan give belæg for det kapitalrationelle i en relativt større HK end tilfældet var på Marx' tid. Men et er i hvert fald sikkert: HK's interesser er på totalplan entydigt bundet til IK's valoriseringsbetingelser, selvom det for den enkelte industri- og handelskapitalist ikke tager sig sådan ud.

Ser vi på den trinitariske formel, så er det tydeligt, at bevidstheden hos de to kapitalfraktioner, der udspringer af kapitalens formbestemmelse som henholdsvis IK og HK på niveauet-for-kapitalen-i-dens-realitet, umuliggør, at kapitalen opfattes som et ensidigt bestemt subjekt, der blot har den egenskab at afkaste profit proportionalt med sin størrelse. For profitten på IK er til en vis grad omvendt proportionalt med HK's størrelse (hvilket også - som vi skal se - er tilfældet med pengekapital og rentekapital).

At staten heller ikke betragter disse to kapitaltyper som ligestillede revenukilder viser bl.a. nationalbankens inddragelse af tilladelser til lån i udlandet m.h. på driftskreditter. ${ }^{13}$

For HK vil profitten naturligvis være omvendt proportional med det beløb der gives for en given masse varer fra IK. Profitten fremstår da snarere som resultatet af handelstalent, og HK som »produktiv«, end som et fast afkast på en given kapitalmasse proportionalt med dens størrelse. Men naturligvis fremstår profitten her også som »kapitalens frugt« og profitten som proportional med kapitalens størrelse, hvilket i forbindelse med HK sætter sig således igennem, at stigende kapitalmasse muliggør lavere produktværdi, simpelthen fordi omslagets hastigere tempo muliggør et større udbud. Men sådanne virkninger af stigende HK er ikke nødvendige, sammenhængene er derimod komplicerede og skal ikke bekandles yderligere her.

12. En intensivering af arbejdet under Handelskapitalen vil forøge kapitalens omslag på totalsamfundsmæssigt plan og dermed gøre et større værdiprodukt muligt. Samtidig muliggøres dog en udvidelse af Handelskapitalen, hvis indvirkning på gennemsnitsprofitraten vil være afhængig af stigningerne i Handelskapitalen i forhold til stigningerne i totalmerværdien. Se også Das Kapital, bd. III, s. 305-306 og s. 325-326.

13. Danmarks Nationalbank, beretning og regnskab, 1974, s. 81. 
Hvilke bevidsthedsformer HK giver anledning til er afhængig af det anskuende og agerende subjekts interesser, men differentieringen skulle blot fastslås.

\subsection{Kreditten og gennemsnitsprofitraten}

Til en forståelse af det objektive grundlag for dannelsen af gennemsnitsprofitraten, af formerne for statens integration med totalkapitalen og for en konkretere bestemmelse af de illusioner, som følger af kapitalens formbestemmelser på et konkretere niveau, er en behandling af kreditten nødvendig. Det niveau hvorpå kreditten skal afledes er både niveauet-for-kapital-i-almenhed og niveauet-for-kapitalen-i-dens-realitet. På niveauet-for-kapital-i-almenhed skal kreditten bestemmes ud fra den mulige bremsning eller blokering af varekapitalens metamorfose:

Kreditten skal her udledes af de følgende faktorer:

a) Pengenes funktion i cirkulationssfæren som på en gang kvantitativt udtryk for værdi (Mass der Werte) og pris-indeks (Massstab der Preise). I denne dobbeltfunktion ligger muligheden for inkonkurrens mellem værdi- og prisudtryk nemlig. ${ }^{14}$

b) oplagring af penge i form af skat (Schatz). Denne form må dog ikke sammenblandes med opbevaringen af likvide midler i kapitalismen, dvs. må ikke - som Keynes gør det i sit begreb »hoarding « - forveksles med pengenes funktioner i rentekapitalens form.

c) pengenes funktion som betalingsmiddel (Zahlungsmittel). Heri ligger den mulige adskillelse af varekapitalens kredsløb, således af varen er afhændet på et tidspunkt, hvor den endnu ikke er forvandlet til pengeform.

På niveauet-for-kapitalen-i-dens-realitet skal kreditten bestemmes ud fra følgende to funktioner:

A) Pengekapital i egenskab af akkumulationsfond.

B) Akkumulationsfondens størrelse i relation til akkumulationsbehovet under konkurrencens betingelser. ${ }^{15}$

Ad a) Dette punkt er den systematiske indfaldsvinkel til udledningen af papirpengene. Heri ligger den formmæssige mulighed for et brud i værdi og prisidentiteten over et vist tidsrum og på visse planer.

Men da kredittens hele væsen bestemmes på grundlag af værdiprisidentiteten - det viser Marx' overvejelser i kap. 17 af bd. II af Das Kapital, hvor akkumulationsfonden tænkes som kredittens grænser-kan værdipris-inkongruensen ikke være det bærende element $\mathrm{i}$ en bestemmelse af kredittens funktionsmåder. Således må man slutte, at selvom Bretton-Woods-aftalerne har ændret

14. Zur Kritik der politischen Ökonomie, Dietz Verlag, Berlin 1970, s. 67-68.

15. Theorien über den Mehrwert, bd. III, s. 508. 
begreberne for valutaernes gulddækning, så er det afgørende for valutaernes stilling stadig faktorer, hvis væsen udgøres af værdien, (se også forrige del).

Det betyder at værdi-pris-identiteten er dynamisk og sætter sig igennem ad mange veje, her især det forhold, at valutaternes købekraft er direkte proportionale med arbejdets produktivitet i den pågældende nation, men omvendt proportionale med produktionsprisniveauet.

Det er først og fremmest gennem handels- og betalingsbalancen, at værdipris-identiteten på nationalt og dermed internationalt plan gennemtvinges, fordi en kunstig skabt efterspørgsel f.eks. giver dækningsløs kreditudvidelse (»demand-pull-fænomenet), eller fordi en udvidelse af prisniveauet på SI- og/ eller SII-varer skruer produktionsprisniveauet yderligere op (»cost-push-fænomenet«), og følgelig kræver udvidelse af cirkulationsmassen.

Marx' tese om identiteten mellem værdi og pris er utænkelig uden det dynamiske aspekt som cyklus-begrebet bringer ind. Den er en dynamisk »lov«, der virker således, at den naturligvis ikke umuliggør en inkongruens mellem værdi og pris, men at den gennem virkningerne på totalproduktionen af en sådan inkongruens sætter rammer for dens mulige omfang. Således sætter identiteten af værdi-pris sig igennem i det stigende betalingsbalanceunderskud, hvor den i 30'erne satte sig igennem i en generel overproduktion, altså i en virkelig krise.

Den dynamiske identitet af værdi pris viser sig således idag i kravet om en bremsning af den offentlige og private konsumtion af hensyn til betalingsbalancen og til valutaens stilling. (For hvis der ikke var en dynamisk identitet mellem værdi og pris, så behøvede man jo ikke låne penge i udlandet, men kunne bare trykke dem selv). Således repræsenterer akkumulationen et værdiprodukt også når den muliggøres af penge hentet gennem lån i udlandske banker.

Ad b) Skat (Schatz) spiller idag ingen rolle for skabelsen af kreditfonden, fordi den er afløst af sine spejlbilleder i kapitalformen: penge- og rentekapital. I et kapitalistisk samfund kan penge ikke lægges til side som penge, fordi manglende merværdiafkast er det samme som tab.

Ad c) Pengenes funktion som betalingsmiddel er meget centralt, fordi det muliggør adskillelsen af køb og salg. I Theorien über den Mehrwert siger Marx om kapitalens funktioner i kredsløbet i egenskab af penge som betalingsmiddel: »Krisernes almene mulighed er kapitalens egen formmæssige forvandling, det at $\mathrm{k} \varnothing \mathrm{b}$ og salg tids- og rummæssigt falder fra hinanden. «16

Ad A) og B). I konkurrencen, hvor et givet markedsværdiniveau indenfor en branche, gennem de stoflige produktionsbetingelser det afspejler, sætter en minimumsgrænse for kapitalanlæg ved gennemsnitsprofit, vil kreditten spille en enorm rolle, fordi det er den, der gør akkumulationen uden akkumulationsfond mulig og dermed styrer de former hvorunder udbuddet kan udfoldes. Som sådan er kreditten en central faktor ved etableringen af gennemsnitsprofitraten

16. ibd. bd. II, s. 515. Min oversættelse, OFK. 
og produktionspriserne. Kreditten kan kun mangelfuldt udledes på niveauetfor-kapital-i-almenhed, fordi der dér nok findes begrebet for en akkumulationstvang, nemlig den, der kommer til udtryk i overgangen fra den absolutte til den relative merværdi og afspejler kapitalklassens reaktion mod det stignde lønniveau p.gr. af stigende beskæftigelse, en reaktion der kommer til udtryk i investering i fix kapital, men hvor det dog kun er forholdet mellem konstant og variabel kapital og mellem kapitalist- og arbejderklasse, der indeholder akkumulationstvangen, ikke forholdet mellem enkeltkapitalerne, hvor kapitalens væsen fuldendes. På konkurrencens niveau derimod (niveauet-for-kapitalen-idens-realitet) bestemmes akkumulationstvangen gennem markedsværdiniveauet: når det synker, stiger minimumsgrænsen for kapitalanlæg ved mindsteprofit og følgelig stiger behovet for en kredit, der ikke er begrænset af akkumulationsfondens rammer. (Akkumulationsfonden er den del af merværdien, der ikke konsumeres eller går til andre formål). Dette skyldes, at en række små og mindre kapitaler ikke realiserer profit nok til at have en akkumulationsfond i det hele taget. Kreditten i egenskab af en centralisering, fordeling og forøgelse af akkumuleret pengekapital til produktive formål spiller en enorm rolle for reproduktionens simple og udvidede former, fordi det er den, der gør bevarelsen af alle de mindre firmaer mulig gennem en stabilisering af udbuddet og gennem en muliggørelse af realiseringen af selv varer med en produktværdi, der ligger over det samfundsmæssigt nødvendige arbejde til denne vares produktion.

Kreditten gør også ekstraprofitterne mulige indenfor brancherne ved at formidle den omfordeling af akkumulationsfonderne, der gør den koncentration af kapital mulig, der alene kan virkeliggøre de helt store investeringer i kapitalanlæg. Hertil kommer desuden, at kapitalbevægelserne mellem brancherne, der jo gør gennemsnitsprofitraten mulig i det hele taget, er ganske afhængig af kreditten, fordi overflytningen af kapital fra en branche til en anden hvori profitniveauet er højere for større kapitaler f.eks. jo ikke kan ske før det oprindelige kapitalapparat er realiseret, hvilket kan være en meget langsommelig affære. Endelig er kreditten også en betingelse for den form for markedsf $\varnothing-$ ring, der karakteriserer hele typen af udbuds-efterspørgsel i senkapitalismen. Kredittens konkretere former kan afledes af henholdsvis vare- og pengeformen i kredsløbene:

I) Af vareformen følger den kommercielle kredit, leasing, vekselsystemet, kredit altså, der foregår uden mellemkomst af pengeformen.

II) Af pengeformen følger pengekapitalen, rentekapitalen, altså kreditformer, hvor kapital fremskydes som vare i egenskab af kapital. ${ }^{17}$

Disse former kan nok afledes også af varekapitalen, men det er først i pengeformen, at de får deres kapitalistiske form. Rente i form af naturalier er systematisk helt forskellig fra rente af kapital. Deres formfuldendelse er altså baseret

17. Das Kapital, bd. III, s. 416. 
på pengeformen. Marx anfører s. 496 af bd. III af Das Kapital, at kommerciel kredit ikke fuldkommen kan erstatte pengeformens kreditformer, fordi arbejdsløn og skat nøje er forbundet med pengeformen for i det hele taget at kunne eksistere, og fordi kun de færreste producenter kan sælge direkte til alle dem de er intresserede $i$ at $k \varnothing b e$ af.

Kreditten i pengeform og dermed pengekapital og rentekapital kan bestemmes ud fra følgende grundlag:

a) Akkumulationsfonds: fra egen fond $=$ selvfinancering, fra andres fonds $=$ rentekapital.

b) Revenuet. Både a) og b) formidles oftest via banker eller financeringsselskaber.

c) Vekseldiskontering, og salg af værdipapirer og faste værdier.

d) Lån i udlandet.

e) Statslån, eksportpræmier, financeringsstøtte, etc.

Punkterne c), d) og e) stammer altså ikke nødvendigvis fra merværdien, hvis vi anskuer en given nation som et lukket system. Men det er højst sandsynligt, at de lån der optages i udlandet er forsølvet merværdi skabt i dette land, og at de faste værdier er tidligere akkumuleret merværdi.

Det er nu væsentligt at stille sig spørgsmålet: hvilke rammer er der for kreditskabelsen, dvs. hvordan sådanne rammer - hvis de findes - sætter sig igennem?

Generelt må man sige: kreditskabelsen er begrænset til akkumulationsfonden for så vidt at den skal anvendes produktivt (som IK) og for så vidt at den skal erhverves på hjemmemarkedet og dér være udtryk for et forsølvet vareprodukt.

Tager vi derimod verdensmarkedet med i betragtning, er der kun den grænse for kredittens forøgelse, at den anvendes produktivt i en vis rate, dvs. at den ikke anvendes til privat og offentlig konsumtion. Men da der er stærke politiske hindringer for begrænsninger i disse to former for konsumtion ud over en vis ramme, kan kreditten i det moderne kapitalistiske samfund simpelthen ikke begrænses til produktiv anvendelse alene.

Men selv om kreditten kun ville blive anvendt reproduktivt og til akkumulation, så ville der også være grænser for sådan en anvendelse, fordi de andre nationer ville finde midler til at vægre sig imod et eller flere landes forspring i produktivitet. Anvendes kreditten derimod ikke-reproduktivt eller skabes den ved midler på hjemmemarkedet, der får den til at overskride akkumulationsfonden dér, så har det - som vi skal se - alvorlige virkninger for samfundet som helhed og for den interventionistiske stat i særdeleshed.

Lad os tage det sidste tilfælde først: forøgelsen af kreditten på nationalt plan langt ud over akkumulationsfonden. Magdoff og Sweezy påpeger i en interessant artikel fra februar 1975 i Monthly Review de utallige måder, hvorpå de private banker i USA kan skabe det Marx kalder for »fiktiv kapital«. Det er kapital, der ikke udtrykker forsølvingen af et værdiprodukt, men derimod blot det formelle krav på en del af totalmerværdien, altså på delagtighed i 
gennemsnitsprofitraten. Selvom Magdoffs og Sweezys konklusioner ikke er de samme som mine kan de påvisninger glimrende illustrere formerne, hvorunder kreditten på nationalt plan kan sprænge akkumulationsfondens rammer. Langtidslån via udstedelse af aktier - siger Magdoff og Sweezy - erstattes idag i stor udstrækning af kortfristede lån i de private banker, og der skelnes ikke mellem anlægs- og driftkapital. Især fra 1960 til 1974 stiger de kortfristede lån og det med en langt højere vækstrate end den, der gælder for den »ikkefinancielle« aktivitet i samfundet. Også bankernes spekulation af profithensyn stiger enormt i 70'erne: garantisummen i statsobligationer til dækning af udlånene plus egenkapital er forsvindende lille og formindskes stadig i forhold til udlånet. $80 \%$ af indlånene i bankerne i USA er udlånt, og op til $40 \%$ af disse indlån er ikke »rigtige « indlån, men lån taget i andre banker for at skaffe kapital. Bankerne udsteder også sælgelige beviser på indlån for at få kapital, m.a.o.: kreditten skabes ved hjælp af kredit.

Denne udvikling har givetvis både at gøre med Nixonregimets forkærlighed for Friedmanns kvantitetsteoretiske teorier om betingelser for $\emptyset$ konomisk vækst, men er selvfølgelig også nært forbundet med de enorme udgifter til imperialismens financering. Noget lignende kan ikke påvises herhjemme ved gennemgang af Beretning og regnskab for Danmarks Nationalbank, 1974, man har her helt kreditten i tømme, men en relativ stigning i de kortfristede kreditter er tydelig, samtidig med en stigning i kreditten til engros- og detailhandel i forhold til industrien. Kreditten til engros- og detailhandel fra 1963 til 1973 ser således ud:

Engroshandel: kreditstigning med 61\%. Detailhandel: 106\%. Industriens kredittagning: 79\%. (Tallene er givetvis blevet accentueret af krisen efter 1974).

Et andet udtryk for stigning i driftskreditterne gives i oversigten over industriens forskellige typer af lån i Carl Erik Sørensens »Kreditmarkedet og industriens ekspansion $\ll \cdot{ }^{18}$ Her viser det sig at investeringerne stiger $231 \%$ fra 1958 til 1969, mens »bankgælden«, der i vid udstrækning udgør kortfristede kreditter, ${ }^{19}$ altså er driftskreditter, stiger $285 \%$ i samme tidsrum. Den langfristede gæld stiger her $606 \%$, mens »anden gæld «, der først og fremmest omfatter leverandørkreditter ${ }^{20}$ stiger med $152 \%$ og aktiekapitalen endelig stiger med $148 \%$ i samme tidsrum.

Det gælder desuden her, at bankgælden udgør en langt større del af aktiekapitalen i 1969 end i 1958:

\begin{tabular}{|c|c|c|c|}
\hline & 1958 & og & 1969 \\
\hline Bankgælden i $\%$ af aktiekapitalen i: & $41 \%$ & & $65 \%$ \\
\hline Langfristet gæld i \% af aktiekapitalen: & $32 \%$ & & $91 \%$ \\
\hline Anden gæld i \% af aktiekapitalen: & $337 \%$ & & $342 \%$ \\
\hline
\end{tabular}

18. Kreditmarkedet og industriens ekspansion, af Carl Erik Sørensen, udgivet af Den danske Landmandsbank, 1971, s. 245.

19. ibd. s. 43.

20. ibd. s. 38 . 
Selv om stigningen $\mathrm{i}$ »anden gæld « delvis skyldes stigningen i skibsværfternes gæld og udenlandske firmaers lån hos moderselskabet, så viser dette skema, at kreditterne spiller en større rolle i det $\varnothing$ konomiske liv, og at stigninger i bankkreditten har været større end stigningen i den kommercielle kredit i forhold til aktiekapitalen.

Lad os nu give en bestemmelse af de formspecificeringer kapitalen underkastes gennem kreditten:

\section{2.a. Pengekapitalen:}

Pengekapitalen er bestemt af cirkulationens indhold: formidlingen af pengekredsløbet:

P - V $<$ produktionsmidler $\quad . .$. Produktionsproces... V' - P'.

Pengekapitalen (PK) er bestemt af den praktiske formidling af alle de transaktioner, hvori penge er involveret. PK realiserer en profit, der p.gr. af dens uproduktive karakter udgør et aftræk af merværdien. Dens forhold til gennemsnitsprofitraten er det samme som HK's og det er dens forhold til totalreproduktionen også: den kan formindske omslaget og følgelig gøre en forøget værdiproduktion mulig, ja måske under visse betingelser være med til at sænke produktionspriserne. Gennemsnitsprofitraten er dog generelt omvendt proportional med PK's størrelse. ${ }^{21}$

Bankvæsenet skal afledes af PK's formbestemmelser, men bankkapitalens egentlige rolle og virkning i totalreproduktionen er nøjere bestemt af rentekapitalen. Bankvæsenet spiller nemlig en stor rolle for kreditudvidelsen og her fremskyder bankerne ikke cirkulationsmidler, men derimod rentekapital. dvs. at en forøgelse af likviditeten sker i form af fremskudt rentekapital. Det samme sker, når nationalbanken gennem obligationsk $ø b$ forøger likviditeten: forretningen af obligationerne indebærer, at pengene er fremskudt som kapital. ${ }^{22}$

\section{2.b. Rentekapitalen:}

Rentekapitalen (RK) afledes af det samme kredsløb som PK og renten bestemmes som »kapitalens brugsværdi «, der jo består i at afkaste merværdi. ${ }^{23}$ Også i RK's form bliver kapitalen vare i egenskab af kapital, dens fetichering fuldendes. ${ }^{24}$ Renten bliver p.gr. af RK's uproduktive karakter en del af merværdien. RK forudsætter eksistensen af to typer kapitalister: kapitalejere og kapitalanvendere og på mange punkter er deres interesser i modsætning til hinanden.

21. Das Kapital bd. III, s. $451 \mathrm{ff}$.

22. Disse problemer berøres s. 546ff i bd. III af das Kapital.

23. Das Kapital, bd. III, s. 350ff.

24. Das Kapital, bd. III, s. $354 \mathrm{ff}$ og Theorien über den Mehrwert, bd. III, s. 445 ff. 
I afsnittet om revenukilderne i bd. III af Theorien über den Mehrwert og visse steder i bd. III af Das Kapital gør Marx en del ud af at fremhæve det forhold, at rentekapitalen bliver prototypen på kapital, således at kapitalanvenderen også betragter sin egen personligt investerede kapital i RK's form, således at han betragter sin profit som rente. Således vokser kapitalens værdiside afgørende sammen med den stoflige side, og får »værdi«, en ting, til at synes »produktiv«, tingsavlende. Med udviklingen af aktieselskabsformen og integration af kreditmarkedet er dette selvfølgelig rigtigt om kapitalens måde at »socialiseres « på, men det er forkert - som Marx gør - udelukkende at ville aflede kapitalismens mekaniske legitimationsbevis af RK's forhold til renten, sådan som det sker i den trinitariske formel, for den anvendte kapital har sine særlige illusioner der - som vi skal se - formes gennem konkurrencen: her synes profitten nemlig et produkt af kapitalsparsommelighed og ikke direkte et produkt af proportionelle kapitalstørrelser. Men de to illusionsformer udelukker selvfølgelig ikke hinanden.

Givetvis skal man dog i den trinitariske formel indarbejde modsætningen mellem IK og RK, der gør, at den enes profit er omvendt proportional med den andens, hvilket også på totalplan gælder forholdet til de respektive kapitalstørrelser.

Rentefoden er bestemt af følgende faktorer:

Rentefodens maximalgrænse er gennemsnitsprofitten - profit til den kapitalist, der anvender RK, eller løn til den person, der er ansvarlig for kapitalens produktive funktioner i det tilfælde, hvor den fungerende kapitalist kun har status af ansat. Rentefodens minimalgrænse er ubestemmelig, men at den ikke bliver så lav som man kunne tro har vist sig, når en statslig likviditetsforøgelse samtidig med faldende rente alligevel ikke har fået renten til at falde yderligere, fordi folk - med forventning om stigende rente - ikke har villet låne deres penge ud.

Ophævelsen af obligationsrationeringen i 1968 og kraftig likviditetsudpumpning fra nationalbankens side gennem obligationskøb i 1968 og begyndelsen af 1969, således at likviditeten forøgedes langt stærkere end nationalindkomsten, førte alligevel ikke til fald i renten. ${ }^{25}$

Ifølge Marx er der heller ikke nogen direkte sammenhæng mellem pengemassen og rentefoden. ${ }^{26}$ Dog skal man her være forsigtig med at blande pengemasseforøgelsen (likviditetsforøgelse) sammen med kreditforøgelse, fordi kreditten skaber andre former for udbudefterspørgselsstigninger end likviditetsforøgelse, der altid må forudsætte en akkumulation for at få nogen virkning.

På totalsamfundsmæssigt plan afgrænse gennemsnitsprofitraten altså rentefoden, mens rentefoden i sine nøjere bevægelser ikke behøver følge gennemsnitsprofitratens udsving, men her til dels er afhængig af en simpel udbud-efterspørgselsmekanisme på baggrund af de alternative muligheder for pengeanbringelse. Et stort obligationsmarked vil derfor kunne tvinge renten i vejret, det samme gælder et stort privat forbrug financeret gennem kreditgivning.

25. Kreditmarkedet og industriens ekspansion, ibd. s. 184.

26. Das Kapital, bd. III, s. 546ff. 
Der er altså mange medspillende faktorer ved bestemmelsen af det analytiske grundlag for renteniveauet, bl.a. spiller politiske forhold ind heri: den ringe diskontonedsættelse til 9\% per 14-1-75 var bl.a. udtryk for nationalbankens interesse $\mathrm{i}$ at forhindre, at en lavere rente herhjemme end i udlandet ville få folk til at indfri deres lån dér og tage dem op herhjemme i stedet, hvilket ville dræne valutakassen og igen sætte renten op. Derfor kun en ubetydelig diskontonedsættelse.

Fastsættelse af rentemarginalen er en anden vej at regulere renteniveauet på. ${ }^{27}$ Hertil kommer udlånsaftalerne mellem de private banker og nationalbanken og udlånsloftet, samt valutabestemmelserne. Marx påpeger, hvordan renteniveauet følger cyklens bevægelser således, at renten topper i krisens brændpunkt, hvor behovet for likviditet bliver katastrofalt: men generelt gælder det i alt fald, at rentefoden ikke som markedsværdierne ved en given udbud-efterspørgsels-tilstand har et »naturligt « niveau. ${ }^{28}$

Hvor rentefoden altså kun følger gennemsnitsprofitraten således, at et højt renteniveau over længere tid må have sin basis i et højt gennemsnitsprofitniveau, ${ }^{29}$ så afspejler rentefodens bevægelser derimod temmeligt nøjagtigt styrkeforholdet mellem to typer kapitalister: industri- og rentekapitalister. Derfor er der ingen selvfølgelig sammenhæng mellem en høj gennemsnitsprofitrate og store profitter til kapitalanvenderen, (Unternehmergewinn).

IK's profit er nemlig omvendt proportional med rentefodens højde. Derimod - siger Marx - griber RK ikke ind ved dannelsen af gennemsnitsprofitratens niveau, fordi der jo kun er tale om én kapital (værdistørrelse), der blot gennem transaktionerne mellem långiver (RK) og låntager (IK) skifter form.

RK indgår altså ikke som HK og PK (i bankers egenkapital) direkte i bestemmelsen af gennemsnitsprofitratens niveau, men klart nok indirekte, al den stund en meget lav profit til den fungerende kapitalist (Unternehmergewinn), vil mindske akkumulationen og dermed (under givne betingelser) værdiproduktionen i samfundet og således naturligvis gennemsnitsprofitraten, der jo på totalplan er forholdet mellem totalmerværdi og totalomkostningspris.

Den strengt systematiske forudsætning for at B kan låne kapital af A er, at B anvender denne kapital produktivt, at den anbringes således at den vil kunne afkaste merværdi. ${ }^{30}$ Anvender han den uproduktivt, altså til privat konsumtion, spekulation, etc., så vil den have samme virkning på gennemsnitsprofitraten som de negative virkninger af HK, idet den da udgør en merværdimasse, der har status af »materialiseret « krav på profit proportionalt med sin størrelse, men som ikke selv skaber værdi.

27. Lov om pengeinstitutters rentemarginal af 11-3-1975.

28. Das Kapital, bd. III, s. 372 ff.

29. Das Kapital, bd. III, s. 528.

30. Das Kapital, bd. III, s. 362. 
Således kan staten også - ved at opsuge dele af kreditmassen (nationalbanken sælger obligationer, sænker låneloftet eller strammer valutabestemmelserne; et eksempel på en kreditstramning er »Deponeringsaftalen « fra 1965 mellem nationalbanken og de private banker) - anvende den til produktive investeringer, f.eks. ved at låne den ud til investeringer i eksportindustrien på favorable vilkår, etc. Staten medvirker da til at bevare gennemsnitsprofitratens niveau. ${ }^{31}$ Anvender staten derimod kreditmassen som revenu, altså til efterspørgsel på SIII-varer, så vil virkningerne her være afhængige af hvorfra kreditmassen kommer. Kommer kreditten fra revenu beregnet på fremtidig konsumtion, så vil statens anvendelse af denne masse fungere som en overførsel af efterspørgslen fra nogle brancher eller sektorer til andre, og den vil da kunne stabilisere eller forhøje gennemsnitsprofitraten alt efter hvordan efterspørgslen virker på markedsværdiniveauet i de pågældende brancher.

Stammer kreditmassen derimod fra akkumulationsfonden, så vil statens konsumtive anvendelse af den begrænse den reproduktive produktmasse og skrue markedsværdiniveauet endnu højere op alt afhængig af akkumulationstempoet i SI og SII.

Men statens ekspropriering er ofte - f.eks. hvis det sker gennem udstedelse af statsobligationer - ikke nogen gratis ekspropriering, men kræver renteudgifter. Sådan »fiktiv kapital«, der blot har status af helt formelle krav på en andel af gennemsnitsprofitraten, men ikke har nogen forbindelse til de egentlige kapitalbevægelser (produktiv kapitalform) ${ }^{32}$, vil ligesom HK i dens negative virkning formindske gennemsnitsprofitraten ved at udgøre et krav på merværdi proportionalt med sin størrelse. Det ændrer intet ved den konklusion, at betalingen af renter af statsobligationer stammer fra fonds hentet via skatterne, fordi der her er tale om en faktisk formindskelse af merværdien. Af det foregående skulle det være tydeligt, at kredit aldrig med nødvendighed kan føre til dannelsen af IK, men er afhængig af gennemsnitsprofitrateniveauet og dermed af de stoflige betingelser for reproduktion i udvidet form på et givet tidspunkt indenfor brancherne. Der er ingen lineær kausalitet mellem forøgelse af kreditloftet og af omløbsmidlerne og så $\varnothing$ konomisk vækst, fordi penge blot er en form, hvori kapitalen eksisterer. ${ }^{33}$ På den anden side er der idag en helt tydelig sammenhæng mellem et højt kreditloft og en udvidet likviditet og så den stigende efterspørgsel, der gennem stabiliseringen og forhøjelsen af markedsværdiniveauet fører til inflation.

Dette forhold har den borgerlige stats politikere og embedsmænd i vidt omfang indset, og heri ligger keynesianismens grænser indenfor det borgerlige samfund selv.

31. Om måder at skaffe yderligere kreditmasse på gennem en'rationalisering af kredsløbet, se: Das Kapital, bd. II s. $346 \mathrm{ff}$.

32. Das Kapital, bd. III, s. 482 ff.

33. Das Kapital, bd. III, s. 442. 


\subsection{Reproduktionsskemaerne, kreditten og gennemsnitsprofitraten}

For en dybere forståelse af gennemsnitsprofitratens dannelsesbetingelser gennem statens indvirken på økonomien er det endelig nødvendigt at tage Marx' reproduktionsskemaer op til en behandling m.h. på en bestemmelse af efterspørgslens rammer. Efterspørgslen er her begrænset af to faktorer: kreditten og akkumulationsraterne i de forskellige sektorer.

I det følgende skal jeg med udgangspunkt i Marx' fremstilling af betingelserne for »akkumulation og udvidet reproduktion« $\mathrm{i}$ kapitel 21 af bd. II af Das Kapital illustrere virkningerne af en tredie sektor i økonomien.

Denne sektor kan godt være byggeriet - som det er tilfældet i forrige del - men her bliver den produktion da delvis af produktiv karakter, fordi dele af den indgår i arbejdskraftens reproduktion (almennyttigt boligbyggeri, hospitaler, skoler) og $i$ etableringen af transportbetingelser: broer, veje. (Hvis staten selv havde bygget disse ting, så ville de have været produktive i betydningen »reproduktive«, men næppe i betydningen »merværdiskabende «).

Tager vi derimod en produktion som krigsproduktionen, så er der her ikke tale om en produktion med merværdiskabende eller reproducerende funktion.

I det følgende skal konklusionerne generelt drages m.h. på begge mulige indhold af SIII, altså at SIII både kan rumme en produktiv og en ikkeproduktiv produktion.

Marx understreger i afsnit I af bd. II af Das Kapital, at det kredsløb hvorudfra reproduktionen skal anskues hverken er pengekapitalens eller den produktive kapitals kredsløb, men derimod varekapitalens, fordi denne (varekapitalen) både leverer produkter til den produktive og den private konsumtion: Kredsløbet ser således ud: ${ }^{34}$

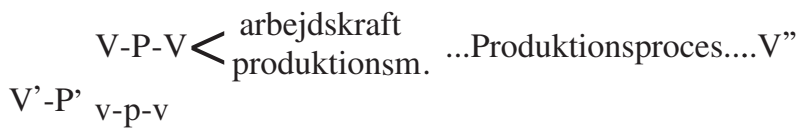

Det fors $\varnothing l v e d e$ vareprodukt kan altså anvendes i det »store« (reproduktive) eller »lille« konsumtive) kredsløb.

Heraf følger, at akkumulationsfonden alene kan tages af merværdien i SI og SII, da disse sektorer alene skaber et produkt, der har reproduktiv form (form af $k$ eller $v$ ), således må SIII tage hele sin kapital (både til simpel og udvidet reproduktion (akkumulation) af SI' og SII's merprodukt. ${ }^{35}$

Udvidet reproduktion i forbindelse med en tre-sektor-model ser således ud, hvis det forudsættes at hele merværdien akkumuleres (at der altså ikke er no-

34. Das Kapital, bd. II, s. 99.

35. Cogoy formulerer dette s. 155 i artiklen Werttheorie und Staatsausgaben i antologien Probleme einer materialistischen Staatstheorie, sammen med bidrag af Braunmühl, Funken og Hirsch. Suhrkamp 1973. Findes oversat i serien Politiske Arbejdstekster. 
gen privat konsumtion) og at merværdiraten (m') er ens i de tre sektorer: i SIII er den $159,3 \%$, i SI og SII: $160 \%$.

Forholdet mellem k/v er i SI ved akkumulation: 1/1, i SII: 1/1, og i SIII: 10/19. Tallene her er ganske vilkårlige, men reflekterer nok med rimelighed den empiriske sammensætning i de tre sektorer, hvis SIII dækker byggeriet.

\section{vareprodukt:}

1) SI: $4000 \mathrm{k}+1000 \mathrm{v}+1600 \mathrm{~m}$

SII: $1430 \mathrm{k}+351 \mathrm{v}+562 \mathrm{~m}$

SIII: $500 \mathrm{k}+182 \mathrm{v}+290 \mathrm{~m}$

2) SI: $4000 \mathrm{k}+1000 \mathrm{v}+500 \mathrm{~m}_{\mathrm{k}}+500 \mathrm{~m}_{\mathrm{v}}+600 \mathrm{~m}_{3}$

SII: $1430 \mathrm{k}+351 \mathrm{v}+70 \mathrm{~m}_{\mathrm{k}}+70 \mathrm{~m}_{\mathrm{v}}+372 \mathrm{~m}_{3}$

SIII: $500 \mathrm{k}+183 \mathrm{v}+100 \mathrm{~m}_{\mathrm{k}}+190 \mathrm{~m}_{\mathrm{v}}$

Betegnelsen »m« efter et tal med bogstavet $\mathrm{k}$, v eller tallet 3 under betyder, at det er en del af merværdien, der går til henholdsvis akkumulation af kvarer, vvarer og anvendes til akkumulation i SIII.

Akkumulationen sætter sig nu igennem som følger, først gennem udvekslingen mellem SI og SII:

3) SI: $4000 \mathrm{k}+500 \mathrm{mk}$ erstattes indenfor sektor I selv. Tilbage er $1000 \mathrm{v}+$ $500 \mathrm{~m}_{\mathrm{v}}+600 \mathrm{~m}_{3}$.

SII: $351 \mathrm{v}+70 \mathrm{mv}$ erstattes indenfor SII selv. Tilbage er: $1430 \mathrm{k}+70 \mathrm{~m}_{\mathrm{k}}+$ $372 \mathrm{~m}_{3}$.

4) Mellem SI og SII udveksles nu: $1000 v+500 m_{v}$ i form af $k$-varer byttes med $1430 \mathrm{k}+70 \mathrm{~m}_{\mathrm{k}}$ i form af v-varer.

Tilbage er da:

SI: $600 \mathrm{~m}_{3}$

SII: $372 \mathrm{~m}_{3}$

Denne del af SI' og SII's merværdi er beregnet til reproduktion og akkumulation i SIII:

5) SIII: $500 \mathrm{k}+100 \mathrm{~m}_{\mathrm{k}}=600 \mathrm{k}$ udbyttes med $600 \mathrm{~m}_{\mathrm{k}}$ fra SI.

$: 182 \mathrm{v}+190 \mathrm{~m}_{\mathrm{K}}$ udbyttes med $372 \mathrm{~m}_{3}$ fra SII.

SI og SII står da med en række varer fra SIII, som de pr. definition ikke kan anvende; de kan da sælge dem til staten eller billedet kan gengives således - som hos Cogoy - at SIII's reproduktive og akkumulative behov dækkes af staten gennem en ekspropriering af SI' og SII's merprodukt via beskatningen. Den sidste løsning er dog alt for simpel, fordi den overser det monetære perspektiv og dermed hele kreditformen.

Hvilke betingelser kan vi nu på baggrund af dette skema, der jo skildrer en $\varnothing$ konomi i perfekt ligevægt, slutte må gælde for reproduktionen under 
kapitalismen ${ }^{36}$ Thi tilfældet af ligevægt, hvor der altså hverken hersker overeller underproduktion i nogen af sektorerne er naturligvis helt enestående - et forhold der i kapitalismen sætter sig planløst igennem via gennemsnitsprofitratedannelsen og derfor snarere er et orienteringspunkt for produktivitetsdynamikken, der sætter sig igennem via cyklernes gennemsnit, men som aldrig behøver at afspejle en statisk tilstand for systemet.

Betingelserne for ligevægt er de samme her som vi påpegede for identiteten værdi-pris: det er en form for nødvendighed, der aldrig kommer til udtryk i en direkte statisk tilstand, men kun indirekte i grænserne for vækst; det er næsten som med tyngdeloven og linedanseren: hans balanceevne viser sig $\mathrm{i}$ at han ikke falder ned.

Udbuddet i en branche (en sektor består af en klynge af brancher) er bestemt af følgende faktorer: Ved konstant efterspørgsel er udbuddet afhængigt af: markedsværdiniveauet, virksomhedsantallet på de forskellige produktivitetsniveauer, produktivitetsforskellene og dermed forskellene i ekstramerværdi og ekstraprofit, de stoflige muligheder for produktivitetsudvidelse, altså af priserne på fast og cirkulerende kapital.

Afgørende for efterspørgslen ved konstant udbud er udbuddets markedsværdi og mulighederne for akkumulation og privat konsumtion (anvendelsen af merværdi eller dele af den som revenu). Hvis der f.eks., i SI er tale om et markedsværdiniveau, der svarer til det i SII, og der så udvikles de stoflige betingelser for akkumulation m.h. på produktivitetsudvidelse på baggrund af disse høje markedsværdier, så vil akkumulationstakten stige i SI, men således, at produktmassen ikke samtidigt forøges, thi ellers ville markedsværdiniveauet falde, hvilket ingen i sektoren er interesserede i. (Det fremkaldes derimod af konstant udbud, men faldende efterspørgsel).

Hvis akkumulationen har form af en udvidelse af den teknisk/ organiske sammensætning, så vil der indenfor SI blive større behov for k-varer (egne varer) end der skabes, dvs. at de k-varer, der muliggør en udvidet reproduktion i SII må indskrænkes. ${ }^{37}$ Således vil det omvendt være muligt at forøge den teknisk/organiske sammensætning indenfor SI (akkumulation) ved at forøge produktmasse uden at markedsvaerdierne falder, fordi SII's reproduktion og akkumulation - fremtvunget af gennemsnitsprofitraten der gør en udligning mellem ekstraprofitterne i SI og SII nødvendig - kræver en given masse SI-varer og fordi den stigende efterspørgsel på egne varer indenfor SI forøger efterspørgslen.

36. Både Mandel og Hickel har klart fremhævet det forhold at reproduktionsskemaerne i egenskab af ligevægtsmodel ikke kan anvendes til direkte konklusioner om kapitalismens faktiske forløb. E. Mandel: Das Spätkapitalismus, Suhrkamp 1973, kapitel 1. Hickel: Zur Interpretation der marxschen Reproduktionsschemata, trykt i Mehrwert nr. 2. Se også: J. F. Becker: Samhällelig obalans och Marx' system, trykt i Marx och den moderna nationalekonomi, red. af D. Horowitz, Stockholm 1970.

37. Das Kapital, bd. II. s. 491-496. 
Sker der samtidig en akkumulation indenfor både SI og SII, så vil markedsværdiniveauet i SI afhænge af den teknisk/organiske sammensætning i SI og SII og af den form hvorunder akkumulationen konkret foregår. Sker den gennem udvidelse af V(arbejderantal) så vil efterspørgslen ramme SII og have indflydelse på markedsværdiniveauet her: det vil stige og dermed bremse akkumulationen af $\mathrm{v}$ og muligvis tvinge den over i en akkumulation af k-varer. (Og vice versa).

Sagen er, at en underproduktion i SI eller SII kommer til udtryk gennem stigende markedsværdier og dermed gennem et lavere minimumsniveau for kapitalanlæg. Følgelig vil der strømme kapital til denne sektor og udbuddet vil stige på baggrund af loven om dannelsen af gennemsnitsprofitraten. Men en overproduktion vil komme til udtryk i faldende markedsværdier, hvilket igen vil kunne vende billedet, fordi produktionen indskrænkes eller fordi en ny akkumulation af fix kapital for altid forrykker markedsværdiniveauet nedad.

Statens rolle er meget væsentlig her, fordi den gennem investeringsstøtte og kreditoverførsler kan gøre akkumulationen i SII f.eks. mulig næsten i takt med en kraftig akkumulation i SI, således at der ikke gennem en underproduktin i SII sættes grænser for udviklingen af produktiviteten og dermed i særlig grad for konkurrencen med udlandet.

Staten står i en dobbeltrolle her, fordi støtten til udbuddet også er en støtte til efterspørgslen, og fordi hele reproduktionsskemaproblematikken - når den skal anvendes til konkrete analyser - må udvides m.h. på verdensmarkedet: større efterspørgsel efter SII-varer betyder konkret: større import af forbrugsgoder. Her kan staten ikke gribe særlig effektiv ind, fordi den ikke kan styre et forbrug der rent faktisk er muliggjort, dvs. at den - som vi skal se - er tvunget til at gribe generelt ind overfor hele efterspørgselsprismet, og dermed under samme hat både produktiv og privat konsumtion.

For udbuddets og efterspørgslens nærmere karakter er mange faktorer afg $\varnothing$ rende hvad angår de mindre betydelige bevægelser: Stigende eller faldende råvarepriser, ændringer i forbrugermønstre, afbetalingsordninger i forbindelse med kreditlofter, sæsonbestemt efterspørgsel, men de afgørende faktorer er og bliver udviklingen i fix kapital og udviklingen i arbejderklassens styrkeforhold.

Mandel skelner ${ }^{38}$ mellem tre typer maskiner hvis udvikling radikalt har ændret kapitalismens teknologiske basis: bevægelse-, transmissions- og arbejdsmaskiner. Især udviklingen i bevægelsesmaskinerne: fra damp- via diesel- til elektro- og elektronik og disse energimaskiners maskinelle fremstilling har ifølge Mandel karakteriseret kapitalismens konjunkturbevægelser i store træk.

Arbejderklassens styrkeforhold er en meget kompleks størrelse, der ikke kan afgrænses rent » $\varnothing$ konomisk «, men også kræver et organisationspolitisk perspektiv.

38. Mandel, ibd. s. 109-113. 
Af alt dette følger, at den simple og udvidede reproduktion under kapitalismen er bestemt af værdiproduktionen: det kommer til udtryk i loven for gennemsnitsprofitratens dannelse og det udtrykker, at producenten er gjort magtesløs overfor sin egen produktion: indførelsen af ny teknik er helt afhængig af profitniveauet, og arbejderklassens rolle i produktionsprocessen er ligefuldt underkastet valoriseringens lov.

Værdien som »processerende værdi« - som Marx så ofte siger i Grundrisse - er kapitalismens væsen, men dette væsen eksisterer kun i sin fremtrædelse, og den er loven for dannelsen af gennemsnitsprofitraten, altså konkurrencens begreb. Skal reproduktionsskemaerne, ja hele analysen på niveauet-for-kapital-i-almenhed have forklaringsevne overfor senkapitalismens fænomener, skal denne fremstillings resultat: indsigten i kapitalrelationen, drages ind gennem konkurrencen. En streng »niveaupietisme « som vi f.eks. ser den hos Yaffe $^{39}$ gavner ikke klassekampens sag, for kun integration af niveauerne - på baggrund af indsigten i deres forskellige forklaringskraft naturligvis - kan give arbejderklassen det analytiske værktøj i hænde, der gør en rigtig strategi mulig.

Det er f.eks. klart af sammentænkningen af reproduktionsskemaerne med ${ }^{40}$ konkurrencens begreb, at man kan se, at en akkumulation i SI der ikke er fulgt op af en akkumulation i SII kan bremses i sit akkumulationstempo af SII's slendrende fart, hvilket kan føre til en intensivering af arbejdet i SI og til en forværring af konkurrencebetingelserne på verdensmarkedet, hvilket igen virker tilbage på arbejderklassens vilkår: fordi det manglende fald i markedsværdierne, der skulle være indtruffet analogt med akkumulationen og altså produktivitetsudvidelsen i SI, fører til forskellige forsøg på at begrænse omkostningspriserne ad anden vej, og denne vej er som regel fastfrysning af lønninger, arbejdsintensiveringer, etc.

På dennne baggrund er det også helt tydeligt, at en opstilling af en model for den kapitalistiske totalreproduktion, der ikke indeholder en monetær synsvinkel, vil være relativ værdiløs hvis den skal anvendes til at belyse udviklingen i kapitalismen med, eller vise statsinterventionismens grænser. ${ }^{41}$

Marx understreger nemlig, at stofskiftet mellem SI og SII kræver, at der fremskydes en vis sum penge til at realisere vareproduktet og danne udgangspunkt for transaktionen. Men denne pengemasse kan ifølge Marx kun være tidligere forsølvet merværdi, altså enten være akkumulationsfondens eller revenuens pengeform eller være fremskudt gennem handel med guld-

39. D. S. Yaffe: Værdi og pris i Marx' kapital, trykt i Kritik af den neoricardianske marxisme, Modtryk 1975.

40. Das Kapital, bd. II, s. 505 ff og s. 508.

41. Cogoy, ibd. 
varesektoren. ${ }^{42} \mathrm{Nu}$ er det blot tydeligt, at skulle staten tage penge fra SI, SII og SIII med henblik på at anvende disse til at købe SIII's vareprodukt, så ville det indebære et højere akkumulationstempo i SI og SII (og/ eller en gevaldig intensivering af arbejdet) for at merværdien også skulle kunne dække hele SIII's produktværdi $(\mathrm{k}+\mathrm{v}+\mathrm{den}$ i SIII skabte merværdi, der ifølge vores skema akkumuleredes rub og stub).

Det er betingelsen for ligevægtig reproduktion og akkumulation i forholdet mellem de to sektorer (SI og SII), at der ikke opstår nogen overskydende kapital i form af varer eller penge, thi det er identisk med overproduktion i en af sektorerne eller underproduktion i en anden.

Skal SII f.eks. betale $n$ varer i skat, så er det udtryk for at en given varemasse ikke kan anvendes til $k \varnothing b$ af varer i SI - dvs. at akkumulationen bremses i SI eller ikke udvides i et givet - måske af konkurrencen på verdensmarkedet kræver - tempo. Tænkes skatten monetært - og det er jo netop skattens særlige historiske rolle under kapitalismen at blive opkrævet i pengeform og dermed være en af de faktorer, der fremtvinger den kapitalistiske udvikling ved at omdanne naturalieøkonomi til pengeøkonomi - så er det indlysende, at opkrævning af skat i pengeform ikke blot kræver en ophobning af en given varemasse, der tidligere anvendtes til akkumulation, men også, at denne varemasse må have været forsølvet for at kunne fungere som skat, at den altså må foreligge i pengeform.

Hvis forvandlingen fra vareform til pengeform da tænkes foregået mellem SI og SII, så kan den kun betyde bremsning af akkumulationen ved at betyde et manglende genk $\varnothing \mathrm{b}$ i en af sektorerne eller et stop i en given fælles akkumulationsrate. Skal den være opnået gennem en vareudveksling med SIII, så betyder det naturligvis, at bremsningen også kan ramme SIII, at akkumulationen altså også stopper dér, eller endog reproduktionen alt efter skattens størrelse.

Rammer skatten lige hårdt $\mathrm{i}$ alle sektorer - hvilket empirisk set er et delikat spørgsmål, da skattesystemet m.h. på beskatning af kapital er meget indviklet og skattens størrelse afhængig af den enkelte kapitalists evne til at udnytte skattelovens fordele, men forudsætter vi at alle kapitalgrupper er lige gode til det og har lige stoflige muligheder for det, så kan vi antage en ensartet skatteprocent på kapitalerne i alle sektorer - så kræver det en stærkere akkumulation i SI og SII end det ellers ville være påkrævet, alt afhængigt igen af skattens størrelse, akkumulationsraten i SI og SII, og SIII's størrelse og akkumulationsrate og akkumulationssammensætning.

Men tænkes stofskiftet mellem SI, SII og SIII på baggrund af en monetær skattemodel, så er det indlysende, at problemet overhovedet ikke kan løses uden kredittens begreb. For Cogoys løsning, der går ud på at SIII's kapitals produktive form er eksproprieret af staten, bryder med hele statens legitimationsbasis og eksistensbetingelser: for staten kan ikke overskride cirkulationssfærens formelle

42. Das Kapital bd. II, kap. 17. Fremstillingen er her ufuldendt og har karakter af skitse til en systematisk angrebsvinkel på de omtalte problemer. 
reglement: at man erhverver gennem bytte. Staten er således bittert afhængig af forvandlingen af vareproduktet til pengeform, så meget mere som staten overhovedet ikke ville kunne anvende en skattemasse i form af naturalier.

Staten kan altså ikke tage varer fra SI og SII og give til SIII som basis for dennes produktive kapital, men staten må give SIII penge, således, at SIII kan $k \phi b e$ sine reproduktive varer hos SI og SII.

Skærer vi den historiske dimension ud et øjeblik, der ville gøre det hele unødigt vanskeligt, så gælder følgende: SIII's betalingsmidler i forholdet til SI og SII må indgå i totalstofskiftet mellem SI, SII og SIII uden at vare resultatet af forvandlingen af et vareprodukt til pengeform. SIII må altså enten have modtaget pengene i egenskab af RK (rentekapital), i egenskab af forudbetaling, eller forholdet mellem SIII på den ene side og SI og SII på den anden må tænkes ud fra den komercielle kredit. (To kapitalister fremskyder et vareprodukt til hinanden uden mellemkomst af penge).

Virkningen af dette forhold er entydigt det jeg beskrev i del I, og som jeg igen har understreget i denne del: at efterspørgslen på SI - og SII-varer overstiger udbuddet og at markedsværdiniveauet derfor kan stige eller holde sig stabilt trods akkumulation.

Marx' gentagne spørgsmål i kapitel 17 af bd II af Das Kapital: hvorfra kommer pengene til at fors $\varnothing l v e$ (forvandle fra vareform til pengeform) merproduktet? synes at have relevans her. Forestiller man sig at de kommer fra tidligere forsølvet merværdi, så ligger der heri en absurditet, idet der aldrig i samfundet kan realiseres større merværdimasse end produktværdien af det tidligere omslag muligg ør. En forsølving af en større meværdimasse kan altså kun ske, hvis omkostningsprisen bliver mindre fra omslag til omslag.

Systematisk kan dette problem heller ikke løses gennem inddragelsen af guldvaresektoren, for det indebærer, at guldvaresektorens merværdiproduktion skulle være identisk med totalmerværdien i det $\varnothing$ vrige samfund, en antagelse Marx selv afviser som absurd s. 487 i bd. II af Das Kapital.

Ejheller kan problemet løses gennem den antagelse, at visse kapitaler på et givet tidspunkt ikke akkumulerer, men henlægger deres akkumulationsmateriale $\mathrm{i}$ fonds, der så figurerer som kapitalens produktive form for andre akkumulerede kapitaler, thi dette forøger jo ikke totalpengemassen i forhold til totalmerværdimassen. ${ }^{43}$

Den eneste måde problemet om forvandingen af et større merprodukt i vareform til pengeform kan løses systematisk på er gennem inddragelsen af staten som henholdsvis fremskyder af cirkulationsmidler i form af penge og i form af kapital. Der er altså her tale om statens udstedelse af pengesedler og dens regulering af rentekapitalens omfang i de private banker, og af dens fastsættese af valutabestemmelser, altså først og fremmest af omfanget af kreditten opnåelig i udlandet.

43. Das Kapital, s. 337 og s. 345 ff. 


\title{
4.4. Konsumtionens rolle i totalreproduktionsprocessen
}

\author{
Når Marx s. 500-501 i bd. III af Das Kapital siger:
}

»Lad os forestille os, at hele samfundet kun bestod af industrielle kapitalister og lønarbejdere. Lad os videre se bort fra de prisbevægelser, der forhindrer store dele af totalkapitalen $\mathrm{i}$ at reproduceres ved gennemsnitsforhold, og som, på baggrund af hele reproduktionsprocessens almene sammenhæng, således som kreditten i særlig grad udvikler den, altid må frembringe midlertidige almene blokeringer. Lad os også se bort fra de skinforretninger og spekulative omsætninger, som kreditvæsenet befordrer. I så tilfælde ville en krise kun kunne forklares ud fra misforhold mellem produktionen i forskellige brancher og ud fra et misforhold mellem kapitalisternes egen akkumulation og konsumtion. Men som sagerne nu forholder sig, så er erstatningen af de til produktion anvendte kapitaler i vid udstrækning afhængig af de ikke produktive klassers konsumtion, mens arbejdernes konsumtionsevne derimod dels er begrænset gennem arbejdslønnens lovmæsigheder, dels gennem det forhold, at de (arbejderne) kun bliver anvendt sålænge de kan anvendes med profit af kapitalistklassen. Den yderste årsag til alle virkelige kriser forbliver derfor massernes fattigdom og konsumtionsbegrænsning i forhold til den kapitalistiske produktions drift mod en udvikling af produktivkræfterne, der kun finder sin grænse i samfundets absolutte komsumtionsformåen.« Og når han videre i en fodnote til sit manuskript til bd II af Das Kapital siger: ${ }^{44}{ }$ Modsigelse i den kapitalistiske produktionsmåde: Arbejderne i egenskab af købere er vigtige for markedet. Men som sælgere af deres vare - arbejdskraften - har det kapitalistiske samfund tendens til at begrænse den til minimumspis. - Yderligere modsigelse: De epoker, hvori den kapitalistiske produktion anstrenger alle sine potenser, viser sig regelmæssigt at være epoker med overproduktion, fordi produktionsmulighederne aldrig kan anvendes i et sådan omfang, at der derigennem ikke kun produceres mere værdi, men også realiseres mere; salget af varerne, realiseringen af varekapitalen, altså også af merværdien, er derimod begrænset, ikke gennem samfundets absolutte konsumtive behov, men gennem de konsumtive behov hos et samfund, hvori hovedparten til stadighed er fattige og må forblive fattige...«

- når Marx altså siger således - så er det langt snarere end at være et impulsivt underkonsumtionsteoretisk dogme den antagelse, at bevægelserne i efterspørgslen i det kapitalistiske samfund ikke bestemmes af udsving i arbejderklassens konsumtion indenfor en given lønramme, men derimod, bestemmes af forholdet mellem merværdi og arbejdsløn, eller af totalarbejdslønnen og totalmerværdien.

Heri ligger klart den indsigt som også Keynes formulerer, og som går ud på, at opsparingen i et samfund og behovet for likvide midler er størrelser, der med mindre de omsættes til industrikapital direkte blokerer for samfundes vækst.

Keynes skelnede ikke mellem IK og HK og havde ikke noget »produktivitetsbegreb « som vi kender det fra Marx, men hans General Theory, der er blevet tolket således, at de personer han skriver om skulle være kapitalister og arbejdere i flæng, angår først og fremmest enkeltkapitalisten og hans opsparing, der i form af spekulation og besiddelse af konti eller private gemmer spækfyldt med kontanter, er ødelæggende for den samfundsmæssige vækst.

Keynes kunne selvfølgelig p.gr. af sine politiske interesser, der også var hans erkendelsesteoretiske, ikke se det Marx her så ifølge de sidste to citater, men

44. Das Kapital, bd. II, s. 318, fodnote 32. Dette og det foregående citat er min overs. OFK. 
han kunne se, at kapitalistklassens jagt efter merværdi udhulede akkumulationen, al den stund besiddelse af store likvide midler ikke behøvede være udtryk for en stigning i kapitalens grænseydelseseffektivitet. Marx' lov for den kapitalistiske akkumulation, der udtrykkes i tesen om profitrates faldende tendens på det konkreteste niveau, indeholder den indsigt, at arbejdslønnen aftager relativt i forhold til fix og cirkulerende konstant kapital, også selvom den stiger absolut.

Marx' tese om den stigende kapitalistiske forarmelse, der ikke holder stik idag, har alligevel en kerne af sandhed: for »forarmelse« betyder: indskrænkelse af antallet af produktive arbejdere i løbet af den kapitalistiske akkumulation relativt til stigningen i maskiner og materiel. Men det betyder også indskrænkelse af mængden af produktive arbejdere i forhold til mængden af uproduktive arbejdere.

Dette forhold giver samme resultat som forarmelsestesen hvad angår gennemsnitsprofitraten: den vil falde, fordi kun de produktive arbejdere skaber merværdi.

Den efterspørgsel som de uproduktive arbejdere skaber realiserer nok merværdi, men den begrænser også merværdimassen på totalplan, fordi uproduktive arbejdere pr. definition er arbejdere, der ikke skaber merværdi, dvs. hvis løn tages af revenuen, og altså direkte medvirker til at sænke gennemsnitsprofitraten, hvad enten den indgår i en kapital som HK eller PK, eller blot indgår som løn til tjenester.

Statens efterspørgsel på uproduktivt arbejde har da allerede her karakter af en politisk motiveret begrænsning af forarmelsen, men dette er selvfølgelig ikke hele sandheden, selvom keynesianismen givetvis af sin fader og af sine faddere et tænkt forebyggende, klassemodsætningsdæmpende.

Lad mig ridse grænsen for den private konsumtion op, altså for merværdiens anvendelse til revenu, og dermed virkningerne af sådanne bevægelser på totalreproduktionen:

Hvis vi opdeler totalmerværdien i samfundet i tre poster:

$\mathrm{M}_{\mathrm{a}}$ : merværdi til akkumulation

$\mathrm{M}_{\mathrm{f}}$ : merværdi til privat forbrug

$\mathrm{M}_{\mathrm{o}}$ : merværdi til opsparing, der ikke er investeringer, så er det klart nok, at udvidelsen af opsparingen har begrænsende virkning på $\mathrm{M}_{\mathrm{a}} \circ \mathrm{og} \mathrm{M}_{\mathrm{f}}$.

Hvilke virkninger en forøgelse af $\mathrm{M}_{\mathrm{f}}$ vil få er derimod bestemt af hvilke varetyper den anbringes i:

Anbringes den i SIII-varer har den givetvis en negativ virkning på akkumulationen, fordi den vil få markedsværdierne på SI-og SII-varer til at stige, fordi efterspørgslen på disse varer vil overgå udbuddet.

Arbejderklassens indtægt er pr. definition ikke kapital for arbejderen, men kan i egenskab af revenu forvandles til kapital under en kapitalists »varetægt«. Men det kan selvfølgelig spille ind på totalreproduktionen, hvis arbejderen sparer op af en given lønmasse, idet det reducerer efterspørgslen på SII-varer. Hvilken effekt opsparingen vil have er aldeles afhængig af dens funktion som kredit gennem bankerne, dvs. hvilken type varer den qua RK omsættes i. 
Men som allerede nævnt er bevægelsen mellem forbrug og opsparing ikke af den store betydning for totalreproduktionen, når det er arbejderklassen der er tale om.

Det moment derimod, der virkelig medfører størrelsesforskydninger mellem $M_{a}$ og $M_{f}$ og $M_{o}$ er bevægelserne i gennemsnitsprofitraten og dernæst forholdet mellem den fungerende kapi talists profit (Unternehmergewinn) og så renten.

Denne indsigt behersker Keynes' hovedværk og går igen i hele den moderne borgerlige politik. Keynes' begreb for opsparing, der bl.a. indeholder forestilling om en tilbøjelighed for besiddelsen af likvide midler er dog temmelig absurd al den stund det er absurd at tænke sig at folk ville ligge inde med penge $\mathrm{i}$ en samfundsmæssig sammenhæng, hvor pengebesiddelse uden forrentning opfattes som direkte tab, og faktiske er det på baggrund af prisstigningerne. Dette betyder at opsparingen og »hoarding « praktisk er det samme, dvs. at opsparing og investering kun kan skilles fra hinanden hvis man tænker sig opsparing som investering i obligationer og spekulative emner, mens »investering « bliver udlån til industriformål. Den moderne politik viser, at denne type opsparing er en hård nød at knække for regeringen, fordi obligationsrenten er vanskelig at påvirke.

Indfører vi sektormodellen i forbindelse med $\mathrm{M}_{\mathrm{a}}, \mathrm{M}_{\mathrm{f}} \mathrm{og} \mathrm{M}_{\mathrm{o}}$, så er det klart at akkumulationsraten i de forskellige sektorer er afgørende for opsparingens rate, dvs. at spekulation og obligationshandel i vid udstrækning - men naturligvis ikke totalt - er omvendt proportionalt med akkumulationen.

En stigning i den private konsumtion vil kunne give overakkumulation i SI eller underakkumulation i SII, fordi markedsniveauet vil stabiliseres der; men her er vi inde i et problem, hvilket jeg ikke vil gå nøjere ind på her.

Lad os nu gå over til en nøjere udvikling af statsinterventionismens begrænsninger:

\subsection{Totalreproduktion og statsintervention}

På baggrund af Matticks overvejelser i bogen Marx og Keynes angående statsinterventionismens grænser har Cogoy opstillet en tese om hvilke grænser for statsinterventionisme, der følger af kapitalens produktive form:

Gennem indførelse af en tre-sektormodel i stil med den vi lige har fremført, men med udeladelsen af ethvert monetært perspektivt, mener Cogoy at kunne slutte, at »Totalkapitalens akkumulation er ikke mere identisk med summen af den af hver enkeltkapital frembragte merværdi. Totalkapitalens akkumulation er identisk med summen af totalmerværdien minus totalværdien af SIII's produktion. $\ll^{45}$

45. Cogoy, ibd. s. 155. Min overs. OFK. 
Denne konklusion er - som jeg har vist - fuldt berettiget, når SIII's vareproduktion ikke har reproduktiv form.

Men Cogoys videre konklusioner herfra er behæftet med nogle meget typiske fejl: ikke blot således om jeg har påpeget, at hans mangel på et monetært perspektiv og på hele kreditperspektivet gør hans konklusioner meget abstrakte, men således, at hans bestandige opereren på niveauetfor-kapital-i-almenhed gør hans konklusioner uanvendelige på kapitalismens konkrete udviklingsgang.

De ligger tæt op af Matticks opfattelse af forholdet, der lyder som følger:

»Fra et profitsynspunkt betyder overproduktionskrisen således en situation, hvor eksisterende kapital samtidig er for lille og for stor. Den er for stor i forhold til den eksisterende merværdi og den er ikke stor nok til at overvinde manglen på merværdi ${ }^{46}{ }^{46}$

Heri ligger spillet på kapitalens enhed af værdi og brugsværdi: værdimæssigt er merværdimassen, der udvindes af den eksisterende kapital, for lille til fortsat reproduktion, det betyder at gennemsnitsprofitraten falder. Samtidigt er det stoflige indhold af merværdien, altså merproduktets produktive form for lille til at gøre den akkumulation mulig, der kan forøge gennemsnitsprofitraten eller i alt fald skabe ekstraprofitter.

Hovedsvagheden ved Cogoys gennemførelse af dette - på lang sigt og på et abstrakt niveau sandsynligvis rigtige - argument er, at det ikke orienterer sig i forhold til gennemsnitsprofitratens dannelseslov. For tager man kreditten med ind, plus et begreb for vækstrateforskellighederne i de tre sektorer, så synes det ikke absolut nødvendigt, at SIII's eksistens skulle medvirke til en begrænsning af værdiproduktionen i samfundet eller til sænkning af akkumulationsraten, der indebærer yderligere hæmmet værdiproduktion.

Vores undersøgelser i del I af denne artikel viser derimod, at eksistensen af SIII kan betyde en stabilisering af værdiproduktionen ${ }^{47}$ gennem en stabilisering, ja forøgelse af markedsværdiniveauet, fordi efterspørgslen overgår udbuddet over længere tid.

Der er altså gennem konkurrencens begreb givet mulighed for at prisdannelsesmekanismen indeholder evnen til at kompensere for tabet på profit som følge af skatterne.

46. P. Mattick: Marx og Keynes, Blandingsøkonomiens grænser, Røde Hane, København 1973, s. 63.

47. Og af værdirealiseringen, hvis vi ser på den nationale økonomi som en integreret del af verdensmarkedet. Gennem lån i udlandet skaffes der dækning for den »falske sociale værdi« realiseret i sektor III. Et væsentligt perspektiv angående sammenhængen mellem værdiproduktion og værdirealisering er problemet om hvorvidt den stigende organiske sammensætning betyder en så stærk indskrækning af arbejderklassens beskægtigede del, at købekraften falder i samfundet, dvs. at det producerede ikke kan realiseres. Dette er i sin disproportionale konsekvens et vægtigt argument fra Marx’ side mod Ricardos ligevægts-naturalisme, men argumenterne - der udvikles i bd. II af Theorien über den Mehrwert, kap. 17 - er ikke gennemførte. Dette perspektiv er udeladt i denne sammenhæng, da det fordrer et noget andet perspektiv på problematikken. Se i $\emptyset$ vrigt tidsskriftet Mehrwert, nr. 5, kap. 7 og 8. 
Det er altså - som jeg har vist - strengt nødvendigt at focusere på konkurrencen indenfor og mellem brancherne for at kunne afgøre virkningerne af statsinterventionismen.

Heri ligger naturligvis ikke, at dette er et forhold der kan fortsætte over virkelig lang tid: ekstraprofitterne skabes i høj grad ved hjælp af »falsk social værdi«, der dækkes ind gennem import af lånekapital fra udlandet og ad andre veje, men som i længden kræver en udligning, der medfører katastrofale forhold for nationen på verdensmarkedet, hvis den ikke indtræffer.

Men samtidig indebærer det forhold, at den af Mattick og Cogoy fremhævede tendens i kapitalismen, at der i længden vil fremkomme en overproduktion af kapital og en underproduktion af nyværdi, ikke kan give anledning til direkte uformidlede konklusioner angående statsinterventionismens grænser. Thi den nævnte tendens - der jo først fremhævedes af Marx i hele sin konsekvens - er ikke bare bundet til en særlig form for kapitalisme, men hører til kapitalismen som produktionsmåde. Grænserne for statsinterventionisme består nemlig ikke primært i en begrænsning af profitten overalt i samfundet, men derimod i udviklingen af et heterogent og alt for højt prisniveau, samt $\mathrm{i}$ forværringen af landets internationale stilling gennem en beskæftigelsessituation, der er vanskelig at bære for de mindre firmaer i eksportbrancherne, fordi den presser lønningerne i vejret.

Statsinterventionismen bremser langt snarere på hjemmemarkedet akkumulationen og giver anledning til produktivitetsforøgelse gennem intensivering af arbejdet, fordi konkurrencen p.gr. af statens efterspørgselsstabilitet er betydelig reduceret, (produktivitetsforøgelsen sker da ikke gennem anskaffelsen af ny fix kapital). Statsinterventionismen bremser altså delvis profitratens faldende tendens. Mens den altså sikrer profitten på hjemmemarkedet vanskeligg $\emptyset \mathrm{r}$ den situationen for eksportindustrien ved at bremse sænkningen af produktionspriserne her, hvilket medfører at profitraten falder i disse brancher, fordi profitterne på verdensmarkedet er direkte proportionelle med produktivitetsniveau, jo højere produktivitet desto højere profitter.

Statsinterventionismen kan ikke redde kapitalismen, ingen har bedre bevist det end den borgerlige stat selv indenfor de sidste to år. Men inddragelsen af konkurrencens, kredittens og verdensmarkedets begreber viser os, at loven for den kapitalistiske akkumulation som den er formuleret på niveauet-for-kapital-i-almenhed ikke sætter sig uformidlet igennem i statsinterventionismens begrænsninger, men går via dannelse af gennemsnitsprofitraten og produktionspriserne, og her viser det sig at statsinterventionismens grænser ligger i dens delvise bremsning af akkumulationen, i dens skabelse af en modsætning mellem nation og verdensmarkedet gennem en passificering af konkurrencen $i$ hjemmeindustrien, og dermed frem for alt, i dens blokering af dannelsen af en gennemsnitsprofitrate i samfundet. 


\section{Kapitel 5:}

\section{Konsekvenserne af statsinterventionismen}

Statsinterventionismens årsager skal søges i forholdet mellem det kapitalistiske samfunds økonomiske basis og så dets politiske overbygning: De modsætninger, der konstituerer basis og som angår besiddelse og ikkebesiddelse af ejendom er det statens opgave at bevare i en konfliktløs form.

Men i selve de ejendomstrukturer, der afgrænser kapitalismen, ligger rammer for interaktion, der netop kommer tydeligst til udtryk i forholdet mellem kapitalist og arbejder. Engang sat bliver ejendomsforholdene i kapitalrelationen til et selvstændigt væsen med sit eget liv, sine egne love og sin egen indre logik. Denne logik indgår i vores samfunds- og tilværelseserfaring gennem vor daglige aktion indenfor kapitalrelationens rammer. Således avler kapitalen sine egne illusioner i sine mere eller mindre villige aktørers bevidsthed. Disse illusioner, der tydeligst er formuleret i »den trinitariske formel « af Marx, illuderer at kapitalismen er et retfærdigt samfund, et rationelt, funktionalistisk samfund, hvor mennesket og teknik og videnskab udvikles bedst, eller i alt fald bedre end andre steder. Staten bliver da en enhed med en økonomiske basis i revenukildebegrebet: revenukildernes eksistens, og revenuens sikring, omfang og kontinuitet smelter sammen med statens funktion. Den kapitalistiske stat er eksistensen af de tre revenukilder. Alligevel må staten på mange punkter bryde denne sin passive eksistens og manifestere en anderledes, særskilt side af sig selv, for den politiske form, hvori kapitalismen efterhånden overvintrer i den vestlige verden: parlamentarismen, er ikke ganske funktionalistisk indrettet m.h. på kapitalismens bevarelse. Naturligvis er parlamentarismen også vokset sammen med revenukildebegrebet, der danner dets erfaringsmæssige basis, men der ligger i parlamentarismen qua syntesen af revenukildeviljer ikke den konkrete form, hvorunder enheden eller modsætningen i disse viljer effektueres.

Hvor den fascistiske stat på punkter passer meget bedre til virkeligg ørelsen af kapitalismens behov i egenskab af produktionsform, så blokerer parlamentarismen ofte for virkeligg ørelsen af totalkapitalens behov.

Hvor det, at staten MÅ udspaltes i en række instanser, må blive en udfarende kraft, principielt følger af modsætningerne mellem revenukilderne, så følger formen hvorunder staten farer ud ikke af revenukildernes væsen.

Keynes' værk f.eks. tjener glimrende som illustration til det forhold, at revenukildeejerkonflikterne ikke måtte træde åbenlyst frem i samfundet: Keynes anbefalede hellere prisstigninger end løntrykning af politiske årsager - men kun hvis vi udvikler et differentieret begreb for revenukilderne kan vi udlede de mål og midler hvormed Keynes mente staten burde træde ind på arenaen. 
Denne differentiering består i fremdragelsen af kapitalformerne på niveauetfor-kapitalen-i-dens-realitet: industrikapital, handelskapital, pengekapital, rentekapital, altså i en fremdragelse af konkurrencens niveau og af totalreproduktionsperspektivet og af de kapitalfraktioner, der konstituerer totalkapitalbegrebet, og $\mathrm{i}$ en focusering af verdensmarkedets problematik. Nøglen til forståelsen af hvordan statens essens bliver til eksistens er altså at se hvilke former kapitalen på sit konkreteste niveau udspalter sig i, og derudfra - på baggrund af begrebet »materiel interesse «, der angiver den aktions - og erkendelseradius som findes hos individer bundet til deres ejendomsbesiddelse - lokalisere handlingshorisonten for de personer, der tager statens eksistens på sig.

Keynes f.eks. kan lokaliseres i modsætningen mellem industrikapitalister og rentekapitalister, hvor han uden at ændre samfundets struktur ville gribe ind til fordel for de første. Statens identitet som spændingsfeltet mellem en række særinteresser gør, at alle konkrete løsninger må forholde sig til totaliteten, dvs. Keynes kunne ikke bare afskaffe rentekapitalen, men måtte begrænse rentekapitalen under den forudsætning at hans løsning skulle kunne accepteres af alle også - omend blot på parlamentarismens formelle kriterier - af rentekapitalen selv. Skal vi indenfor de sidste år se hvilken grundforestilling, der bliver udslagsgivende for statens aktion, så er det vel nok nationen set i forhold til verdensmarkedet, dvs. ophøjelsen af industrikapitalen til »nationalkapital «. Men derom senere.

Problemet om statens muligheder som aktør overfor sin eksistensbasis men naturligvis kun indenfor rammerne af denne - er givet som problemet om forholdet mellem erkendelse, midler og muligheder: for det første grænserne for den indsigt den borgerlige politiker eller embedsmand har ifølge sine erkendelsesinteresser i deres spejling af den måde kapitalens objektive love fremtræder på i en given historisk konstellation, midlerne han har til rådighed på baggrund af systemets integritet og endelig hans handlingsmuligheder i forhold til sine politiske meningsfæller og modstandere. ${ }^{48}$

Her adskiller statsinterventionismen sig fra tidligere og seneste politik, ved at reproducere kapitalens illusioner på en ganske særlig måde i ord og gerning.

I det følgende skal statsinterventionismens konsekvenser og grænser opridses ud fra udarbejdelsen af den objektive indsigt i disse grænser i det foregående.

Dernæst skal det borgerlige samfunds egen opfattelse og reaktion mod statsinterventionismen på visse punkter udvikles. Men her tilsigtes ingen komplet fremstilling af statsinterventionismen og dens modtræk, bl.a. focuseres indkomstpolitikken kun i ringe grad, etc. derimod søger jeg mod det perspektiv, der belyser, hvordan staten i sine forskellige aktionsformer forestiller sig det kapitalistiske samfunds funktionsmåde, dvs. hvordan staten forholder sig

48. Erik Ib Schmidt: Dansk Økonomisk Politik, Fremad, 1974, Indledningen. 
til konkurrencens begreb og kapitalformerne. Altså: hvor går grænserne for rationaliteten i den borgerlige stats aktioner?

At tale om positive og negative konsekvenser af statsinterventionismen kan være rimeligt, men en sådan opdeling af konsekvenserne skal ikke foretages her, da de positive og negative momenter er integreret i hinanden. Indledningsvis skal det dog pointeres, at den positive hovedkonsekvens af statsinterventionismen er stabiliseringen af den kapitalistiske basis gennem en stabilisering af de politiske modsætninger henimod et stade, hvor deres eksistensformer lader samfundets evne til at fungere som en enhed bestå: udviklingen af et socialt sikkerhedsnet og underst $\varnothing t t e l s e n$ af gennemsnitsprofitraten er her de væsentligste resultater.

\subsection{Statsinterventionens bestemmelse}

\section{1.a. Markedsvardiniveauet}

På baggrund af 3-sektormodellen udviklet fra konkurrencens begreb og gennem inddragelsen af kreditten skal følgende konsekvenser af statsligt organiseret efterspørsel for en national $\varnothing$ konomi påpeges: Staten skaber en efterspørgsel til SIII ved hjælp af en værdimasse, der kan være skaffet gennem skatter og afgifter, gennem salg af værdipapirer, udstedelse af obligationer, tvungen opsparing, renter af anlægskapital, overskud af statsvirksomheder eller gennem låntagning på det internationale lånemarked og udvidelse af likviditeten ved hjælp af træk på nationalbanken (pengeudstedelse og ophævelse af låneloftet). Denne forøgede værdimasse som staten skaffer til veje gør, at det bliver muligt at realisere en langt større vardimasse end der faktisk skabes indenfor sektorerne.

Dette realiseringspotentiel gør det muligt at markedsværdiniveauet holdes kunstigt oppe gennem statens efterspørgselspres, således at der i visse brancher - nemlig hjemmemarkedsbrancherne især - realiseres enorme ekstraprofitter, fordi markedsprisniveauet justeres efter de mindste og mindst produktive virksomheder.

Skabelsen af denne store masse »falsk social værdi« presser prisniveauet hos nationen op og invaliderer dens muligheder på det internationale marked:

Eksistensen af visse SI- og SII-brancher, der bliver statens »hofleverandører « til et særligt favorabelt pris- og dermed profitniveau, medfører, at gennemsnitsprofitraten ikke udlignes i samfundet, fordi eksportindustrien simpelthen ikke kan realisere sine produkter til så høje produktionspriser. Konsekvensen af statsinterventionismen viser sig da først og fremmest $i$ en forværring af betalings- og handelsbalancen, $i$ en opskruning af omkostningsprisen og i et fald i profitniveauet i eksportbrancherne i sammenhæng med en svækkelse af valutaens position.

Det stigende prisniveau i samfundet fordyrer naturligvis også importen og udløser politiske uroligheder ved at undergrave reallønnen samtidig 
med et stærkt pres fra eksportindustrien om ikke at forhøje den nominelle $1 \varnothing n$.

Staten presses altså ind i et dilemma, om den skal forhøje sin efterspørgsel proportionalt med importens stigende værdi, eller om den skal gribe til politiske løsninger for at få lagt et lønloft, da en af hjemmemarkedets hovedsektorer jo vitterligt er SII, og da det høje prisniveau her trækker priserne på de importerede SII-varer op.

For den statslige efterspørgsel har foruden at skabe et højt prisniveau i hjemmemarkedets SI og SII også gennem stabiliseringen af dette prisniveau opretholdt eksistensen af en række lavproduktive og arbejdsintensive virksomheder i brancherne. Denne tendens er blevet accentueret af den $\emptyset$ gede kreditmasse, således at en række industrikapitaler og handelskapitaler er blevet reddet fra falitten gennem en udstrakt og ofte tabgivende kreditgivning gennem en ukritisk forøgelse af såvel anlægs- som driftskreditter. Således har statens altså gennem sine »anti-rationaliserende « virkninger (konkurrencebegrænsende) medvirket til en forøgelse af beskæftigelsen, der har stillet arbejderklassen stærkt i forhandlingssituationer og dermed forhindret det løntryk som produktionsprisniveauet i industrien delvis kræver. Det stigende produktionsprisniveau er på hjemmemarkedet med dets stigende virkning på importen af alle varetyper gør også reproduktionen af fix kapital vanskelig, ved bestandig at forringe værdien af akkumulationsfonden og ved at overhale afskrivningsprocenten. Det stigende produktionsprisniveau vil altså blive presset yderligere i vejret af stigningerne $\mathrm{i}$ værdien af den fixe kapital. ${ }^{49}$

Det er tydeligt at statsinterventionismen generelt må siges at have negative virkninger, fordi den forringer landets rolle på verdensmarkedet og dermed fjerner grundlaget under sine egne eksistensbetingelser: stabiliseringen af den politiske overbygning. For stabiliseringen udhules når staten ikke længere kan forsyne arbejderklassen med den fornødne »materielle « kompensation for undertrykkelsen.

Også forøgelsen af skattebyrden på arbejderklassen som følge af statsinterventionismens financeringsbehov medvirker til at bringe den stiltiende socialkontrakt i fare. Om skatterne på arbejderklassen skal opfattes som taget fra den variable kapital, altså som en reduktion i arbejdernes revenu, eller om den skal opfattes som en forøgelse af den variable kapital og dermed som en forringelse af merværdiraten er et def initorisk problem, der kræver en bestemmelse af reallønnen for at kunne løses. På niveauetfor-kapitalen-i-dens-realitet viser det sig, at en forøgelse af skatteprocenten vil medføre en forøgelse af produktionspriserne ved at forøge omkostningsprisen og dermed sætte det markedsværdiniveau i vejret på baggrund af hvilket en given ekstraprofit kan realiseres, hvis vi tænker os reallønnen som konstant. Ved faldende realløn kan en forøgelse af personbeskatningen godt forløbe med konstante produkti- 
onspriser, men der kræves givetvis politiske indgreb for at en sådan situation kan opretholdes, hvilket for $\varnothing v$ rigt også hører med til billedet af statsinterventionismen, hvis vi tager lande som USA, Holland, England og også - omend i mindre grad - Danmark. Om stigende personbeskatning ved konstant realløn er identisk med det, der på niveauet-for-kapitalen-i-almenhed hedder et fald $\mathrm{i}$ merværdiraten, på kortere sigt, er afhængig af den virkning på den statslige efterspørgsel som de stigende produktionspriser medfører, og af akkumulationstempoet og akkumulationssammensætningen.

\section{1.b. Akkumulationsimperativet}

Som allerede nævnt vil statsinterventionismen over kort tid kunne modificere tesen om profitratens faldende tendens ved at opretholde en efterspørgsel, der bremser det akkumulationsimperativ, der er indbygget i den kapitalistiske samfundsform. Gennem et heterogent gennemsnitsprofitniveau til fordel for hjemmemarkedsbrancherne vil store ekstraprofitter og eksistensen af en række lavproduktive foretagender kunne opretholdes. Statsinterventionismen er altså egentlig i modsætning til konkurrencens begreb, fordi den sænker produktivitetsniveauet og forhaler den generelle indførelse af højere produktivitetsgrænser, (minimumsgrænser).

Forudsætningen for profitratens faldende tendens er jo - hvilket man ofte glemmer fordi man tænker profitratefaldet på niveauet-for-kapital-i-almenhed p.gr. af denne teses lighed med akkumulationstesen i bd. I af Das Kapital - dannelsen af en gennemsnitsprofitrate i hele samfundet, dvs. en udglatning af forskellene i ekstraprofitter brancherne imellem. Men statsinterventionismen forhaler dette.

Den forhaler også konkurrencen mellem arbejderklasse og kapitalistklasse ved at udvikle et socialsikkerhedsnet for arbejderklassen såvel som et sikkerhedsnet for profitten.

Hvor statsinterventionismen synes afgjort til fordel for visse kapitalgrupper, nemlig for enkeltkapitalerne i hjemmemarkedsbrancherne, der leverer varer til SIII, og for SIII selv, så er det tvivlsomt om den er til fordel for de mindre handelskapitalister (grossister og detailhandlere), fordi beskatningen falder hårdt her, og fordi mange af disse virksomheder er for små til at udnytte kreditmulighederne rigtigt.

Om statsinterventionismen har været til fordel for arbejderklassen er et vanskeligt spørgsmål, men givet er det at bremsningen af akkumulationen til fordel for intensiveringen af arbejdet, som eksistensen af mange små virksomheder indebærer, ikke har været til fordel for de enkelte arbejdere.

Endelig har statsinterventionismen skabt en gruppe af ansatte i SIII, hvis eksistens direkte er båret materielt af interventionen, og disse gruppers interesser er selvfølgelig positivt forbundet med statens aktivitet.

Selvom statsinterventionen nok har forøget totalmerværdimassen i forhold til hvad en ren konkurrencekapitalisme ville have præsteret ved samme tekniske niveau, så er det betvivleligt, om interventionen har været til fordel for kapitalismen: for hvor den ujævne udvikling af produktiviteten indenfor brancherne, 
således, at få store firmaer producerer med stort og udviklet kapitalapparat mens hovedparten producerer med et mindre og dårligt, har givet store ekstraprofitter, så har hele udviklingen medført en internationalisering af kapitalen, der efterhånden gør nationalstaten til en mindre effektiv vogter af kapitalens interesser. Det betyder, at en række nationale kapitaler kommer i klemme p.gr. af for lav produktivitet, hvilket igen virker tilbage på det nationale system som en trussel for stabiliten. Måler vi derimod statsinterventionismen med »planøkonomiske« alen, så er det tydeligt, at dens resultat er et enormt ressourcespild på grund af den »irrationelle « udvikling af produktiviteten indenfor brancherne. Hvor Mattick og Cogoy sikkert har ret i deres konklusioner på længere sigt, så er det dog forkert uden forbehold at konkludere, at SIII's eksistens er identisk med en totalreduktion af merværdien i SI og SII identisk med produktværdien af SIII. Thi først gennem inddragelsen af konkurrencens niveau, altså loven for dannelsen af gennemsnitsprofitraten og produktionspriserne viser det sig hvordan loven for den kapitalistiske akkumulation sætter sig igennem på baggrund af eksistensen af en relativ stærk stat i senkapitalismen.

\subsection{Statens ikke-selektive efterspørgsel og kredit}

Det er karakteristisk for statsinterventionismen, at den i ringe grad søger at styre sine kreditter og sin efterspørgsel i retning af givne kapitalfraktioner, en holdning der netop forkastes af den borgerlige stat selv i dens brud med de tidligere former for statsinterventionisme efter krisen 1974. Staten skelner altså ikke mellem kreditter til industrikapital og til handelskapital før 1974. Indtil 1-1-1974 var låneloftet for finanslån i udlandet 5 millioner kr. for aftaler truffet $6 \mathrm{mdr}$. før eller for kontraktlige forpligtelser gældende $12 \mathrm{mdr}$. frem. De eneste investeringer, der ikke måtte tages lån til var byggeanlæg, financering, leasing og holding, ellers var låntagningen fri.

Statens midler til indgreb i $\varnothing$ konomien var altså begrænset til en generel penge- og finanspolitisk stramning, der helt klart også og måske især ramte eksportindustrien og industrikapitalen $\mathrm{i}$ almindelighed ved at presse renten opad, og til indkomstpolitiske indgreb.

Således ligger der i hele Keynes' pespektiv en manglende forståelse for hvilke typer investeringer, der gavner samfundet som helhed, ja Keynes har faktisk ikke udviklet et totalkapitalbegreb, men er bundet til perspektivet for enkeltkapitalen, der betragter alle investeringer med afkast som »produktive« og renten som fjende nr. 1.

Det er karakteristisk for »multiplikator-effekten « - et begreb, der vel mere end noget andet udtrykker keynesianismens essens - at dette begreb ikke indeholder nogen konkretere forestilling om hvilke typer kapitalanlæg der ville gavne væksten. Her opfattes »indtægtsskabende« investeringer som produktive, m.a.o. en ren reproduktion af den trinitariske formels illusioner. Virkningerne af statsinterventionismen er da også afgørende bestemt af SIII's pro- 
duktions særlige karakter: er der som i Del 1 tale om byggeriet, så vil dele af denne produktion være produkton for arbejderklassen, mens en anden del vil være offentligt byggeri.

Produktionen for arbejderklassen indgår i SII og den statslige efterspørgsel vil her have den virkning, at den stabiliserer markedsværdiniveauet, men det er ikke sikkert at den vil forringe akkumulationsfonden i SI og SII. Det er nemlig klart at statslig efterspørgsel også på reproduktive goder vil have en samfundsmæsig effekt, et forhold er slet ikke kan tænkes i Cogoys fremstilling.

Byggeri for staten $\mathrm{i}$ form af administrationsbygninger vil derimod forøge markedsværdierne i SI og SII både ved at forøge efterspørgslen og ved at indskrænke akkumulationsfondens reproduktive form i disse sektorer (som Cogoy altså påpeger).

Disse virkninger er igen afhængige af hvorfra staten får sine indtægter: får den dem fra beskatning af kapitalistklassen, så er der i første tilfælde tale om en omfordeling af efterspørgslen fra visse kapitalgrupper til andre, staten allierer sig da sporadisk med visse enkeltkapitaler, men totalkapitalen påvirkes ikke.

I det andet tilfælde vil både enkeltkapitalgrupper og totalkapitalen forfordeles, hvis efterspørgslen financeres af skattepenge.

Stammer efterspørgslen derimod fra lån i udlandet vil virkningen først følge senere alt afhængig af de former hvorunder låntagningen udlignes. Den umiddelbare virkning vil være bestemt af renteniveauet og betalingsfristen, og af hvilke former for produktion lånerne anvendes til at skabe efterspørgsel på. Er der tale om det første tilfælde her ovenfor vil kreditten ikke have andre virkninger end en forøgelse af markedsværdiniveauet og ekstraprofitterne hos visse kapitaler, fordi der gives mulighed for at realisere mere værdi end der produceres. Renterne vil her fordeles over hele samfundet og udgøre et afbræk i totalmerværdien.

I det andet tilfælde vil det forhold, at efterspørgslen er financeret af et lån i udlandet, blot forstærke den allerede konstaterede virkning.

Virkningen på profitten i samfundet af denne efterspørgsel er altså i sit negative aspekt indirekte: det stigende markedsniveau i hjemmemarkedsindustrien belaster konkurrenceevnen på verdensmarkedet, og svækker låne- og eksportmulighederne og dermed grundlaget for statsinterventionismen. Cirklen er ond.

Heroverfor har staten kun en mulighed: at bremse efterspørgslen. Men for at kunne gøre dette må den gribe aktivt ind i betingelserne for visse revenukilders eksistens, nemlig arbejdskraftens. Staten må altså bryde illusionen om fællesinteresserne, der rummer særinteresser i sig, og det gør den nødigt. Derfor de strålove for profit- og avancestop, der indførtes samtidig med indgrebene mod arbejderklassen i foråret 75 .

Men her er statens aktionsgrundlag allerede ved at forskyde sig fra illusionen om revenukildernes forenelighed over i forestillingen om fællesskabet som en organiseret forretning, hvis identitet skabes i forholdet til udlandet, og hvor revenukilderne optræder som omkostningsfaktorer samtidigt med at de fungerer som krav på indtægt proportionalt med deres størrelse. 


\subsection{Staten og udbuddet}

Statsinterventionen sætter sig ikke alene igennem via skabelse, stabilisering og forøgelse af efterspørgsel, men også gennem en skabelse, stabilisering og forøgelse af $u d b u d$.

Stimuleringen af udbuddet sker direkte gennem investeringer, investeringsstøtte og favorable lånemuligheder, samt gennem en høj afskrivningsprocent.

»Udligningen af værdier til produktionspriser (Kostenpreisen) sker kun derigennem, at den enkelte kapital fungerer som en med sin egen størrelse proportional del af klassens totalkapital, og at klassens totalkapital fordeles over de forskellige specielle brancher i forhold til produktionsbehovene. Dette sker gennem kreditten ${ }^{50}$

Staten bliver således en nødvendighed for dannelsen af produktivitetsniveauerne i brancherne, fordi den alene - gennem garanti - kan skaffe den kreditmasse som akkumulationen på nationalt og internationalt plan kræver.

Det er derfor et direkte udtryk for statens manglende handlemidler og for dens politiske blokeringer - snarere end for dens manglende indsigt - når den tager pengepolitiske midler i anvendelse til at bremse kreditten, fordi den derved bremser for både industrikapitalens og handelskapitalens akkumulation, hvor kun den sidste af produktivitetshensyn burde bremses, og den første som grundlaget for $\varnothing$ konomisk vækst - burde befordres. Når staten derimod 1-1-1974 begrænser låntagningen i udlandet til anlægsinvesteringer og dermed udelukker lån til driftskapital ${ }^{51}$ så er der tale om en selektiv kreditpolitik og dermed om et brud med den trinitariske formels præmisser: en formel ligestilling af kapitalformerne på totalplan, (se fremme), til fordel for en mere rationel aktion i forhold til de væsenslove, der styrer det kapitalistiske samfund.

Statsinterventionismens relative ikke-selektive kreditpolitik har - dens ofte stramme karakter til trods - haft den virkning, at den har kunnet fremme spekulation uden at staten har kunnet kontrollere det.

Herved uddybes modsætningen mellem industri- og rentekapital. For statens udbudsskabende- og dermed produktionsprissænkende muligheder - er helt afhængige af dens muligheder for at fordele kreditten på de enkelte kapitalfraktioner. Derfor indebærer kreditforøgelsen ikke med nødvendighed nogen stigende produktivitet i samfundet, altså en forbedring af handels- og betalingsbalance, men kan føre til forøgelse af spekulationen, af obligationsudstedelsen m.h. på anskaffelsen af penge til ikkereproduktive formål, driftskreditten og af afbetalingshandlen. Forøgelsen af kreditten gennem en diskontosænkning f.eks. behøver altså ikke føre til stigende udlånsvirksomhed til industrien, etc. Keynesianismens

50. Theorien über den Mehrwert, bd. III, s. 508, min overs. OFK. »Produktionspriser« hedder ofte i Theorien über den Mehrwert »Kostenpreise«.

51. Danmarks nationalbank, beretning og regnskab, 1974, s. 81-82. 
tese om livkiditets- og kreditforøgelse (den blander ofte de to forhold sammen) som et middel til samfundsmæssig vækst er således absolut ikke noget probat middel med mindre andre betingelser er tilstede. (Hvilket Keynes for $\emptyset$ vrigt selv var ganske på det rene med, for ham var opsparing og investering jo netop en ideel, ikke en faktisk, identitet.)

\subsection{De subjektive illusioner og statsaktivitetens grad af rationalitet}

Det fremstillede peger henimod det opgør med statsinterventionismens traditionelle former, der indledtes af venstreregeringen på baggrund af krisen.

Pengepolitiske stramninger, indførelsen af mere selektiv kredit, indkomstpolitikken, nulstillingen af pristallet og bygge- og anlægsstoppet, disse forhold viser at det politiske klima giver mulighed for andre aktionsformer. Udviklingen af en ny totalforestilling for statslig aktion: forestillingen om samfundet som en »forretning « hvis interesser i store træk falder sammen med industri - og her især eksportkapitalens, udgør delvis et brud med det fællesskabsbegreb, der følger af den »trinitariske formel«.

De regerende partiers og organisationernes indsigt i nationens afhængighed af verdensmarkedet for opretholdelsen af det kapitalistiske system gør en mere magtpræget statslig politik mulig, hvor der bl.a. spares gennem en reaktion mod politisk mindre magtfulde grupper: uddannelsess $\emptyset$ gende, etc. og mod meget brede og derfor også politisk magtesløse grupper såsom »forbrugerne«.

Staten handler her på en anden totalitetsopfattelses grundlag end det tidligere var tilfældet: revenukilderne sideordnes ikke længere på totalplan, men visse aspekter af revenukilden »kapital« fremdrages som afgørende for helhedens beståen: industri- og eksportkapital.

Dermed brydes med keynesianismens identitet mellem indtægtsforøgelse og økonomisk vækst. Vækst er kun forenelig med stigninger i visse former for indtægt.

Således kan staten på baggrund af sin nye legitimationsbasis: at revenukildernes opretholdelse og kontinuitet er afhængig af nationens position på verdensmarkedet (understreges naturligvis yderligere af medlemsskabet af EF) gribe ind over for revenukilden »arbejdskraft « og overfor fraktionen »handelskapital « af revenukilden »kapital «.

Også overfor ejerne af jord - hvor man dog næppe kan tale om revenukilde i samme grad som Marx gjorde det idet han forudsatte modsætningen mellem jordejere og forpagtere - gennem diskontostigninger, der får rente på obligationer til at stige, kan staten gribe ind.

Endelig er der også tale om indgreb overfor forbrugerne som helhed gennem begrænsningen af forbrugskreditterne.

Statens aktionsformer kan altså ikke længere ganske rummes i begrebet for den trinitariske formel, men må - selvom statens eksistensgrundlag i vis udstrækning stadig er denne »formel«, da kapital og arbejde stadigt fremstil- 
les som formelt ligestillede »produktionsfaktorer «, hvis værdi begrundes i knapheden på dem - konkretiseres med henblik på de fraktioner, der følger af kapitalens formspecificeringer på niveauet-for-kapitalen-i-densrealitet: industrikapital, handelskapital, pengekapital, rentekapital.

Den borgerlige stat kan nu erkende og handle ud fra indsigten i modsætningerne mellem industri- og handelskapital: indførelsen af restriktionen på låntagning i udlandet til andet end anlægskreditter viser dette tydeligt, og også den stiltiende aftale mellem nationalbanken og privatbankerne om at begrænse driftskreditterne.

Derimod står det stadigvæk ikke i statens magt at gribe restriktivt ind overfor rentekapitalen, fordi en udvidelse af kreditten fremmer efterspørgslen også selvom den anlægges i fast kapital, mens et lavt kreditloft forhøjer renten, forhold, der begge har negativ virkning på eksportkapitalens betingelser. Påvirkningen af renten er nemlig uløseligt bundet til obligationsmarkedet således, at en kreditstramning af hensyn til det ekspanderende prisniveau gennem f.eks. nationalbankens salg af obligationer vil medføre en rentestigning p.gr. af den faldende likviditet samtidig med at kursfaldet på obligationer (sammen med den stigende rente) kan få alvorlige politiske konsekvenser fordi store dele af vælgerskaren er parcelhusejere og derfor integreret i obligationsmarkedet.

Samme virkning har en stigning i diskontoen og en stramning af låneloftet: det hæmmer langtidskreditter og dermed anlægsinvesteringerne og således nationens position på verdensmarkedet. Den moderne borgerlige stats problem er på mange måder rentekapitalen som den, jo mere nationen integreres i verdenskapitalismen og kreditten udvikles, bliver mindre og mindre herre over.

Men problemet er, om det borgerlige samfund ud fra sin legitimationsbasis overhovedet kan gribe ind overfor rentekapitalens interesser, fordi rentekapitalen er prototypen på kapital i egenskab af revenukilde: betvivlelsen af rentekapitalens eksistensberettigelse ville være ensbetydende med en åben tilbagekaldelse af kapitalens ret som revenukilde. Thi i rentekapitalen fuldendes konkurrencens facadeillusion i yderste abstrakte potens: kapitalen som abstrakt, ustoflig værdi afkaster værdi proportionalt med sin størrelse.

Rentekapitalen er i det borgerlige univers en "produktiv« størrelse og må være det, fordi kapitalens eksistensgrundlag er »knapheden«: både rente og profit er dybest set begrundet i kapitalens sjældenhed i kombination med dens samfundsn $\varnothing$ dvendighed. ${ }^{52}$

Institutionaliseringen af knaphedsdoktrinen i og med revenukildebegrebet får rentekapitalen til at fremtræde som noget produktivt: I renten »fixeres produktionens resultat som en konstant og derfor forudsat betingelse for denne (produktionsmåden) og endda som konstant egenskab ved de tingslige (sachlichen) produktionsbetingelser $\ll^{53}$.

52. Om den subjektive værditeoris illusioner, se Mehrwert, nr. 1.

53. Theorien über den Mehrwert, bd. III, min overs., Marx' fremhævelser, OFK. 
At staten for øjeblikket synes at identificere sig selv med eksportkapitalen og dermed med industrikapitalen betyder ikke at den stiller sig i eksplicit modsætning til rentekapitalen, for det ville være ensbetydende med en fornægtelse af dens eget væsen, men den kan fremstille rentekapitalens fortsatte produktivitet som afhængig af industrikapitalens fremgang. Selv om dette naturligvis ikke gøres ved at rentens logiske afhængighed af gennemsnitsprofitratens absolutte størrelse og den fungerende kapitalists relative mangel på profit ekspliciteres.

Hertil kommer desuden, at rentekapitalen i sig selv heller ikke er nogen enhed, men igen må spaltes op i forskellige interessefraktioner, hvilket eksistensen af rentemarginalen tydeligt viser: der findes både sparere og så dem, der lever af at låne disse opsparede midler ud.

Hvad er nu - må vi til sidst spørge - grænsen for den »nye « type statsindgreb ny i Danmark siden krigen, men ikke i forhold til Holland, England og USA.

Grænserne for statens indsigt i den kapitalistiske verdenssammenhæng, i kapitalismens »rationalitet « (immanente), er både sat af dens aktørers interesser og deres handlingsmuligheder. Interesserne er for hovedparten de abstrakte fællesinteresser i opretholdelsen af kapital og arbejde i deres nuværende form, men handlingsmulighederne er bestemt af konjunkturerne på verdensmarkedet, af det politiske klima og af de midler, som statens legitimationsbasis tillader, altså af meget »generelle« midler.

Ifølge sit væsen som både kapitalisternes $o g$ arbejdernes stat kan staten aldrig handle helt rationelt ud fra det virkelige reproduktivt betemte totalitetsbegreb, men den kan idag - presset til det af statsinterventionismens svagheder - nærme sig en forståelse for et totalitetsbegreb. Det ser således ud: Alt det arbejde, der gavner samfundet skal høre under følgende tre grupper:

I) Arbejde, der skaffer varer eller tjenester til eksport, og som ikke medvirker til en forringelse af handelsbalancen. (Hvor akkumulationsfonden stammer fra spiller ingen rolle).

II) Arbejde, der begrænser det private og offentlige forbrug.

III) Arbejde, der begrænser totalomkostningsprisen.

Bruddet med den mere generelle formel: alt indtægtsskabende arbejde fremmer væksten, er tydelig. Der er blevet plads til en forståelse for at totalkapitalen i forhold til udlandet stilles dårligere, jo mere revenukilderne og revenuerne vokser, fordi de på verdensmarkedet direkte indgår som dele af eksportkapitalens omkostningspris:

V og K = IK's og HK's, PK's og RK's profitter.

Grænserne for statens aktion til kapitalismens stabilisering ligger altså i kapitalen selv: i modsætningen mellem kapital og arbejde og mellem kapitalfraktionerne, de er på engang de samfundsmæssige gruppers indtægtskilder og de faktorer, der konstituerer gennemsnitsprofitraten. 
Det er her gennemsnitsprofitraten, der lader eksportindustriens forfordeling gennem statsinterventionen fremtræde for enkeltkapitalen i eksportindustrien.

Gennemsnitsprofitraten sætter sig her igennem via et krav fra eksportkapital-fraktionen om en bremsning af de faktorer, der hæver omkostningsprisen og sænker profitrateniveauet i disse brancher (eksportkapitalbrancherne) fordi produktionsprisniveauet ligger fast på verdensmarkedet.

Dette krav sætter sig igennem som et generelt krav til statsinterventionismen som helhed, nemlig kravet om offentlige besparelser og om indkomstpolitiske løsninger.

Disse krav er jo også blevet opfyldt efter 1973, hvilket loven om forlængelse af de kollektive overenskomster og aftaler med bygge- og anlægsstoppet viser.

Men her antydes en ny dimension for gennemsnitsprofitratens funktionsmåde: gennemsnitsprofitrten sætter sig ikke nødvendigvis igennem via en overførsel af kapital fra en branche til en anden - således som Marx primært tænkte det - men den sætter sig også igennem via staten: ud fra sin samfundsmæssige nøgleplacering som nationens repræsentant på verdensmarkedet og dermed som et af grundlagene for statsinterventionismens mulighed i det hele taget kan eksportindustrien stille krav til samfundet som helhed, der effektueres af staten gennem begrænsninger i efterspørgslen og gennem politiske løsninger på arbejdsmarkedets konflikter.

Gennemsnitsprofitraten i samfundet dannes altså ved at staten bryder med revenukildebegrebet på visse punkter og direkte opfatter disse kilder som dele af totalomkostningsprisen overfor udlandet.

Den ophævelse af konkurrencens skarpeste former som statsinterventionismen indebar i sin milde form - naturligvis er der ikke tale om en ophævelse af konkurrencens begreb, da dette jo regulerer hele virkningen af statsefterspørgslen gennem markedsværdiniveauet og eksistensen af ekstraprofitter - revideres altså via verdensmarkedet, idet eksportkapitalen kan stille kravet til samfundet som helhed om en sænkning af markedsværdiniveauet på hjemmemarkedet.

Vi ser altså, at statsinterventionismen klart er underkastet konkurrencens begreb og dermed kapitalens begreb, og at grænserne for statsinterventionismen netop ligger i loven for dannelsen af gennemsnitsprofitraten og produktionspriserne, nationalt og i internationalt sammenhæng.

Staten befinder sig altså virkelig i et dilemma: eksportens succes er betingelsen for statsinterventionismens $\varnothing$ konomiske mulighed, samtidigt med at netop eksportindustrien befinder sig i politisk modsætning til så godt som alle andre grupper og klasser i samfundet, selvom det naturligvis kun er på overfladen, da eksportindustrien jo indgår konstituerende som en del af IK og dermed konstituerende i skabelsen af gennemsnitsprofitraten hvoraf de resterende kapitalfraktioner lever. Betingelserne for eksportsucces er altså politisk uro og betingelsen for politisk ro ligger i eksportindustrien... 
Konsekvenserne af statens mere restriktive politik er en forringelse af arbejderklassens realløn og af dens arbejdsvilkår.

Det er en underbygning af profitratens faldende tendens - som den »milde « statsinterventionisme jo kunne skubbe lidt på afstand - gennem en sænkelse af markedsværdiniveauet og dermed en reduktion af en række ekstraprofitter og destruktionen af en række enkeltkapitaler.

Virkningen af den »strenge« intervention er afhængig af konjunkturerne på verdensmarkedet, altså af mulighederne for eksport ved et givet produktivitetsniveau: hvor meget skal industrien akkumulere for at klare sig, etc.?

Her får Matticks teser fuld gyldighed: for tendensen går her i retning af en formindskelse af totalmerværdien relativt til totalkapitalen og dermed vil akkumulationen og statens indtægtsmuligheder bremses.

Samfundet bliver da ekstrafølsomt overfor de mindste udslag i merværdiraten, hvilket forøger presset på arbejderklassen. Stigningen i produktivitet og det relative fald i anlæg af produktive kapitaler som følge af stigningen i minimumsgrænsen for kapitalanlæg på grund af de faldende produktionspriser vil da forøge reservearmeen i form af arbejdsløse og uproduktivt ansatte, hvilket yderligere vil begrænse merværdien - med mindre staten begynder at lukke op for posen - og dermed få modsætningerne mellem kapitalist- og arbejderklasse til at eskalere.

Frederiksberg, 7-12-1975.

Fortscettelse fra side 184

tellektuelles rolle identificeret med at gøre den marxistiske videnskab (i fagkritisk form!) til det formidlende led i »alliancepartnerskabet med arbejderklassen«. At væsentlige skranker herfor ikke blot ligger $\mathrm{i} \gg$ teoriens isolation «, men dels i den kapitalistiske arbejdsdelings historiske konstitution, dels $\mathrm{i}$, at arbejderbevægelsen i dag ikke har udviklet sig samfundsmæssigt som klassebevagelse, synes ikke at bekymre HJN. Endnu mindre lægger han op til en forståelse af, at i det omfang arbejderklassen kan betegnes som det kapitalistiske samfunds revolutionære kraft, må det være begrundet $i$ dens erkendende praksis indenfor det borgerlige samfund, og ikke i dets historisk objektive, (men endnu ikke erkendte) interesse i omvæltningen af de kapitalistiske produktionsforhold.

De marxistiske intellektuelles politiske rolle lades på baggrund heraf i bedste fald udiskuteret, i værste opstilles en i det borgerlige samfund utænkelig situation, (s. 85:) »hvor der ingen principiel forskel er på intellektuelle kommunister og kommunistiske arbejdere.«

Januar 1976 


\title{
KAPITALBEVAEGELSE - OG KLASSEBEV/EGELSE?
}

\author{
Susanne Possing
}

\section{Anmeldelse af Hans Jørn Nielsen: Bevidsthedskonstitueringen $i$ kapitalforholdets sociale proces. Til en fremstilling ud fra arbejder- standpunkt, i: Den jyske historiker nr. 41975}

Hans Jørn Nielsen har skrevet sin artikel med det eksplicitte formål at bidrage til en analysestrategi for historiske unders øgelser af arbejderklassens bevidsthed og kamperfaringer. Hermed placerer den sig centralt i den marxistiske diskussion i dag. For det første forholder den sig til de teoretiskmetodiske problemer omkring tilgangen til studiet af »arbejderklassens kamphistorie«. Dette implicerer her dels den videnskabsteoretiske diskussion om kritikken af den politiske $\varnothing$ konomis status og gyldighedsgrænser, dels forholdet mellem $\varnothing$ konomi og politik, herunder den senere tids »objektivisme subjektivisme «-disput blandt 'kapitallogisk' orienterede marxister, og endelig spørgsmå- let om studenter/akademikeres forhold til arbejderklassen.

Artiklen falder i tre hoveddele: 1) Hovedafsnittet som præsenterer HJN's fors $\emptyset \mathrm{g}$ på syntetisering mellem kritikken af den politiske $\varnothing$ konomi og en teori om klassekampens udvikling (arbejderstandpunktudgangspunktet), 2) en kritik af SOFI's og Ole Marquardt's ansatser til analyse af forholdet mellem konjunkturbevægelse og klassebevidsthed og 3) en gennemgang og diskussion af Proletarische Front's vigtigste arbejder.

I denne anmeldelse vil jeg specielt koncentrere mig om HJN's kapitalismeopfattelse, i sammenhæng hermed om hans 
fors $\emptyset \mathrm{g}$ på teoretisk at sammenkoble kapitallogik og klassekamp i form af arbejderstandpunkttesen og endelig vil jeg diskutere den fagkritik-opfattelse, der im- og eksplicit kan drages af (PF's og) HJN's forsøg på at skabe en teoretisk formidling mellem teori og praksis (eller mellem universitetsteoretisk marxisme og arbejderklassens eksistens og politiske udvikling).

\section{II}

Det centrale problem i artiklen er den $»$ almene bestemmelse af den videnskabelige fremstilling af den samfundsmæssige væren som bevidstheden må beskrives $\mathrm{i}$ forhold til.« (s. 80). HJN's intension er således i sin abstrakte formulering identisk med en stor del af arbejdet blandt fagkritiske/marxistiske studenter og akademikere for tiden: dels at opsøge de teoretisk centrale kategorier for en historisk-empirisk anknyttet analyse (det såkaldte realanalyse-problem), dels at bidrage til analyser af arbejderbevægelsens organisationer og politiske udvikling som en integreret del af analyserne af kapitalens historiske reproduktionsproces.

HJN tager sit udgangspunkt i den marxske teori. Om denne hævder han, at den - i realabstraktionernes form - fremstiller »de almene logiske bevægelseslove, der gør sig gældende for rigdommens former $($ s. 80) i det kapitalistiske samfund. Imidlertid mener han, at »den samfundsmæssige væren« falder uden for Marx' fremstilling, thi denne er kun en almen-logisk teori og kan derfor ikke omfatte den samfundsmæssige væren, som »kun kan forstås historisk-specifikt « (s. 80). For HJN må klasseforholdet mellem kapital og lønarbejde placeres under kategorien »samfundsmæssig væren« (i modsætning til den abstrakte produktionsrelation, som fremstilles i kritikken af den politiske $\emptyset$ konomi (!)). Bevidsthedsanaly- sen af arbejderklassens kampudvikling må derfor knytte an til de »formidlingsformer « som klasseantagonismen eksisterer i på den samfundsmæssige overflade. Der opereres i artiklen med en forestilling om, at den kapitalistiske produktionsproces (som iøvrigt anvendes i flæng om skiftevis den umiddelbare produktionsproces og skiftevis den kapitalistiske akkumulationsproces) følger bestemte love, som imidlertid er skjult for agenternes bevidsthed på samfundets overflade. I sin fremstilling fremhæver HJN specielt produktionsprocessen, som baseret på den abstrakte $\emptyset$ konomiske antagonisme mellem dødt og levende arbejde. Denne modsætning fremtræder på samfundets overflade som det politiske klasseforhold mellem kapitalistog arbejderklasse.

Parallelt hertil fremlægger HJN en Marxfortolkning, som går på at Marx i Kapitalen $i k k e$ har analyseret den samfundsmæssige væren, ikke har fremstillet kapitalens samfundsmæssige organisationsformer som de udvikler sig på samfundets overflade (højst i form af konkurrencen ml. enkeltkapitalerne i III. bind) og ikke har inddraget historiske og stoflige elementer i sin kapitalisme-analyse. HJN's model ser ud som følger:

Fra Marx har vi fået leveret analysen af kapitalakkumulationens indre lovmæssigheder, af det abstrakte akkumulationsimperativ. Marx har også udviklet konkurrencen som en »overfladefænomenal « formidlingsform for dette abstrakte valoriseringskrav. Parallelt hertil må vi nu udvikle klasserelationen (klassekampen), staten og verdensmarkedet som »formidlingsformer «, alle tre former for samme abstrakte kapitalproduktion, og former, hvis bestemmelse kræver historiske analyser.

Inden jeg går over til en egentlig indholdsmæssig kritik af den historieopfattelse, som kommer til udtryk i arbejderstandpunkt-tesen, vil jeg knytte nogle enkelte kommentarer til den forståelse af Kapitalens 
teoretiske status, som HJN her bringer til torvs.

HJN lægger med sin fremstilling op til en kritik af 'kapitallogikken', herunder af de begrænsninger, der ligger i at lægge kritikken af den politiske $\varnothing$ konomi til grund for historiske bestemmelser af 'overfladebevægelsernes' sociale forhold. Genstand for kritikken og HJN's teoretiske referenceramme er her tydeligvis den ret udbredte tendens $\mathrm{i}$ Marx-rekonstruktionen, som har centreret sig omkring diskussionen af analyseniveauerne og omkring spørgsmålet om, hvilken begrebslig 'afledningsstatus' de marxske kategorier i fremstillingen kunne tillægges (jvf. f.eks. store dele af statsteoridiskussionen og diskussionen omkring værdilovens omfangslogiske status). Det gennemgående tema har i denne del af det teoretiske arbejde været formidlingsproblemet mellem den almene fremstilling (Marx) og kapitalens historiske udvikling.

HJN forsøger nu en kritik af 'kapitallogikken', som tager sigte på at reducere denne til en logisk fremstilling, hvis teoretiske begrænsninger ligger i dens almene karakter. Hermed har han reelt overtaget væsentlige dele af denne tendens' teoriforståelse, som han kritiserer. For HJN er den marxske teori udelukkende en logisk fremstilling af kapitalens almene bevægelseslove og de værdimæssige gennemslagsformer, som værdiabstraktionen under kapitalistiske produktionsbetingelser sætter i det borgerlige samfund. Hermed reproducerer han en uheldig tendens blandt 'kapitallogikere' til at identificere kritikken af den politiske $\emptyset$ konomi med fremstillingen af de almene formbestemmelser, en tolkning, som ser bort fra den marxske analyses fremstilling af kapitalens historiske bevagelsestendenser. De »sociale forhold, der også implicerer brugsværdimæssige størrelser« (s. 81) må forstås som integreret i den marxske fremstilling. Når HJN derfor vil pege på at den historiske udvikling ikke blot kan forstås som værdiens bevægelser på samfundets overflade, udtrykker han et forhold, som allerede Marx forstod. Hans teoretiske diskussion bevæger sig derfor ikke meget ud over planet for bestemmelsen af teoriens gyldighedsområde, hvorfor hans formulering af bevidstheds-problemet ind i spørgsmålet om en formidling mellem den almene teori og den historiske udvikling på forhånd er en skæv problemstilling.

Det sagnomspundne 'realanalyseproblem', forstået som spørgsmålet om at formidle en overgang fra kritikken af den politiske $\varnothing$ konomi til bestemmelserne af den mangfoldige realhistoriske fremtrædelsesverden resp. fra de $\varnothing$ konomiske til de politiske analyser, bliver styrende for hans fremstilling. Arbejderklassens historiske udviklede positioner og kamperfaringer tages heroverfor ikke indholdsmæssigt op, endsige behandles i sammenhæng med de områder for denne klasses kamp, som akkumulationens gennemsættelsesproces historisk har aftegnet. Denne metodologisering er så meget desto mere problematisk som HJN prætenderer at bidrage til en formidling af arbejderklassens bevidsthedsudvikling. Artiklen er således også primært interessant, fordi den udtrykker en aktuel tendens i det fagkritiske arbejde, hvor de konkrete afdækninger af arbejderklassens erfaringsproces erstattes af et teoretiske hundeslagsmål om objektivisme ctr. subjektivisme.

Flere steder ser det ud som om HJN har forstået kapitalen Marx-nært som en historisk specifik rigdomsform, der udvikler sig ved til stadighed på samme tid at udvikle nye bevagelsesformer og nye skranker for sig selv (f.eks. s. 88 og 89). Ikke desto mindre lykkes det ham at reducere kapitalakkumulationens udviklingsproces til en een gang for alle fastlagt automatik. Således hedder det f.eks. s. 81: »Når vi analyserer klasserelationerne mellem kapitalistklasse 
og arbejderklasse har vi i forvejen bestemt disse som byggende på en specifik produktionsmåde: produktion af merværdi og dermed kapital. Vi kender i forvejen bestemmelserne omkring merværdiproduktionen. Vi kan da opsøge den klasseantagonisme der eksisterer på overfladen i mangfoldige former for angreb, forsvar, modangreb. Disse former er antagonistisk bestemt, men kan samtidig fungere som formidlingsformer for kapitalakkumulationens videre udvikling (ligesom konkurrencen).«

Det fremgår heraf bl.a., at HJN tillægger formidlingsformerne på samfundets overflade en drivkraftfunktion for kapitalakkumulationen, dennes modsigelser er sat (læs: bestemt af Marx) en gang for alle, mens det borgerlige samfunds udviklingsmotor ligger i virkeligheden selv! (læs: samfundets overflade). I denne næsten deterministiske model placeres merværdiproduktionen i et tilsyneladende »dyb « og kapitaludviklingen videre skæbne afgøres udenfor merværdiproduktionen, på den samfundsmæssige overflade. (Jvf. senere kritikken af HJN's opfattelse af kapitalens produktionsproces).

Hvis den kapitalistiske reproduktionsproces identificeres med $»$ kapitalens logiske forløb« (s. 88), må der naturnødvendigt opstå et formidlingsbrist mellem bestemmelsen af produktionsmådens almene bevægelsesform og dechiffreringen af de historisk specifikke skranker for kapitaludviklingen.

Løsningen på bristen finder HJN i arbejderstandpunktet: »Hermed menes ikke noget moralsk, men det simple forhold at ikke kapitalens logiske forl $\phi b$ lagges til grund for fremstillingen, men klasseantagonismens forløb i klassekonflikter...« (min fremhævelse). At dette opfattes som alternativerne kan kun betyde, at HJN opererer med et logificeret begreb om den marxske fremstilling (på trods af, at han andetsteds overtager PF's i sig selv meget rimelige påpegning af, at de marxske kategorier indeholder histori- ske elementer qua deres proceskarakter (cit. s. 108). Ellers ville han ikke kunne opstille en »fremstillingsstrategi«, der, som skitseret i ovennævnte citat fra s. 81, forudsætter, at kritikken af den politiske $\varnothing$ konomi er en udelukkende almen-logisk analyse, og at fremstillingsmåden i Kapitalen udtrykker en gradvist stigende nærhed til den virkelige historie. (jvf. s. 83-84 øv.) Kritikken af den politiske $\varnothing$ konomi er hermed reelt blevet reduceret til en metode, der skal bringes i anvendelse på virkeligheden.

\section{III}

I forlængelse af ovenstående kritik vil jeg nu diskutere arbejderstandpunkttesen, først med henblik på dens teoretiske brist og dernæst $\mathrm{i}$ forhold til dens politiske indhold og strategiske konsekvenser.

Når kapitalforholdets fremstilling i kritikken af den politiske $\varnothing$ konomi forstås ensidigt som et almen-logisk forhold, er det videre forståeligt, at problemet om hvorvidt bevidstheden omfattes af denne teori må trænge sig på som problem. Denne problemstilling mener jeg som nævnt er formuleret ahistorisk, og for at anskueligg øre kritikken vil jeg fremdrage et forhold, som forhåbentlig kan løfte kritikken af HJN ud over den sædvanlige pukken på en forkert teoriopfattelse. Det drejer sig om at reflektere de historiske grænser for det aktuelle fagkritiske arbejde.

De afgørende betingelser for teoriudviklingen forstås for tiden ikke som de historisk-aktuelle modsigelser i arbejderklassens organiserede kampe på fabrikken, som modsætningerne imellen enkeltkapitalerne og brancherne, i de statslige politikker osv., men forstås derimod som det intellektuelt formulerede krav om at give de historiske analyser et alment politisk indhold. Denne selvforståelse har naturligvis sin rationelle 
kerne af sandhed: dels er det teoretiske arbejde stadigvæk underlagt den kapitalistiske arbejdsdelings adskillelse af ånds- og håndsarbejdets produktion, dels fremstiller den indre sammenhang mellem økonomi og politik sig samfundsmæssigt endnu som en ydre adskillelse. Hermed er der også sat grænser for en overskridelse af, at det bliver teorien (kritikken af den politiske økonomi), der danner ensidigt grundlag for de områder, der tages op til behandling, og som former de kategorier, der udarbejdes. Den historiske eksistens af disse grænser bør imidlertid hverken bortabstraheres eller give anledning til »følgagtighed « $\mathrm{i}$ form af en reproduktion af det teoretiske arbejdes begrænsede muligheder.

For HJN er bevidsthedsanalysen og her specielt fremdragelsen af klasseantagonismen som konkret formidlingsform - som for mange af venstrebevægelsens fors $\emptyset \mathrm{g}$ på at studere arbejderklassens bevidsthed og kamphistorie - et sådant fors $\emptyset \mathrm{g}$ på at overskride teoriudviklingens historiske betingelser og give analyserne et politisk perspektiv og indhold. Jeg vil betegne det som udtryk for, at spørgsmålet om arbejderbevidsthedens udvikling forstås som et erkendelseseller kundskabsproblem, og ikke som et historisk praktisk problem. Klassekampen bliver - som mest fremherskende tendens blandt primærorganiserede marxister - i denne interesses kølvand opfundet som aktuel samfundsmassig bevægelse i sig selv, langt snarere end den opfattes i sin historisk-aktuelle skikkelse af ansatsvis og partiel klassebevægelse i dele af arbejderklassen.

Med disse bemærkninger til selve angrebsmåden på klasseudviklingen vil jeg vende tilbage til HJN's udformning af PF's arbejderstandpunkt-tese. Denne udtaler sig primært her om en i forhold til kapitallogikkens alternativ tilgang til afdækningen af bevidsthedsdannelsen i det borgerlige samfunds klasser.
Som nævnt i afs. II er det HJN's (og PF's) program at udvikle de historiske analyser med udgangspunkt i overfladebevægelserne som 'konkret-former' (se s. 108) (eller konkrete formidlingsformer for de abstrakte værdiformer). Allerede tidligere pegede jeg på den teoretiske forkortning, som præger HJN's begreb om samfundets overflade, ligesom jeg har nævnt den begrebsforvirring, som karakteriserer hans ret letbenede omgang med kapitalens akkumulationsproces og den umiddelbare produktionsproces.

Historiens drivkraft ligger i virkeligheden selv (=overfladen), er en af de sandheder, som HJN fortæller os. At kapitalakkumulationens indre lovmæssigheder udspiller sig udenfor denne overflade (=virkeligheden) må vi så leve med. Det kan i sig selv være lidt vanskeligt; helt umuligt bliver det, når HJN samtidig opererer med »den virkelige produktionsproces « og dens historiskspecifikke klasseantagonisme som en til konkurrencen sidestillet formidlingsform for merværdiproduktionens abstrakte antagonisme mellem dødt og levende arbejde. Lad os se lidt på, hvordan HJN når frem til dette.

Konkurrencen er sat som »det forhold, der driver kapitalens udvikling fremad. (...) I udviklingen af kapitalens indre lovmæssigheder har han dog samtidig vist, at en afskaffelse af konkurrencen ikke vil ophæve akkumulationsimperativet«. (s. 83). Hvis HJN havde opfattet den marxske akkumulations- og kriseteori som en fremstilling af kapitalproduktionens modsigelser og ikke som en deterministisk teori om 'det værdimæs.' resp. 'det stofliges' indflydelse på akk. processen (se bl.a. s. 82-83), ville han også vide at konkurrencen i det borgerlige samfund er en del af kapitaludviklingen gen og at den drivende motor for denne nødvendigvis må være kapitalakkumulationen; samtidig er konkurrencen formen for profittens fordeling mellem enkeltkapitalerne. 
Konkurrencen er hermed også forudsat kapitalens samfundsmæssiggjorte form, hvilket betyder, at kapital som samfundsform og produktionsmåde uden konkurrence er en historisk umulighed. Hvis det blot var fordi HJN syntes, det var interessant at fremhæve en banalitet som følgende: »Kapitalakkumulationen har sine indre lovmæssigheder og konkurrencen i sig selv kan ikke være eneste formidlingsform. Konkurrencens afskaffelse afskaffer ikke kapitalproduktio$n e n$ «, så var der ingen speciel grund til at interessere sig for det. Det er imidlertid ikke tilfældet. Faktisk viser det sig, at HJN er i færd med et neoricardiansk-lignende forehavende: nemlig ophøjelsen af konkurrencen som profitproduktionens fordelingsform til en af den $\emptyset$ konomiske udviklings bærende principper. Når nu »konkurrencen ikke kan være eneste formidlingsform « må vi på den samfundsmæssige overflade opsøge andre fremtrædelsesformer for »det abstrakte akkumulationsimperativ».

Her indføres så »klassernes indbyrdes forhold», staten og verdensmarkedet som sidestillede former. Forkortningen af akkumulationsbegrebet viser sig her i en ny skikkelse: For HJN er det akkumulationsprocessen, der er kapitalabstraktionens indhold, og denne proces kræver sine »konkret-former $«$. Det er imidlertid noget sludder. Under kapitalismen er det valoriseringsimperativet og værdien, ikke dens reproduktionsproces, som er realabstrakt. Kapitalakkumulationen forløber som en modsigelsesfyldt (dobbelt) proces af kapitalvalorisering og merværdirealisering; en proces, hvor enheden og indholdet etableres gennem kapitalens underlæggelse af de stoflige materielle former. Derfor må kapitalakkumulationen også altid være det konkrete resultat og forudsætning for akkumulationsimperativet, akkumulationsprocessen kan kun forløbe historisk i form af kapitalens subsumtionsbevægelse, og hverken klasseforholdet eller de andre nævnte »former« kan derfor have status af konkrete formidlingsformer herfor.

HJN adskiller det abstrakte akkumulationsimperativ fra dets realiseringsform og grundlag, og henfører yderligere denne dikotomisering af akkumulationsprocessen til henholdsvis den logiske bestemmelse i den almene teori og den historiske specifikke overfladebestemmelse i de historiske analyser. Det hænger rimeligvis sammen med, at han - trods sine udtalte intensioner om det modsatte - kun ser kapitalen ensidigt ud fra dens formsmæssige bestemmelse og dens værdimæssige side. Derfor bliver resultatet også en stiv logificeret kapitalsystematik: brugsvardi/de stoflige momenter identificeres med overfladens formidlingsformer, som igen ligestilles med den virkelige historie.

\section{IV}

Klasseforholdet er imidlertid nu den form, som får en særlig behandling, teoretisk sidestilles den med de $\varnothing$ vrige overfladeformer, men politisk fremhæves den som den vigtigste af kapitalproduktionens historiske realiseringsformer. »De to klassers antagonisme opsøges konkret historisk i den relation, der abstrakt hedder forholdet mellem dødt og levende arbejde. En sådan vurdering, der bygger på en vurderig af arbejdskampens reelle betydning og af kapitalistklassens strategi vil kunne få en indirekte strategiskpolitisk betydning.« (s. 108).

Denne omvending af det borgerlige samfunds specifikke produktions- og fordelingsrelationer og abstraktionen fra, at den kapitalistiske reproduktionsproces som almen rigdomsform qua sin immanente underlæggelsestvang implicerer en naturgroet regulering af klasserelationerne, giver på dette sted anledning til mindst to problematiseringer.

For det første kan man stille HJN spørgsmålet om, hvorledes han tager kon- 
sekvensen af sin egen fremhævelse af, at klassernes styrkeforhold kun kan behandles historisk - specifikt, og begrunder, hvorfor klasserelationen »er den centrale relation i dag under den fuldt udfoldede kapitalisme $\ll$ ? Begrundelsen findes ikke, tværtimod kan man finde følgende selvmodsigelser på dette spørgsmål: S. 81 erkender HJN sin »analytiske afkortning « fra »hele den samfundsmæssige produktionsog reproduktionsproces «, på den anden side opererer han med en (forsøgsvis i hvert fald!) teoretisk begrundet ophøjning af produktionsprocessen til nøglekategori ikke blot for bevidsthedsdannelsen, men rent faktisk for hele den samfundsmæssige udviklingsproces.

Forholdet er dette, at HJN bliver fanget af sin egen artikels relativt abstrakte tilgang og behandling af forhold, som rigtignok kun kan afdækkes ved at tage udgangspunkt i realhistorisk udviklede genstandsområder. Artiklen forfejler dermed sit sigte, i og med dens metodologisering af specifikt historiske gennemsættelsesprocesser. Den nuværende kapitalismes komplekse quasiintegration af statslige og fagforeningsmæssige kapital- og lønreguleringsfors $\varnothing \mathrm{g}$ for slet ikke at tale om verdensmarkedskonkurrencen og den internationale udenrigshandels ændrede betydning for den nationale kapitaludvikling sætter anderledes komplicerede krav til de historiske analyser, end det fremgår af HJN's artikel. Disse forhold må alle forstås som skranker for kapitalens totalsamfundsmæssige reproduktionsproces og hermed også - omend formidlet - for den kapitalistiske produktionsproces' historiske udvikling. Når HJN med arbejderstandpunktet placerer arbejdskampene som den øjensynligt primære skranke for den kapitalisiske udvikling, er han derfor ude på både et teoretisk og et politisk overdrev: »Der ligger bag denne opfattelse det standpunkt at den kapitalistiske produktionsproces' udvikling historisk bestemmes af det faktum, at kapitalens lovmæssigheder støder på arbejderklassen som levende subjekt.« (s. 89). Hermed har han bortabstraheret væsentlige modsigelser i den kapitalistiske reproduktionsproces' historiske udviklingstendenser, og selv om han selv hævder at arbejderstandpunktet ikke er moralsk begrundet, er det svært at se, hvor argumentationen når ud over en fremhævelse af det - ud fra en subjektiv politisk vurdering - hensigtsmæssige $\mathrm{i}$ dette 'standpunkt'.

Den diskussion, som HJN s. 91-92 fører om, hvorfor »den økonomiske bevægelse og klassebevægelsen « må skildres i ét dokumenterer klart dette forhold: At kapitalen stadig er det herskende produktionsforhold og derfor også »forbyder « os at analysere dens produktions- og klasserelationer i politiske magtkategorier, synes $\mathrm{HJN}$ at have glemt. Tværtimod hopper han let og elegant hen over den nødvendige historisk udviklede modsætning mellem $\emptyset$ konomi og politik, der først og fremmest fremtræder som en adskillelse. For slet ikke at tale om den kampkraft og »proletariatets modmagt«, som han tillægger en arbejderklasse, som $\mathrm{i}$ dag allerhфjst meget sporadisk og det $\mathrm{i}$ form af ganske enkelte arbejdspladsgruppers umiddelbare strejkeberedskab er ved at udvikle elementer af en overskridende udvikling.

I det hele tage etablerer HJN med arbejderstandpunkt en selvmodsigelse, som viser sig at udtrykke det misforhold mellem teorien (kritikken af den politiske $\varnothing$ konomi) og hans historiske forklaringsansatser, som jeg allerede har været inde på: På den ene side anerkender han profitratens tenden tielle fald som immanent bevægelseslov for produktivkraftudviklingen. Samtidig er totalkapitalens gennemsættelse som den regulerende »bagom-ryggen-på-enkeltkapitalerne-ten- dens « tilsyneladende sat ud af kraft med den tredje fase i den »reelle subsumtion«. Den historiske formidlings- 
form er »klasseantagonismen«, »styrkeforholdet mellem klasserne«, kapitalistklassens strategiske »modforholdsregler « $\bmod$ den potentielle »modmagt« osv. Kritikken af den politiske $\varnothing$ konomi bliver i realiteten kun reflekteret formelt: i HJN's egen fremstilling af arbejderstandpunkt findes der således ingen egentlig inddragelse af »de immanente $\varnothing$ konomiske årsager « (s. 117) som fundamentalt kunne adskille den fra Roth's, som HJN trods alt finder går for vidt i sin tillæggelse kapitalistklassen en bevidst planlægning.

Den programmatisk formulerede sandhed, at kritikken af den politiske $\varnothing$ konomi ikke kan danne ensidigt udgangspunkt for historiske bestemmelser af bevidstheden, er altså ikke nogen undskyldning for at fortolke Marx' analyse af den umiddelbare produktionsproces, som om den fremstillede et uformidlet politisk herredømmeforhold.

Det er faktisk, hvad der er tilfældet, når HJN med PF bestemmer produktionsprocessen som vardimassig udbytningsproces og materiel disciplineringsproces. Dette gøres i forsøget på at komplettere kritikken af den politiske $\varnothing$ konomis $\varnothing$ konomiske nødvendighedsbetragtning (værdimæssig udbytningsproces) med en politisk begrundet medreflektion af kapitalernes foranstaltninger til »stabilisering af udbytningsforholdet «. En hurtig genkalden sig Marx’ bestemmelse af den kapitalistiske produktionsproces' dobbeltkarakter som enhed af valoriserings- og arbejdsproces sætter en sådan 'komplettering' i relief. I og med at HJN implanterer en adskillelse mellem valorisering og konkret udbytning og lægger en umiddelbar politisk magtudfoldelse ind i produktionsprocessen, fjerner han rent faktisk klassekampen fra denne umiddelbare produktionsproces. Det lyder paradoksalt - og det er det også! Thi samtidig med, at kapitalens herredømme over det levende arbejde her forstås ensidigt ud fra produktionsprocessens stof- ligtkonkrete side (som 'repressionsform'), placeres akkumulationens udviklingsformer og -dynamik udenfor produktionsprocessen. Det, som nødvendigvis alment betragtet må konstituere den egentlige konfrontation mellem kapital og lønarbejde (og mellem 'kapitalaffirmativitet og -negation'), nemlig kapitalens valoriseringstvang, degraderes her til en i forhold til produktionsprocessen ydre selvbevægende udvikling. Klassekampen kommer herved ikke til at udspille sig indenfor produktionsprocessens konkrete klasemodsætning, men bliver til et post festum foretagende omkring produktionsprocessens resultat. Den modsætningsfyldte proces, hvorigennem kapitalen søger at overskride sine egne skranker, bliver for HJN reelt en gnidningsløs og automatisk størrelse, som tendentielt kun inddrages formelt $\mathrm{i}$ form af subsumtionens »faser og former«, som »værdisiden« eller som noget $»$ konjunkturelt «. De indre forbindelser mellem denne proces og de arbejdskampe, som skulle være 'svaret' herpå, kan derfor ikke fremstilles konkret, når ikke længere den kapitalistiske organisering af produktionen udgør det politiske angrebsfelt. Her bliver i stedet kapitalistklassens strategi sigtepunktet, hvorved politikken mister sit økonomisk satte indhold.

I det omfang HJN inddrager denne kapitalens subsumtionsproces i sin generelle bevidsthedsteoretiske fremstilling reflekteres den tværtimod primært som »kapitalistklassens strategi«. At HJN i sin kritik af PF's »Rationalisierung und Massenarbeiter « bebrejder dem deres overbetoning af de bevidste momenter i denne strategi synes ikke at have større konsekvenser. Den nævnte teoretiske reproduktion af reproduktionsprocessens quasi yderliggjorte fremtrædelse gør det umuligt for HJN at indløse programmet: »kapitalistklassens strategi opsøges i relation til den historiske akkumulationsproces' udvikling«. (s. 108). Tværtimod må 
han springe over, hvor gærdet er lavest, for at berige fremstillingen af »de $\varnothing$ konomiske bevægelseslove « med styrkeforholdsbetragtningen: Kapitalens akkumulation formidles slet og ret af kapitalistklassens strategi. »Parallelt hertil må vi bidrage til analysen af mulighedsbetingelserne for arbejderklassens strategi. En sådan strategi kan ikke som kapitalens strategi have produktionsmådens egen logik på sin side, men i arbejdskampens realitet ligger de bevidsthedsmæssige og organisatoriske muligheder der på længere sigt kan blive revolutionære muligheder.« (s. 88). Såvel kapitalist- som arbejderklassens bevidsthedskonstituering anskues her ensidigt og isoleret indenfor rammerne af de politiskorganisatoriske og magtmassige kampformer (forsvar/angreb). Kapitallogikken som realhistorisk udviklingsdynamik er $\emptyset$ jensynligt ikke virksom, når det drejer sig om den historiske udvikling og/eller om klassernes politiske bevægelse. Med sin fremstilling adskiller HJN sig derfor - trods hans formelle PF-kritik - ikke væsentligt fra PF hvad angår subjektiveringen eller politiseringen af kapital/lønarbejder-forholdet.

Dette får til konsekvens, at produktionsagenternes bevidsthedsudvikling bestemmes indenfor rammerne af politiske kategorier. Den produktionsproces-nære reproduktionskamp forstås ikke blot ensidigt som et klassepraktisk spørgsmål, men »fremstillingsstrategien« udfolder sig som konsekvens heraf reelt som et isoleret bevidsthedsteoretisk afdækningsfors $\varnothing \mathrm{g}$. S. 106-107 nævner HJN 1) arbejdskraftsalget og lønkampens konjunkturelle bestemmelse, 2) staten og de herigennem formidlede kampbetingelser og 3) reproduktionsfeltet: familie, bolig, transport m.v. som de betingelser, der - udover produktionsprocessens dobbeltkarakter må inddrages til bestemmelse af arbejderbevidsthedens konstituering. Det hjælper imidlertid ikke meget, når han reelt ikke tager højde herfor, men istedet erstatter den specifikke historiske diskussion og bestemmelse af disse forhold med en politologisk arbejdskamplogik'. Opmærksomheden rettes ensidigt mod de kampformer, som f.eks. intensiveringens lønformer giver grundlag for både i kapitalist- og i arbejderklassen, mens indholdet af de udførte kampe, de specifikke kampgenstande, som sættes historisk af kapitalens fors $\emptyset \mathrm{g}$ på at overskride sine akkumulationsformer, tendensielt falder udenfor HJN's interessefelt. Denne umådeholdne opprioritering af »klassekampen « og klassernes forsvars- og angrebsformer, er som nævnt s. 129 nok ikke nogen tilfældighed, al den stund HJN's ærinde i bund og grund er bevidsthedsteoretisk. Analyseudgangspunktet centreres om de politiske undertrykkelsesformer (»klasseantagonismens forløb i klassekonflikter«). Nødvendigheden heraf siges at være begrundet materielt (»den konkrete konfrontation mellem arbejde og kapital er afgørende« - PF) men ikke desto mindre får fikseringen til produktionsprocessens stoflige side den konsekvens, at konstitutionssammenhængen begrundes i de forsvarskampe, som denne proces' »materielle disciplineringsproces« sætter. Resultat: krumtappen for såvel den historiske udvikling som for den teoretiske rekonstruktion af denne er og bliver den bevidsthedsmassigt artikulerede kamp og ikke den ellers så højt besungne »historiske produktions- og akkumulationsproces' udvikling« (s. 108).

Denne politisering i sammenhæng med HJN's særlige placering af arbejderklassens politiske »modmagt « som central kategori for bestemmelsen af de kapital-overskridende muligheder implicerer endelig, at kritikken af det kapitalistiske samfund kun kan udfoldes indenfor rammerne af specifikke konkrete undersøgelser (Jvf. s. 88: »Den almene logiske fremstilling peger blot på det historiske subjekt, som er indeholdt i produktionsmådens modsigelser «. Op imod dette må den marxske analyses 
kritik-element fremhæves: Gennem sine bestemmelser af kapitalens modsætningsfyldte underlæggelse fremstiller Marx ikke blot kapitalen som subjekt og arbejdet som »objektgjort«. Afdækningen af kapitalens overskridelse af sine egne skranker fremviser netop forgangeligheden i arbejderklassens »objektgørelse«. Da kapitalforholdet altid forudsættes i sin historiske eksistens, betyder dette, at Marx' fremstilling af kapitalens udviklingsdynamik samtidig er en kritik: Gennem kapitalens historiske subsumtionsbevægelse fremtræder »den historiske betydning af den kapitalistiske produktion (...) slående (specifikt), netop gennem omvæltningen af den umiddelbare produktionsproces selv og udviklingen af arbejdets samfundsmæssige produktivkræfter.« Herved påvises, hvordan »det »samfundsmæssige « osv. ved arbejderens arbejde ikke kun »forestillet«, men også »faktisk « træder over for arbejderen ikke kun som fremmed, men som fjendtligt og modsat, og som genstandsgjort og personificeret i kapitalen.« (Begge steder citeret fra Resultater af den umiddelbare produktionsproces, Modtryk, s. 97, mine understregninger). Arbejderklassen eksisterer hos Marx som subjekt, men ikke som subjektiv kategori!

\section{V}

I det foregående har jeg fors $\emptyset g t$ at vise, hvordan HJN i sit forsøg på at gennemtænke, »hvorledes den videnskabelige fremstilling må være for at den kan have en kritisk potens over for udbytningen af arbejderklassen « (s. 85 ) erstatter kapitalens udviklingslogik med en reelt subjektiv 'arbejdskamp-logik', og hvordan hans abstrakt-teoretiske behandling af bevidsthedsproblemet hænger sammen hermed. Vi har konstateret, at HJN - på trods af sit program om at betragte den $\varnothing$ konomiske og klassemæssige bevægelse i ét - ikke tager arbejderklassens bevidsthedskonstituering op konkret ud fra det kampindhold, som kapitalens historiske udvikling sætter for den eksisterende arbejderbevægelse. Sammenholdes dette nu med HJN's interesse, som i denne sammenhæng primært er erkendelsesmæssig og bevidsthedsteoretisk, kan man ikke forundres over den funktion, han tildeler de marxistiske intellektuelle.

Således tillægges fagkritikken en vurderende funktion overfor arbejderkampene. Det hedder f.eks. at fagkritikken må levere »historiske analyser, som skal opsamle de historiske erfaringer, der udgør arbejderklassens bevidsthed «. Man kunne spørge om intentionen hermed, når samtidig de intellektuelle ikke kan have status af »teoretikerne « i klassekampen? HJN drager øjensynligt ikke konsekvensen af sin egen fremhævelse af bevidsthedskonstitueringen som et »praktisk politisk problem«. Strategien for fagkritikkens opsamlingsarbejde er nemlig ikke bestemt indholdsmæssigt omkring de praktiske modsætninger, som udvikler sig historisk i arbejderklassens kamp. I forhold hertil afgrænses den snarere formsmæssigt ud fra de konsekvenser, som »en begrænset forståelse « for selve organiseringens politiske betydning kunne have. (se f.eks. s. 97). $»$ Fremstillingsstrategien «s problem aktualiseres altså af, at den arbejderklasse, som de intellektuelle står udenfor, har brug for en - teoretisk formidlet - korrekt forståelse af sine kampbetingelser. Hermed bliver de in-

Fortsattes side 174 


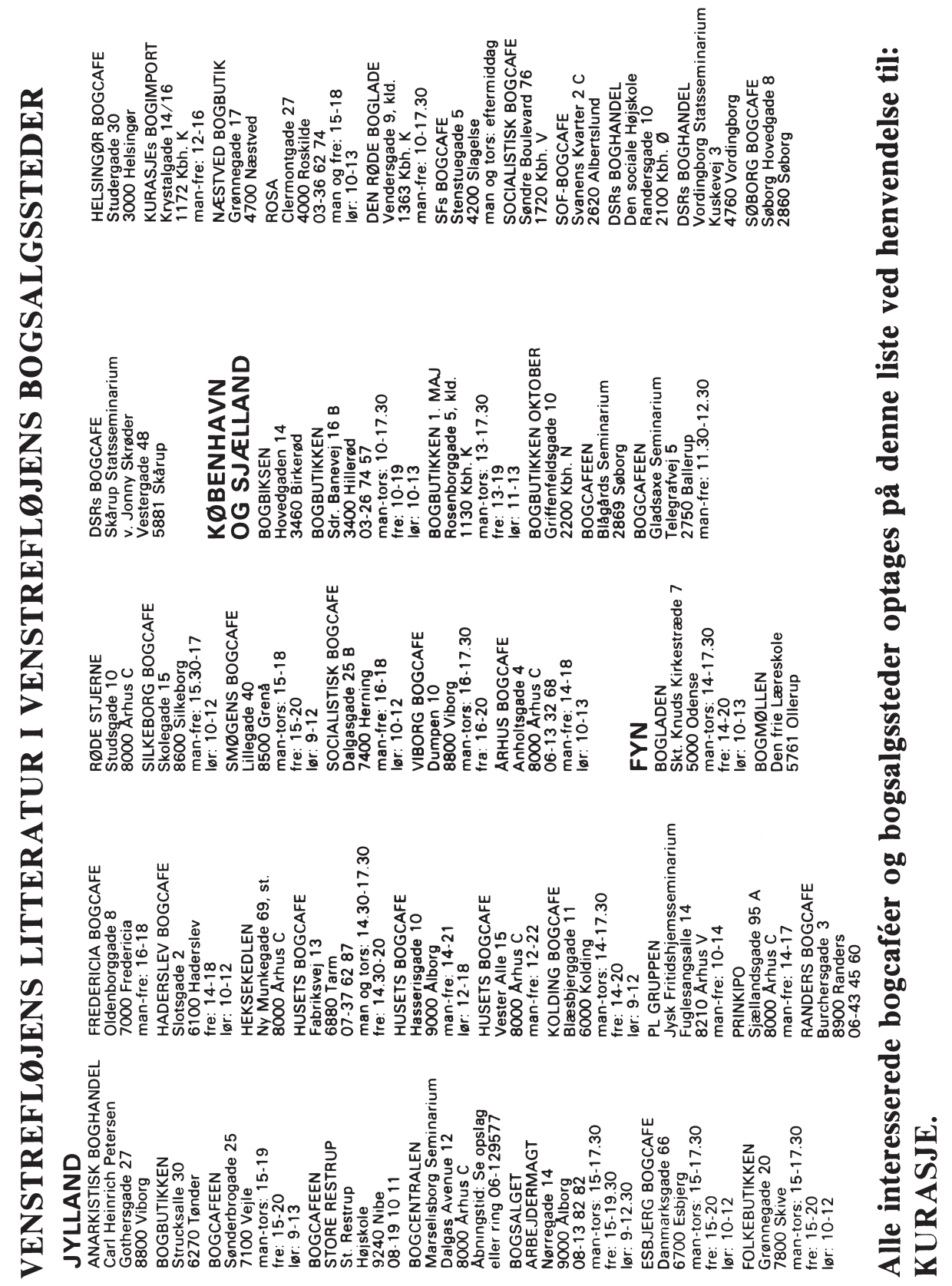




\section{KURASJE}

Adresse:

Giro:

Løssalgspris:

Abonnement:
KURASJE, Krystalgade 16/14, 1172 København K, Danmark

7166044

Nr. 1: udsolgt

Nr. 2-3: udsolgt

Nr. 4: $\quad 10,00 \mathrm{kr}$.

Nr. 5-6: $20,00 \mathrm{kr}$.

Nr. 7: $\quad 12,00 \mathrm{kr}$.

Nr. 8: $\quad 10,00 \mathrm{kr}$.

Nr. 9: $\quad 15,00 \mathrm{kr}$.

Nr. 10: $\quad 15,00 \mathrm{kr}$.

Nr. 11: $16,00 \mathrm{kr}$.

Nr. 12: $25,00 \mathrm{kr}$.

Nr. 13: $30,00 \mathrm{kr}$.

Nr. 14: $30,00 \mathrm{kr}$.

Nr. 1-4: udsolgt

Nr. 5-8: $35,00 \mathrm{kr}$.

Nr. 9-12: $50,00 \mathrm{kr}$.

Nr. 13-16: 60,00 kr.

Bestilling sker ved indbetaling af ét af disse beløb. Anfør på girotalonen, hvad indbetalingen dækker. 